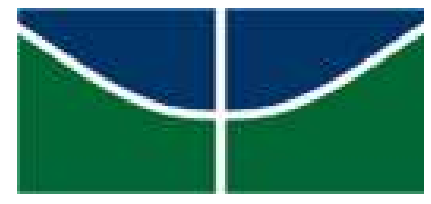

Universidade de Brasília

Faculdade de Economia, Administração, Contabilidade e Ciências da Informação e Documentação - FACE

Departamento de Economia

\title{
Perspectivas Heterodoxas para o Desenvolvimento Produtivo no Brasil Contemporâneo
}

Pedro Garrido da Costa Lima

Brasília

Agosto de 2015 


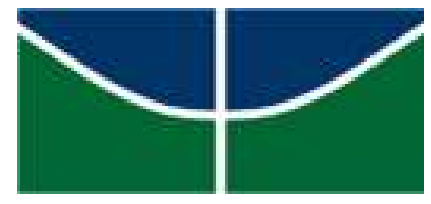

Universidade de Brasília

Faculdade de Economia, Administração, Contabilidade e Ciências da Informação e Documentação - FACE

Departamento de Economia

\section{Perspectivas Heterodoxas para o Desenvolvimento Produtivo no Brasil Contemporâneo}

Pedro Garrido da Costa Lima

Tese apresentada ao Departamento de Economia da Universidade de Brasília, como requisito à obtenção do título de Doutor em Economia.

Orientadora: Adriana Moreira Amado

Brasília

Agosto de 2015 


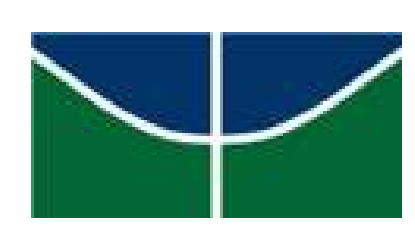

\title{
Perspectivas Heterodoxas para o Desenvolvimento Produtivo no Brasil Contemporâneo
}

\author{
Pedro Garrido da Costa Lima
}

Orientadora: Professora Doutora Adriana Moreira Amado, UnB

Banca Examinadora

Professora Doutora Maria de Lourdes Rollemberg Mollo, UnB

Professora Doutora Andrea Cabello, UnB

Professor Doutor Mariano Francisco Laplane, Unicamp

Doutor Cláudio Roberto Amitrano, IPEA

Suplente: Professor Doutor Roberto de Góes Ellery Júnior, UnB 


\section{LIMA, Pedro Garrido da Costa}

Perspectivas Heterodoxas para o Desenvolvimento Produtivo no Brasil Contemporâneo. Brasília: o autor, 2015.

$225 \mathrm{f}$.

Inclui bibliografia.

Orientação: Profa Adriana Moreira Amado

Tese (Doutorado) - Universidade de Brasília, Departamento de Economia, Pós-Graduação em Economia, 2015. 
"nada começa que não tenha que acabar, tudo o que começa nasce do que acabou (...)"

José Saramago 
Dedico este trabalho a José e Solange. 


\section{Agradecimentos}

Agradeço a diversas pessoas do MDIC que possibilitaram meus estudos para o Doutorado, como Getúlio Valverde de Lacerda, Eduardo Serrano, Alessandro Teixeira, Humberto Ribeiro, Marcelo Maia e Douglas Finardi.

Agradeço aos diversos amigos, com quem pude debater diversas questões, entre os quais Gabriel Borges, Henrique Pissaia, Thális Ryan, Marcelo Teixeira, Thiago Pacheco, André

Rafael Costa e Silva, Francisco Gordillo, Saulo Quadros, Daniela Freddo e Pedro Celso Fonseca.

Agradeço a Solange, pelo apoio da vida inteira.

Agradeço a Marcela e José, pelo apoio ao longo deste projeto e os diversos outros projetos de vida.

Agradeço à equipe administrativa da Pós-Graduação do Departamento de Economia, em especial Joana Farias e Carina Lima.

Agradeço aos Professores Mariano Laplane, Claudio Amitrano e Andrea Cabello, pelas sugestões ao trabalho desenvolvido nesta Tese.

Agradeço à Professora Maria de Lourdes Rollemberg Mollo, pelas discussões sobre desenvolvimento e economia política.

Agradeço à Professora Adriana Moreira Amado, pela orientação, as discussões, a paciência e o incentivo ao longo dos estudos. 


\section{RESUMO}

$\mathrm{Na}$ presente Tese, são apresentados ensaios com discussões sobre perspectivas heterodoxas para o desenvolvimento produtivo no Brasil contemporâneo. São estudados fundamentos macroeconômicos nas perspectivas de Marx e Keynes que fornecem contribuições para a heterodoxia, principalmente quanto à atuação estatal no contexto macroeconômico. A pesquisa sobre elementos da firma, do investimento e da indústria inspirados em Marx e Keynes suscita compreensão de aspectos fundamentais do comportamento das firmas na economia capitalista. Diferentes perspectivas sobre políticas de desenvolvimento produtivo, principalmente heterodoxas, podem somar-se ao debate brasileiro recente e contribuir com a discussão sobre desenvolvimentismo e formas de intervenção na economia. A avaliação de dimensões importantes da inserção internacional e da estrutura interna da economia brasileira enseja o exame de políticas de desenvolvimento produtivo no período recente. Comentários finais sobre os temas abordados são empreendidos na articulação de elementos importantes para a discussão e a formulação de políticas de desenvolvimento produtivo no Brasil contemporâneo.

Palavras-chave: Desenvolvimento produtivo; Heterodoxia; Marx; Keynes; Estruturalismo; Política Industrial; Economia Brasileira. 


\begin{abstract}
This Thesis presents essays with discussions about heterodox perspectives on contemporary productive development in Brazil. Macroeconomic foundations are studied from the perspectives of Marx and Keynes and bring about contributions to heterodoxy, principally regarding the State intervention in the macroeconomic context. The research about elements of the firm, investment and industry inspired by Marx and Keynes elicits understanding about fundamental aspects of firm behaviour in the capitalist economy. Different perspectives on productive development policies, especially heterodox, can be added to the recent Brazilian debate and contribute to the discussion on developmentalism and forms of intervention in the economy. The evaluation of important dimensions of international insertion and the internal structure of the Brazilian economy entails the examination of productive development policies in recent years. Final comments on the subjects covered are undertaken in articulating important elements to the discussion and formulation of productive development policies in contemporary Brazil.
\end{abstract}

Keywords: Productive development; Heterodoxy; Marx; Keynes; Structuralism; Industrial Policy; Brazilian Economy. 


\section{Sumário}

Introdução.

Capítulo 1. Fundamentos macroeconômicos nas perspectivas de Marx e Keynes: contribuições para a heterodoxia

1.1. Introdução 18

1.2. Fundamentos microeconômicos no pensamento dominante e críticas 19

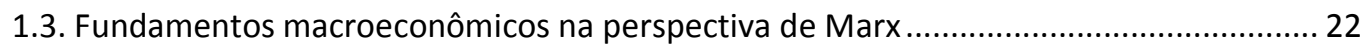

1.4. Fundamentos macroeconômicos na perspectiva de Keynes .................................... 26

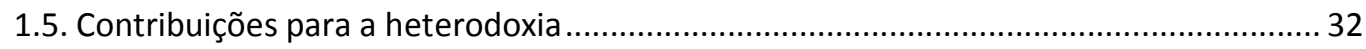

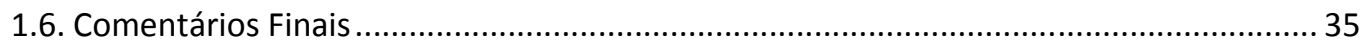

Capítulo 2. Elementos da firma, do investimento e da indústria inspirados em Marx e Keynes 37

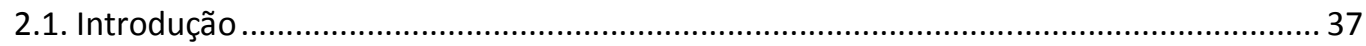

2.2. Noção de firma na nova economia institucional e perspectivas alternativas ................. 38

2.3. Firma e acumulação de capital inspirados em Marx.................................................. 41

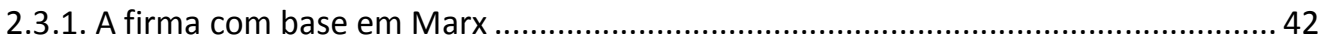

2.3.2. Elementos da acumulação de capital............................................................. 52

2.4. A firma em Keynes e nos Pós-Keynesianos e o papel do investimento nas economias

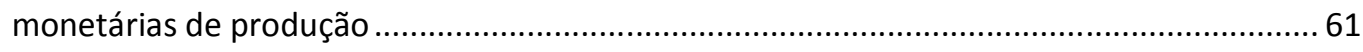

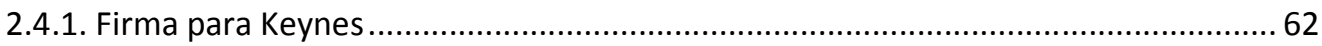

2.4.2. Contribuições pós-keynesianas para teoria da firma ........................................69

2.4.3. Ativos e investimento nas economias monetárias de produção ............................ 78

2.5. Firma, investimento e análise setorial no capitalismo ........................................... 84

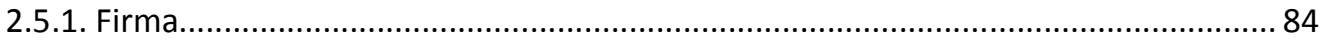

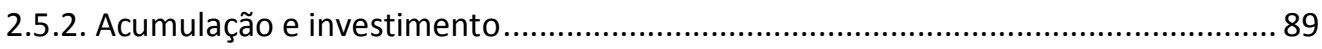

2.5.3. Papel da indústria e distribuição setorial na economia .................................... 92

2.6. Comentários finais......................................................................................... 97

Capítulo 3. Diferentes perspectivas sobre políticas de desenvolvimento produtivo ............... 100

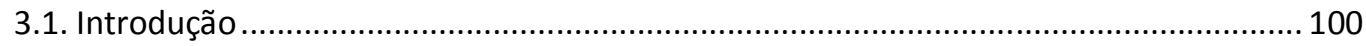

3.2. Políticas industriais e diversificação produtiva na ortodoxia..................................... 101

3.3. Estruturalismo latino-americano e experiências em política industrial ..................... 109

3.3.1. Proposições iniciais sobre política industrial ................................................. 110

3.3.2. Permanência e mudança no pensamento estruturalista recente ........................ 113

3.3.3. Estado como empreendedor e políticas industriais na história......................... 118

3.4. Perspectivas marxistas e keynesianas no desenvolvimento produtivo ....................... 123

3.4.1. Perspectivas marxistas sobre o Estado ....................................................... 123 
3.4.2. Políticas keynesianas

3.4.3. Contribuições com base em Marx e Keynes 139

3.5. Desenvolvimentismo, heterodoxia e políticas industriais no debate brasileiro 140

3.6. Comentários finais. 146

Capítulo 4. Economia brasileira recente e políticas de desenvolvimento produtivo 149

4.1. Introdução 149

4.2. Aspectos da inserção da economia brasileira na economia mundial . 150

4.2.1. Introdução 150

4.2.2. Aspectos da indústria na economia mundial recente. 150

4.2.3. Vulnerabilidade e balança comercial da economia brasileira............................... 156

4.2.4. Mudança estrutural recente no comércio exterior brasileiro ............................. 159

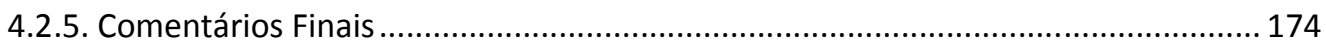

4.3. Mudanças no desenvolvimento produtivo e na indústria ..................................... 174

4.3.1. Introdução ..................................................................................... 174

4.3.2. Elementos das políticas econômicas recentes e o desenvolvimento produtivo no

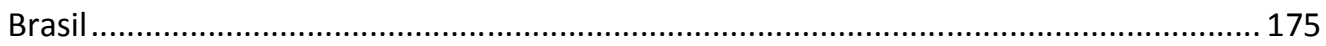

4.3.3. Aspectos da dinâmica recente da indústria ................................................... 186

4.4. Políticas de desenvolvimento produtivo para a economia brasileira ........................... 195

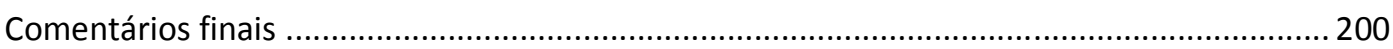

Apêndice. Mudanças recentes na metodologia das Contas Nacionais no Brasil.................... 206

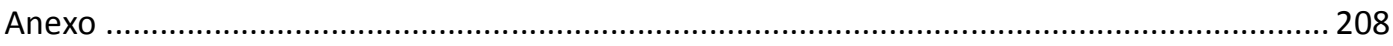

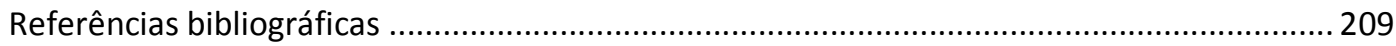




\section{Lista de Gráficos}

Gráfico 1. Participação de grupos de economias e da China no total mundial do valor adicionado na manufatura, 1990-2013.

Gráfico 2. Valor adicionado na manufatura e participação no valor adicionado na manufatura mundial, países selecionados, 1990-2013.

Gráfico 3. Valor adicionado na manufatura e participação no valor adicionado na manufatura, economia brasileira, 1990-2013. 153 Gráfico 4. Balanço de Pagamentos brasileiro: contas das transações correntes, 1995-2014, US\$ milhões. 157

Gráfico 5. Balanço de Pagamentos brasileiro: transações correntes e conta capital e financeira, 1995-2014, US\$ milhões. 158

Gráfico 6. Exportações e importações brasileiras totais, preços correntes e constantes de 2006, 1996-2014. 164

Gráfico 7. Balança comercial, preços correntes e constantes de 2006, 1996-2014. 164 Gráfico 8. Contribuição ao saldo comercial, setores selecionados com melhora no desempenho, 1996-2014. 167

Gráfico 9. Contribuição ao saldo comercial, setores selecionados com piora no desempenho, 1996-2014. 168

Gráfico 10. Contribuição ao saldo comercial, setores selecionados com piora no desempenho, 1996-2014. 168

Gráfico 11. Balança comercial por intensidade tecnológica, valores normalizados, 1996-2014.

Gráfico 12. Participação das exportações por intensidade tecnológica no total, 2005 e 2014. 172

Gráfico 13. Participação das importações por intensidade tecnológica no total, 2005 e 2014. 173

Gráfico 14. Participação da remuneração dos empregados no PIB, 1995-2011. 178

Gráfico 15. Renda domiciliar média per capita (R\$ de outubro de 2013) e coeficiente de Gini, 1995-2013.

Gráfico 16. Participação da formação bruta de capital fixo no PIB, preços correntes, 1996-2014.

Gráfico 17. Participação da indústria de transformação no PIB, preços correntes, 1996-2014.187 Gráfico 18. Taxa de crescimento anual do valor adicionado, série encadeada apreços constantes, 1996-2014. 187

Gráfico 19. Relação entre valor de transformação industrial e valor bruto da produção, 19962013. 188

Gráfico 20. Coeficiente de exportação e coeficiente de penetração de importações na indústria de transformação, 1996-2014. 189 Gráfico 21. Evolução da rentabilidade das indústrias extrativas e de transformação, 1996-2013.

Gráfico 22. Evolução da taxa de investimento na indústria de transformação, 1996-2013 ...... 190

Gráfico 23. Gastos de pessoal como proporção dos custos e despesas totais, 1996-2013......... 193 Gráfico 24. Índice de custos de compensações (salários diretos e indiretos) da mão de obra por hora como percentual dos custos dos EUA, países selecionados, 1996-2013. 194 Gráfico 25. Participação da Formação Bruta de Capital Fixo no PIB segundo o SCN-2000 e o SCN-2010, 2000-2011. 207 


\section{Lista de Tabelas}

Tabela 1. Participação de segmentos de média e alta tecnologia no PIB industrial e nas exportações industriais e das exportações industriais nas exportações totais, 1990, 2002 e 2012.

Tabela 2. Balança comercial setorial normalizada, percentuais por setor CNAE 2.0 a preços constantes de 2006, anos selecionados. 165

Tabela 3. Índice de Mudança Estrutural, períodos selecionados, setores CNAE 2.0. 170

Tabela 4. Participação percentual do investimento nas indústrias de transformação e extrativa, 2007-2013. 192

Tabela 5. Diferenças na composição setorial entre o SCN-2010 e o SCN-2000, por atividades, 2010

Tabela 6. Classificação setorial por intensidade tecnológica. 208

\section{Lista de abreviações}

ABDI - Agência Brasileira de Desenvolvimento Industrial

Abimaq - Associação Brasileira da Indústria de Máquinas e Equipamentos

BCB - Banco Central do Brasil

BNDES - Banco Nacional de Desenvolvimento Econômico e Social

Cepal - Comissão Econômica para a América Latina e o Caribe

CLT - Consolidação das Leis do Trabalho

CNI - Confederação Nacional da Indústria

CNDI - Conselho Nacional de Desenvolvimento Industrial

CNT - Contas Nacionais Trimestrais

FBCF - Formação Bruta de Capital Fixo

FMI - Fundo Monetário Internacional

Funcex - Fundação Centro de Estudos do Comércio Exterior

IED - Investimento Estrangeiro Direto

IBGE - Instituto Brasileiro de Geografia e Estatística

IPEA - Instituto de Pesquisa Econômica Aplicada

MDIC - Ministério do Desenvolvimento, Indústria e Comércio Exterior

MEI - Mobilização Empresarial pela Inovação

OCDE - Organização para a Cooperação e Desenvolvimento Econômico

OMC - Organização Mundial do Comércio

PIA-Empresa - Pesquisa Industrial Anual-Empresa

Pintec - Pesquisa de Inovação Tecnológica

PITCE - Política industrial, Tecnológica e de Comércio Exterior

PBM - Plano Brasil Maior

PDP - Política de Desenvolvimento Produtivo 
PNAD - Pesquisa Nacional por Amostra de Domicílios

SCN - Sistema de Contas Nacionais

Secex/MDIC - Secretaria de Comércio Exterior do MDIC

SNA - System of National Accounts

UNIDO - United Nations Industrial Development Organization 


\section{Introdução}

O desenvolvimento econômico constitui campo de estudos no qual existe significativo debate sobre motivos, justificativas, teorias e ações práticas para as políticas públicas. O desenvolvimento produtivo é importante para as escolas heterodoxas, sendo essenciais as práticas, em alguma medida, de políticas industriais ou de desenvolvimento

produtivo. É possível destacar diversas contribuições relevantes, principalmente no campo da heterodoxia, para o estudo do desenvolvimento produtivo na economia brasileira recente.

Além desta breve introdução, a presente Tese foi dividida em quatro capítulos e comentários finais. Os capítulos representam ensaios que tratam de elementos teóricos e empíricos considerados centrais em algumas perspectivas heterodoxas no desenvolvimento produtivo, em especial no caso da economia brasileira recente. São abordados temas como fundamentos macroeconômicos em Marx e Keynes, elementos da firma, do investimento e da indústria inspirados em Marx e Keynes, diferentes perspectivas sobre políticas de desenvolvimento produtivo e a economia brasileira recente e políticas de desenvolvimento produtivo. Os comentários feitos ao final da Tese articulam alguns dos elementos que foram tratados ao longo do trabalho, especialmente no que diz respeito à formulação de políticas de desenvolvimento produtivo na economia brasileira.

No capítulo 1, são discutidos fundamentos macroeconômicos nas perspectivas de Marx e Keynes e feitas contribuições para a heterodoxia. A partir de discussão inicial de fundamentos microeconômicos no pensamento dominante e de algumas críticas a essa abordagem, são apresentados fundamentos macroeconômicos na perspectiva de Marx e na perspectiva de Keynes. São discutidas e comentadas as contribuições desses dois últimos autores para a heterodoxia, principalmente quanto à possibilidade de atuação no contexto macroeconômico.

No capítulo 2, são avaliados elementos da firma, do investimento e da indústria em Marx e Keynes. É realizada apresentação inicial da noção de firma na nova economia institucional e em perspectivas alternativas. Passa-se à discussão da firma e da acumulação de capital em Marx. Em seguida, são examinados a firma em Keynes e nos 
Pós-Keynesianos e o papel do investimento nas economias monetárias de produção, tratando em particular da firma para Keynes, das contribuições pós-keynesianas para teoria da firma e da noção de ativos e investimento nas economias monetárias de produção. Após discutir os dois autores, são avaliadas conjuntamente as noções deles sobre firma, investimento e análise setorial no capitalismo e feitos comentários finais sobre esses assuntos.

No capítulo 3, diferentes perspectivas sobre políticas de desenvolvimento produtivo são abordadas. Avaliam-se as políticas industriais e a diversificação produtiva na ortodoxia inicialmente, fazendo-se avaliação crítica de contribuições recentes. Em seguida, são examinados o estruturalismo latino-americano e algumas experiências em política industrial. Em particular, são relevantes as proposições sobre política industrial na Cepal, a permanência e mudança no pensamento estruturalista recente e as noções sobre o Estado como empreendedor e sobre políticas industriais na história. Na sequência, perspectivas marxistas e keynesianas no desenvolvimento produtivo são discutidas, particularmente determinadas contribuições marxistas sobre o Estado e noções sobre políticas keynesianas. Em seguida, são discutidos desenvolvimentismo, heterodoxia e políticas industriais no debate brasileiro. Ao final do capítulo são feitos comentários sobre a discussão apresentada.

No capítulo 4, examinam-se a economia brasileira recente e políticas de desenvolvimento produtivo, com observação da evolução recente de alguns dados empíricos. São observados aspectos da inserção da economia brasileira na economia mundial, com relação à indústria na economia mundial recente, à vulnerabilidade e balança comercial da economia brasileira e à mudança estrutural recente no comércio exterior brasileiro. Em seguida, mudanças no desenvolvimento produtivo e na indústria são discutidas, para notar traços importantes das políticas econômicas recentes e do desenvolvimento produtivo no Brasil. Na sequência, são examinados aspectos da dinâmica recente da indústria e feitos comentários sobre políticas de desenvolvimento produtivo para a economia brasileira.

A discussão realizada pode trazer elementos teóricos e empíricos significativos em articulação com o debate sobre desenvolvimento econômico e social brasileiro recente. A avaliação sobre distintas perspectivas de desenvolvimentismo e de justificativas e motivações para a atuação estatal, no contexto complexo do capitalismo particular brasileiro, pode constituir contribuição relevante à formulação de políticas e ao 
entendimento dos desafios existentes para o desenvolvimento produtivo no Brasil contemporâneo. 


\section{Capítulo 1. Fundamentos macroeconômicos nas perspectivas de Marx e Keynes: contribuições para a heterodoxia}

\subsection{Introdução}

O pensamento dominante na economia contemporânea tem como agenda de pesquisa o desenvolvimento de modelos com base em fundamentos microeconômicos para a análise de aspectos macroeconômicos na economia. Essa necessidade pode ser questionada com base em desenvolvimentos próprios da economia mainstream. É possível cogitar, ademais, a formulação de fundamentos macroeconômicos para o comportamento microeconômico dos agentes na economia.

As contribuições teóricas de Marx e Keynes podem ser consideradas significativas para a formulação de fundamentos macroeconômicos e para o entendimento das ações e motivações no sistema econômico capitalista. Elementos essenciais das duas perspectivas, como as relações sociais que permeiam o capitalismo, a incerteza e as convenções, presentes em trabalhos originais de Marx e Keynes e em outros autores, permitem a busca de outras formas de teorização econômica sobre as ações dos agentes na economia. Dessa forma, para entender o comportamento de agentes econômicos e grupos sociais, torna-se essencial compreender os fundamentos sociais e macroeconômicos delimitadores das ações nas sociedades capitalistas.

Além dessa introdução, o presente capítulo tem a seguinte estrutura. São apresentados, na seção 1, os fundamentos microeconômicos no mainstream e algumas críticas a esses fundamentos. Na seção 2, são analisados os fundamentos macroeconômicos na perspectiva de Marx. Os fundamentos macroeconômicos conforme Keynes são discutidos na seção 3. As contribuições das perspectivas marxista e póskeynesiana para a heterodoxia são avaliadas na seção 4. Por fim, são apresentados comentários finais sobre os assuntos discutidos. 


\subsection{Fundamentos microeconômicos no pensamento dominante e críticas}

A visão predominante na economia ortodoxa quanto aos fundamentos microeconômicos relaciona o surgimento desse programa de pesquisa e método para construção de modelos teóricos com a conhecida crítica feita por Lucas (1976) aos modelos macroeconométricos. Nessa perspectiva, que passa a ser influente junto com a escola novo clássica e a utilização generalizada de expectativas racionais, procuram-se microfundamentos para a teoria macroeconômica, buscando-se parâmetros profundos decorrentes do comportamento de otimização individual dos agentes econômicos. A determinação do resultado agregado pela incorporação de microfundamentos definidos pelo comportamento otimizador de agentes individuais racionais geraria a necessidade de desenvolver modelos com agentes representativos ${ }^{1}$. Essa visão tornou-se dominante na ortodoxia e foi adotada pelas escolas de ciclos reais e novo-keynesiana.

A narrativa padrão sobre os microfundamentos na teoria econômica pode ser reconsiderada com base na história do pensamento econômico, segundo Duarte e Lima (2012), para quem essa narrativa serve para sustentar um argumento metodológico que é historicamente particular. Essa forma de relacionar as interações micro e macroeconômicas não é a única, nem a primeira a ser proposta. Essa perspectiva também está sujeita a dificuldades associadas à agregação. O teorema de Sonnenschein-MantelDebreu do início dos anos 1970 já mostrava que as restrições que geram funções de demanda individuais bem-comportadas não levam a funções de demanda agregadas com essas mesmas propriedades. Para evitar esse problema, ou se supõe uma economia composta de indivíduos idênticos ou um agente que represente toda a economia ${ }^{2}$, solução esta seguida pela ortodoxia.

Apesar dessa opção metodológica, Hoover (2012) distingue, na literatura econômica a partir do início do século XX, dois outros programas de pesquisa com base em microfundamentos (o de agregação para modelos macroeconométricos de Klein e o

\footnotetext{
${ }^{1}$ Cabe distinguir o contexto da utilização de agentes representativos na macroeconomia da maneira como essa noção surge na microeconomia. De acordo com Screpanti e Zamagni (2005), Marshall teve grande influência na teoria econômica a partir do uso do método de equilíbrio parcial em que utilizava os conceitos de indústria e de firma representativa. A indústria produziria bens iguais, enquanto a firma representativa denotaria uma firma média que reproduzia as características mais importantes da indústria.

${ }^{2}$ A metodologia de agentes representativos domina as outras abordagens de microfundamentos, no entanto, trabalha apenas com o comportamento único desse agente hipotético. Essa metodologia, ao não levar em conta a heterogeneidade entre agentes, desconsidera problemas de coordenação.
} 
de equilíbrio geral avançado por Hicks) além do programa que se utiliza do conceito de agente representativo. Ele considera alguns autores importantes que se encontram na préhistória dessa abordagem (Frisch e Keynes). Com base nessa reconstrução histórica, explica-se que o programa de pesquisa do agente representativo incorpora "eliminative microfoundations", em que se busca suprimir a macroeconomia em benefício da microeconomia. Já os outros dois programas de pesquisa, que eram formas alternativas dentro da perspectiva ortodoxa, não implicavam necessariamente essa eliminação. Kirman (1992) argumenta em favor da impossibilidade de redução do comportamento de um grupo de agentes heterogêneos a um indivíduo representativo, mesmo que esses agentes sejam maximizadores de utilidade. A suposta conveniência analítica do agente representativo é injustificada e leva a resultados falsos, sem resolver problemas de agregação. A busca por equilíbrio único e estável levou os macroeconomistas a adotarem o agente representativo para tentar desviar da dificuldade advinda do teorema de Sonnenschein-Mantel-Debreu ${ }^{3}$. Ainda assim, mesmo que essa dificuldade seja desconsiderada, Kirman nota que a maximização individual não gera racionalidade coletiva, nem a existência dessa racionalidade implica indivíduos racionais. Também a reação do agente representativo a mudanças em parâmetros (como as causadas por políticas governamentais) pode não ser igual à reação agregada dos indivíduos representados por esse agente. Podem ainda existir situações em que o agente representativo escolheria diferentemente de todos os indivíduos representados. Dessa forma, "to infer society's preferences from those of the representative individual, and to use these to make policy choices, is illegitimate." Kirman (1992, p. 125) aponta que:

(...) the assumption of a representative individual is far from innocent; it is the fiction by which macroeconomics can justify equilibrium analysis and provide pseudomicrofoundations.

Além das dificuldades associadas a agregação e heterogeneidade, a sinalização proveniente das variáveis macroeconômicas para os indivíduos permite questionar os microfundamentos presentes na ortodoxia e conferir relevo à necessidade de fundamentos macroeconômicos. Nesse sentido, Hahn (2003) critica a noção de agentes representativos na macroeconomia e indica, utilizando a lógica de otimização dos agentes econômicos, como é necessário discutir macrofundamentos para o estudo da microeconomia, com

\footnotetext{
${ }^{3}$ Kirman (1992) salienta que a agregação de indivíduos bem-comportados, que têm curva de demanda com equilíbrio único e estável, não necessariamente reproduz essas propriedades. $\mathrm{O}$ axioma fraco da preferência revelada não é obedecido nessa agregação.
} 
destaque para a situação de busca no mercado de trabalho e a sinalização proveniente dos índices de preços. Para Hahn (2003, p. 230):

macro-variables act as measures of particular externalities and so must be considered by micro theory. (...) changes in the values of macro variables may lead to structural changes in the [General Equilibrium] description of an economy.

Assim, as variáveis macroeconômicas são sinais para os agentes, quando não se tem informação perfeita para realizar previsões corretas do mercado no longo prazo. O agente não pode observar todos os preços na economia e formar expectativas sobre o valor futuro de cada preço.

O reconhecimento de que a microeconomia e a macroeconomia são constituídas por metodologias e campos teóricos separados, mas com importantes inter-relações, foi apontado por autores como Bresser-Pereira e Lima (1996), para quem a macroeconomia não pode ser reduzida à microeconomia. Essa abordagem associa o método históricoindutivo à primeira disciplina e o hipotético-dedutivo à segunda, o que não limita o pensamento macro a ser deduzido de ações individuais. Ademais, identidades macroeconômicas são consistentes com diversos comportamentos micro definidos $a d$ hoc. Defendem os autores que a maximização individual e o market-clearing da teoria neoclássica constituem caso específico de microfundamentação. A fundamentação micro pode ser derivada, mais amplamente, de hipóteses associadas ao comportamento de classes e grupos e da concorrência imperfeita, sem maximização ou equilíbrio ${ }^{4}$.

De fato, o caráter discutível dos microfundamentos da macroeconomia torna-se mais claro com a consideração da natureza do sistema capitalista que pode ser derivada das formulações de Marx e Keynes. Esses autores desenvolveram contribuições significativas para a heterodoxia no pensamento econômico, de acordo com Mollo (2003) e Amado (1992), em especial quanto à não neutralidade e endogeneidade da moeda. As concepções de Marx e de Keynes possibilitam contestar a pertinência de fundamentação microeconômica e propiciam base para a fundamentação macroeconômica do comportamento microeconômico nas economias capitalistas.

\footnotetext{
${ }^{4}$ Nesse sentido, Bresser-Pereira e Lima (1996) mencionam as abordagens clássica-marxista e póskeynesiana.
} 


\subsection{Fundamentos macroeconômicos na perspectiva de Marx}

Para Marx, o capitalismo constitui sistema produtor de mercadorias em que se busca incessantemente o lucro máximo pela produção de mais-valia. A riqueza é definida por imensa acumulação de mercadorias. Todos são compradores e vendedores e o valortrabalho e o dinheiro passam a ser relações fundamentais na organização social do capitalismo.

Marx (1857/58) tem como ponto de partida teórico os indivíduos produzindo em sociedade e a totalidade ${ }^{5}$ no sistema capitalista ${ }^{6}$. A produção é entendida como certo corpo social, um sujeito social em atividade em uma totalidade maior ou menor de ramos de produção, em que ocorre apropriação da natureza pelo indivíduo dentro de e mediada por determinada forma de sociedade.

Nesse sentido, Lukács (1984) destaca que Marx, mesmo conferindo prioridade ontológica à esfera econômica, considera a sociedade como um complexo composto por rede de complexos heterogêneos e parciais, entre os quais classes sociais, grupos e sistemas de mediação relativamente autônomos (como direito e Estado). As ações singulares, a consciência e seus conteúdos não são concebidos como produto imediato da estrutura econômica, mas da totalidade social, incluindo as determinações extraeconômicas. Indivíduos reagem com decisões alternativas ao próprio mundo circundante, que constitui a base de todos os complexos de mediação e diferenciação. Quando as relações econômicas são compreendidas como totalidade dinâmica e concreta, evidencia-se que homens fazem sua própria história, mas os resultados do decurso histórico são diversos e podem ser opostos aos objetivos visados pelos inelimináveis atos de vontade dos indivíduos.

Entender um modo de produção, para Marx, requer a apreensão da forma como os homens se organizam para prover sua existência, o que leva ao processo de trabalho. Este, no capitalismo, produz mercadorias. A mercadoria apresenta duas dimensões

\footnotetext{
${ }^{5}$ Cabe notar que o conceito de totalidade, ressalta Jay (1984), foi recuperado e enfatizado pelo marxismo ocidental no debate teórico e prático, com origem em Lukács. Seja com inspiração hegeliana ou antihegeliana, conceitos como alienação, mediação, objetificação e reificação, assim como o papel da cultura, foram importantes elementos de discussão entre os autores associados a essa tradição.

${ }^{6} \mathrm{Na}$ Introdução à Crítica da Economia Política, Marx (1857/58), por meio do método dialético, explica que, ao se partir da totalidade e chegar de novo a ela após abstrações por meio do pensamento, é obtida rica totalidade de determinações e relações diversas, e não uma representação caótica do todo. A realidade concreta pensada passa a ser uma "síntese de múltiplas determinações".
} 
correspondentes a dois tipos de trabalho diferentes. O trabalho concreto confere utilidade própria às mercadorias, que satisfazem as necessidades "do estômago e da fantasia" na condição de valor de uso. A propriedade comum a todas as mercadorias é a de ser produto do trabalho humano abstrato. Sob esta dimensão não existe um único átomo de valor-deuso nelas, não há qualquer trabalho útil. O trabalho despendido e cristalizado em cada mercadoria é a medida socialmente necessária para a produção daquele bem. $\mathrm{O}$ valor-detroca revela-se na relação quantitativa entre valores-de-uso diferentes, nas suas proporções de troca no tempo. O que vai importar é a quantidade de tempo de trabalho social contido determinando a magnitude do valor da mercadoria ${ }^{7}$.

A troca direta não pode existir se cada mercadoria for valor e valor de uso ao mesmo tempo. Essa contradição pode ser evitada se algo representar, em geral, o valor de todas as outras mercadorias. Assim, as mercadorias podem ser valores de uso elas mesmas e valores quando confrontadas com uma única mercadoria, que passa a ter como valor de uso a explicitação do valor de troca. A interação espontânea entre as mercadorias isola uma de seu conjunto, excluindo-a da circulação das outras mercadorias para tornar-se a representante independente do valor. Apenas a ação social de todas as outras mercadorias elege, portanto, uma determinada para nela representarem seus valores (Brunhoff, 1976, e Saad Filho, 2002).

Nas sociedades capitalistas, dado seu caráter mercantil, os trabalhos são privados mas precisam ser divididos socialmente, o que é feito por meio da venda contra dinheiro. Nesse processo, trabalhos privados são socialmente validados. Assim, a característica do sistema produtor de mercadorias é que valor e dinheiro são relações sociais e determinam a forma de inserção social no capitalismo ${ }^{8}$. Como todos os indivíduos são compradores e vendedores de mercadorias, a divisão do trabalho é feita por meio do valor e do dinheiro. Dessa forma, os trabalhadores, após processo histórico de subsunção real e formal do trabalho, passam a não ter outro para viver em sociedade a não ser o de ofertar sua força de trabalho como mercadoria para os capitalistas. Como esta classe detém os meios de produção e paga aos trabalhadores o valor equivalente ao custo de reprodução da força de trabalho, os capitalistas podem apropriar-se do trabalho ou valor excedente produzido

\footnotetext{
${ }^{7}$ A partir da consideração desse caráter dual do trabalho na mercadoria, Postone (1993) destaca que podem ser distinguidas duas totalidades sociais expressas pela categoria do capital, a abstrata formal e a substantiva, que representam, respectivamente, as duas formas de trabalho expressas na mercadoria, abstrato e concreto.

${ }^{8}$ Para Itoh e Lapavitsas (1999), o dinheiro é relação social que define, de maneira alienada, a inserção social dos indivíduos como nexus rerum (o elemento que une) do capitalismo.
} 
pelos trabalhadores. Assim, o sistema é produtor de mais-valia, ao gerar lucro pela exploração do trabalho excedente ${ }^{9}$.

Observe-se que, nesta visão, o trabalho e o valor que o contém, assim como o dinheiro que o representa, são formas sociais fundamentais de organização da sociedade e das ações dos indivíduos. Sobre a importância do trabalho, diz Postone (2008, p. 128), “(...) the Marxian contradiction should be understood as a growing contradiction between the sort of labour people perform under capitalism and the sort of labour they could perform if value were abolished and the productive potential developed under capitalism were reflexively used to liberate people from the sway of the alienated structures constituted by their own labour". Sobre a importância do dinheiro, diz Marx (1857/58), de forma crítica, que os homens alienam suas próprias decisões a "uma coisa", tornando-a uma relação social.

Nesse processo de produção e circulação, o valor e o dinheiro resolvem a contradição privado-social de uma sociedade onde os trabalhos são realizados de forma privada, e via divisão social, sem que se elimine essa contradição, articulando produção e circulação por meio da realização da divisão social do trabalho de forma indireta. Assim, valor e dinheiro tornam-se relações sociais segundo as quais o dinheiro é excluído socialmente para cumprir o papel de equivalente geral e o critério de validação social dos trabalhos privados é a conversão em dinheiro. Esse teste é feito por meio do dinheiro, mas se dará conforme possibilidade ou não de venda a determinado preço.

Em Marx, vão ser observados dois tipos de circulação do dinheiro (D). A forma simples, em que o objetivo da troca é o valor de uso proporcionado por uma mercadoria $(\mathrm{M})$ :

$$
M-D-M
$$

A circulação do capital tem como objetivo o valor de troca aumentado. O capital é o dinheiro que se valoriza e fundamenta o objetivo microeconômico de lucro incessante das firmas. Embora sejam mantidos equivalentes nas trocas, verifica-se a geração de excedente na apropriação de mais-valia ${ }^{10}$ quando o dinheiro vira capital. A valorização

\footnotetext{
${ }^{9}$ Cabe notar que os valores trocados são equivalentes, então não se trata de roubo ou trocas a valores diminuídos. Assim, de um ponto de vista macroeconômico, ressalta Bellofiore (2004), as trocas não geram valor, apenas o redistribuem.

${ }^{10}$ Uma sociedade cujo objetivo essencial é a troca de produtos por produtos entre indivíduos isolados não corresponde à natureza do capitalismo. Como afirmou Marx (1857/58, p. 54), o "caçador e o pescador, singulares e isolados, pelos quais começam Smith e Ricardo, pertencem às ilusões desprovidas de fantasia das robisonadas do século XVIII".
} 
do capital é o que mantém o capitalista enquanto tal. Assim, é a lógica macroeconômica do capitalismo enquanto modo de produção que forma o comportamento do capitalista:

$$
D-M-D^{\prime}
$$

Sendo D' maior do que D. A expansão dessa fórmula revela o conteúdo presente na circulação do capital $^{11}$, na qual o dinheiro avançado compra as mercadorias força de trabalho (FT) e meios de produção (MP), as quais são utilizadas no processo de produção (P) que gera mercadorias com mais valor (M') do que o inicial, quando convertido em dinheiro (D'):

$$
D-M\left\{\begin{array}{l}
F T \\
M P
\end{array} \ldots P \quad \ldots M^{\prime}-D^{\prime}\right.
$$

Os conceitos definidos por Marx suscitam a avaliação de que pode existir autonomia relativa da esfera da circulação em relação à produção. O desenvolvimento do crédito e do capital fictício, no processo de financeirização e descolamento do lastro em trabalho, constitui exemplo dessa autonomização do capital em busca de maior lucro e menos limites, como estuda Mollo (2011). Não obstante, a relativa autonomia entre preço e valor e entre circulação e produção é limitada pela lei do valor. As mercadorias precisam ser convertidas em dinheiro para provar a validade social do trabalho privado dispendido e realizar assim a divisão social do trabalho. Mas a lei do valor pode também se impor de maneira violenta, por meio de crises, que são fenômenos inerentes ao capitalismo.

Dessa forma, a determinação social do trabalho por meio da relação de valor consubstancia-se, de um ponto de vista social e econômico, como exigência sobre o comportamento dos indivíduos no capitalismo.

A dinâmica na esfera da produção não é menos sujeita a condicionantes macroeconômicos à ação dos agentes e enseja trajetórias de crises. Em razão da busca por lucro, objetivo do capitalismo, e superlucro, sob pressão da concorrência intercapitalista, há tendência a aumentar a mais-valia absoluta e, principalmente, a relativa, para o que se impõe a necessidade de investimento em desenvolvimento tecnológico que amplie a produtividade dos trabalhadores e reduza os custos, em particular o de reprodução da força de trabalho. Revela-se aí o caráter excludente do capitalismo por meio da concentração e centralização de capitais e do aumento do desemprego, ao qual está

\footnotetext{
${ }^{11}$ Essa circulação ainda está associada ao capital-dinheiro e o crédito, este que potencializa o processo produtivo, além do capital mercantil, que possibilita a venda de mercadorias aos consumidores finais, conforme Marx $(1885,1894)$.
} 
associado o exército industrial de reserva ${ }^{12}$. A mais-valia relativa decorre do progresso tecnológico, o qual, reduzindo custos, particularmente o de reprodução da força de trabalho, permite aumentar o lucro. No entanto, esse investimento é caro, o que conduz à concentração e centralização do capital. O progresso técnico é poupador de mão de obra, levando ao desemprego. O aumento da produção não é acompanhado pela capacidade de consumo. Ocorre, portanto, caso em que o comportamento individual de capitalistas, fruto da lógica do sistema ao buscar maior lucro em meio ao processo de concorrência, é contraditório com relação ao desenvolvimento sustentado do sistema.

Nesse sentido, o ambiente macroeconômico constitui-se, para Marx, como maior do que a soma de suas partes constituintes, de acordo com Bellofiore (2004). Os resultados macro podem ser não apenas anteriores, apresentando-se como responsáveis pelo comportamento micro das classes, mas também opostos aos interesses e comportamento micro. A precedência e autonomia da lógica macroeconômica significa que a pesquisa precisa primeiramente descobrir as leis de sobrevivência e crescimento do sistema e depois mostrar como o comportamento dos indivíduos obedece ou contradiz essas leis. A originalidade de Marx está na fundamentação macrossocial dos comportamentos.

Nessa perspectiva macrossocial, a produção de mais-valia aparece em Marx de maneira explicitamente macroeconômica. A extração de trabalho vivo e, portanto, de trabalho abstrato, caracteriza-se como processo macro incorporado no contexto maior das relações capital/trabalho, uma vez que a luta de classes entre a totalidade da classe trabalhadora e a totalidade da classe capitalista determina a intensidade do processo produtivo e a duração da jornada de trabalho. Apenas a partir dessa consideração macro é que se torna possível entender a constituição da renda monetária total como resultado do trabalho abstrato

\subsection{Fundamentos macroeconômicos na perspectiva de Keynes}

\footnotetext{
${ }^{12} \mathrm{O}$ exército industrial de reserva impõe freios ao crescimento dos salários e disciplina os trabalhadores em razão do medo de ficar desempregado.
} 
É possível evidenciar fundamentos macroeconômicos para a ação dos agentes individuais a partir de características da sociedade capitalista na concepção mais heterodoxa de Keynes e dos pós-keynesianos. A operação dos agentes em uma economia monetária de produção que é inerentemente incerta pressupõe a emergência de convenções e de determinada psicologia social nas quais estão ancoradas as expectativas e o comportamento dos agentes.

A perspectiva de Keynes (1936), na Teoria Geral, constitui exemplo, segundo Dow (1996), de abordagem holística em que é empreendida combinação logicamente consistente entre análise micro e macro, ainda que os microfundamentos não sejam exatamente equivalentes aos da teoria neoclássica. Keynes utilizou fundamentos microeconômicos próximos à visão neoclássica, para combater essa abordagem em seu próprio terreno, mostrando a inadequação da Lei de Say mesmo com fundamentos neoclássicos, conforme ressalta Chick (1983). Também as contribuições teóricas de autores pós-keynesianos para o entendimento das relações entre os aspectos micro e macroeconômicos das economias capitalistas remontam ao artigo de Weintraub (1956), em que são encontradas referências explícitas a microfundamentos em período anterior mesmo à preocupação da ortodoxia novo clássica.

A preocupação com o comportamento humano em sociedade e a lógica das ações dentro deste contexto social marcam a base do pensamento econômico descrito por Keynes (1937), ao elaborar explicitamente as concepções que haviam sido avançadas na Teoria Geral (1936). O autor começa a sua análise econômica a partir da ênfase na lógica do comportamento humano em um mundo onde nada está muito definido. Os agentes econômicos não são autômatos e decidem e agem segundo a vida em uma sociedade cuja trajetória é indeterminada. As razões para a existência da moeda decorrem de uma necessidade real na sociedade econômica que não diz respeito somente à circulação.

A teoria neoclássica parte de um mundo que pode ser descrito de acordo com algum cálculo atuarial, eliminando-se a incerteza, pois o mundo seria definido conforme determinadas funções de probabilidade. Essa interpretação dos princípios do comportamento dos agentes na economia torna-se equivocada ao subestimar o papel da dúvida e do medo na sociedade. Segundo Keynes, a teoria (neo)clássica desconsidera a diferença que a sua abstração provoca entre a teoria e a prática e o caráter das falácias para as quais ela é levada, mesmo admitindo, eventualmente, a precariedade do conhecimento. Assim, Keynes (1937, p. 115) assevera: 
I accuse the classical economy theory of being one of these pretty, polite techniques which tries to deal with the present by abstracting from the fact that we know very little about the future.

A preocupação com o comportamento humano em sociedade e a lógica das ações dentro deste contexto social marcam a base do pensamento econômico de Keynes. De fato, "...we have, as a rule, only the vaguest idea of any but the most direct consequences of our acts." Algumas vezes a preocupação é com um futuro remoto; e entre as principais angústias humanas relacionadas a esses momentos está a questão econômica central da riqueza. O objetivo da acumulação de riqueza é produzir resultados num futuro indefinidamente distante, em uma atividade contínua e incessante. A constatação de que o futuro é flutuante, vago e incerto torna inadequados os métodos da teoria clássica ${ }^{13}$.

A noção de conhecimento incerto é essencial para o entendimento da teoria de Keynes e não significa distinção entre o que é certo ou apenas provável. Os fenômenos sociais (como guerras, preços futuros, uso de tecnologia ou alocação de riqueza) não apresentam base científica para o cálculo de probabilidades. Não há como prever com certeza: "We simply do not know". Mesmo assim, a impulsão para a ação e decisão leva os indivíduos a atuarem da melhor maneira possível para passar por cima desses problemas, recorrendo ao cálculo de vantagens e desvantagens esperadas, segundo probabilidades atribuídas. Ou seja, ainda que o mundo acabe sendo descrito em termos de probabilidades pelos agentes, esta base para atuação é muito fraca e representa maneira de lidar com a incerteza, mas não uma qualidade do próprio mundo.

A racionalidade, dada essa condição da economia, requer a constituição de convenções, de acordo com Keynes. Configura-se, dessa maneira, uma resposta racional dos seres humanos ("rational, economic men") face à incerteza. As técnicas desenvolvidas para lidar com a incerteza são: 1) o presente é um guia melhor para o futuro do que um cândido exame da experiência passada, em que são ignoradas as projeções sobre mudanças futuras desconhecidas; 2) a opinião sobre preços e o caráter da produção existentes são baseados no resumo correto de previsões futuras, devendo-se aceitá-las como tal a não ser que haja novidades relevantes; e 3) como julgamento individual é irrelevante, os indivíduos agem copiando o comportamento majoritário ou mediano. A psicologia de uma sociedade de indivíduos onde cada um procura copiar os outros leva a julgamento chamado convencional. Esses princípios sobre o comportamento humano

\footnotetext{
${ }^{13} \mathrm{Se}$, no mundo capitalista, a acumulação não constituísse uma característica fundamental e os bens fossem consumidos imediatamente depois de produzidos, aqueles métodos seriam aplicáveis.
} 
também atuam quando há mudanças repentinas e violentas, que podem trazer nova base de convenções.

A moeda surge como necessidade do mundo econômico para fazer frente à incerteza. Por isso, ocupa as funções de unidade de conta, meio de circulação (ou troca) e reserva de valor. Essas funções estão intimamente associadas na concepção de Keynes. Sendo reserva de valor, a moeda não possui rendimento, e parece irracional mantê-lo (1937, p. 115-16):

Why should anyone outside a lunatic asylum wish to use money as a store of wealth? (...) partly on reasonable and partly on instinctive grounds, our desire to hold money as a store of wealth is a barometer of the degree of our distrust of our own calculations and conventions concerning the future. (....) The possession of actual money lulls our disquietude; and the premium which we require to make us part with money is the measure of the degree of our disquietude.

Assim, a principal decorrência das flutuações no estado de confiança da economia é a variação do prêmio concedido para os agentes abrirem mão de entesourar moeda. Este prêmio é a taxa de juros, que varia conforme a preferência pela liquidez ou propensão a entesourar e ajusta, na margem, a demanda e a oferta de entesouramento. A taxa de juros em Keynes é um fenômeno monetário, não um equilíbrio entre poupança e investimento como na teoria neoclássica dos fundos emprestáveis. As flutuações no investimento não estão relacionadas à disposição de poupar determinada renda ou de condições técnicas da eficiência marginal do capital.

Em uma economia monetária, a moeda não é apenas um meio de circulação, mas também um ativo, um meio de conservar riqueza, sendo seu principal atributo a capacidade de liquidar débitos e representar poder de compra em sua forma mais pura. É capaz de desempenhar esta função por ser o ativo mais líquido da economia. A função unidade de conta merece destaque, pois os contratos na economia são firmados em termos monetários. O dinheiro é mantido também para fazer uma ponte entre intervalos definidos entre transações monetárias como representação de riqueza, um ativo que pode ser guardado para ser gasto em alguma data futura. A existência da demanda por dinheiro como ativo afeta a demanda e os preços de outros ativos, que são formas alternativas de conservar riqueza com diferentes atributos, sendo determinante para o investimento a escolha entre ativos líquidos (como moeda e títulos financeiros) e bens de capital ${ }^{14}$.

\footnotetext{
${ }^{14}$ Keynes (1936, capítulo 17) fornece interpretação da escolha sobre o emprego da riqueza, ao elaborar, como ressaltam Chick (1983) e Carvalho (1992), uma teoria de escolha de ativos pela comparação da moeda, definindo a condição de ativo da moeda perante os outros na economia. Em equilíbrio, os
} 
A partir dessa visão de mundo, de acordo com Davidson (1972), Keynes rejeita três axiomas da teoria neoclássica que não correspondem à realidade das economias monetárias. São rejeitados o axioma da substituição (tudo pode ser substituído por outra coisa em algum grau), o axioma dos reais (toda atividade econômica é motivada e conduzida olhando-se variáveis reais, desconsiderando a moeda) e o axioma da ergodicidade (processos econômicos podem ser repetidos, replicados e revertidos). A observação da incerteza implica um mundo indeterminado. $O$ dinheiro não tem substitutos e toda avaliação do valor é feita por meio de preços, que são monetários, o que descarta o pensamento real em qualquer mercado (como o de bens, o monetário e o de trabalho).

Esses condicionantes das economias monetárias influenciam a necessidade de considerar que o ambiente macroeconômico é determinante nas escolhas individuais. De acordo com Kregel (1987, p. 528) ${ }^{15}$ :

The 'non-ergodicity' of the system then ultimately results from the fact that individual actions are constrained by the actions of other individuals which cannot be predicted with certainty and thus when taken together form an aggregate or global or macroeconomic constraint which is not the simple, linear, and therefore predictable summation of individual behaviour. Thus is it not macroeconomics that has to be brought into close touch with microeconomics, but rather one must try to formulate a macrofoundation for uncertain individual decisions.

Carvalho (1992) defende que a abordagem dos pós-keynesianos está ancorada nessa interpretação fundamental dos textos de Keynes e define seis princípios das economias monetárias de produção, que seriam características do capitalismo para essa escola. São os princípios da produção, da estratégia dominante, da temporalidade da atividade econômica, da não-ergodicidade, da coordenação e das propriedades da moeda. Esses princípios fornecem fundamentos, no contexto da incerteza e do comportamento convencional, às ações dos agentes econômicos.

Cabe destacar, no princípio da produção, que a firma tem uma individualidade particular como agente econômico, e difere em objetivos com relação a outros agentes, como as famílias. O princípio da produção estabelece que esta é realizada pelas firmas

rendimentos esperados (taxas de retorno e de apreciação, deduzidos os custos de carregamento) a serem obtidos pelos proprietários dos ativos (não-monetários) devem ser iguais à sua liquidez relativa quando comparados à moeda, de modo a igualar as vantagens marginais entre os ativos.

${ }^{15}$ Kregel (1987) argumenta que os fundamentos macroeconômicos para os comportamentos individuais resultam do papel da moeda e da incerteza fundamental na economia. 
com o propósito de se obter lucros. A firma não existe para fornecer utilidade ao empreendedor (entrepreneur) ou fabricar produtos para serem vendidos e garantirem outros produtos úteis; pois, de fato, o que se busca no capitalismo é a geração continuada e ampliada de lucro, de maneira semelhante ao considerado por Marx ${ }^{16}$.

O princípio da estratégia dominante admite a existência de poderes diferenciados dos agentes na dinâmica econômica. Os mercados de trabalho e poupança dependem das deliberações das firmas. Trabalhadores e poupadores se adaptam aos efeitos das decisões tomadas pelas empresas. Por outro lado, Keynes também enfatizou que o processo de investimento é dominado pelos bancos. A distribuição dos recursos produtivos é desigual entre os agentes. O controle de meios de produção não é acessível a todos, o que determina hierarquias patentes. Isto se deve para Keynes, principalmente, porque o capital é escasso em relação ao trabalho (ainda que durante booms o trabalho escasseie). Entretanto, a capacidade de ter acesso a recursos é a característica mais fundamental: firmas (ou capitalistas) podem dispor de crédito dos bancos e têm mais riqueza acumulada, o que as possibilita comandar mais riqueza na sociedade.

A noção de temporalidade da atividade econômica é outro princípio fundamental. As escalas de produção são decididas baseadas nas expectativas de demanda, pois a produção leva tempo. Durante o processo produtivo, os fatores produtivos são remunerados em dinheiro, que pode ser gasto em qualquer momento posterior. As firmas operam conjecturando sobre a demanda, fazendo com que a produção no capitalismo seja altamente especulativa.

O princípio da não-ergodicidade está associado à proposição de Davidson (1972) de que Keynes rejeita o axioma da ergodicidade, um dos pilares da economia ortodoxa. A incerteza fundamental (não-distribucional) implica a irreversibilidade do tempo e a inadequação da noção de tempo mecânico da teoria neoclássica. O tempo é histórico. Já as propriedades da moeda fazem dela o ativo mais líquido da economia e um ativo imprescindível para afetar os humores e decisões na economia. A moeda possui três propriedades, descritas por Keynes (1936): elasticidades de produção e substituição nulas e custo de carregamento zero.

O princípio da coordenação supõe que, dada a ausência de planos préestabelecidos, a avaliação das atividades produtivas só pode ser obtida ex post-facto, pela revelação do mercado, ou pelo resultado líquido agregado das decisões decentralizadas.

${ }^{16}$ Como reconhece Keynes (1933), ao examinar a validade do circuito de circulação do capital, D-M-D', descrito por Marx. 
Essa visão pós-keynesiana mostra como a incerteza, um fato macroeconômico, afeta as decisões individuais microeconômicas, em particular a decisão de investir. É também a incerteza que leva, por exemplo, a decisões individuais convencionais e imitativas.

\subsection{Contribuições para a heterodoxia}

As abordagens de Marx e de Keynes, em especial nas formulações apresentadas anteriormente, mostram uma alternativa à metodologia do mainstream de derivar os fenômenos macro dos comportamentos microeconômicos. Ao fazer isso lançam luz sobre características essenciais do sistema econômico capitalista.

O método desses autores já se distancia do cartesianismo da escola neoclássica, conforme apresenta Dow (1996). Chick (2003) destaca o organicismo presente em Keynes, em razão de o autor considerar o sistema econômico como um todo orgânico. Já Marx (1857/58), com base no pensamento dialético, utiliza concepção associada à totalidade na análise econômica. Nessa visão total ou orgânica, o estudo dos fenômenos econômicos não pode prescindir da análise histórica, o que está associado essencialmente à heterodoxia, conforme Bresser-Pereira $(2012)^{17}$.

De acordo com Dow (1996) e Howard e King (2001), ambas as formulações refutam o individualismo metodológico e o reducionismo da economia neoclássica. As contradições entre comportamento individual e os resultados agregados nas duas abordagens contrastam com os modelos que reduzem as perspectivas macroeconômicas a agentes representativos microfundamentados que funcionam em perfeito equilíbrio e coordenação, abstraindo até mesmo dos obstáculos à agregação de indivíduos já registrados pela pesquisa em equilíbrio geral. Existe, consequentemente, a possibilidade de falácia da composição e contradições a partir do comportamento dos agentes, o que explicita o caráter instável da economia capitalista observado na realidade. Ademais, o indivíduo não é considerado como unidade de análise apropriada, uma vez que a teoria é

\footnotetext{
${ }^{17}$ Bresser-Pereira (2012) aponta que os neoclássicos seguem o método hipotético-dedutivo, que é fundado em abstrações teóricas sem aplicação prática e não pode ser demonstrado histórica ou empiricamente. Já autores como Marx e Keynes integram grupo de economistas que se utilizaram do método históricodedutivo, com arcabouços teóricos criados, de maneira aberta, pela observação de regularidades e tendências historicamente.
} 
construída a partir de grupos ou categorias de agentes, no caso dos pós-keynesianos e a partir de classes sociais para os marxistas.

Com relação, por exemplo, às firmas na economia capitalista, notam-se interpretações mais voltadas à realidade da concorrência capitalista, em contraposição à visão neoclássica. Os autores pós-keynesianos, argumenta Lavoie (2014), enfatizam o caráter oligopolizado das economias modernas, considerando a definição de mark-up como regra de formação de preços, em ambiente de incerteza. Já Marx (1894) mostra que a concorrência leva à centralização e concentração em razão do imperativo no nível microeconômico, para cada capital individual, da acumulação de capital em geral e do desenvolvimento tecnológico.

O papel da moeda nas economias capitalistas torna-se fundamental para as ações dos agentes econômicos, ao invés de ser um véu sobre as transações reais, justamente porque, mesmo de forma conflituosa e podendo conduzir a instabilidade e crises, é ela que articula e coordena o andamento da economia. A moeda não é neutra, nem no curto nem no longo prazo, e é endógena na economia. Os dois autores, assim, refutam a Lei de Say e a Teoria Quantitativa da Moeda, como destaca Mollo (2003). Tanto para Marx quanto para Keynes a moeda é um fenômeno social que une os indivíduos na sociedade capitalista. A divisão social do trabalho implica a validação social do trabalho privado somente pelo dinheiro, para os marxistas, ao mesmo tempo em que o crédito é indissociável do processo de acumulação, influenciando a natureza própria do capitalismo. Em Keynes, a moeda decorre da necessidade que surge da incerteza e das funções que exerce, e pode acalmar ou não os agentes, influenciando a preferência pela liquidez na economia, variável essencial que, por seu turno, estabelece, junto com a eficiência marginal do capital, o nível de investimento na economia ${ }^{18}$. A moeda, nas duas perspectivas, não pode ser neutra, pois é um bem desejado, sem que isso signifique ilusão monetária, uma vez que a forma dinheiro ou moeda é a expressão de riqueza universal e poder de compra puro, diferentemente de bens particulares ou riquezas específicas em determinados usos.

O papel do Estado na economia é visto como relevante para as duas abordagens. O papel das políticas fiscal e monetária e do Estado no crescimento pode ser ativo, sem que os efeitos dessas políticas sejam neutralizados com o tempo, como defendem autores

\footnotetext{
${ }^{18}$ Em razão do tempo histórico e da incerteza, o investimento, causa causans da determinação do nível de demanda efetiva segundo Keynes (1936), pode acabar restringido, gerando limites monetários ao crescimento, como aponta Amado (2000).
} 
neoclássicos, em razão dos supostos efeitos do crowding-out e da Teoria Quantitativa da Moeda, conforme ressaltam Mollo e Fonseca (2013).

Mollo (2001) observa que os marxistas ${ }^{19}$ reconhecem o Estado como Estado de classe. Ele é ator importante do sistema capitalista, principalmente na regulação estatal de duas mercadorias essenciais, a força de trabalho e o dinheiro. Apesar de ser um Estado de classe, ainda assim, a partir de argumentos desenvolvidos por Poulantzas, é possível verificar certa autonomia do Estado frente às classes sociais, o que pode constituir oportunidade para os trabalhadores pressionarem por melhorias no bem-estar e regulação para melhorar a situação do emprego e do crescimento da economia e de sua inserção social. Mesmo apontando as limitações do Estado burguês, que atua para salvar a economia cuja lógica pune os trabalhadores e não tem como superar definitivamente as crises que surgem da dinâmica econômica, os marxistas admitem que as possibilidades abertas com a melhoria das condições de vida e do emprego permitem contexto mais adequado para barganhas salariais e desenvolvimento de ações coletivas.

Davidson (1991) salienta que os pós-keynesianos defendem papel pronunciado do Estado para a estabilização e o crescimento na economia. O governo pode ter visão mais ampla sobre as necessidades da comunidade, enquanto agentes privados são mais motivados por oportunidade de lucro rápido. O governo é importante na determinação da escala das operações de investimento de longo prazo com benefícios sociais acima das perspectivas de lucro privado, atuando, portanto, na ausência de incentivos privados. Keynes (1936) argumentava em favor da socialização do investimento promovida pelo governo, para assegurar aproximação ao pleno emprego. Embora não observem os limites à atuação estatal previstos pelos marxistas, os pós-keynesianos ressaltam que o papel do governo é criar um ambiente que reduza fortemente os defeitos do sistema econômico sem eliminar suas vantagens

Partindo de uma noção de que o ambiente socioeconômico precede e interfere nos comportamentos econômicos dos agentes, o Estado pode ter um papel na gestão desse ambiente, por meio de políticas econômicas. Com efeito, a formação de um ambiente macroeconômico adequado torna-se necessária para o desenvolvimento econômico. Para isso, o Estado tem papel fundamental para a heterodoxia. Mollo e Teixeira (2008) argumentam, utilizando influências heterodoxas que incluem Marx e Keynes, que as

${ }^{19}$ De acordo com Mollo (2001), dentro dos debates entre os marxistas, existem correntes que não veem possibilidade de melhoria por meio da atuação via Estado, com base na contribuição de Miliband, para quem o Estado é mero braço da burguesia. 
capacidades macrodinâmicas são fundamentais. A ênfase da literatura sobre capacidades dinâmicas recai frequentemente sobre a análise microeconômica, mas a promoção de mudanças estruturais requer uma perspectiva macroeconômica, em que um contexto macrodinâmico apropriado ao progresso econômico e social exerce influência decisiva. Os autores (2008, p. 267) destacam

the importance of a macroeconomic and institutional foundation linking investment, technology and the macro-management of the economy. Prosperity cannot be regarded as natural and expected as a matter of course. Nor can it be characterized by an afflux of new technology, business organization, financial flows, or whatever, unless institutional environment and historical conditions are proper.

Seja para melhor gerir as condições de incerteza, no caso keynesiano, ou para melhorar a inserção social dos trabalhadores na relação capital-trabalho, no caso marxista, algumas linhas de política econômica podem, como sugerido por Mollo e Teixeira (2008), ser buscadas para a sustentação de ambiente que se coadune aos fundamentos macroeconômicos verificados nas economias capitalistas. São relevantes uma estrutura adequada de juros reais para estimular o investimento; uma estrutura de orçamento sustentável sem dívida excessiva, com reestruturação da dívida pública sem pressionar a taxa de juros; uma taxa de câmbio competitiva; um Banco Central com foco na estabilidade financeira, mas também na produção e no emprego; controle prudencial do sistema bancário para evitar fragilidade financeira; e regulação estatal para inibir a supremacia financeira sobre a produção. Também a criação de condições institucionais de demanda, regulação e aprendizado propicia capacidades macrodinâmicas importantes no sistema econômico. Nesse sentido, são apontados a prioridade ao crescimento com melhor distribuição de renda e riqueza; geração de empregos para absorver mão de obra qualificada e menos qualificada do exército industrial de reserva; criação de sistema de seguridade de massa; reforma do sistema tributário para reduzir incidência de impostos sobre classes de menor renda; e estratégias de longo prazo para financiar projetos de investimento públicos, principalmente em infraestrutura, saúde, educação e P\&D.

\subsection{Comentários Finais}


Os fundamentos microeconômicos na abordagem ortodoxa podem ser revistos com base em argumentos presentes até na escola neoclássica. No entanto, os conceitos e a formulação teórica trazidos por Marx e Keynes elucidam aspectos essenciais do sistema capitalista que tornam necessário o entendimento de fundamentos macroeconômicos para o comportamento microeconômico. As abordagens marxista e pós-keynesiana definem o papel e o comportamento dos agentes econômicos a partir de um contexto macro, respectivamente, a evolução capitalista fundada na lei do valor ou permeado pela incerteza que permeia as decisões econômicas em economias monetárias. Essas abordagens heterodoxas permitem compreensão mais ampla da complexidade existente no capitalismo.

As noções avançadas por Marx e Keynes são úteis ao entendimento das limitações ao desenvolvimento econômico no capitalismo e à avaliação da pertinência de políticas econômicas conducentes ao crescimento ou que mitiguem os efeitos da instabilidade e da desigualdade inerentes ao sistema. Diferentemente da perspectiva neoclássica, que não admite intervenções estatais ou as delimita a momentos de estabilização de curto prazo, as duas correntes heterodoxas reconhecem possibilidades de atuação concreta do Estado no desenvolvimento, em particular para agir sobre o contexto macroeconômico que afeta o comportamento dos agentes. 


\section{Capítulo 2. Elementos da firma, do investimento e da indústria inspirados em Marx e Keynes}

\subsection{Introdução}

$\mathrm{O}$ ambiente macroeconômico torna-se fundamental para o desenvolvimento econômico também quanto ao papel da atuação estatal na estrutura produtiva. As relações entre a macroeconomia e as ações dos agentes tornam-se mais claras com a compreensão dos limites e instabilidades existentes no capitalismo. Outrossim, o entendimento sobre as características das ações dos agentes econômicos ganha novo relevo com base em outros fundamentos.

Alguns elementos teóricos com base em Marx e Keynes destacam-se na justificativa teórica do comportamento das firmas, incluindo as relações na esfera produtiva e financeira quanto ao investimento e à reprodução ampliada nas economias capitalistas. Esses elementos distinguem-se de algumas noções influentes na nova economia institucional. Os conceitos derivados de Marx e Keynes são importantes para definições da natureza da firma e da acumulação em meio à desigualdade e incerteza. Tornam-se relevantes diversos aspectos do investimento e a preocupação com a composição setorial da economia.

Além desta introdução, o capítulo divide-se em seções que tratam de discussão teórica sobre aspectos fundamentais para a noção de firma e do investimento e da composição setorial da economia inspirados em Marx e Keynes e formulações com fundação nesses autores. Inicialmente, discorre-se brevemente sobre a noção da firma na nova economia institucional e algumas críticas a essa perspectiva. Na seção 2.3, são examinados o conceito de firma em Marx e os elementos da acumulação de capital com base nessa perspectiva. Na seção 2.4, são discutidos a firma em Keynes, nos póskeynesianos e o papel do investimento no contexto das economias monetárias de produção. A seção 2.5 articula elementos da firma, do investimento e da análise setorial no capitalismo com fundamento nas contribuições de Marx e Keynes estudada. Por fim, são feitos comentários finais à discussão apresentada. 


\subsection{Noção de firma na nova economia institucional e perspectivas alternativas}

A nova economia institucional tem desenvolvido explicação influente para uma renovada teoria da firma na perspectiva ortodoxa. A noção de custos de transação permitiu à teoria neoclássica explicar a possibilidade teórica da firma no capitalismo, a partir das contribuições como as de Coase (1937) e Williamson (1985, 2002). Para além de funções e fatores de produção nas explicações tradicionais marginalistas, essa perspectiva enfatiza a organização, a governança, os contratos e os direitos de propriedade a partir das transações na economia ${ }^{20}$.

Para Coase (1937), os mercados e as firmas são modos alternativos de coordenação na alocação de recursos, em que a firma suplanta o mecanismo de mercado por meio do comando sobre os recursos na economia. A alocação por meio do planejamento ou comando, em contraste com a utilização direta do mercado, está associada ao fato de que o uso do mecanismo de preços relativos tem custos. São gastos recursos para descobrir os preços relevantes via processo de negociação e estabelecimento de comportamento contratual. O comando, pelo qual uma parte segue a direção de outra, diminui a necessidade de contínuas e custosas renegociações e reformulações de contratos. As instituições econômicas, como a firma, economizam recursos no que respeita aos custos de contratar via mercado, embora não os eliminem.

Williamson $(1985,2002)$ denominou custo de transação esse dispêndio de recursos para realizar trocas e, por meio desse conceito e de outros, tornou-se um dos expoentes da chamada nova economia institucional. Para Williamson, deve ser feita reconceitualizaçao da firma como estrutura de governança, não como função de produção como na "science of choice tradition". A unidade de análise é a transação, enquanto os agentes apresentam racionalidade limitada frente a contratos limitados e oportunismo. As transações são planejadas para economizar frente aos custos de conhecimento e computação associados à racionalidade limitada e para proteger as transações do oportunismo dos agentes. De acordo com Williamson (2002, p .174, grifos no original), o estudo da governança "also appeals to bounded rationality, but the main lesson for the science of contract is different: All complex contracts are unavoidably incomplete".

\footnotetext{
${ }^{20}$ Para Coriat e Weinstein (2010), de Coase a Williamson, passando por Alchian e Demsetz, a concepção contratual da firma apresenta-se hoje como a nova ortodoxia sobre o tema.
} 
As principais dimensões por meio das quais as transações se diferenciam para Williamson são a especificidade, a incerteza e a frequência. A maior especificidade dos ativos e a maior frequência com que as transações devem acontecer são determinantes para a escolha de integrar as transações à estrutura da firma. A racionalidade limitada se refere na realidade à incompletude dos contratos e à ocorrência de comportamento oportunista dos agentes, já que os contratos não podem prever todas as possibilidades e os agentes podem encontrar meios de obter vantagens sobre os outros.

A escolha entre modos distintos de contratação tem como critério a economia de custos de transação, bem como a avaliação das diferenças entre custos de transação envolve comparação institucional. Assim, a verificação de custos relativos a especificidade de ativos, racionalidade limitada e oportunismo explicam a integração vertical e o surgimento de modos de organização hierárquicos como a firma. As firmas, para Williamson, são compreendidas como unidades administrativas ou hierarquias, ao invés de unidades de produção, identificadas com determinadas funções de produção, como na teoria marginalista convencional. Assim, a produção por meio da integração vertical das operações não se desenrola por motivos tecnológicos, mas sim por necessidade associada à governança. A "science of contracts" proposta não indica oposição entre hierarquias e mercados, mas sim pretende analisar as situações em que é preferido um ao outro.

Apesar da influência sobre a visão dominante em Economia, a perspectiva dos custos de transação não está isenta de críticas. Hodgson (1998) contesta essa teoria contratual da firma e avalia que o ímpeto para o desenvolvimento de teoria da firma baseada em competências advém da insatisfação com a explicação exclusiva pelos custos de transação ou com os argumentos calcados na lógica desses custos. Hodgson identifica três problemas presentes na visão contratualista. As transações entre indivíduos atomísticos maximizadores com preferências independentes são o ponto de partida analítico, o que negligencia os limites dos contratos e das trocas e das relações não contratuais. A análise da firma é reduzida a contratos entre indivíduos, com preocupação apenas na escolha de governança, minimização de custos de transação e eficiência alocativa, o que retira ênfase da produção, da acumulação e do crescimento e separa produção e tecnologia das estruturas de governança ou custos de transação. Existe também foco maior em explicações baseadas em estática comparativa, principalmente pela comparação dos custos de transação entre diferentes arranjos organizacionais, 
levando a tratamento inadequado dos aspectos dinâmicos como aprendizado, inovação e desenvolvimento tecnológico.

O distanciamento frente à consideração da esfera da produção parece constituir elemento limitador da visão dominante quanto à firma. Dunn (2002) reavalia a noção de custos de transação e reconhece que a abordagem contratual sustenta preocupação excessiva com mercados e trocas, negligenciando a principal atividade das firmas, que é a organização e a execução da produção. De fato, argumenta Williamson (1985, p. 87) que "in the beginning there were markets".

Chandler (1992) também discorda da concepção de que as transações sejam a unidade de análise. Para o autor, a firma, com seus ativos físicos e humanos, deve ser a unidade de análise, sendo definida como um conjunto de capacidades organizacionais. A especificidade dos ativos continua significativa, mas a natureza da estrutura física e das habilidades ou capacidades é mais importante do que a racionalidade limitada e o oportunismo para moldar as decisões de internalizar transações, em especial no longo prazo, e determinar os limites entre a firma e o mercado.

As decisões da firma na perspectiva contratual parecem mais voltadas para a escolha das transações a integrar à organização do que as decisões estratégicas e o aprendizado das firmas. Mesmo que Williamson se contraponha à denominada tradição da escolha e tenha como referência a racionalidade limitada de Simon (1957), os fundamentos neoclássicos relacionados à teoria da agência e direitos de propriedade são predominantes na abordagem contratual, conforme Coriat e Weinstein (2010), faltando abordar a gestão das informações, a criação e gestão dos conhecimentos e habilidades e a gestão dos conflitos de interesse. Também Simon (1991), do ponto de vista a teoria das organizações entende como incompleta a nova economia institucional e nota a falta mecanismos organizacionais como autoridade, identificação e coordenação, em benefício da explicação com base nos conceitos de agência, informação imperfeita, custos de transação e oportunismo da economia neoclássica.

Entre as noções alternativas da firma podem ser buscadas contribuições teóricas inspiradas em Marx e Keynes. Além de constituir contraponto à visão dos custos de transação, podem ser notadas contribuições para o entendimento ampliado da natureza da firma no sistema capitalista ou economia monetária de produção. Aspectos importantes da acumulação e do investimento nesses autores revelam características significativas do comportamento das firmas. 


\subsection{Firma e acumulação de capital inspirados em Marx}

Nesta seção, são discutidos elementos centrais da firma e da acumulação de capital no capitalismo inspirados em conceitos originados na obra de Marx. O modo de produção capitalista, para Marx, constitui totalidade complexa em que diferentes esferas da realidade devem ser analisadas, a produção, distribuição, troca e consumo. A partir dessa perspectiva, existe uma predominância da produção, em decorrência da forma como é gerado o excedente na economia, sem que os outros momentos percam sua unidade dialética ou deixem de ter importância e interação entre si e com a esfera produtiva. Nos Grundrisse, Marx (1857/58, p. 75-76, grifos no original) assevera que:

O resultado a que chegamos não é que produção, distribuição, troca e consumo são idênticos, mas que todos eles são membros de uma totalidade, diferenças dentro de uma unidade. A produção estende-se tanto para além de si mesma na determinação antitética da produção, como sobrepõe-se sobre os outros momentos. É a partir dela que o processo sempre recomeça. (...) Uma produção determinada, portanto, determina um consumo, uma troca e uma distribuição determinados, bem como relações determinadas desses diferentes momentos entre si. A produção, por sua vez, certamente é também determinada, em sua forma unilateral, pelos outros momentos. (...) Há uma interação entre os diferentes momentos. Esse é o caso em qualquer todo orgânico.

Nesse todo orgânico, é possível destacar elementos relacionados ao conceito de firma que constituem base importante para a compreensão do capitalismo contemporâneo. Marx, no Livro I de O Capital (1867), pretendeu analisar o processo de produção do capital. Na Parte 4, sobre a produção de mais-valia relativa, é tratada a gênese da forma verdadeiramente capitalista da organização do trabalho, que passa a ser subsumido ao capital. O Livro II de O Capital (1885) discute mais detidamente o processo de circulação do capital e revela como a firma se comporta no capitalismo em diversos aspectos, em especial quanto ao capital produtivo. Já no Livro III (1894), sobre o processo global de produção capitalista, são tratados aspectos da concorrência e das finanças que influenciam o comportamento no capitalismo.

É possível notar conjunto de autores que tomaram Marx como referência para tratar de comportamentos individuais em Economia e outras áreas das Ciências Sociais e desenvolveram formulações para contestar o materialismo dialético na obra de Marx. Utilizando diferente método, com base no formalismo matemático, escolha racional, na 
filosofia analítica e na economia neoclássica, entre outras influências não marxistas, como salientam Boffo (2012) e Howard e King (1992) $)^{21}$, esses autores recebem frequentemente a denominação de marxistas analíticos, mas também de marxistas de escolha racional, subgrupo que lança mão exclusivamente do individualismo metodológico na definição de microfundamentos, abandonando a teoria do valor. Com modificações nos modelos neoclássicos de equilíbrio geral, mercado de trabalho e outros, foram desenvolvidos resultados diferentes da abordagem neoclássica que apresentavam situações de exploração e luta de classes na esfera da circulação, como, por exemplo, em Roemer $(1981)^{22}$.

Torna-se importante entender, como descrito no capítulo anterior, que essa perspectiva apresenta método inconciliável ao de Marx e parece acrescentar menos elementos à abordagem do próprio autor. Como são buscados elementos das firmas dentro do paradigma desenvolvido por Marx, essas interpretações fogem ao escopo do trabalho. Ainda assim, Goldstein (2006) argumenta que, descartadas determinadas posições fundamentalistas, como a do individualismo metodológico, são importantes os comportamentos microeconômicos definidos a partir de Marx, que devem ser integrados para melhor compreensão e análise do capitalismo.

Assim, a discussão a partir de Marx (1857/58, 1867, 1885, 1894), considerando preocupações atuais na teoria econômica, pode ser empreendida de acordo com a forma como firma está organizada na economia e com a acumulação e o circuito do capital industrial e seus elementos.

\subsubsection{A firma com base em Marx}

A firma capitalista tem associação importante ao sistema que é regido por relações mercantis, pela acumulação de capital e pelo objetivo do lucro. Ainda que Marx não trate especificamente da teoria da firma como é compreendido contemporaneamente esse campo de pesquisa, parece implícita na concepção de Marx a noção de firma como lócus

\footnotetext{
${ }^{21}$ De acordo com Howard e King (1992, p. 335), “in analysing Marx's work, the concepts and ideas of non-Marxian theory have figured prominently, and especially those of analytical philosophy, mathematical model-building, modern psychology and neoclassical economics. Rational choice Marxism is therefore clearly revisionist".

${ }^{22}$ As desigualdades nas dotações e direitos de propriedade seriam determinantes da exploração, a qual deveria ser combatida em termos morais, para esses autores.
} 
do processo de trabalho e acumulação no capitalismo, por causa do desenvolvimento histórico da relação social ínsita no conceito de capital.

Em razão da maneira pela qual se produz o lucro no capitalismo, a análise de Marx (1867) é centrada na produção de mais-valia ou mais-valor ${ }^{23}$, que só ocorre por meio do trabalho produtivo, gerador de excedente. A relação social vinculada a essa forma de geração e apropriação de valor fornece conteúdo ao conceito de modo de produção capitalista $^{24}$. Nessa relação social, a firma produtiva adquire alguns contornos gerais, que independem da mercadoria específica produzida, mas que a posicionam no centro da produção de valor da economia.

O trabalho, independentemente da formação social, corresponde a transformação ou a metabolismo entre os seres humanos e a natureza, em que o mundo natural é consciente e intencionalmente modificado ${ }^{25}$. Os elementos mais simples do processo de trabalho são o trabalho em si, atividade pretendida conscientemente; o objeto sobre o qual atua o trabalho; e os instrumentos do trabalho. Compreendendo os meios de produção e sendo resultado de trabalho anterior, os objetos trabalhados são matérias-primas, enquanto os instrumentos são ferramentas, máquinas e infraestrutura associada ao processo.

No processo de trabalho especificamente capitalista, Marx mostra elementos da organização da produção na qual os meios de produção e a força de trabalho são comprados pelo capitalista no mercado. A força de trabalho é consumida por meio da supervisão e controle do capitalista, que detém a propriedade do produto realizado. Marx (1867, p. 262) entende que:

Como processo de consumo da força de trabalho pelo capitalista, o processo de trabalho revela dois fenomenos característicos. (...) O trabalhador labora sob o controle do capitalista, a quem pertence o seu trabalho. (...) Em segundo lugar, porém, o produto é propriedade do capitalista, não do produtor direto, do trabalhador.

Ao mesmo tempo em que gera valores de uso, esse processo implica valorização, resultando em valor acima do que foi contratado, por causa do valor adicional criado pelo

\footnotetext{
${ }^{23}$ A tradução mais-valor tem sido utilizada pela edição da Boitempo das obras de Marx e Engels de acordo com a Marx-Engels-Gesamtausgabe (MEGA).

${ }^{24}$ Segundo Harvey (1982, p. p. 25), "by the capitalist mode of production he often means the characteristic form of the labour process under the class relations of capitalism (including, of course, the production of surplus value), presuming production of commodities for exchange. This is the main way in which Marx uses the concept throughout Capital".

${ }^{25}$ Lukács (1984) ressalta como característica ontológica do ser social esse pôr teleológico do trabalho.
} 
trabalho, frente ao que foi pago como força de trabalho. O capital tem comando sobre a força de trabalho, que não tem outro meio de subsistência senão apresentar-se para a venda no mercado de trabalho. Também o capital tem comando sobre o trabalho, ao ditar o ritmo e a forma de produzir.

No processo de valorização, o capitalista almeja produzir não apenas um valor de uso, mas obter mais valor, o que advém do processo de trabalho produtivo que gera mercadorias com maior valor do que foi contratado como capital, pela extração de maisvalia. Marx (1867, p. 263) define que:

Na produção de mercadorias, o valor de uso não é, de modo algum, a coisa qu'on aime pour lui même [que se ama por ela mesma]. (...) [O capitalista] quer produzir não só um valor de uso, mas uma mercadoria; não só valor de uso, mas valor, e não só valor, mas também mais-valor.

Desse modo, o processo de produção mostra unidade entre geração de valor e de maisvalia $^{26}$.

Esses elementos do processo de trabalho indicam alguns traços das firmas no capitalismo. Para Hodgson (2001) e Cabello (2014), a definição da firma para Marx pode ser entendida como uma instituição na qual: o trabalhador trabalha sob o controle do capitalista, a quem pertence o trabalho realizado; o produto é propriedade do capitalista, não do trabalhador; e as firmas produzem mercadorias para venda em busca de lucro.

As noções relacionadas ao processo de trabalho e a concepção da firma devem ser interpretadas em conjunto também com outras características, como a cooperação, a divisão do trabalho e a maquinaria. Marx, ao discutir a produção de mais-valia relativa, na Parte IV de O Capital (1867), mostra algumas características que podem ser próprias das firmas industriais e da especificidade da indústria de transformação no capitalismo.

$\mathrm{Na}$ explicação do avanço das forças produtivas e da produção capitalista ${ }^{27}$, são estudados avanços organizacionais, como na cooperação e na divisão do trabalho, e tecnológicos, como o uso de máquinas e automação. A produção capitalista só pode começar quando determinado capital individual, ou firma, ocupa número considerável de trabalhadores, ou seja, "o processo de trabalho aumenta seu volume e fornece produtos numa escala quantitativa maior que antes" (ibid., p. 397).

\footnotetext{
${ }^{26}$ Segundo Marx (1867, p. 273): "O processo de produção, como unidade dos processos de trabalho e de formação de valor, é processo de produção de mercadorias; como unidade dos processos de trabalho e de valorização, ele é processo de produção capitalista, forma capitalista da produção de mercadorias."

${ }^{27}$ Especialmente na discussão sobre a produção de mais-valia relativa, em Marx (1867, Parte Quarta).
} 
A cooperação e a divisão do trabalho, que são verificadas ao longo da história, adquirem dimensão ampliada e sistemática na organização do processo de trabalho no capitalismo, em razão da disponibilidade de mão de obra assalariada em grande número. No processo de acumulação e concorrência, a cooperação torna-se cogente, uma vez que o poder coletivo do trabalho deve ser utilizado para produzir de acordo com o tempo socialmente necessário. Para Marx (ibid, p. 400), a "forma de trabalho dentro da qual muitos indivíduos trabalham de modo planejado uns ao lado dos outros e em conjunto, no mesmo processo de produção ou em processos de produção diferentes porém conexos[,] chama-se cooperação".

Passa a ocorrer tanto a elevação da força produtiva individual quanto a criação de uma força produtiva nova, derivada do trabalhador coletivo, sem que se majorem os salários individuais. Verifica-se que "a força produtiva específica da jornada de trabalho combinada é a força produtiva social do trabalho ou força produtiva do trabalho social. Ela deriva da própria cooperação. Ao cooperar com outros de modo planejado, o trabalhador supera suas limitações individuais e desenvolve sua capacidade genérica [Gattungsvermögen]" (ibid., p. 405) 28 .

No contexto da cooperação, a jornada coletiva adquire dimensão social importante e não configura apenas aumento da força produtiva individual, mas sim força de massas que supera a soma das jornadas individuais e gera montante mais elevado de valor de uso. Essa cooperação (ibid., p. 401):

surge da fusão de muitas forças numa força conjunta, o simples contato social provoca, na maior parte dos trabalhos produtivos, emulação e excitação particular dos espíritos vitais [animal spirits] que elevam o rendimento dos trabalhadores individuais (...). A razão disso está em que o homem é, por natureza, se não um animal político, como diz Aristóteles, em todo caso um animal social.

Como escreve Marx ${ }^{29}$, os animal spirits dos trabalhadores são despertados pela cooperação e são deslanchados por causa da natureza humana de animal social.

Para Marx, duas condições para a cooperação estão associadas ao capitalista. Para a organização cooperativa, necessita-se de escala e capital mínimos, já que (ibid., p. 405) a "concentração de grandes quantidades de meios de produção em mãos de cada

\footnotetext{
${ }^{28}$ Nesse caso, a tradução da edição inglesa refere-se a "develops the capabilities of his Species", ou seja, enquanto desenvolve a capacidade como ser social.

${ }^{29}$ A versão original em alemão continha o uso por Marx da expressão animal spirits em inglês, que foi mantida na tradução recente em português
} 
capitalista é (...) a condição material para a cooperação de trabalhadores assalariados, e a extensão da cooperação, ou a escala da produção, depende da amplitude dessa concentração."

Ao mesmo tempo, a partir da cooperação e da escala ampliada com muitos assalariados, o comando e a direção do capitalista tornam-se condição para a execução do processo de trabalho, situação na qual a subsunção do trabalho ao capital se torna real. "Essa função de direção, supervisão e mediação torna-se função do capital assim que o trabalho a ele submetido se torna cooperativo" (ibid., p. 406). Como processo de valorização e produção de mais-valia, essa autoridade é direcionada para disciplinar a resistência dos trabalhadores e incorporá-los à relação social do capital ${ }^{30}$, bem como para controlar a utilização adequada, ou eficiência, dos meios de produção. Como processo social de trabalho para geração de valores de uso, a conexão entre os trabalhadores e sua unidade no corpo produtivo reside externamente sob o controle do capital. Dessa forma, entende Marx (ibid., p. 408) que o “capitalista não é capitalista por ser diretor da indústria; ao contrário, ele se torna chefe da indústria por ser capitalista. O comando supremo na indústria torna-se atributo do capital (...)”. Esse controle despótico, associado à lei do valor (determinado pelo tempo de trabalho socialmente necessário) e imposto pela concorrência, possibilita aumento na acumulação e na divisão técnica do trabalho (ou interna à firma).

A importância da atividade do empreendedor não está, pois, ausente, e figura, inclusive, como trabalho produtivo, se realizado em atividades produtivas. Marx, em Results of the Immediate Process of Production (1864, p. 1084) ${ }^{31}$, expõe que:

As the representative of productive capital engaged in the process of self-expansion, the capitalist performs a productive function. It consists in the direction and exploitation of productive labour. In contrast to his fellow-consumers of surplus-value who stand in no such immediate and active relationship to their production, his class is the productive class par excellence. (As the director of the labour process the capitalist performs productive labour in the sense that his labour is involved in the total process that is realized in the product.)

\footnotetext{
${ }^{30}$ Com o desenvolvimento do capitalismo, o capitalista pode-se desfazer dessa atividade de supervisão e entregá-la a um tipo especial de assalariado, gerando separação entre propriedade e controle.

${ }^{31}$ Publicado no Brasil como o Capítulo VI Inédito de O Capital.
} 
O controle do processo de autoexpansão torna-se atividade essencial da firma para a direção e a exploração de trabalho produtivo ${ }^{32}$.

$\mathrm{Na}$ evolução de formas de produção, a manufatura constitui forma de cooperação baseada em divisão do trabalho com artesanato ou ofícios manuais. Aumenta-se a produtividade dentro da oficina por meio do chamado trabalhador coletivo, formado de vários trabalhadores que realizam operações parciais ou especializadas para o capital e constituem o item de maquinário da manufatura ${ }^{33}$. A execução de operações parciais (com a divisão do trabalho e a criação de ferramentas adaptadas) de maneira repetida implica aprendizado e aumento de produtividade, como já afirmara Smith (1776). Para Marx (1867), esse aprendizado toma dimensão ampliada por causa do trabalhador coletivo e influencia toda a economia ${ }^{34}$. A escala (e o volume mínimo de capital necessário) expande-se com o maior número de trabalhadores e meios de produção.

A divisão do trabalho ocorre em benefício do capital, que se apropria das vantagens advindas dessas transformações. Os ganhos organizacionais do trabalho coletivo são incorporados sem custo. Desenvolve-se hierarquia das forças produtivas a partir da classificação dos trabalhadores segundo a qualificação, para permitir salários diferenciados e racionalização dos custos com capital variável, o que seria a característica fundamental da divisão do trabalho, ressalta Braverman (1974). Ao mesmo tempo, diminuem-se habilidades individuais por causa da fragmentação, simplificação e

\footnotetext{
32 Menos do que a busca da eficiência e da diminuição de custos, o controle na firma pretende, principalmente, a incorporação e a submissão dos trabalhadores para a continuidade do trabalho no processo de valorização. Ver, nesse sentido, Marglin (1974).

${ }^{33}$ Marx (1867, p. 423) explica que: "O trabalhador coletivo dispõe agora de todas as qualidades produtivas no mesmo grau de virtuosidade e as despende, ao mesmo tempo, do modo mais econômico, concentrando todos os seus órgãos, individualizados em trabalhadores ou grupos de trabalhadores especializados, no desempenho exclusivo de suas funções específicas. A unilateralidade e mesmo a imperfeição do trabalhador parcial convertem-se em sua perfeição como membro do trabalhador coletivo."

${ }^{34}$ Nesse aspecto, Tregenna (2013) reconhece o conceito de learning-by-doing na discussão empreendida em O Capital. As observações de Marx permitem entender economias dinâmicas de escala associadas à divisão do trabalho e à socialização do trabalho. Com efeito, Marx (1867, p. 414) esclarece "um trabalhador que executa uma mesma operação simples durante toda sua vida transforma seu corpo inteiro num órgão automaticamente unilateral dessa operação e, consequentemente, precisa de menos tempo para executá-la do que o artesão que executa alternadamente toda uma série de operações. Mas o trabalhador coletivo combinado, que constitui o mecanismo vivo da manufatura, consiste de muitos desses trabalhadores parciais e unilaterais. Por isso, em comparação com o ofício autônomo, produz-se mais em menos tempo, ou a força produtiva do trabalhador é aumentada (...). Também o método do trabalho parcial se aperfeiçoa depois de estar autonomizado como função exclusiva da pessoa. Como a experiência o demonstra, a contínua repetição da mesma ação limitada e a concentração da atenção nessa ação ensinam a atingir o efeito útil visado com o mínimo de dispêndio de força. Mas como diferentes gerações de trabalhadores convivem simultaneamente e cooperam nas mesmas manufaturas, os artifícios [Kunstgriffe] técnicos assim obtidos se consolidam, se acumulam e são transmitidos com rapidez (...). A manufatura produz, com efeito, a virtuosidade do trabalhador detalhista, quando, no interior da oficina, reproduz e leva sistematicamente ao extremo a diferenciação natural-espontânea dos ofícios."
} 
especialização do trabalho, separando mais os trabalhadores dos meios de produção e distanciando-os, como indivíduos, do trabalho social realizado ${ }^{35}$. A especialização excessiva, diminuindo o valor da mão de obra, ao gerar mais trabalhadores não qualificado, pode implicar também falta de desenvolvimento de habilidades ${ }^{36}$.

A divisão do trabalho interna à firma no capitalismo se destaca pelo caráter planejado, a priori, em contraste com a divisão social do trabalho, que corresponde a situação de anarquia de produtores independentes, com trocas de mercadorias realizadas a posteriori. Enquanto a divisão social do trabalho constitui totalidade de formas heterogêneas de trabalho útil, trocando-se mercadorias diferentes, Marx (1867, p. 429) nota que, na divisão manufatureira do trabalho, "o trabalhador parcial não produz mercadoria" e apenas "o produto comum dos trabalhadores parciais converte-se em mercadoria". Dessa forma:

Enquanto a divisão manufatureira do trabalho pressupõe a concentração dos meios de produção nas mãos de um capitalista, a divisão social do trabalho pressupõe a fragmentação dos meios de produção entre muitos produtores de mercadorias independentes entre si.

A economia política clássica, inclusive Smith (1776), não reconhecia essa separação, que é distintiva do caráter capitalista da divisão manufatureira do trabalho ${ }^{37}$. A economia política admitiria diferença apenas de grau. O contraste feito por Marx entre essas formas

\footnotetext{
${ }^{35}$ Segundo Tauile (2001, p. 63), a organização da produção pelo empresário capitalista está associada à atribuição de tarefas diferentes a pessoas distintas, implicando a quebra do monopólio do conhecimento do trabalho sobre o processo de trabalho. O trabalho torna-se menos qualificado. O autor pondera que a defesa feita por Smith (1776) da divisão do trabalho pela especialização não significa que ocorre maior qualificação. As habilidades dos trabalhadores se tornam menores, ao realizarem tarefas mais especializadas.

${ }^{36}$ Para Marx (1867, p. 424), "Em todo ofício de que se apodera, a manufatura cria, portanto, uma classe dos chamados trabalhadores não qualificados, antes rigorosamente excluídos pelo artesanato. Ao mesmo tempo que se desenvolve, à custa de capacidade total de trabalho, a especialidade totalmente unilateralizada, que chega ao ponto da virtuosidade ela já começa a transformar numa especialidade a falta absoluta de desenvolvimento. Juntamente com a gradação hierárquica, surge a simples separação dos trabalhadores em qualificados e não qualificados. Para estes últimos, os custos de aprendizagem desparecem por completo, e para os primeiros esses custos são menores, em comparação com o artesão, devido à função simplificada. Em ambos os casos diminui o valor da força de trabalho. Exceções ocorrem na medida em que a decomposição do processo de trabalho gera funções novas e abrangentes que no artesanato não existiam, ou pelo menos não na mesma extensão. A desvalorização relativa da força de trabalho, decorrente da eliminação ou redução dos custos de aprendizagem, implica imediatamente uma maior valorização do capital, pois tudo o que encurta o tempo de trabalho necessário para a reprodução da força de trabalho estende, ao mesmo tempo, os domínios do mais-trabalho".

${ }^{37}$ Para Marx, em Smith a divisão social do trabalho teria distinção apenas subjetiva da divisão do trabalho na manufatura, sendo mais difícil de observar diretamente os ramos da produção fora do espaço da oficina. Marx destaca que existe discrepância essencial entre as duas formas de divisão do trabalho.
} 
de divisão do trabalho suscita implicitamente a possibilidade de supor outras formas de controle e regulação social conscientes do processo social de produção ${ }^{38}$.

A base ainda existente de ofício manual da manufatura, que conferia certa autonomia ao trabalhador, pôde ser eliminada com a introdução da maquinaria na indústria moderna, na qual a produção é revolucionada pelos meios e instrumentos de trabalho, e não apenas pela força de trabalho. As características de subjetividade da especialização e das habilidades humanas são substituídas pelo processo objetivo de relações entre número, tamanho e velocidade das máquinas, que levam à automação na grande indústria. Responsável pela Revolução Industrial do século XVIII ${ }^{39}$, a máquinaferramenta é elemento central da indústria e constitui mecanismo que "executa com suas ferramentas as mesmas operações que antes o trabalhador executava com ferramentas semelhantes" (ibid., p. 447-48). Concretiza-se transferência das habilidades e conhecimento produtivo humanos da esfera do trabalho para a do capital.

A habilidade do trabalhador é transferida, com a ferramenta de trabalho, para a máquina, tornando a capacidade de rendimento da ferramenta emancipada das limitações pessoais da força humana de trabalho. Supera-se, desse modo, a base técnica da divisão do trabalho na manufatura. Utilizando-se a potência proveniente da máquina motriz e eliminando também os limites físicos da força humana, diversas máquinas-ferramentas podem ser movidas ao mesmo tempo. Por meio da divisão do trabalho na grande indústria, reaparece a cooperação peculiar à manufatura, com a combinação de máquinas parciais que engendra o sistema de maquinaria. A produção mecanizada atinge forma mais desenvolvida com o sistema articulado de máquinas de trabalho movidas por um autômato central via maquinaria de transmissão. Assim, na perspectiva dialética de Marx, o autômato mecânico torna-se sujeito e os operários, objeto do processo de trabalho, invertendo-se a situação anterior. Enquanto na manufatura e no artesanato o trabalhador

\footnotetext{
${ }^{38}$ Marx (1867, p. 430), embora não elabore sobre outras possibilidades, limitando-se a ressaltar formas sociais anteriores ao capitalismo, nas quais existe divisão social do trabalho submetida a planejamento e autoridade, sem divisão manufatureira do trabalho (como as comunidades indianas, ou ainda as corporações de ofício), indica como existe aversão ao pensamento sobre alternativas: "a mesma consciência burguesa que festeja a divisão manufatureira do trabalho, a anexação vitalícia do trabalhador a uma operação detalhista e a subordinação incondicional dos trabalhadores parciais ao capital como uma organização do trabalho que aumenta a força produtiva denuncia com o mesmo alarde todo e qualquer controle e regulação social consciente do processo social de produção como um ataque aos invioláveis direitos de propriedade, liberdade e à 'genialidade' autodeterminante do capitalista individual'.

39 Essa inovação, emblemática no caso da máquina de fiar, seria mais importante do que as partes do maquinário utilizadas como fonte de força motora, como a máquina a vapor, ou os mecanismos de transmissão. A máquina a vapor não originou a Revolução Industrial, mas as máquinas-ferramentas geraram demanda para aquela máquina, para substituir a força motriz humana, que é limitada.
} 
se serve da ferramenta, na fábrica ele serve à máquina ${ }^{40}$. Ademais, a máquina associa-se ao prolongamento (por meio da necessidade técnica e econômica de utilizar ao máximo a máquina) e à intensificação (pela diminuição da porosidade do trabalho) da jornada de trabalho.

A firma industrial apresenta características próprias no capitalismo em decorrência da subsunção real do trabalho ao capital. O assalariamento, que está associado à subsunção formal, não transforma a essência do processo de trabalho. Marx (1864) revela que a subsunção se torna real quando os capitalistas reorganizam o processo de trabalho para a extração de mais-valia relativa, por meio da utilização das máquinasferramentas, ocorrendo assim a forma especificamente capitalista de produção. As mudanças tecnológicas, como a evolução da maquinaria e o uso sistemático da ciência no processo produtivo, estão vinculadas a essas relações sociais.

A maquinaria e a mecanização tornam-se centrais para o desenvolvimento econômico e se desenvolvem com a expansão da firma essencialmente capitalista. A grande indústria criou base técnica adequada ao incorporar a produção máquinas por meio de máquinas. A indústria de transformação, que produz as máquinas e equipamentos, ganha relevo para a expansão dos meios de produção e para economia como um todo. Desse modo, Marx (ibid., p. 532) assinala que:

Com o desenvolvimento do sistema fabril e o conseguinte revolucionamento da agricultura, não só se amplia a escala da produção nos demais ramos da indústria como também se modifica seu caráter. Por toda parte torna-se determinante o princípio da produção mecanizada, a saber, analisar o processo de produção em suas fases constitutivas e resolver os problemas assim dados por meio da aplicação da mecânica, da química etc., em suma, das ciências naturais. Logo, a maquinaria se impõe, ora neste, ora naquele processo parcial no interior das manufaturas.

Os encadeamentos gerados pela atividade industrial tornam-se essenciais para o desenvolvimento das forças produtivas. O efeito intersetorial da indústria, ao penetrar em processos produtivos de outras atividades, é igualmente ressaltado por Marx (ibid., p. 516):

\footnotetext{
${ }^{40}$ Cabe notar que Marx não acredita que o processo histórico de subordinação do trabalho tenha ocorrido sem contestações. A ação violenta de empresários e do Estado, além de práticas de roubo e espoliação foram marcantes.
} 
À medida que a indústria mecanizada, com um número de trabalhadores relativamente menor, fornece uma massa cada vez maior de matérias-primas, produtos semiacabados, instrumentos de trabalho etc., a elaboração dessas matérias-primas e produtos intermediários se divide em inúmeras subespécies e incrementa, assim, a diversidade dos ramos da produção social. A indústria mecanizada impulsiona a divisão social do trabalho muito mais do que a manufatura, pois amplia em grau incomparavelmente maior a força produtiva dos setores de que se apodera.

Ainda que se dissemine no capitalismo, o processo de mecanização tem contradições e limites, assim como impactos significativos sobre o emprego. A produtividade da máquina é medida pelo grau em que substitui a força humana de trabalho. $\mathrm{O}$ valor da máquina deve superar a economia com gastos salariais. Assim, (ibid., p. 480):

$\mathrm{Na}$ aplicação da maquinaria à produção de mais-valor reside (...) uma contradição imanente, já que dos dois fatores que compõem o mais-valor fornecido por um capital de dada grandeza, um deles, a taxa de mais-valor, aumenta somente na medida em que reduz o outro fator, o número de trabalhadores. Essa contradição imanente se manifesta assim que, com a generalização da maquinaria num ramo industrial, o valor da mercadoria produzida mecanicamente se converte no valor social que regula todas as mercadorias do mesmo tipo.

Com a cristalização do novo tempo socialmente necessário de trabalho para determinada mercadoria, os ganhos com monopólio temporário da tecnologia anterior exaurem-se (comparativamente à situação anterior). Como consequência, há queda na taxa de lucro da firma, que aumentou a composição do capital constante frente ao capital variável, não obstante possa haver aumento da massa de lucros, o que importa para o capitalista.

Dessa forma, a firma para Marx pode ser compreendida como categoria decorrente do desenvolvimento histórico e não está associada apenas à racionalização de custos ou a ganhos de escala ${ }^{41}$. A organização da produção por meio da firma capitalista tem características essenciais que a diferenciam de outras formas organizacionais em diferentes formações sociais. O processo de trabalho no capitalismo, alicerçado na relação

\footnotetext{
${ }^{41}$ Para Cabello (2014), a autoridade e a hierarquia na firma capitalista, bem como a relação contratual de emprego, presentes na concepção de Marx, estariam próximas da perspectiva de Coase (1937). Também a firma seria forma de redução de custos para Coase e Marx, possibilitando economia com relação ao uso do mecanismo de mercado, para o primeiro, e com respeito à escala de produção, para o segundo. A perspectiva histórica de Marx diferenciar-se-ia da abordagem em termos lógicos (e atemporais) de Coase. Como discutido, do ponto de vista de Marx, a firma não se justifica pela eficiência, mas sim pela atuação essencial no processo de trabalho capitalista.
} 
de valor, é central para explicação de Marx e fornece diversos elementos teóricos para a interpretação da firma, em aspectos como hierarquia e controle, qualificações e capacidades e divisão do trabalho no sistema capitalista ${ }^{42}$. A concepção da firma, no entanto, não deixa de revelar contradições associadas à lei do valor, como a relação entre o trabalho individual abstrato e menos qualificado ${ }^{43}$ e os animal spirits advindos da cooperação e da divisão do trabalho na firma capitalista.

\subsubsection{Elementos da acumulação de capital}

Além da organização interna, o circuito ou ciclo de circulação do capital, em que são analisadas as fases ou metamorfoses do processo de valorização, e a interação entre diversas formas de capital também fornecem elementos para o entendimento da firma e do capital individual. As metamorfoses do capital, nos estágios D-M, P e M'-D', são discutidas mais minuciosamente no Livro II de O Capital $(1885)^{44}$. Os conceitos associados à acumulação adquirem caráter mais concreto de determinação com base na análise da esfera da circulação e da complexidade a ela associada também no Livro III (1894), podendo ser avaliados de maneira mais sistemática. São notadas possibilidades de interrupção das etapas do circuito do capital, o que pode tornar problemático o processo de valorização. Ainda que toda venda implique uma compra, existe a possibilidade de que nem toda riqueza seja realizada ${ }^{45}$. O tempo de rotação do capital torna-se importante para o objetivo da acumulação, já que a maior rapidez com o que o

\footnotetext{
42 Interpretações como a de Ho (2015), que destacam a divisão do trabalho em autores como Smith, Marx, Young e Hirschman, muitas vezes deixam de considerar a diferenciação fundamental da divisão do trabalho. Ho (2015) considera que podem ser encontradas em Smith (1776) duas formas distintas de divisão do trabalho, a de operações de produção (division of production operations) e a de especialização em produtos finais (final product specialisation). A diferença entre as duas formas parece mais relacionada ao papel das trocas no comércio internacional, se realizadas, respectivamente, em produtos intermediários ou finais. Nessa interpretação, embora sejam salientados aspectos relevantes da organização produtiva, permanece a percepção indiferenciada da divisão do trabalho interna à firma (que pode se estender internacionalmente) e da divisão social do trabalho. Destacando efeitos nocivos da especialização em certos elos menos qualificados das cadeias produtivas, Ho avança ao reconhecer a hierarquia de qualificação dos trabalhadores e a diminuição da qualificação com o desenvolvimento da indústria, ainda que considere essa discussão pouco comentada na literatura marxista.

${ }^{43}$ Como destaca Tauile (2001), que frisa a abstratificação do trabalho.

${ }^{44}$ Nessa análise do circuito, são feitas as hipóteses de que as mercadorias são vendidas a seus valores e que não há mudança tecnológica.

45 Para Lukács (1984, p. 323), “o fato de que da venda de uma mercadoria (M-D) não se segue necessariamente a compra de outra mercadoria (D-M) aponta, na forma de uma casualidade irrevogável, para a natureza distinta do processo global diante dos atos individuais. Só quando o processo global é investigado quanto às suas leis, relativas à totalidade da economia, é que essa apreensão formal deixa de ser suficiente"
} 
ciclo inicia e termina aumenta o lucro do capitalista. Também as relações setoriais e entre produções com distintos valores de usos são observadas.

O capitalista individual adianta capital-dinheiro (D) para comprar mercadorias (M) na forma de insumos. São comprados força de trabalho (FT), também chamado capital variável, e meios de produção (MP), conhecidos como capital constante, como máquinas e matérias-primas. Nessa situação, o dinheiro funciona não como meio de circulação ou pagamento, mas como capital. Esses insumos configuram capital produtivo que será transformado no processo de produção $(\mathrm{P})$, ao final do qual serão geradas diferentes mercadorias com maior valor em relação ao que foi adiantado, quando vendidas por dinheiro $\mathrm{D}^{\prime}=\mathrm{D}+\mathrm{d}$, em que d representa dinheiro adicional.

Esse valor adicionado, a mais-valia (s) criada, resulta da diferença entre o que foi pago como capital variável, o salário aos trabalhadores, e o valor gerado pela força de trabalho durante o processo produtivo, ou entre o trabalho pago e o não pago. Apesar de parecer que todos os insumos criam valor, essa interpretação superficial encobre a relação social de exploração por trás desse fenômeno, que é a diferença entre o trabalho pago e o não pago, já que o valor dos meios de produção é simplesmente transferido para o produto final e apenas o trabalho vivo gera valor. O lucro será obtido ao fim do processo, enquanto os salários são adiantados como capital variável.

O capital é relação que se apresenta como processo, no qual é o dinheiro ou valor que se autoexpande, de acordo com a produção, apropriação e acumulação de mais-valia. É o valor no processo de reproduzir-se como capital. No circuito do capital industrial, o capital toma diferentes formas, como capital-dinheiro (D), capital produtivo (P) e capitalmercadoria (M). A esfera da produção gera mais-valia entre $M$ e $M^{\prime}$, enquanto a da circulação ou troca contém o processo de venda de mercadorias, em que ocorre a realização da mais-valia s. Essas metamorfoses encontram-se integradas pelo movimento do capital como valor que é produzido, distribuído e trocado. Se alguma parcela da maisvalia (s) for acumulada para uso como capital, ocorre reprodução ampliada. No entanto, a realização da mais-valia pode não ocorrer, enquanto a venda $D^{\prime}=D+d$ pode trazer dinheiro adicional que pode ser entesourado, gasto em consumo ou adicionado ao circuito do capital.

$\mathrm{Na}$ relação D-M, o comprador transforma o dinheiro em mercadorias, os vendedores, suas mercadorias em dinheiro. Nem todo dinheiro é capital. O dinheiro só se transforma em capital se entrar no circuito de valorização do capital. Parte do dinheiro vai para o trabalhador, cujo circuito se torna M-D-M, de compra de bens salários, sem 
constituir uma circulação de capital, mas compreendendo o dinheiro como meio de circulação apenas, com a conversão de uma mercadoria em outra. A etapa D-FT é uma característica do capitalismo, por causa dos salários monetários e do mercado de trabalho, em que os agentes são vendedores independentes, e só pode ocorrer se tiver havido o processo histórico de separação de propriedade dos meios de produção. É necessário haver mercados definidos de bens salários, de meios de produção e de força de trabalho.

$\mathrm{Na}$ relação D-M, o capital-dinheiro pode estar fundado em lucros retidos, de propriedade do capitalista industrial, ou pode advir da moeda privada de crédito, que se situa na base da pirâmide monetária na economia capitalista (Brunhoff, 1985). A moeda de crédito é criada e destruída nas transações entre bancos e capitalistas industriais. $\mathrm{O}$ empréstimo do banco para financiar a produção e a venda de mercadorias ocorre por meio de emissão de moeda, sendo que, no final do circuito D-M-D', esse empréstimo deverá ser pago.

Embora as firmas, de um ponto de vista individual, estejam perseguindo ganho monetário, cuja expressão maior, de venda mais cara do que a compra, está associada ao capital mercantil e ao capital portador de juros, apenas na esfera da produção é gerado valor, o que impõe limites ao desenvolvimento de uma economia. A criação de valor na produção só é efetivada por meio da realização pela venda, o que é incerto. A reprodução ampliada é dificultada também pela necessidade de acumular montante suficiente de capital-dinheiro para ampliar o processo de produção. Marx reconhece esse requerimento de capital mínimo e admite a necessidade de entesouramento para financiar essa expansão da escala ${ }^{46}$.

Os três circuitos do capital são formados do circuito como um todo, o capital industrial. Diferentes visões do processo de reprodução do capital podem ser compreendidas de acordo com cada circuito. Marx (1885, p. 182) argumenta que:

\footnotetext{
${ }^{46}$ Marx (1885, p. 157) expõe que: "Como as proporções em que se pode ampliar o processo de produção são determinadas não de forma arbitrária, mas de forma técnica, pode ocorrer, e de fato ocorre com frequência, que o mais-valor realizado, embora destinado à capitalização, cresça (sendo, portanto, acumulado nas proporções necessárias), mediante a repetição dos diferentes ciclos, até atingir o volume em que pode realmente funcionar como capital adicional ou ingressar no ciclo do valor de capital em processo. O mais-valor imobiliza-se, assim, como tesouro e, sob essa forma, constitui o capital monetário latente. Latente porque, enquanto imobilizado sob a forma-dinheiro, não pode atuar como capital (...). Assim, o entesouramento aparece aqui como um momento implícito no processo capitalista de acumulação, um momento que lhe é inerente mas, ao mesmo tempo, dele essencialmente distinto. Pois o próprio processo de reprodução não é ampliado mediante a formação do capital monetário latente. Ao contrário, o capital monetário latente é aqui constituído porque o produtor capitalista não pode ampliar imediatamente a escala de sua produção."
} 
o verdadeiro ciclo do capital industrial, em sua continuidade, não é apenas a unidade dos processos de circulação e produção, mas a unidade de todos os seus três ciclos. (...) O ciclo inteiro se apresenta para cada forma funcional do capital como seu ciclo específico, e cada um desses ciclos condiciona a continuidade do processo em seu conjunto; o processo cíclico de uma forma funcional condiciona o da outra. É uma condição necessária ao processo total de produção, especialmente para o capital social, que ele seja simultaneamente processo de reprodução e, assim, ciclo de cada um de seus momentos. Diferentes frações do capital percorrem sucessivamente os diversos estágios e formas funcionais. Cada forma funcional, embora nela se expresse sempre outra parte do capital, percorre seu próprio ciclo ao mesmo tempo que as outras. Uma parte do capital, que muda e se reproduz sem cessar, existe como capital-mercadoria, que se converte em dinheiro; outra parte existe como capital monetário, que se converte em capital produtivo; a terceira, capital produtivo, se converte em capital-mercadoria. A existência constante dessas três formas é mediada justamente pelo ciclo do capital total que percorre essas três fases.

Lukács (1984, p. 323-24) entende que o processo global da reprodução econômica compreendido na unidade desses três processos, cada qual com três níveis (os ciclos do capital-dinheiro, do capital produtivo e do capital-mercadoria) não se trata de decomposição simplesmente metodológica, mas do fato de que três processos econômicos reais se articulam em conjunto, em um processo unitário. Assim, "a decomposição conceitual não é nada mais que um espelhamento no pensamento dos três processos da reprodução: o capital industrial, o capital comercial e o capital monetário".

Desse modo, a acumulação de capital torna-se a aplicação de mais-valor como capital ou a reconversão de mais-valor em capital. A acumulação constitui reprodução do capital em escala progressiva. Ocorre crescimento tanto no capital constante quanto no capital variável, mas em proporções diversas. A escala ampliada difere da reprodução simples em razão de o mais-valor não ser todo direcionado a gasto capitalista em consumo próprio e trabalho para satisfação de necessidades naturais ou sociais, que constitui renda. Marx (1867) explica que a concepção da Economia Política clássica sobre acumulação é errônea, ao associar a reprodução em escala ampliada com a abstinência. Esse processo deve-se ao investimento, que vai gerar a renda que poderá ser poupada posteriormente.

De acordo com a Marx (ibid., p. 670), apresenta-se como imperativo ao capital a "acumulação pela acumulação, a produção pela produção":

Acumulai, acumulai! Eis Moisés e os profetas! 'A indústria provê o material que a poupança acumula' (...). Portanto, poupai, poupai, isto é, reconvertei em capital a maior parte possivel do mais-valor ou do mais-produto! 
Marx (1867, p. 690) formula também que, do ponto de vista do capital individual, apenas a expansão contínua faculta sobrevivência da firma:

o desenvolvimento da produção capitalista torna necessária a elevação contínua do capital empregado num empreendimento industrial, e a concorrência impõe a cada capitalista as leis imanentes do modo capitalista de produção como leis coercitivas externas. Compele-o a expandir continuamente seu capital para conservá-lo, e só pode expandi-lo por meio da acumulação progressiva.

Cabe notar que a concorrência reforça a necessidade de acumulação de capital, para Marx (1894), em especial na consideração da pluralidade de capitais heterogêneos na dinâmica relacionada a preços e valores ${ }^{47}$. Diferentemente da perspectiva mainstream, que contrapõe a concorrência à concentração, Marx estabelece teoricamente a inclinação do capitalismo para a crescente concentração de capitais, em duas dimensões, denominadas de concentração e centralização, ambas verificadas no processo de reprodução em escala ampliada do desenvolvimento econômico. A concentração está associada ao aumento de riqueza de um capital individual, e criação de novos capitais, ou do capital social da economia de maneira proporcional ${ }^{48}$. Já a centralização implica a redistribuição de capitais entre os capitalistas, com aumento da proporção do capital social abarcada por determinados capitalistas, ou a concentração dos capitais já formados ${ }^{49}$.

\footnotetext{
${ }^{47}$ A concorrência, conquanto não tenha precedência lógica sobre outros conceitos, desempenha papel fundamental no sistema teórico do autor, como também na consideração da dinâmica de valores e preços da pluralidade de capitais no Livro III. Passagem importante de Marx (1857/58, p. 737) evidencia o papel teórico da concorrência, que, embora seja locomotiva fundamental da economia, "não estabelece suas leis, mas é sua executora. Por essa razão, a concorrência ilimitada (...) não é o pressuposto para a verdade das leis econômicas, mas a consequência - a forma de manifestação em que sua necessidade se realiza." Possas (1989, p. 61), ainda que entenda a concorrência como instância lógica que antecede o valor, admite que "O capital como valor em processo de auto-expansão ou que se 'auto-valoriza' supõe (...) a concorrência (...) como a forma necessária de sua existência, entendida a lei do valor quer sob a ótica da reprodução social do capital, como base para a norma de sua distribuição entre setores e órbitas de ação, quer na qualidade de princípio geral das leis de movimento no capitalismo, que não podem ser pensadas e se manifestar senão mediante a interação dos múltiplos capitais em presença."

${ }^{48}$ Marx (1867, p. 728-29) argumenta que "Todo capital individual é uma concentração maior ou menor dos meios de produção, com o comando correspondente sobre um exército maior ou menor de trabalhadores. Cada acumulação se torna meio de nova acumulação. Ao ampliar-se a massa de riqueza que funciona como capital, a acumulação aumenta a concentração dessa riqueza nas mãos de capitalistas individuais e, em consequência, a base da produção em grande escala e dos métodos de produção especificamente capitalistas. O crescimento do capital social realiza-se através do crescimento de muitos capitais individuais. Não se alterando as demais condições, os capitais individuais e, com eles, a concentração dos meios de produção aumentam enquanto o capital social acresce. Ao mesmo tempo, frações dos capitais originais destes se destacam e funcionam como novos capitais independentes".

49 Já a centralização de capitais (ibid. p. 701-02), constitui "a concentração de capitais já constituídos”, mediante a "supressão [Aufhebung] de sua independência individual, expropriação de capitalista por capitalista, conversão de muitos capitais menores em poucos capitais maiores"
} 
$\mathrm{Na}$ acumulação progressiva, a relação com a tecnologia é intrínseca para Marx. Cabe notar que o pensamento de Marx acerca da influência da tecnologia sobre a ação humana não deve ser caracterizado como determinista. Marx $(1867$, p. 446) sustenta que:

A tecnologia desvela a atitude ativa do homem em relação à natureza, o processo imediato de produção de sua vida e, com isso, também de suas condições sociais de vida e das concepções espirituais que delas decorrem.

Menos do que considerar a evolução das forças produtivas e da base tecnológica como determinantes externos da atitude ativa do homem, a tecnologia (e seu estudo) revela as relações sociais e intelectuais vinculadas à produção da vida humana ${ }^{50}$.

Dessa maneira, Marx (1867, capítulo 23) define duas formas pelas quais acontece o processo de acumulação, sem e com mudança tecnológica. Na primeira situação, é mantida a composição orgânica do capital, o que implica que a acumulação ocorre com elevações proporcionais de capital constante e variável. Já se houver progresso tecnológico, existe substituição de trabalho vivo por trabalho morto, ou trabalho subjetivo por objetivo. Nesse caso, causa-se aumento na composição orgânica do capital, e, dessa maneira, o capital variável é aumentado em proporção menor do o capital constante.

O mercado de trabalho tem determinações importantes para Marx. Como a demanda de trabalho não é definida pelo volume do capital total, mas por seu componente variável, ela decresce progressivamente com o crescimento do capital total. Os movimentos gerais do salário são regulados pela expansão e contração do exército industrial de reserva, que se regem, por sua vez, pela alternância periódica do ciclo industrial. Não se determinam, portanto, pelo movimento do número absoluto da população trabalhadora, mas pela proporção em que a classe trabalhadora se divide em exército ativo e exército de reserva, pelo aumento ou redução do tamanho relativo da superpopulação, pelo grau em que ela é ora absorvida, ou liberada.

$\mathrm{O}$ aumento da mais-valia relativa é uma das principais ações para expandir a extração de mais-valia, pelo crescimento da produtividade do trabalho e da queda no valor dos bens-salários. O capitalista inovador aufere lucros extras, derivados de mais-valia extra, ao vender produtos fabricados com métodos e equipamentos mais produtivos que

\footnotetext{
${ }^{50}$ Harvey (2010, p. 193) entende que os elementos descritos nesta citação são momentos distintos do que é o processo de evolução humana: "technologies and organizational forms internalize a certain relation to nature as well as to mental conceptions and social relations, daily life and labor processes. By virtue of this internalization, the study of technologies and organizational forms is bound to "reveal" or "disclose" a great deal about all the other elements."
} 
reduzam o custo unitário em termos de valor até o momento em que essa inovação seja imitada e se torne o novo padrão socialmente necessário de valor na economia. Já o aumento da produtividade nos setores de bens-salários possibilita, especialmente, a diminuição do valor geral da força de trabalho ${ }^{51} \mathrm{e}$, portanto, o aumento do trabalho excedente em toda a economia. Ainda assim, Marx argumenta que o capitalista não procura conscientemente quedas específicas em bens-salário, mas busca crescimento da produtividade em geral, em decorrência da coerção advinda da concorrência ${ }^{52}$.

A inovação na economia é determinada de maneira endógena, por causa da busca pelo lucro e pela concorrência. O resultado da inovação em geral pode ser entendido pelo movimento de queda nos preços, causado por menores valores unitários. As firmas que não conseguirem produtividade semelhante aos líderes passam a receber menores lucros, o que gera redistribuição da mais-valia das firmas com tecnologia inferior para aquelas com tecnologia superior. As firmas com pior tecnologia, para sobreviver, devem adotar a nova técnica. Assim, o tempo de trabalho necessário para esse bem ou serviço deve diminuir. Como escreve Marx (1867, p. 393):

A mesma lei da determinação do valor pelo tempo de trabalho, que se apresentou ao capitalista, juntamente com o novo método de produção. Sob a forma de que ele é obrigado a vender sua mercadoria abaixo de seu valor social, força seus concorrentes, como lei coercitiva da concorrência, a aplicar o novo modo de produção.

Os lucros extraordinários são, portanto, individuais e transitórios, exceto quando atingem os bens-salários.

Os ganhos com produtividade podem não ser todos extraídos pelo capital. Pode haver melhoria para os trabalhadores por meio de maior acesso a valores-de-uso, mesmo com uma taxa de exploração crescente, como nota Harvey (2010). Igualmente, uma queda nos salários que não seja equivalente ao aumento da produtividade do trabalho, o que é factível por não haver relação entre produtividade marginal e salários, como na teoria neoclássica, pode engendrar elevação da renda dos trabalhadores.

\footnotetext{
${ }^{51} \mathrm{O}$ que possibilita o aumento da taxa de exploração, definida pela relação s/v, entre mais-valia (s) e capital variável $(\mathrm{v})$.

52 Marx (1867, p. 367) explica que "Se um capitalista, individualmente, barateia camisas, elevando a força produtiva de trabalho [produtividade], não tem ele necessariamente em mira reduzir em determinada percentagem o valor da força de trabalho e, consequentemente, o tempo de trabalho necessário, mas, na medida em que, por fim, contribui para esse resultado, concorre para elevar a taxa geral de mais-valia (...). As tendências gerais e necessárias do capital devem ser distinguidas de suas formas de manifestação.”
} 
Na discussão empreendida por Marx, o investimento em capital fixo em geral impõe desafios ao processo de acumulação. Continuidade, fluidez e velocidade são qualidades essenciais do fluxo de capital. O capital fixo auxilia na fluidez do circuito do capital, contudo, não se apresenta como fluido. É forma de capital que precisa ser fixada para que o resto do capital se mantenha em movimento.

No processo produtivo, Marx diferencia capital constante e variável, mas também capital fixo e circulante. O capital fixo, constituído por meios de produção que transferem valor aos poucos às mercadorias e duram mais de um período produtivo (máquinas e infraestrutura física de produção), contrasta com o capital circulante, que é transferido integralmente às mercadorias e formado por trabalho e meios de produção como matériasprimas, materiais auxiliares e energia. $\mathrm{O}$ capital fixo não transfere valor de uso às mercadorias, mas o mantém, enquanto insere parcela de valor na mercadoria.

A depreciação do capital fixo torna-se complexa. Marx (1885, capítulo 9) sustenta que a depreciação é a parcela do valor que o capital fixo transfere para o produto à medida que é utilizado, de acordo com certo grau médio de perda de valor-de-uso. Já a depreciação moral do capital fixo está associada à necessidade de substituição antes da exaustação física do equipamento, por causa da revolução constante nos meios de produção, a partir da concorrência com máquinas mais produtivas e de mais baixo custo. Dessa forma, o valor do capital fixo não está isento de mudanças no tempo (e possivelmente no espaço) $)^{53}$.

Para Marx (1867, p. 477), a máquina sofre um desgaste moral, ao perder valor de troca quando máquinas de mesmo tipo são produzidas a custo mais baixo ou máquinas melhores passam a ser concorrentes. O valor da máquina antiga já não é determinado pelo tempo de trabalho efetivamente objetivado nela, mas pelo tempo de trabalho necessário à sua própria reprodução ou à reprodução da máquina aperfeiçoada. De acordo com Harvey (1982), a definição de capital fixo de Marx revela aspectos físicos e econômicos para a mensuração do valor dessa espécie de capital. Para Harvey (1982, p. 212):

The capitalist discards a machine not because it is worn out physically, but because a higher profit can be had by replacing it. The use value of the machine to the capitalist is that it allows the latter to produce greater surplus value, and this use value, as Marx clearly recognizes, changes with social circumstances. The economic lifetime of a machine cannot, therefore, be known in advance, since it depends upon changes in the

\footnotetext{
${ }^{53}$ Harvey (1982, p. 2010) expõe que "the value of machinery is in a perpetual state of flux - a conclusion that is incompatible with a conception of value as 'embodied labour time' but which is surely consistent with Marx's conception of value as a social relation".
} 
design and cost of machinery, the general rate and form of technological change, the conditions affecting the rate of exploitation of labour power (the ebb and flow of the industrial reserve army, for example), profit rate differentials under different technologies within a given line of production, and so on. The lifetime of machines, being a social determination, is at best variable and at worst quite unpredictable - blown hither and thither by the winds of competition, the restless search for profit and an accumulation process that spawns such a dramatic pace of technological change. What began by seeming a solid material foundation for the analysis of value transfer is transformed by social processes into a quagmire of uncertainty.

Crotty (1993) também salienta que o capital fixo se desvaloriza com o progresso técnico. O valor do capital fixo para o capitalista depende da capacidade de extrair maisvalia do trabalho vivo. Como o progresso técnico reduz os custos unitários médios e, assim, abaixa o preço do produto final, haverá declínio da mais-valia gerada pelo capital fixo, o que, portanto, o desvalorizará. Dessa forma, a maneira pela qual o progresso técnico destrói o valor do capital fixo é indissociável do caráter contraditório da acumulação.

O processo de acumulação não está associado apenas à forma do capital produtivo, como se nota no circuito do capital. Outras formas permitem à firma, de um ponto de vista microeconômico, acumular capital, encurtando ou eliminando a necessidade do processo produtivo $(\mathrm{P})$, ainda que, de um ponto de vista global, a geração de valor se mantenha apenas nesta última esfera. Marx expõe outras formas de capital conforme o vínculo ao circuito específico, mas também relaciona essas formas a rendimentos e frações de classe específicos, em que os diversos capitais concorrem por maior parcela da mais-valia gerada na produção.

Para Mollo (2011, 2015), o desenvolvimento do crédito e do capital financeiro no capitalismo permite o desenvolvimento da produção, mas gera também tensões na esfera da circulação. O crédito potencializa a concentração e centralização de capitais. $\mathrm{O}$ crédito, ao ser tomado pelo capitalista industrial, intensifica a produção e agiliza a reprodução do capital. A utilização de recursos de terceiros possibilita que o capitalista invista em meios de produção e contratação da força de trabalho antes de auferir lucro suficiente para financiar com recursos próprios o investimento.

A taxa de juros, para os marxistas, não é resultado de alguma tendência natural, mas de uma relação de força. Chesnais (2010) ressalta a distinção de Marx (1894) entre lucro da empresa, que remunera o capitalista ativo e permite o investimento, e os juros, pertencentes ao capitalista passivo que se apropria de parcela da mais-valia gerada. Esse lucro aproxima-se do conceito de lucro retido. A taxa de juros resulta de relação de força, 
uma vez que não existe taxa natural. Do ponto de vista qualitativo, os juros são a maisvalia obtida pela simples posse do capital.

Para Marx, o capital produtor de juros só cria juros se o dinheiro emprestado se converter em capital e for gerado excedente, do qual são retirados os juros. A desvinculação entre o capital portador de juros e o circuito do capital industrial produz o capital fictício, o qual se descola da produção, conforme Mollo $(2011,2015)^{54}$. O capital financeiro, na concepção de Marx, inclui tanto o capital de empréstimo produtor de juros quanto o capital fictício. A possibilidade de crise associada à esfera financeira está associada à dificuldade de continuar a valorização do capital financeiro. O quadro é agravado com o capital fíctício, que retira recursos da acumulação de capital.

\subsection{A firma em Keynes e nos Pós-Keynesianos e o papel do investimento nas economias monetárias de produção}

Nesta seção, são avaliados aspectos fundamentais da noção de firma e os aspectos microeconômicos associados a organização, expectativas e dinâmica das firmas segundo a abordagem de Keynes e dos pós-keynesianos, assim como discutidos elementos centrais do investimento nas economias monetárias de produção. Esses autores enfatizam o papel da incerteza e das condições monetárias e financeiras no comportamento das firmas e do investimento na economia.

A perspectiva pós-keynesiana, embora identificada com pesquisas em nível macroeconômico, apresenta contribuições à teoria microeconômica, em especial na teoria da firma e na economia industrial. Diversos aspectos dos trabalhos seminais de Keynes (1936, 1937) e Chick (1983) podem ser notados com respeito ao comportamento microeconômico dos agentes. A literatura pós-keynesiana, que encontra muita interação com outras correntes de pensamento, observa questões essenciais da microeconomia, com base no comportamento dos indivíduos e das firmas em face de incerteza e mercados imperfeitos, em contraposição à teoria neoclássica.

\footnotetext{
${ }^{54}$ Essa noção do capital fictício, embora mais adequada à concepção de Marx, não é consensual entre os marxistas, observa Mollo (2011).
} 
$\mathrm{O}$ conceito de firma para Keynes e os pós-keynesianos está associado às características essenciais das economias monetárias de produção. A formulação teórica de Keynes sobre a incerteza, as expectativas e a importância do investimento em bens de capital parece determinante para contribuições posteriores.

Assim, são comentados elementos presentes principalmente na Teoria Geral de Keynes (1936), que se seguem das formulações pós-keynesianas sobre a organização e a dinâmica das firmas, principalmente das grandes empresas. Conquanto existam certas diferenças entre a abordagem seguida na Teoria Geral (1936) e as contribuições póskeynesianas, os conceitos definidos por Keynes para a escolha sob incerteza fundamental constituem base para desenvolvimentos posteriores sobre a teoria da firma.

\subsubsection{Firma para Keynes}

O objetivo do lucro para Keynes, já ressaltado anteriormente, aparece na fórmula de maximização segundo a qual (1936, p. 24-25) "entrepreneurs will endeavour to fix the amount of employment at the level which they expect to maximise the excess of the proceeds over the factor cost". As firmas vão maximizar o lucro esperado, que é definido em termos monetários como as receitas menos os custos dos fatores. Foi utilizada a hipótese de pequena firma na Teoria Geral, malgrado já existisse, nas décadas de 1920 e 1930, discussão crítica relevante e próxima ao autor sobre concorrência imperfeita, lembra Chick (1985). Ainda assim, a incerteza real das economias monetárias e o papel das expectativas tornam a escolha das firmas muito distinta do comportamento previsto na teoria ortodoxa.

Chick (1983) evidencia fundamentos microeconômicos presentes na Teoria Geral e destaca a concepção específica das firmas nessa perspectiva, as quais a autora denomina polipolísticas ${ }^{55}$. As decisões das firmas são consideradas centrais na Teoria Geral. A firma característica para Keynes é uma anomalia do ponto de vista do pensamento estabelecido, uma vez que representa agente atomístico que opera sob incerteza e não se constitui como tomador de preço. A consideração da firma pequena causa desapontamentos a diversos intérpretes, por causa da falta de realismo ou de adequação dessa hipótese. No entanto, a escolha de Keynes vem da vontade de desafiar a teoria neoclássica em seus próprios

\footnotetext{
${ }^{55}$ São firmas que atuam em estrutura de mercado designada por Chick (1983) de polipólio (polypoly), em que há muitos vendedores.
} 
termos, mudando apenas a hipótese de conhecimento perfeito, a qual gera os resultados neoclássicos. Tem-se, assim, conforme Chick (1983, p. 25, grifos no original):

(...) the power of Keynes argument: Keynes showed that, even taking the assumption of neoclassical analysis, he could produce non-neoclassical results. Monopoly elements then strengthen the argument, but the argument does not depend on them.

Como não há conhecimento e capacidade de previsão perfeitos e como a produção implica a destinação de recursos para um mercado no futuro incerto, as firmas não são tomadoras de preço para Keynes e o preço não é dado pelo mercado. O preço constitui representação da demanda nesse sistema. No modelo usual de pequena firma, quando o preço é determinado, há certeza plena da demanda e da possibilidade de venda àquele preço dado, sendo necessário decidir apenas a quantidade a ser produzida, a partir de custos, tecnologia e salários estabelecidos. A eliminação da hipótese de previsão perfeita exclui a possibilidade de conhecer de antemão os preços e a demanda, informações que devem ser coletadas a cada vez que há possibilidade de mudança. Segundo Chick (1983, p. 25), "Keynes insisted that the fundamental feature of production was the necessity of committing resources to production for a market which in the nature of things exists in the future and is therefore uncertain". A curva de demanda esperada estimada pela firma pequena ainda será horizontal, semelhantemente à curva de demanda do tomador de preços neoclássico ${ }^{56}$. A diferença é que a curva é baseada em expectativas sobre a demanda de mercado e as respostas de oferta das outras firmas ${ }^{57}$.

Também a curva de oferta individual da firma polipolística não deve ser entendida como conjunto de reações ao mercado. É um experimento mental no qual o produtor se pergunta sobre a oferta ótima frente a determinadas condições de demanda imaginadas, que são possibilidades constituídas por diversas curvas de demanda hipotéticas. Como os níveis de demanda que compõem a curva de oferta são puramente hipotéticos, a curva de

\footnotetext{
${ }^{56}$ Chick (1983) estipula que essa perspectiva quanto ao preço segue fórmula mais geral que permite avaliar também firmas com tamanho e poder de mercado significativos. Se a elasticidade da demanda não for desprezível, o preço pode ser definido como:

$$
P=\frac{|\eta|}{|\eta|-1} R M
$$

Em que: $P$ é o preço; $\eta$ é a elasticidade no ponto relevante; $R M$ é a receita marginal.

${ }^{57}$ Considerando que os consumidores são indiferentes aos produtos, se a firma definir preço acima daquele revelado como correto (pela previsão das outras firmas), a firma não venderá nada. Analogamente, se a firma fixar o preço abaixo do apurado no mercado, venderá tudo e mais estoques. Essas situações devem provocar mudanças na estratégia de preço e produção nos próximos períodos.
} 
oferta é completamente independente do nível de demanda esperada ou realizada ${ }^{58}$. Dessa forma, a curva de oferta da firma indica o nível de maximização de lucro da produção e do preço, considerados diversos níveis de demanda e o planejamento para acumular ou desacumular estoques de bens acabados. Esse resultado, acredita Chick, é uma estratégia geral, incorporada na curva de oferta, capaz de associar-se a qualquer expectativa de demanda específica ou qualquer porte de empresa, pequena ou grande ${ }^{59}$.

O estabelecimento do preço e da produção correspondentes depende da escolha de determinado nível de demanda esperada. Em conjunção com o nível da curva de oferta, é definido o nível de produção. Se o nível de produção pretendido equivaler ao nível realizado, ocorre situação que pode ser chamada de equilíbrio, a partir da qual não há incentivo a mudar, em períodos subsequentes, a expectativa de demanda. Se houver desapontamento quanto ao nível de produção realizado, no momento seguinte a firma deve escolher outro nível hipotético de produção.

$\mathrm{Na}$ agregação setorial, podem ser discernidos alguns supostos da firma com relação às respostas de oferta e preço das outras firmas. Chick (1983, p. 88) apura que a curva de demanda horizontal é adequada para a pequena firma não porque ela pode vender qualquer quantidade ao preço verificado, mas sim porque "if it prices low enough to sell anything, it can sell at least as much as it produces". Desse modo, a curva de demanda tornar-se-á negativamente inclinada a partir de certo ponto determinado pela curva de demanda do mercado e pela fatia de mercado da firma individual. Se, por exemplo, as firmas tiverem custos idênticos, as curvas de demanda individuais (que dependem dos tamanhos relativos das firmas) inclinar-se-ão para baixo no ponto de interseção com o custo marginal. A forma da curva de demanda individual da firma não depende de atitudes price-taking ou price-making, mas sim do tamanho relativo da firma, do grau em que as firmas do setor interpretam o mercado de maneira semelhante e do grau em que as firmas estabelecem os preços de maneira independente ${ }^{60}$. As inferências dos empresários podem não ser corretas, ainda que estimem acertadamente a demanda de mercado. Podem existir falhas de coordenação, principalmente em razão do conhecimento precário sobre a ação

\footnotetext{
${ }^{58}$ Ainda que esses níveis de demanda tenham características comuns adequação ao ambiente institucional no qual está inserida a firma.

${ }^{59}$ Chick (p. 1983) ressalta que "These two stages of decision-making, the formation of a general strategy and the taking of a specific decision, do not involve the actual level of demand. (...) Thus it is unambiguous that both the supply curve and the amount supplied are independent of actual demand."

${ }^{60}$ Chick (1983) ressalta que a exposição tradicional sobre a agregação de curvas de demanda individuais é inconsistente, uma vez que a soma de curvas de demanda horizontais não resulta em curva inclinada para baixo. Suposições adicionais coerentes sobre o comportamento da firma permitem análise teórica mais adequada e geral.
} 
das outras firmas, levando a oferta excessiva ou reduzida em virtude dos preços. A agregação setorial e da economia supõe que os produtores realizam inferências razoáveis sobre a expectativa da demanda e da estrutura produtiva e corrigem seus erros ${ }^{61}$.

No caso do investimento, essa decisão empresarial será informada pela possibilidade de inovar para reduzir custos e elevar o lucro, considerando determinados níveis imaginados de demanda em espaço de tempo que ultrapassa um período produtivo e está no contexto de expectativas de longo prazo. O investimento começará a será recuperado no futuro, a partir de quando entrará em operação. Também é significativo o fato de que lucro será obtido futuramente, ao passo que se incorre em custos no presente. Os ganhos com o investimento devem ser ponderados com o custo corrente do capital fixo, o resultado líquido frente à alternativa de emprestar a juros o montante de recursos disponível e o custo de eventual financiamento a ser contraído.

Na concepção de Keynes (1936, capítulos 11 e 12), a eficiência marginal do capital e os animal spirits desempenham função central na decisão de investimento ${ }^{62}$. investimento ou compra de cada ativo de capital corresponde ao direito a série de retornos futuros esperados durante o ciclo de vida desse bem, após as vendas e a dedução dos gastos com a produção. $\mathrm{O}$ ativo de capital é ofertado a determinado preço que induziria uma empresa manufatureira a produzir uma unidade adicional do bem. A eficiência marginal do capital constitui a taxa que equaliza o valor presente do fluxo de retorno esperado do ativo de capital a seu preço corrente de oferta. A eficiência marginal varia diretamente com a escassez dos bens de capital, o que significa, para Carvalho (1992), que Keynes utiliza noção marshalliana de quase-rendas advindas da posse do bem de

${ }^{61}$ A agregação da oferta, no nível setorial e da economia, está associada ao valor da receita que justifica a contratação de certo volume de emprego, mostra. Chick (1983). As dimensões de preço e quantidade trabalhadas na teoria da firma estão relacionadas com nível de emprego definido implicitamente. Já na agregação macroeconômica, utilizam-se as dimensões preço X quantidade e emprego. A curva de oferta setorial, que é escrita a partir da função de produção e é função explícita do emprego, pode ser apresentada como:

$$
Z_{i}=\frac{\left|\eta_{i}\right|}{\left|\eta_{i}\right|-1} \frac{w A_{i}}{Q_{i}^{\prime}} N_{i}
$$

Sendo: $N$, o nível de emprego; $Q^{\prime}$, o produto marginal físico do trabalho, derivado de $Q(N)$, o volume de produto em função de $N ; Z$, a oferta; $A_{i}=Q_{i} / N_{i}$, o produto médio do trabalho; $\eta$, a elasticidade da curva de demanda no ponto relevante; $w$, as unidades de salário. Os subscritos representam a firma $i=1 \ldots n$ na economia.

A agregação no nível da economia tem como fonte as decisões de oferta individuais, segundo a distribuição da produção. Keynes supôs, no capítulo 20 da Teoria Geral, que toda expansão ocorria no setor de bens de investimento. Outra maneira de simplificar é manter a distribuição setorial inalterada. A agregação no nível da economia, representada sem os subscritos, é mostrada como:

${ }^{62}$ Ver também Amado (2000).

$$
Z=\frac{|\eta|}{|\eta|-1} \frac{w A}{Q^{\prime}} N
$$


capital. As eficiências marginais de cada projeto e cada empreendedor podem ser comparadas de forma decrescente para gerar a curva de eficiência marginal do capital. Teoricamente, a taxa de investimento corrente real mover-se-á até o ponto em que não existe nenhuma classe de ativos de capital cuja eficiência marginal exceda a taxa de juros corrente, ou seja, até o ponto em que a curva de eficiência marginal se igualar à taxa de juros de mercado corrente ${ }^{63,64}$.

Essa eficiência marginal está definida em termos da expectativa de retorno e do preço de oferta corrente do ativo de capital, não do resultado histórico mostrado. Consequentemente, considerando o caráter prospectivo do preço de demanda dos ativos duráveis, Keynes (1936, p. 145) avalia que "The schedule of the marginal efficiency of capital is of fundamental importance because it is mainly through this factor (...) that the expectation of the future influences the present". Desse modo, a influência do investimento em bens de capital será decisiva para a expansão das firmas e para o nível de emprego na economia. Em especial, a existência de capital fixo será importante ligação entre o presente e o futuro, na qual escolhas estratégicas sobre este influenciam aquele. Keynes (ibid., p. 146) reconhece que:

It is by reason of the existence of durable equipment that the economic future is linked to the present. It is, therefore, consonant with, and agreeable to, our broad principles of thought, that the expectation of the future should affect the present through the demand price for durable equipment.

A base de conhecimento para a avaliação do rendimento esperado dos investimentos, no entanto, apresenta-se como precária ${ }^{65}$ em razão da incerteza, o que implica, na formação de expectativas de longo prazo, a consideração de ambiente associado a determinado estado de confiança (state of confidence) e ao comportamento convencional. A expectativa de longo prazo está vinculada, para Keynes, aos eventos futuros que podem ser previstos com mais ou menos confiança, como: mudanças futuras

63 A teoria da demanda por investimento de Keynes, indica Chick (1983, p. 118), “depends on distinguishing between the valuation of existing capital and the price at which new capital can profitably be produced, and between the rate of return on capital equipment and the rate of interest - things neoclassical theory often confuses".

${ }^{64}$ Cabe notar que nem sempre as firmas obterão muitos projetos de investimento a seu dispor, sendo vários dos quais marcados pela indivisibilidade, nem a avaliação objetiva será tão definitiva quanto a vontade de agir dos empreendedores.

${ }^{65}$ Keynes (ibid., p. 149) considera que "The outstanding fact is the extreme precariousness of the basis of knowledge on which our estimates of prospective yield have to be made. Our knowledge of the factors which will govern the yield of an investment some years hence is usually very slight and often negligible. (...) In fact, those who seriously attempt to make any such estimate are often so much in the minority that their behaviour does not govern the market". 
no tipo e na quantidade do estoque de ativos de capital e nos gostos dos consumidores; força da demanda efetiva ao longo do ciclo de vida do investimento; e variações na unidade de salários em termos monetários. Já que as expectativas de longo prazo dependem da melhor previsão possível e da confiança nessa previsão, Keynes entende que o estado de confiança estará vinculado, no comportamento de practical, assim como rational, economic men, ${ }^{66}$ a convenções atuais sobre o estado da economia. Assim, (ibid., p. 152):

In practice we have tacitly agreed, as a rule, to fall back on what is, in truth, a convention. The essence of this convention - though it does not, of course, work out quite so simply - lies in assuming that the existing state of affairs will continue indefinitely, except in so far as we have specific reasons to expect a change.

Apesar do comportamento convencional, e certa estabilidade das expectativas de longo prazo, as convenções estão sujeitas a alterações violentas, quando há motivos para desconfiar do estado de expectativas.

Nesse contexto de incerteza, as atividades empresariais no longo prazo não estão dissociadas das escolhas frente à aplicação da riqueza e à liquidez. Keynes separa os conceitos de especulação (speculation) e empreendimento (enterprise), relativos à previsão, respectivamente, da psicologia do mercado e dos rendimentos futuros. Ainda que o surgimento e a expansão de mercados secundários sejam importantes para melhorar a liquidez do investimento, a especulação aumenta com a organização dos mercados de investimentos e pode ser disruptiva se envolver em bolhas especulativas os empreendimentos. A liquidez dos mercados de investimento pode melhorar ou impedir novos investimento:

This is the dilemma. So long as it is open to the individual to employ his wealth in hoarding or lending money, the alternative of purchasing actual capital assets cannot be rendered sufficiently attractive (especially to the man who does not manage the capital assets and knows very little about them), except by organising markets wherein these assets can be easily realised for money.

Semelhante interpretação se encontra apresentada em maior profundidade no capítulo 17 da Teoria Geral, no qual é formulado modelo geral de escolha de ativos alicerçado nas

\footnotetext{
${ }^{66}$ Como já observado no capítulo 1, em que é ressaltada a formulação de Keynes (1937), o comportamento com base em convenções é considerado resposta racional à incerteza nas economias monetárias de produção.
} 
diferenças relativas de liquidez e retornos de capital (somados a eventuais ganhos de capital e líquidos de custos de carregamento), como discutido mais adiante.

Não obstante incerteza e dilemas, parece configurar-se, na economia, certa inclinação dos empreendedores para agir, no contexto do prognóstico futuro de lucros, mas não somente com base nessa avaliação. Se apenas o cálculo de lucros futuros fosse determinante para o investimento, poucos projetos teriam sido encetados. Os empresários mostram comportamento econômico em que se destacam capacidades e procura de eventuais oportunidades ${ }^{67}$, assim como, em muitos momentos, otimismo espontâneo. Principalmente, os empreendedores, explica Keynes (1936, p. 1961-63), ao invés de aferir média ponderada de benefícios multiplicados por probabilidades, são dotados de animal spirits, que constituem "a spontaneous urge to action rather than inaction" e apoiam grande parte das decisões de investimento. Desse modo, "individual initiative will only be adequate when reasonable calculation is supplemented and supported by animal spirits." Ainda assim, quedas e depressões tornam-se mais acentuadas com variações na atmosfera política e social ${ }^{68}$. A influência será significativa ao ponto de que "if the animal spirits are dimmed and the spontaneous optimism falters, leaving us to depend on nothing but a mathematical expectation, enterprise will fade and die; - though fears of loss may have a basis no more reasonable than hopes of profit had before". No entanto, Keynes aceita que a realidade não será formada por ondas de psicologia irracional. A racionalidade individual implica que:

human decisions affecting the future, whether personal or political or economic, cannot depend on strict mathematical expectation, since the basis for making such calculations does not exist; and that it is our innate urge to activity which makes the wheels go round, our rational selves choosing between the alternatives as best we are able, calculating where we can, but often falling back for our motive on whim or sentiment or chance.

As ações estratégicas na formulação e execução de empreendimentos no contexto da incerteza das atividades de negócios parecem constituir a base teórica da firma

\footnotetext{
${ }^{67}$ Keynes (1936, p. 150) não descarta apostas ousadas dos empreendedores: "Business men play a mixed game of skill and chance, the average results of which to the players are not known by those who take a hand. If human nature felt no temptation to take a chance, no satisfaction (profit apart) in constructing a factory, a railway, a mine or a farm, there might not be much investment merely as a result of cold calculation".

${ }^{68}$ Reconhece Keynes (1936, p. 1962) que "This means, unfortunately, not only that slumps and depressions are exaggerated in degree, but that economic prosperity is excessively dependent on a political and social atmosphere which is congenial to the average business man". Os humores dos empresários, inclusive em decorrência de descontentamentos com o grupo político no poder, podem implicar redução no nível de investimento e de atividade econômica.
} 
produtiva para Keynes, assim como se apresentam como fundamentais as restrições monetárias e financeiras ao comportamento desse agente econômico.

\subsubsection{Contribuições pós-keynesianas para teoria da firma}

As contribuições teóricas de Keynes, principalmente quanto à incerteza, serão importantes para trabalhos posteriores na teoria da firma. Autores como King (2008) avaliam que a microeconomia pós-keynesiana se apresenta relativamente pouco desenvolvida em comparação com a macroeconomia, por razões metodológicas como a compreensão de que não haveria necessidade de microfundamentos para a macroeconomia. Ainda assim, parecem existir formulações analíticas microeconômicas importantes, em especial para a concepção de firma. Os pós-keynesianos dirigem críticas também à microeconomia neoclássica, entre as quais: a modelagem de equilíbrio; a eliminação da incerteza por meio da definição de magnitudes equivalentes a uma posição de certeza; e a confiança em agentes idênticos ou representativos, ao invés de heterogêneos.

Assim como na macroeconomia, King (2008) afirma que os pós-keynesianos estão preocupados, na microeconomia, com o mundo real e a explicação de fatos estilizados. Esses autores se endereçam mais à firma oligopolista, não ao mundo considerado imaginário da concorrência perfeita. Assim, na teoria dos preços, autores como Lee (1999) observam mercados oligopolistas, utilizando a perspectiva dos preços administrados. Já a teoria do consumidor seria ainda incipiente. Contudo, na síntese de teoria do consumidor proposta por Lavoie (2014), é conferida mais ênfase nos efeitos renda do que os de substituição, bem como os axiomas neoclássicos de escolha racional são trocados pela teoria das preferências lexicográficas. Nessa perspectiva, hábito, costume e convenções sociais são restrições importantes sobre o comportamento individual, enquanto a escolha individual segue ordenamento de bens conforme hierarquia baseada na satisfação de necessidade humanas, em que o aumento da renda implica elevação na hierarquia.

Lavoie (2014) conclui que contribuições de diversos autores ${ }^{69}$ configuram uma perspectiva pós-keynesiana da teoria da firma comum desde a década de 1960. Essa

\footnotetext{
${ }^{69}$ Entre os quais, além de Eichner e Penrose, cita: Kaldor, Robinson, Kalecki, Steindl, Harrod, Andrews, Brunner, Means, Lanzilotti, Galbraith, Baran, Sweezy e Lee.
} 
abordagem utiliza elementos teóricos distintos daqueles presentes em Keynes (1936), ao apresentar princípios de poder de monopólio e preços administrados à análise. A característica comum entre eles é o reconhecimento de que os preços definidos pelas firmas no curto prazo não são equilibrados pelo mercado (market-clearing), mas sim administrados pelas firmas ${ }^{70}$, o que constituiria distinção fundamental frente à teoria neoclássica. De acordo com essa abordagem, a definição de megacorp utilizada por Eichner (1976) conformaria base para a visão pós-keynesiana da firma na economia contemporânea $^{71}$. Essa firma tem como características a grande dimensão, a administração separada da propriedade, custos marginais aproximadamente constantes e operação da firma em pelo menos uma indústria oligopolista ${ }^{72}$.

Cabe notar também que a concorrência para os pós-keynesianos, segundo Lavoie (2014), não seria observada tanto via preço, mas principalmente por meio dos custos, em que se busca a redução dos custos unitários e a expansão das margens de lucro frente às dos concorrentes, em especial por meio de inovações. Observar-se-ia visão da concorrência próxima da perspectiva neoschumpeteriana e evolucionista, com diferenciação da qualidade e valor dos bens e dos métodos de produção, bem como distinções nas capacidades das firmas, como na inovação em produtos e processos. $\mathrm{O}$ caráter dinâmico da concorrência não estaria associado apenas à competição via preço, que achata margens e leva a falências, comportamentos arriscados e piora na qualidade de produtos. Assim, embora o valor atribuído à concorrência seja ambíguo para os póskeynesianos, destaca Lavoie, essa concorrência não seria ótima ou eficiente.

Além da discussão sobre o porte e a estrutura de custos ou mercados, a preocupação analítica com o comportamento em uma economia monetária de produção afigura-se como central na perspectiva pós-keynesiana da firma. Como proposto por

\footnotetext{
${ }^{70}$ Existe divergência quanto à formação de preços, se ocorreria em situação de oligopólio ou de pequenas firmas. Ainda assim, a existência de preços administrados, por meio da regra de mark-up a partir dos custos (verificada empiricamente desde o estudo clássico de Hall e Hitch, 1939), seria disseminada na prática em diversas estruturas de mercado.

${ }^{71}$ Shapiro (2011) atribui também importância destacada à formulação de Galbraith (1967), para quem a grande empresa industrial moderna seria capaz de mobilizar recursos suficientes para desenvolver dinâmica e estrutura próprias. A escala e o poder de mercado da grande empresa industrial ensejariam maior financiamento para inovação, ao mesmo tempo em que a existência de barreiras à entrada diminuiria riscos para o investimento de longo prazo. A base de capital elevada e a organização de trabalhadores especializados em tecnoestrutura vinculada à empresa sustentaria as conquistas da grande empresa no crescimento e no desenvolvimento tecnológico.

72 O papel da grande empresa industrial para o crescimento é enfatizado por Eichner (1976). O tamanho e o poder de mercado fornecem e asseguram financiamento suficiente, o que é primordial para o investimento de longo prazo. A organização corporativa dessa empresa é central também para o investimento, ao estarem separadas a gerência e a propriedade, garantindo-se gestão profíssional.
} 
Carvalho (1992), o princípio da produção nas economias monetárias associa-se especificamente ao comportamento das firmas. A particularidade da firma como agente econômico implica o reconhecimento de que esse agente tem atividades exclusivas e motivos e objetivos diferentes de outros agentes na economia, como as famílias. Como já apresentado, a firma produz para obter lucros, não gerar utilidade para outros. Carvalho (1992, p. 44) define que "The firm exists (...) to accumulate wealth and its 'satisfaction' is reached when it is able to increase the command it has over wealth." Essa acumulação é de riqueza em geral, o que toma a forma de moeda ${ }^{73}$.

Também a consideração de que a economia monetária é regida por um princípio de estratégia dominante ressalta a importância das firmas, que se situam em posição hierárquica superior frente a outros agentes. O montante de emprego e de poupança depende das decisões das firmas de produzir e investir, enquanto os trabalhadores e os poupadores se adaptam às decisões daqueles agentes. Os bancos são centrais no processo de financiamento do investimento. Carvalho explica que essa hierarquia existe por que a distribuição dos recursos produtivos é desigual na economia, uma vez que o capital, para Keynes, é considerado escasso em relação ao trabalho. O controle dos meios de produção, dessa maneira, não é igualmente acessível aos agentes na economia.

Cabe notar que o motivo do lucro, nas discussões entre os pós-keynesianos, pode estar relacionado com outros objetivos, ainda que não pareçam substituir a noção de que o fundamento da firma é realmente obter mais lucros, em associação com outros elementos de crescimento ou poder. Autores como Lavoie (2014) argumentam que o principal objetivo da firma seria aumentar seu poder sobre o ambiente em que atua, seja econômica, social ou politicamente. Esse objetivo independeria, na verdade, da propriedade e do tamanho e não seria a maximização de lucros. Os lucros constituiriam um meio para atingir esse objetivo. Dessa forma, há o desejo de exercer maior grau de controle sobre eventos futuros, restrições financeiras, qualidade da mão de obra, preços no setor ou possibilidade de realização de fusões e aquisições. Esse objetivo seria alcançado por meio do crescimento da firma, o que se coadunaria com a perspectiva avançada por Penrose (1959). A firma, para satisfazer esse objetivo, não está imune a

\footnotetext{
${ }^{73} \mathrm{O}$ indicador de poder de compra para comparar a riqueza é o salário monetário, que mede o comando sobre a riqueza real ou o poder para gerar riqueza real representada por certa quantidade de moeda. Carvalho (1992, p. 45) entende que "Specific goods may be meaningful indices in specific sector, but only labour is of interest to all firms and that is why the money wage is the most strategic price for the decisions of firms as a whole".
} 
restrições ao crescimento. Os lucros permitem que a firma cresça, mas podem depender também de restrições financeiras ${ }^{74}$.

Nas economias monetárias de produção, as firmas, ao buscarem o lucro, estão associadas a capacidades, recursos e decisões frente à concorrência e à incerteza. Feijó (1993) propugna que a firma, na visão pós-keynesiana, é identificada como instituição que controla ativos produtivos e que pode absorver recursos da comunidade por meio do mercado financeiro, para colocá-los em ação ou expandir a capacidade produtiva. Verifica-se a transformação tanto de recursos reais em produto quanto de recursos financeiros, sendo a eficiente administração desses recursos o que assegura a sobrevivência da firma no longo prazo. A firma pós-keynesiana pode operar com várias plantas e em diversos mercados, bem como diversificar aplicações em mercados financeiros, embora mostre principal preocupação com atividades produtivas e de investimento, no caso da empresa industrial em concorrência imperfeita. A sobrevivência dessa organização, em meio à concorrência, está associada ao crescimento, enquanto seu principal objetivo é produzir para aumentar lucros monetários e, em consequência, o potencial de crescimento. Desse modo, a interação da firma com o ambiente externo é determinante para a trajetória de crescimento, considerando a incerteza e o caráter irreversível do tempo histórico.

Nessa perspectiva, as noções essenciais de recursos, crescimento e de estratégia encontram-se presentes em diversas formulações. Com base na preocupação de Penrose (1959) com o crescimento da firma, distingue-se a firma industrial como organização administrativa que representa conjunto de recursos produtivos, tanto humanos quanto materiais, para a produção de bens e serviços de acordo com planejamento desenvolvido internamente. Assim, "a firm is more than an administrative unit; it is also a collection of productive resources the disposal of which between different uses and over time is determined by administrative decision" (ibid., p. 21). As competências desenvolvidas pela firma não estão apenas nos indivíduos, mas são dependentes do contexto organizacional. Esses recursos produtivos são heterogêneos e conferem singularidade a cada firma ${ }^{75}$.

\footnotetext{
${ }^{74}$ Assim, Lavoie (2014, p. 135) defende que "The consensus opinion among post-Keynesians is that profits are the means which allow firms to grow. By financial necessity, profits cannot be disconnected from investment and growth. The growth objectives set by the decision makers are constrained by the financial requirements of profitability, past and expected".

${ }^{75}$ Escreve Penrose (1959, p. 67) que "It is the heterogeneity, and not the homogeneity, of the productive services available or potentially available from its resources that gives each firm its unique character".
} 
A hierarquia proveniente de uma administração central é base para o planejamento dentro da organização administrativa, tornando a firma essencialmente distinta do mercado. Quanto maior for o crescimento da firma, a unidade administrativa industrial será mais importante, para diminuir a extensão da alocação de recursos diretamente pelas forças de mercado e aumentar o escopo para o "conscious planning of economic activity" "76. A firma irá maximizar seu crescimento, o qual está vinculado ao motivo de buscar lucros. Crescimento e lucros se tornam equivalentes, considerando a política de investimento no longo prazo. Assim, "investment decisions are guided by opportunities to make money; in other words that firms are in search of profits", bem como "profits would be desired for the sake of the firm itself and in order to make more profit through expansion" (ibid., p. 24 e 26).

A influência das expectativas apresenta-se como determinante para os póskeynesianos, Penrose (ibid., p. 37) explica que:

'Expectations' and not 'objective facts' are the immediate determinants of a firm's behaviour, although there may be a relationship between expectations and 'facts'indeed there must be if action is to be successful, for the success of a firm's plans depends only partly on the execution of them and partly on whether they are based on sound judgment about the possibilities for successful action.

O comportamento da firma está associado à noção de estratégia em uma economia monetária incerta, assim como fora observado em Keynes. Shackle (1970, p. 20) define que "The essence of the firm is that here production is designed. (...) The concept of the firm is that of a centre of policy-making, of decision or policy-revision, and of management or policy execution". As decisões do empreendedor estão atreladas à incerteza e ao tempo, em que não há como saber com exatidão as consequências das ações tomadas. Não obstante, o empreendedor não é apenas uma vítima da incerteza, mas também, a todo o tempo, cria racionalmente, com seus atos, mais incerteza, ao introduzir mudanças no curso da história e modificar a base de conhecimento existente na sociedade, em meio à concorrência e à interação com outras firmas. Assim, o autor (ibid., p. 22-23) exprime que:

\footnotetext{
${ }^{76}$ Penrose (1959, p. 14) afirma que "the industrial administrative unit is of importance because the larger this unit is, the smaller is the extent to which the allocation of productive resources to different uses and overtime is directly governed by market forces and the greater is the scope for conscious planning of economic activity". A autora ainda observa que "All such units have some form of central managerial direction responsible for the general policies under which the firm's administrative hierarchy operates. Let us call this 'court of last resort' in the firm 'central management'."
} 
The businessman desires, and strives, to gain advantage over his rivals by innovation, by novelty in products or technology. The fact that a field for such innovation exists is itself a proof that business uncertainty is inescapable. Businessmen compete with each other largely by policies which directly create uncertainty. Innovation is the chief means of business success. There is in consequence a compulsion upon businessmen to search for possibilities of innovation and thus to bring about the continual evolution of society's productive system as a whole.

Entre as estratégias e as escolhas associadas, o investimento adquire caráter fundamental para o comportamento da firma. Os programas de investimentos, por sua inovação, indivisibilidade e irreversibilidade, não raro se apresentam como eventos ou experimentos cruciais, na acepção de Shackle (1970, p. 109). Inexiste forma de obter referências relevantes e calcular probabilidades de êxito quando há a incorporação de "novelty of technique or product in a plant which must be built and operated as a whole on a scale costing an appreciable part of the firm's entire resources". Nesse sentido, Shackle entende que:

\begin{abstract}
Above all, how can such a probability have meaning for a firm which can only build such a plant once in twenty years? Such an investment has something of the character of a crucial experiment, one whose repetition is logically impossible because its very performance destroys for ever the conditions in which it was undertaken, which form an essential part of it. Novelty does not remain novel. Once illustrated in practice, an invention can be imitated. The ignorance or distrust of a new technique, once banished from the minds of a firm's rivals, can never be restored. The success of the investment may set the firm on the road to a vast expansion, or its failure may ruin the firm. These results are not reversible. The firm has a personal identity, large-scale events which happen to it are, from its viewpoint, each essentially unique. The firm needs a scheme of thought quite different from that of averaging the things that have happened to others; it needs a scheme which places in a strong light the worst that 'can' happen to itself, through the adoption of this investment-programme or that.
\end{abstract}

Mais especificamente, a implementação das decisões implica sequência de eventos, uma vez que, conforme Feijó (1993), a atividade produtiva configura “ordenação de processos complexos" ao longo do tempo. Verifica-se comprometimento gradual de recursos que serão remunerados apenas ao fim da sequência. A consecução do plano e a herança de planos anteriores constituem restrições às ações, dada a irreversibilidade do tempo. Nesse processo, a formação das expectativas, de curto e longo prazos, será determinante nas escolhas e ações dos empresários. Os empreendedores estabelecerão planos de investimento com base nas expectativas de longo prazo e na consideração dos recursos internos e externos A realização das expectativas de curto prazo pode aumentar 
o grau de confiança na economia, já que a implementação de planos de longo prazo é realizada por meio de atividades no curto prazo $^{77}$. Para o crescimento da firma, a forma de obter fundos no curto prazo para financiar planos de investimento torna-se fundamental e fornece exemplo de interação entre curto e longo prazo.

Na teoria pós-keynesiana, nota Feijó (ibid.), as decisões de preço estão associadas ao investimento, por causa do objetivo de, pelo menos em parte, reter lucros para a expansão, bem como da necessidade de honrar dívidas contraídas com recursos externos. $\mathrm{Na}$ decisão de preço está contida escolha também sobre a taxa de crescimento da firma. Em situação de incerteza, os empresários podem escolher uma taxa de retorno sobre determinado volume de produto, correspondendo à fixação de um mark-up. De acordo com Eichner (1976, p. 2-3):

In the oligopolistic pricing model (...), a change in the industry price level is held to be a function, costs remaining constant, of a change in the rate of growth of investment relative to the rate of growth of internal funds generation. Put another way, prices in the oligopolistic sector are set not to maximize short-run profits but rather to enable the firms in that sector to finance the level of investment necessary to maximize - or at least move further toward maximizing - their own long-run growth.

O preço determinado pelas firmas deve ser considerado como estratégico, uma vez que embute também o aspecto financeiro e a dinâmica de concorrência no mercado. Ainda que os empresários queiram preços maiores para financiar o investimento, devem defini-los de modo que desestimulem ou erijam barreiras à entrada de concorrentes (mesmo que uma baixa elasticidade da demanda permita elevações de preço), além de atuar de acordo com o nível de maturidade dos mercados ${ }^{78}$.

Feijó (1993) identifica, na teoria pós-keynesiana, ênfase no estudo das decisões de acumulação de ativos de capital fixo, que compreendem a máquinas e equipamentos e plantas industriais, que são menos líquidos e têm com duração continuada por diversos períodos produtivos. A escolha sobre a alocação dos recursos para investimento depende

\footnotetext{
${ }^{77}$ Não obstante a formação das expectativas de longo prazo seja independente das de curto prazo, estas últimas podem influenciar o grau de confiança daquelas expectativas. A divergência entre os valores de curto e de longo prazos pode gerar interpretação de que foi inadequada a decisão tomada, levando a mudanças entre as posições de curto prazo.

${ }^{78}$ Para Feijó (1993), o grau de maturidade dos mercados também influencia na decisão de preço. Mercados maduros mostram pequena quantidade de firmas dominantes com capacidade produtiva em excesso com relação ao mercado, como resultado da concorrência via expansão da produtividade e da capacidade. A competição por meio do preço é mitigada entre as firmas sobreviventes, que se dedicam à diferenciação de produtos e, para tanto, se utilizam de mark-ups mais altos. No entanto, a atuação em mercados mais maduros relaciona-se com ritmo de crescimento mais limitado, apesar dos mark-ups maiores, gerando incentivo para diversificação em direção a mercados novos, nos quais a competição via preço é mais importante.
} 
da avaliação da firma sobre ganhos futuros. O ritmo dos investimentos em ativos fixos vai depender do grau de confiança no futuro para investir em ativos menos líquidos. As expectativas sobre a lucratividade futura de aplicações e a preferência pela liquidez, portanto, são determinantes para os planos de investimento. A firma decidirá trajetória de crescimento com base nos recursos de que dispõe e na percepção sobre o ambiente externo.

No caso dos recursos, diferentes ações podem ser direcionadas de acordo com a decisão sobre utilizar recursos internos ou externos em planos de investimento que comprometem recursos financeiros hoje diante de um futuro incerto. $\mathrm{Na}$ escolha entre a acumulação interna de fundos e a obtenção de recursos externos, a firma decidirá em função dos custos incorridos em cada modalidade. Os recursos internos ${ }^{79}$ podem advir da poupança interna e de formas de reorganizar a produção de maneira mais intensa ou lucrativa, ou ainda por meio da diversificação de atividades, com produtos derivados e outros tipos de produção conjunta.

O motivo financiamento (finance), que foi desenvolvido por Keynes no debate com Bertil Ohlin em $1937^{80}$, está relacionado com a demanda antecipada por dinheiro face a despesas discricionárias planejadas, principalmente investimento em bens de capital. São gastos menos rotineiros e de grande monta, requerendo um provimento financeiro em forma de saldos monetários inativos. Dessa maneira, os agentes, ao planejarem uma compra de bens de investimento, devem antecipar estes saldos através da venda de bens e serviços ou de ativos líquidos ou ainda via empréstimos junto aos bancos. Esta retenção de fundos é provisória, pois quando é realizada a compra do bem de capital parte do dinheiro volta à circulação monetária, ficando parte nos bancos, constituindo-se assim um fundo rotativo. O investimento ex ante é suprido em boa parte pelos recursos do financiamento ex post. Por conseguinte, este motivo é definido em função do investimento na economia; se, por exemplo, a taxa de investimento estiver aumentando, mais dinheiro será demandado.

Os recursos externos exercem influência nas decisões de investimento mediante alterações no nível de endividamento da firma ou na necessidade de pagar dividendos. Os

\footnotetext{
79 Os fundos internos, advindos das decisões de preço, dependem das condições de demanda e de concorrência e podem ser baixos devido à concorrência ou podem implicar perda de posição de mercado. ${ }^{80}$ Ver em Keynes (1987a): Alternative Theories of the Rate of Interest (p. 201-15) e The Ex Ante Theory of the Rate of Interest (p. 215-23).
} 
recursos serão combinados segundo proporção considerada segura, ainda que de maneira subjetiva, pela firma ${ }^{81}$.

O perfil do fluxo de caixa, para que se mantenha a liquidez considerada adequada pela empresa, confirma, segundo Feijó (1993), o contexto no qual a decisão de investimento deve ser considerada também uma decisão de portfólio ${ }^{82}$. A decisão de investir, relacionada às expectativas de longo prazo sobre um futuro incerto, pode ser embargada pela falta de interesse em comprometer recursos financeiros em atividades produtivas. No curto prazo, interrupções e atrasos na implementação de projetos de investimento podem ocorrer devido a aumentos na incerteza e diminuição da confiança nas expectativas de longo prazo. Os investimentos em ativos fixos podem ser deslocados para investimentos financeiros mais líquidos. Embora o investimento em atividades produtivas não deva ser adiado indefinidamente, no caso da firma industrial, os planos de investimento podem ser repensados, considerando-se a ocorrência de mudanças no ambiente externo no contexto de tempo histórico.

As condições de financiamento são centrais para os pós-keynesianos, pois podem atuar como estímulo ou restrição ao investimento em ativos fixos. No caso de recursos externos, o financiamento via empréstimo bancário ou de outras instituições financeiras tem implicações importantes para as firmas. A dívida nova compromete receitas futuras e incertas frente a pagamentos certos durante determinado período de tempo, aumentando o risco do tomador de empréstimo. O empréstimo ainda está sujeito às condições do emprestador e da avaliação subjetiva deste quanto ao passivo da firma. Os bancos e instituições financeiras estarão mais dispostos a aceitar maior nível de endividamento dos emprestadores quando as expectativas estiverem mais otimistas, ocorrendo o inverso por ocasião de cenário pessimista. As firmas, desse modo, procuram escolher o nível de endividamento conforme esse contexto.

Minsky (1975, p. 84) considera que a atitude das firmas frente ao endividamento constitui forma de especulação na economia. Apesar do futuro incerto, aposta-se na possibilidade de realizar os pagamentos:

\footnotetext{
${ }^{81}$ De acordo com Lavoie (2014), é importante na discussão pós-keynesiana, desde a noção de risco crescente de Kalecki (1937), a proporção de recursos internos e externos e a fronteira ou restrição de financiamento. No caso de empréstimos, o custo explícito é taxa de juros para a firma, que pode tornar-se insolvente. Já o lançamento de ações gera a necessidade de pagar dividendos e pode resultar em perda de controle administrativo.

${ }^{82}$ No caso da utilização de recursos internos, por exemplo, a acumulação relaciona-se com a mudança na composição de portfólio da firma, realocando recursos de ativos financeiros (como moeda) para o novo projeto.
} 
Liabilities (debts) are issued to finance-or pay for-positions in owned assets; for operating firms the plant and equipment are the owned assets. The liabilities set up dated, demand, and contingent cash-payment commitments. Each firm speculates when it undertakes such commitments. As it undertakes these commitments the firm envisages situations in which the payments can be met, as well as others in which they cannot be met or can be met only at a substantial cost. The firm in accepting a liability structure in order to hold assets is betting that the ruling situation at the future dates will be such that the cash payment commitments can be met: it is estimating that the odds in an uncertain future are favorable.

As posturas financeiras exercem papel significativo na dinâmica das firmas, de acordo com Feijó (1993). A necessidade de recursos varia ao longo da implementação dos projetos de investimento, como decorrência da disponibilidade de fundos externos e da confirmação das expectativas quanto à geração de fundos internos. Nesse processo de implementação, são importantes a estrutura administrativa e a estrutura financeira da firma. Para Minsky (1982, 1986), na análise do balanço da firma, é importante o perfil das receitas e das despesas ao longo do tempo. Os pagamentos de juros e impostos e a remuneração de sócios vêm da renda bruta de capital (a receita total menos os gastos com mão de obra e insumos). Três perfis, hedge, especulativo e Ponzi, podem ser adotadoss pela firma de acordo com a estratégia de portfólio e a renda bruta de capital. Em determinado período de tempo, a postura hedge mostra fluxo de caixa esperado maior do que os pagamentos relativos à dívida, sendo a mais independente de flutuações. $\mathrm{O}$ comportamento especulativo cobrirá apenas os juros em certo período, podendo reequilibrar-se para pagar o principal se conseguir mais recursos no futuro. A postura Ponzi não tem fundos para cobrir os juros, aumentando o montante de dívida. Flutuações na economia e na renda bruta podem gerar níveis diferenciados de vulnerabilidade e instabilidade nas firmas.

Embora possam existir distinções entre as contribuições, as noções sobre as capacidades da firma como centro de estratégia em uma economia monetária produção parecem comuns no âmbito da teoria pós-keynesiana. São consideradas relevantes a estratégia, a concorrência, a utilização de recursos e as decisões financeiras. As firmas precisam desenvolver capacidades para lidar com o ambiente econômico no contexto de incerteza.

\subsubsection{Ativos e investimento nas economias monetárias de produção}


A determinação do investimento, para Keynes e os pós-keynesianos, é essencial para o entendimento das flutuações e do desenvolvimento na economia. O montante de emprego que os empreendedores pretendem utilizar depende do ponto de demanda efetiva, que é a soma dos gastos esperados com bens de consumo, que dependem da lei psicológica da propensão a consumir ${ }^{83}$, e com bens de investimento ${ }^{84}$, que dependem das ações dos empreendedores. O consumo representa proporção da renda gerada e não permite sozinho atingir o pleno emprego. O investimento constitui a principal variável que permite reduzir a distância frente à utilização plena de fatores ou recursos da economia. A maneira como os agentes alocam a riqueza será determinante para a alocação de recursos em bens de capital. Keynes e os pós-keynesianos enfatizam estes investimentos e reconhecem a importância de diminuir a escassez de bens de capital.

Os ativos constituem direito sobre renda futura. Keynes (1936, capítulo 7) enfatizou que é possível para um indivíduo elevar sua poupança ao comprar tanto ativos novos, recém-criados, quanto antigos. Se um novo ativo for criado, ocorre investimento de fato, o que conforma caso relevante para a acumulação de capital. Se for comprado ativo já existente, a poupança do indivíduo equivale à despoupança de outro agente ${ }^{85}$. Como apresentado anteriormente, os ativos direcionados à inovação e ao aumento de capacidade no processo produtivo adquirem relevância para a firma produtiva.

Keynes (1936), no capítulo 17 da Teoria Geral, descreve uma perspectiva geral da escolha sobre o emprego da riqueza e elabora teoria de escolha de ativos, como apontam Chick (1983) e Carvalho $(1992)^{86}$, definindo o status de ativo do dinheiro perante os outros $^{87}$. Cada ativo tem uma taxa própria de juros (own-rate of interest), que é calculada segundo o preço corrente (spot) do ativo e seu preço futuro (forward) esperado, defínido

\footnotetext{
${ }^{83}$ De acordo com Keynes (1936, cap. 8 e 9), o consumo agregado não representa a decisão de consumir hoje ou amanhã, mas sim o conjunto específico de hábitos, da cultura, da sociedade. Existem características objetivas e subjetivas da propensão a consumir que, apesar de estarem sujeitas a mudanças, são razoavelmente estáveis no curto prazo e determinam uma propensão marginal a consumir menor do que a unidade.

${ }^{84}$ Pela definição de Keynes (1936, cap. 7), não é necessário haver poupança prévia para financiar o investimento. A poupança é o que sobra da renda menos o que não é gasto com consumo, então a determinação da poupança, que é sempre igual ao investimento em termos agregados, é definida ex post, após a determinação do investimento, que propicia a definição do nível de renda.

${ }^{85}$ Para Keynes, o investimento agregado não está restrito à poupança, mas, de fato, gera igual montante de poupança agregada ex post, via efeito multiplicador, já que a poupança é determinada pelo nível de renda.

${ }^{86}$ Para Carvalho (1992, p. 93), “The model of own-rates of interest is (...) the heart of Keynes's and Post Keynesian macroeconomics because it is the general model from which the more specific theories of liquidity preference and the marginal efficiency of capital will be derived"."

${ }^{87}$ Essa noção de preferência pela liquidez mais abrangente, preferida por diversos autores pós-keynesianos, como aponta Carvalho (1992), contrasta com a formulação restrita de demanda por moeda presente no capítulo 15.
} 
pelos valores esperados dos quatro atributos que cada ativo i possui em maior ou menor grau, ao longo de determinado período de tempo:

a) Taxa de retorno ou produto $\left(q_{i}\right)$ : rendimentos proporcionados pelo ativo por meio de algum processo de produção ou suprindo serviços a um consumidor;

b) Custo de carregamento $\left(c_{i}\right)$ : devido a desperdício ou algum custo envolvido com a posse do ativo no tempo, independente do seu rendimento (sendo mais significativo considerar a relação combinada $\left.q_{i}-c_{i}\right)$;

c) Prêmio de liquidez $\left(l_{i}\right)$ : relaciona-se à segurança que confere o ativo para ser negociado com facilidade e conservar seu valor.

d) Apreciação esperada $\left(a_{i}\right)$ : refere-se a ganhos (ou perdas) de capital, ou seja, a variação do preço de mercado do ativo no final do período considerado.

Dessa maneira, a taxa própria de juros $\left(r a_{i}\right)$, ou retorno esperado total, de cada ativo é determinada pela equação:

$$
r a_{i}=a_{i}+q_{i}-c_{i}+l_{i}
$$

Em equilíbrio, os rendimentos esperados a serem obtidos pelos proprietários dos ativos (não-monetários) devem ser iguais à sua liquidez relativa quando comparados ao dinheiro, de modo a igualar as vantagens marginais entre os ativos. Os preços se moverão até que as vantagens relativas de um ativo sobre qualquer outro desapareçam. Em termos da fórmula da taxa própria de juros, para aqueles ativos que oferecem melhores retornos prospectivos, os preços correntes (que são o denominador de todos elementos) aumentarão até que $a_{i}$ e $q_{i}-c_{i}$ sejam então reduzidos, de forma que os ganhos extras, que eram antecipados, desapareçam. $\mathrm{O}$ oposto ocorre com ativos de baixo rendimento: os preços caem de forma que os valores de $a_{i}$ e $q_{i}-c_{i}$ se elevem.

Com base nessa concepção, é possível classificar os ativos em conformidade com seus rendimentos, custos de carregamento, taxa de apreciação e liquidez. Ativos com diferentes prêmios de liquidez devem fornecer retornos monetários para compensar a iliquidez relativa medida frente ao ativo de referência. A composição da demanda por ativos na economia reflete, em equilíbrio, a preferência dos agentes por combinações entre liquidez e retornos esperados. A preferência pela liquidez será definida segundo o tradeoff entre retornos esperados $\left(a_{i}+q_{i}-c_{i}\right)$ e o prêmio de liquidez $\left(l_{i}\right)$. O dinheiro tem o maior prêmio de liquidez entre os ativos, ao passo que não apresenta rendimento. 
Os bens de capital estão entre os menos líquidos, enquanto os ativos financeiros (como títulos de dívida pública) que possuem um mercado secundário desenvolvido estão mais próximos da (alta) liquidez do dinheiro. O atributo da liquidez é mais apreciado quando há um aumento da incerteza.

Quando as expectativas dos agentes estão otimistas e a incerteza é baixa, o atributo de liquidez não deve ser tão importante quanto a possibilidade de auferir ganhos monetários. A taxa própria de juros de ativos líquidos torna-se mais baixa do que as taxas próprias daqueles ativos cujos ganhos são maiores em $a_{i}$ ou em $q_{i}-c_{i}$, como os bens de capital. Os agentes econômicos devem abrir mão do dinheiro para obter bens de investimento, cujos preços spot se elevarão e estimularão nova produção. Alternativamente, se a incerteza for alta, o prêmio de liquidez do dinheiro será provavelmente mais elevado do que os rendimentos monetários oferecidos para outros ativos, como bens de capital e títulos. Com maior incerteza, os agentes tentarão manter portfólios líquidos, deprimindo os preços de ativos como bens de capital e levando a uma contração no setor produtor desses bens.

Ainda que a escolha da alocação da riqueza possa ser dirigida a ativos mais líquidos, os bens de capital, como observado anteriormente, são determinantes para as estratégias de expansão e o funcionamento das firmas. Carvalho (1992), a partir do modelo de escolha de ativos, salienta a noção mais geral, advinda desse modelo, de como a eficiência marginal do capital deve igualar-se à taxa de juros. O excesso de rendimentos em moeda esperados dos bens de capital frente aos títulos deve equivaler ao excesso de risco que aqueles bens representam relativamente ${ }^{88}$. No caso do capital fixo, a duração maior, as indivisibilidades e a especialização quanto ao uso tornam esses bens muito ilíquidos. A estratégia de acumulação é arriscada e precisa ser induzida por expectativas otimistas sobre o futuro das quase-rendas associadas a esse investimento.

Nesse sentido, as expectativas e a ação frente à incerteza revelam-se novamente dominantes na estratégia de acumulação. Como notado em Keynes, o investimento responde às expectativas de longo prazo, associadas a determinado estado de confiança convencionalmente seguido sobre os rendimentos dos ativos. Ainda assim, as suposições

\footnotetext{
${ }^{88}$ Denominando k o bem de capital e b certo conjunto de títulos financeiros (mas com notação distinta), a situação de equilíbrio é estabelecida com igualação das taxas internas de juros dos dois ativos $\left(r a_{k}=r a_{b}\right)$. Rearranjando os termos, obtém-se a relação que indica como os rendimentos esperados dos bens de capital devem exceder a diferença entre o prêmio de liquidez de cada um: $\left(a_{k}+q_{k}-c_{k}\right)-\left(a_{b}+q_{b}-c_{b}\right)=l_{k}-l_{b}$
} 
sobre o rendimento futuro são "figments, not facts", como ressalta Shackle ${ }^{89}$. Os animal spirits dos empreendedores, ao impulsionarem a ação, funcionam complementarmente à avaliações sobre os rendimentos esperados, salienta Carvalho (1992, p. 122):

So the decision to act based on these consciously known, imperfectly informed expectations will depend on how confident the agent is about them; in other words, on how significant is the weight of the evidence from which the expectations were formed. This is where 'animal spirits' come into play. Considerations of animal spirits is not contradictory per se with calculations. It refers to the course of action that will be chosen on the basis of these calculations. Its relevance is in making it possible for an agent to act even if the weight of the evidence he possesses is small. If he is confident about his power to identify sequels and relevant influences in the future, he will act even if the objective knowledge basis on which the decision is sustained is slight.

O financiamento e as variáveis financeiras têm papel importante no investimento em bens de capital, principalmente a taxa de juros e a questão da disponibilidade de fundos, destaca Carvalho (1992). A disponibilidade depende da disposição e das condições das instituições financeiras para prover recursos a determinado plano de investimentos. A taxa de juros é variável importante para estabelecer o preço de demanda dos ativos, o qual é derivado do valor presente dos rendimentos esperados, mas também é significativa para o custo de empréstimos ${ }^{90}$. A influência da taxa de juros torna-se maior com a extensão prolongada do período de retenção do ativo e menor com a consideração de incertezas específicas ao ativo (como a falta de mercados secundários organizados). Os juros impactariam em maior grau os bens de capital mais duráveis e que possuem mercados secundários mais definidos, tendo menos influência naqueles capitais com características opostas.

As quase-rendas obtidas podem ser mantidas dependendo do grau de disseminação do capital. Cabe notar que a noção de investimento em bens de capital em Keynes leva em conta a escassez relativa desses bens e certo entendimento sobre a ampliação da base produtiva da economia. A eficiência marginal do capital declina com a acumulação de capital, pela circunstância de que os retornos do capital decorrem de sua

89 Para Shackle (1970, p. 75-76), as suposições sobre os rendimentos relacionam-se a construções intelectuais fundamentadas, mas não garantidas, na realidade: "the firm must try to form some conception of the possible net revenue from such a piece of equipment far into future years, and in deciding whether or not to buy that equipment, it must remember that its suppositions about their net revenues are, in essence, figments and not facts. They are not fictions in the sense of mental creations unrelated to contemporary evidence concerning the perceived world. But they are intellectual constructs only founded on, and not guaranteed by, such evidence. They are highly, and irredeemably, uncertain".

${ }_{90}^{90}$ Também os ativos usados como garantia podem ser afetados, em razão de reavaliações, uma vez que um aumento nas taxas de juros reduz o valor dos ativos usados como colateral. A oferta de empréstimos pode ser diminuída se o tomador não tiver ativos adicionais. 
escassez. Quanto mais disseminado for o capital, menores serão seus retornos. Chick (1983) explica que, à medida que a acumulação ocorre, é verificada elevação do preço de oferta dos bens de capital. Minsky (1986, p. 200) nota que o investimento é empreendido "to alleviate a shortage of particular types of capital as made manifest by profits earned and anticipated. The level and the composition of demand determine the profits that capital assets earn, and capital assets are valuable only because they earn profits."

Para Keynes a ideia de que um capital é produtivo advém da obtenção de rendimento ao longo do ciclo de vida acima do preço de oferta, o que ocorre por meio da escassez relativa do capital. A relação da escolha de ativos será determinante para essa escassez. Com o aumento da acumulação, embora as propriedades técnicas do capital não reduzam a produtividade física, passa a haver redução no rendimento em excesso. Nas palavras do autor (1936, p. 213):

the only reason why an asset offers a prospect of yielding during its life services having an aggregate value greater than its initial supply price is because it is scarce; and it is kept scarce because of the competition of the rate of interest on money. If capital becomes less scarce, the excess yield will diminish, without its having become less productive at least in the physical sense.

A oposição que se pode formar entre investimento em bens de capital e aplicações financeiras está presente no mecanismo de preços relativos do modelo de escolha de ativos e pode ser objeto de políticas públicas. A taxa de juros própria da moeda desempenha papel essencial no estímulo ou restrição ao investimento, como destaca Amado (2000).

Além da possibilidade de manter taxa de juros em nível condizente com o pleno emprego, Keynes, no capítulo 24 da Teoria Geral, via espaço para disseminação do capital na economia, para aproximação com o nível de pleno emprego. Foi defendida certa socialização do investimento, com maior participação dos investimentos públicos para mitigar a possibilidade de demanda efetiva insuficiente, sem excluir a cooperação público-privada. Assim, a expansão do investimento deve implicar a diminuição da escassez dos bens de capital e das rendas obtidas com essa escassez ${ }^{91}$.

\footnotetext{
${ }^{91} \mathrm{O}$ fim da escassez geraria, na expressão de Keynes, a eutanásia do rentista, consolidando "the euthanasia of the cumulative oppressive power of the capitalist to exploit the scarcity-value of capital". O autor nota que "there are no intrinsic reasons for the scarcity of capital", uma vez que os juros não remuneram qualquer sacrifício ou abstinência. O fim do rentista, o "functionless investor", aconteceria de modo gradual com o aumento do investimento, sem necessidade de revolução.
} 
A perspectiva de Keynes e dos pós-keynesianos fornece elementos teóricos para entender a firma e o investimento nas economias monetárias de produção. A firma, independentemente do porte ou da estrutura de mercado, existe para acumular riqueza em forma monetária e está associada a capacidades, recursos e decisões frente à concorrência e à incerteza. A decisão de investimento, notadamente em ativos fixos e bens de capital no caso da firma produtiva, torna-se crucial e estratégica na economia e se encontra amalgamada a diversas escolhas relacionadas a preços e concorrência.

\subsection{Firma, investimento e análise setorial no capitalismo}

Nesta seção, são avaliadas contribuições de Marx e Keynes que podem notadas de acordo com os assuntos discutidos anteriormente no capítulo quanto à concepção de firma e do investimento e do papel da indústria e da distribuição setorial na economia. As características próprias das firmas no sistema capitalista ou economia monetária de

produção podem ser observadas nas capacidades que cada firma desenvolve. O processo de trabalho e a estratégia frente à incerteza podem ser destacados. O investimento em bens de capital ou ativos fixos é muito relevante para os dois autores. Alguns conceitos podem ser utilizados para entender a importância da indústria e da distribuição setorial na economia, de maneira que Keynes e pós-keynesianos e Marx permitam contribuir com o estudo do papel diferenciado da geração de valor na economia e seu efeito setorial sobre o crescimento.

\subsubsection{Firma}

A concepção sobre a natureza das firmas no capitalismo pode apresentar complexidade quanto às capacidades e estratégias desses agentes nas economias capitalistas ou monetárias de produção. A noção de capacidades características apontadas pela teoria neoclássica na versão dos custos de transação apresentam limitações. Marx e Keynes fornecem elementos teóricos para reformular a lógica da importância analítica das firmas. O processo de trabalho capitalista, em especial no caso da firma produtiva, torna clara a prevalência da cooperação, do controle e da divisão do trabalho para a 
existência da firma. A incerteza fundamental em Keynes e a ação estratégica formam a base também para a presença da firma na economia.

A busca pelo lucro e a acumulação são centrais para Marx e para os póskeynesianos. A firma para Marx e para pós-keynesianos, como notado por Shapiro (2011), tem como objetivo comum essa busca. O motivo do lucro também vai além do mercado, pois se torna a norma da produção e se institucionaliza na firma ${ }^{92}$. A autora pondera que os mercados podem coordenar as operações da produção, mas não pensar sobre elas e as conexões e dificuldades na sua organização. O desenho dessa atividade é função da gerência, que é realizada dentro das firmas por pessoal especializado. São desenvolvidos conhecimentos próprios à firma na coordenação da produção e do trabalho.

Nesse sentido, o processo de trabalho e as vantagens organizacionais são determinantes. As firmas unem o conhecimento de muitos, ao combinar, por meio de sua organização, o trabalho realizado. Dessa forma, o trabalhador coletivo definido por Marx permite a criação de novo poder produtivo. O que pode ser empreendido dentro das firmas é, quantitativa e qualitativamente, mais do que é realizado pelos indivíduos trabalhando isolados. Por esse motivo as firmas aparecem nos mercados e se tornam a forma dominante na produção capitalista. De maneira semelhante, a vantagem organizacional da firma, em especial a grande corporação (megacorp), é importante para autores póskeynesianos, como Eichner (1976), com relação ao crescimento econômico e à acumulação de capital, sendo a eficiência dinâmica do investimento e da inovação mais importante do que a eficiência alocativa.

A visão da firma baseada em recursos ou competências parece mais adequada às noções evidenciadas por Marx e Keynes ${ }^{93}$, em contraste com a visão contratual dos custos de transação. Autores como Hodgson (1998, p. 25) definem a firma baseada em competências ou capacidades ${ }^{94}$ como:

\footnotetext{
92 Nas palavras de Shapiro (2011, p. 17), "The profit incentive of markets requires more than markets. Profit has to be legitimated for individuals to devote themselves to its pursuit, and production geared to its requirements. Profit has to become the norm of production, the measure of its efficiency and value, and this is not possible without the institutionalisation of profit in the for-profit firm".

${ }^{93}$ Em especial quanto à capacidade de geração de lucros.

${ }^{94}$ Para Hodgson (1998) pode ser identificado grupo de teorias da firma denominadas diversamente como “capabilities", "resource-based", or "competence-based". A perspectiva da firma evolucinária, baseada na metáfora da seleção natural no contexto da concorrência, conformaria um subconjunto desse grupo. Coriat e Weinstein (2010) enfatizam a noção evolucinária da firma e de suas rotinas, caracterizando-a como nexo de competências. A noção de firma evolucionária, em que se destacam as rotinas organizacionais, os mecanismos de busca e aprendizado e o ambiente de seleção e competição, tem como referência o trabalho de Nelson e Winter (1982). Na perspectiva evolucionária, as capacidades devem ser consideradas também quanto ao aspecto dinâmico, como Katkalo et al. (2010).
} 
The competence-based perspective sees the existence, structure and boundaries of the firm as explained in some way by the associated existence of individual or team competences - such as skills and tacit knowledge - which are in some way fostered and maintained by that organization.

Enquanto Coase considera as competências gerenciais como potencialmente contratáveis, Hodgson (ibid., p. 39) afirma que o que está associado com "managerial and entrepreneurial skills is not mere information or knowledge but sophisticated but essentially idiosyncratic judgements and conjectures in the context of uncertainty".

Nessa noção de competências, entendem-se como cruciais a divisão e o gerenciamento do trabalho para as capacidades e as razões para existência das firmas, presentes em diversas tradições, ressalta Hodgson (ibid.). Marx e Smith ${ }^{95}$ enfatizaram os processos dinâmicos de produção e divisão do trabalho, que foram negligenciados pela teoria marginalista, preocupada com curvas de custos e receita. Essa perspectiva encontra-se igualmente presente em autores como Knight e Penrose, mas também é significativamente próxima à abordagem de Keynes. Para Penrose, a consideração do processo de desenvolvimento interno de conhecimento tácito e outras capacidades é fundamental no crescimento da firma.

A caracterização das firmas mostrada por Marx e pós-keynesianos é própria do sistema capitalista ou economia monetária de produção. Conforme se nota nas contribuições associadas a esses autores, o caráter histórico e concreto desse agente econômico distancia-se da perspectiva neoclássica, calcada na universalidade dos custos de transação na explicação para o surgimento da firma ${ }^{96}$. A firma descrita por Marx aparece e evolui com base na relação social específica do capital como lócus do processo de trabalho e acumulação no capitalismo. Na visão presente em Keynes e desenvolvida pelos pós-keynesianos, a firma como centro de decisão estratégica apenas é concebida dentro do âmbito da incerteza do mundo não ergódico das economias monetárias.

\footnotetext{
${ }^{95}$ Conforme discutido anteriormente, a perspectiva de Smith sobre a divisão do trabalho distingue-se da de Marx, para quem há diferença essencial entre divisão do trabalho interna e social.

${ }^{96}$ Malgrado as semelhanças apontadas, cabe notar que Marx e Keynes partem de noções diferenciadas de valor que influenciam a determinações fundamentais para a produção e o emprego. Marx, ao definir o trabalho socialmente necessário, relaciona entende o trabalho como fonte da riqueza. Keynes não abandona o primeiro postulado da economia (neo)clássica e mantém em seu arcabouço teórico a noção de produto marginal e a geração de riqueza pela contribuição de diferentes fatores produtivos. Já autores póskeynesianos descartam essa noção marginalista, sem, contudo, utilizar necessariamente a teoria do valor trabalho nas bases defendidas por Marx.
} 
Também as firmas moldam o mercado em que se inserem, principalmente as grandes firmas. O princípio da estratégia dominante ressaltado por Carvalho (1992) e discutido anteriormente constitui particularidade essencial da operação das economias capitalistas. Galbraith (1967), por exemplo, destaca a grande empresa que gasta recursos em publicidade para manipular o consumidor e desenvolver mercado próprio. É possível depreender de Marx que as firmas são importantes agentes da economia na relação de capital, ao ditarem a produção, o investimento e o mercado de trabalho (do lado da demanda e da oferta de mão de obra), impulsionadas pela lei do valor.

Ainda que algumas propostas de teorização da firma pós-keynesiana admitam caráter contratual ao surgimento desse agente, como Dunn (2002), a incerteza em um mundo não ergódico mesmo assim é reafirmada como mais um elemento de justificativa para a existência da firma. Configura-se como instituição que surge para diminuir a incerteza fundamental no mundo econômico, considerando aspectos mais complexos, para além do oportunismo dos agentes. As decisões estratégicas de investimento e sua relação com a produção e o financiamento são mais relevantes do que a eventualidade de serem quebrados contratos entre os agentes.

Apesar de reconhecer os contratos e as transações entre produtores livres na aparência do capitalismo, Marx situa as características essenciais do capitalismo na extração de mais-valor nas firmas produtivas, o que só ocorre a partir da subsunção real dos trabalhadores e opera de maneira coercitiva sobre os trabalhadores, que não detêm os meios de produção. Em razão do desenvolvimento histórico do processo de trabalho no capitalismo, antes de pensar em custos de transação, tem-se interesse na organização e controle do trabalho para o processo de valorização. O capital variável avançado pelos capitalistas é contratado por meio de mercado de trabalho capitalista, no entanto, apenas na aparência são os trabalhadores livres ofertantes de serviços produtivos. Caso não fossem empregados pelo capital, não teriam o que ofertar, estariam no exército industrial de reserva e não teriam outra forma, pelo mercado livre, de participar de qualquer processo produtivo.

Com efeito, as noções de processo de trabalho, acumulação e concorrência podem auxiliar na compreensão de explicações mais profundas sobre a atuação da firma na esfera produtiva e industrial, enquanto a ênfase sobre a organização estratégica da firma e as estruturas de mercado enseja entendimento sobre atualidade e a complexidade da dinâmica empresarial. Também esses aspectos são influentes na atuação transnacional das firmas, como destacam Hymer (1976) e Cowling e Sudgen (1987). 
Ainda que as capacidades das firmas no sistema capitalista sejam centrais para o crescimento e a acumulação produtiva, diversos autores chamam a atenção para comportamento financeiro das empresas ou a financeirização no capitalismo contemporâneo (ver Mollo, 2015). A financeirização pode ser definida com o crescente papel de motivos, mercados, instituições e atores financeiros operando nas economias, com predomínio das operações e transações financeiras sobre as produtivas, destaca Epstein (2005).

Autores como Chesnais (2010) observam regime dominado pelas finanças, em que o capital portador de juros está no centro das relações econômicas e sociais. A mundialização financeira, junto com desregulamentação e liberalização, foi essencial para o desenvolvimento desse capital. Esse fenômeno está associado à formação de massa elevada de capital fictício que implica vulnerabilidade sistêmica da economia mundial. Nesse regime, há preocupações de mais curto prazo e acumulação financeira pelas firmas, em especial as transnacionais. Nesse contexto, Lazonick e O'Sullivan (1996, 2000) ${ }^{97}$ verificam contraste da perspectiva de crescimento de longo prazo, conhecida como "retain and invest", presente nas empresas até a década de 1970 nas economias mais ricas, com, a partir do decênio seguinte, a mudança na governança corporativa em direção ao "maximize shareholder value" e "downsize and distribute".

Segundo Crotty (2005), o período recente do capitalismo foi caracterizado pelo "paradoxo neoliberal”, segundo o qual as corporações não financeiras, para se manterem na concorrência, baixavam salários, com isso baixavam demanda, incorriam em fraudes para mostrar lucros e trocavam seus lucros operacionais por ganhos nos mercados financeiros. A financeirização foi acompanhada de aumento da competição capitalista em mercados oligopolizados mais centrais à produção mundial, bem como fusões e aquisições. Embora as firmas não-financeiras tenham observado lucro e fluxo de caixa menores, a contração de dívida, o pagamento de dividendos (a partir da década de 1980), e as recompras de ações dessas empresas, em meio a incentivos direcionados à maximização do valor do acionista, contribuíram para a piora do desempenho econômico e para a propensão às crises. Os efeitos da financeirização podem ser sentidos também na capacidade inovadora das firmas, nota Mazzucato (2013), as quais, em determinados

\footnotetext{
${ }^{97}$ Lazonick e O'Sullivan $(1996,2000)$ questionam a sustentabilidade da prosperidade econômica de acordo com essa tendência, de transformação da estratégia corporativa nos EUA de retenção de lucros e reinvestimento para outra de downsizing da força de trabalho e a distribuição de lucros aos acionistas.
} 
setores como farmacêutico e energias renováveis, podem, de acordo com algumas evidências empíricas, estar diminuindo pesquisa em favor de recompras de ações.

A financeirização recente, nota Mollo (2015), está relacionada ao desenvolvimento do capital financeiro, que só pôde realizar-se por causa da liberalização dos mercados financeiros. O capital financeiro permite que coisas que não tenham valor apresentem um preço que se valoriza. A valorização foi associada ao curto prazo com especulação em títulos e pagamento de gerentes com opções de ações, junto com recompra de ações, no caso da firma, enquanto, de maneira geral, desenvolvia-se o comércio de moedas, de dívidas (securitização) e de dívidas de dívidas (derivativos). Essa valorização fictícia era concentrada em alguns mercados mais desenvolvidos. Mais recursos se deslocam da esfera produtiva para a financeira.

De todo modo, ainda que haja maior inclinação financeira, com efeitos sobre o crescimento e a instabilidade, as firmas produtivas ainda conservam base relacionada ao objetivo lucro na produção e nas capacidades, em especial a inovação. Lavoie (2014) encontra elementos fundamentais das firmas que remanescem no capitalismo.

O objetivo do lucro e do crescimento da firma ou da acumulação de capital, mesmo em forma financeira e com visão mais de curto prazo, é dominante para marxistas e pós-keynesianos, mesmo com as mudanças corporativas e de gestão associadas a menor regulação da atividade econômica. A grande firma contemporânea parece estar vinculada às transformações do sistema capitalista de maneira que se reforcem diversos elementos conceituais presentes nas concepções de Marx e Keynes sobre a complexidade da atuação desses agentes fundamentais na dinâmica econômica.

\subsubsection{Acumulação e investimento}

O motivo do lucro para as firmas está associado ao ambiente competitivo, tecnológico e financeiro para Marx e Keynes. Nas contribuições desses autores, alguns elementos teóricos são relevantes para a compreensão do sistema capitalista quanto à acumulação e ao investimento.

Existe uma diferença entre o direcionamento de recursos para a produção e o investimento e a especulação ou esfera financeira. Em Marx, a oposição pode dar-se entre o lucro e os juros. Em Keynes, a diferença entre especulação e empreendimento é relevante para o autor. Essa tensão, com a possibilidade de direcionamento de mais 
recursos para ativos financeiros que não adicionam capacidades produtivas na economia, parece significativa para o desempenho geral na economia.

A instabilidade no capitalismo está bastante associada ao investimento. São características fundamentais do investimento em bens de capital a falta de liquidez e a incerteza verdadeira associada a essa forma de investimento. Keynes atribui significativa ênfase a essa incerteza, que se vincula ao caráter incerto, ainda que objetivo, da determinação da eficiência marginal do capital para cada investimento em bens de capital novos. Em Marx, está implícita a noção da possibilidade de desvalorização do capital fixo e da perda de seu valor de uso em razão da capacidade de extrair mais-valia do trabalho no processo produtivo, pelo desenvolvimento tecnológico. A dificuldade de avaliar o valor dos investimentos pode adiar projetos e deslocar ações para formas mais líquidas de alocação de recursos.

A necessidade de levantar capital ou recursos monetários para financiar o investimento também não é simples para Marx e Keynes. Nos dois autores, a incerteza quanto a produção e investimento não torna irrelevante o papel da origem dos recursos para financiamento ${ }^{98}$. É essencial para Marx a noção de que os juros constituem dedução da mais-valia gerada e implicam relação de poder no capitalismo, sem que haja certeza sobre a realização dos lucros e obtenção de moeda suficiente para honrar compromissos. Em Keynes e nos pós-keynesianos, a fragilidade financeira se torna fundamental para entender o comportamento das firmas e dos agentes, além das oscilações na economia.

O caso da demanda por moeda para o investimento também se torna significativo nos dois autores. $\mathrm{O}$ entesouramento e os empréstimos são importantes para levantar recursos para o investimento, em que Marx verifica entesouramento recorrente a partir do volume de moeda gerado no ciclo do capital industrial. Para Keynes, o motivo financiamento para reter moeda, conforme discutiu em artigos posteriores à Teoria Geral, refere-se à demanda por moeda em antecipação despesas discricionárias planejadas, como o investimento das firmas ${ }^{99}$.

Uma interpretação da complementaridade das contribuições Marx e Keynes pode ser feita considerando-se formas distintas de comportamento das firmas frente à concorrência e incerteza com implicações distintas sobre o investimento e o trabalho na economia. Quando os mercados estão crescendo, pode haver acumulação de capital e aumento de emprego e salários.

\footnotetext{
${ }^{98}$ Diferentemente, pois, da previsão decorrente do teorema de Modigliani-Miller.

${ }^{99}$ Ver, por exemplo, Mollo (2003).
} 
Em regime com mais competição e lucros menores, como no período neoliberal, as firmas podem buscar estratégias de sobrevivência via projetos de investimento cortando empregos e salários e sem aumentar a capacidade produtiva, ao mesmo tempo em que se endividam e aumentam a fragilidade financeira, como formula Crotty (1993). Esse regime, que está associado à mudança tecnológica, traz menos crescimento e aumento no desemprego ${ }^{100}$. Nessa postura defensiva, a firma, voltada ao curto prazo, pode ter postura de maior alavancagem e grau de fragilidade financeira, para levantar recursos para a sobrevivência, e até mesmo reduzir gastos com P\&D em aumento de capacidade. Adicionalmente, podem ser buscados lucros na esfera financeira.

Nota-se que a concorrência e a operação livre da economia capitalista não estão associadas a mecanismo de alocação de recursos eficiente, em especial quanto ao nível de emprego e renda. Para Marx, a acumulação de capital é impelida pelo imperativo de obter mais lucro, o que, combinado com a atividade inovadora, tem efeito de liberação ou desemprego de mão de obra, bem como de disputa entre capital e trabalho pelo nível dos salários reais. Assim, conforme Mollo (2001), diferentemente da visão dominante em economia, segundo a qual a concorrência entre mercados e países é salutar, conduzindo a maior igualdade e maiores estabilidade e eficiência alocativa, a concepção marxista de concorrência leva à concentração e centralização do capital e ao desemprego estrutural ou tecnológico. A concorrência é responsável por maior desigualdade e pobreza entre países e no interior dos países e implica perdas para os trabalhadores.

Para Keynes, o mecanismo da concorrência não é neutro, uma vez que se deve analisar a eficiência dinâmica do ajustamento à luz de supostos mais realistas sobre a operação do mercado. Em The end of laissez-faire, Keynes (1926) apresenta contestação à teoria microeconômica da concorrência desregulada como meio central de coordenação econômica ${ }^{101}$. A avaliação a partir supostos irrealistas desconsidera os custos da disputa

\footnotetext{
${ }^{100}$ Pode ocorrer, assim, recomposição do exército industrial de reserva. Como salienta Crotty (1993), a acumulação pode ocorrer sem mudança significativa na composição técnica do capital, com o objetivo de aumentar a capacidade instalada em face de mercados crescentes e certa tecnologia de produção e determinado processo de trabalho. Essa concorrência não ameaça a firma, que aumenta os lucros. Esse aprofundamento de capital, no entanto, pode reduzir o exército industrial de reserva, gerar aumento de salários e minar as condições de manutenção desse modo de acumulação. Se houver esse aumento dos salários e, consequentemente, queda na taxa de exploração, desencadeia-se mudança na estratégia competitiva, em que as firmas passam a investir em plantas e equipamentos que incorporam progresso técnico poupador de mão de obra. Como há menos lucros para investir e cada unidade de capital requer menos trabalho, o exército industrial de reserva recompor-se-á, junto com a taxa de exploração. Esse modo de acumulação significa situação de investir ou morrer, por causa da necessidade de aumentar lucros e crescimento em relação aos concorrentes.

${ }^{101}$ Também em Keynes $(1925,1927)$ é contestada essa forma de coordenação.
} 
no laissez-faire, ao olhar apenas os benefícios ao término do processo, que pode implicar perda de postos de trabalho e diminuição do nível de atividade.

\subsubsection{Papel da indústria e distribuição setorial na economia}

A distribuição setorial na economia, embora não seja tratada diretamente por Marx ou Keynes, pode ser discutida com base nos conceitos formulados por ambos. Nesse caso, também se tornam relevantes as complementaridades entre as formulações. O estudo do investimento em determinados setores considerados mais importantes de um ponto de vista teórico deve fornece elementos para a análise de opções de política econômica.

A discussão sobre a firma realizada anteriormente é relevante para a agregação setorial ou por atividade econômica, ou ainda por produto, em uma economia. O comportamento microeconômico pode ser agregado em setores conforme o tipo de produção realizada e aspectos das relações intersetoriais. O investimento em uma economia envolve alguns produtos que estão relacionados a setores cuja importância é imprescindível para o crescimento. Dessa forma, a perspectivas com base nesses autores pode indicar certas características importantes para a composição setorial da economia.

\subsubsection{Contribuições keynesianas}

A determinação do nível de emprego e a volatilidade na economia dependem do investimento para Keynes. A acumulação de ativos fixos, como observado, é essencial para o crescimento. Como essa acumulação ocorre por meio de setores como a indústria de máquinas e equipamentos e a construção civil, a demanda por investimento não é neutra quanto ao setor.

Em particular, diversas contribuições keynesianas, fundamentadas nos trabalhos de Kaldor, associam o desenvolvimento da indústria de transformação ao desenvolvimento geral das economias capitalistas. A demanda por bens da indústria é mais importante do que outros setores. A geração de valor adicionado em um setor pode não ter o mesmo impacto na economia na comparação com outros, como na indução ou aceleração do crescimento.

Kaldor (1966), ao discutir o fraco desempenho econômico do Reino Unido, chamou atenção para a "premature maturity" dessa economia, que perdia fôlego antes da hora. O autor reconhece como referências Adam Smith e Allyn Young, os quais 
enfatizaram interação entre fatores estáticos e dinâmicos que causam retornos crescentes com um aumento na escala das atividades industriais. Segundo Kaldor (ibid., p. 106):

A greater division of labour is more productive, partly because it generates more skill and know-how; more expertise in turn yields more innovations and design improvements. We cannot isolate the influence of the economies of large-scale production due to indivisibilities of various kinds, and which are in principle reversible, from such changes in technology associated with a process of expansion which are not reversible. Learning is the product of experience - which means, as Arrow has shown, (...) that productivity tends to grow the faster, the faster output expands; it also means that the level of productivity is a function of cumulative output (from the beginning) rather than of the rate of production per unit of time.

A indústria, em especial a de transformação, revelara propriedades mais diretamente associadas a esse caráter cumulativo na produção e no aprendizado.

De maneira correspondente, as conhecidas leis de Kaldor vinculam-se a regularidades empíricas verificadas no desenvolvimento econômico. Primeiro, quanto maior a taxa de crescimento da manufatura, maior será a taxa de crescimento da economia. Segundo, a lei de Verdoorn estabelece que a taxa de crescimento da produtividade do trabalho na manufatura é endógena à taxa de crescimento da produção desse setor. A expansão da produtividade agregada é positivamente correlacionada com o crescimento da produção e do emprego na indústria e negativamente relacionada com o emprego fora da indústria de transformação. Tregenna (2009) ressalta que, como as externalidades associadas a essas características podem não estar refletivas nos preços relativos, torna-se possível a ocorrência de estrutura setorial subótima para o crescimento.

A configuração de economias de escala dinâmicas está entre as principais características da manufatura, propiciando os efeitos de learning-by-doing, inovação e ligações intersetoriais que tornam a expansão da produtividade endógena à evolução da indústria. No processo de desenvolvimento econômico, a migração de mão de obra para um setor de maior produtividade como a indústria engendra crescimento na produtividade como um todo. As ligações a montante e a jusante são mais significativas na indústria. $\mathrm{O}$ progresso técnico é difundido, de maneira cumulativa, pelas máquinas e equipamentos utilizados como insumos nos outros setores.

O papel do investimento, que é variável central do desenvolvimento para Keynes, tem relevo de acordo com a composição setorial da economia. Como foi comentado, é importante o investimento em bens de capital fixo. Em particular, esse investimento é constituído em parte pela produção de setores como máquinas e equipamentos. Esses bens 
de capital, cujo uso incorpora maior progresso técnico, são utilizados por outros setores e permitem a disseminação tecnológica na economia.

A discussão em torno da questão setorial reconhece que a produtividade é específica ao setor e não apenas às habilidades dos trabalhadores. Dessa forma, a alocação setorial e a composição dos investimentos tornam-se fundamentais para 0 desenvolvimento econômico. A falta de liquidez dos bens de capital, que estão associados a usos específicos, também torna complexa a destinação de recursos à aquisição desses bens em uma economia monetária.

\subsubsection{Contribuições marxistas}

As características do processo de trabalho, da cooperação e da maquinaria para Marx discutidas anteriormente revelam preocupação com a indústria no desenvolvimento capitalista. Marx (1885) desenvolve análise em termos setoriais, em setores de meios de produção e de consumo, nos esquemas de reprodução, observando divisão por categoria de uso. Algumas noções do autor, principalmente quanto ao papel da indústria no capitalismo estudado anteriormente, permitem entender o papel significativo da indústria e podem aproximar-se de contribuições conhecidas nessa área de estudos, como o estruturalismo.

A geração de mais-valor na economia pode ser chave para a distribuição setorial e o crescimento. Para Tregenna (2014), a perspectiva setorial do estruturalismo (seja keynesiano, como o inspirado em Kaldor, ou no estilo cepalino), que parte teoricamente dos setores econômicos como unidade de análise, pode ser enriquecida considerando-se a origem de geração de mais-valia setorialmente. Tregenna $(2013,2011)$ discute como a classificação setorial pode ser feita a partir da noção de formação de mais-valia na economia e, dessa maneira, do exercício do trabalho produtivo, segundo a concepção de Marx.

A análise de Marx não se dá geralmente no nível setorial, mas existem elementos para entender também esse aspecto. Como discutido anteriormente, entre as características importantes da indústria para Marx estão a divisão do trabalho, a socialização do trabalho, a mecanização, os retornos crescentes de escala, o aprendizado (learning-by-doing) e o potencial superior para expansão cumulativa na produtividade. Para Tregenna (2013), a especificidade das atividades para o crescimento a partir das contribuições de Marx pode ser classificada em duas dimensões, uma setorial e outra 
tecnológica-organizacional que (inclui escala, divisão do trabalho, uso de maquinaria e tecnologia, entre outras). Embora possam existir atividades fora da indústria de transformação que apresentem elevado grau de avanço tecnológico-organizacional, as características da indústria de transformação tendem gerar maior associação entre o setor e o progresso tecnológico-organizacional. Muitas das ideias sobre as características especiais da indústria e da causação cumulativa, desenvolvidas na literatura kaldoriana, podem ser encontradas em Marx ${ }^{102}$, como a lógica dialética da relação entre mecanização, divisão do trabalho, acumulação e desenvolvimento capitalista.

A cooperação ou socialização do trabalho e a divisão do trabalho são centrais para os retornos crescentes de escala, conforme comentado anteriormente. Tregenna (2013) enfatiza os animal spirits descritos por Marx, que constituem canal pelo qual a escala crescente de produção e a cooperação podem aumentar a produtividade do trabalho, além de outros associados à jornada coletiva. A divisão do trabalho torna-se essencial para a especialização, a qual, por sua vez, incrementa a produtividade e a extração de mais-valia. Há sinergia entre divisão do trabalho, especialização e socialização do trabalho na indústria. A noção de causação cumulativa pode ser encontrada em Marx, argumenta Tregenna, e ocasiona a possibilidade de histerese. Assim, uma economia em trajetória de mecanização, progresso técnico, crescimento na manufatura e altas taxas de acumulação e crescimento tende a seguir este caminho, ou, de maneira oposta, a ficar presa ao subdesenvolvimento. A concepção do learning-by-doing, como visto anteriormente, está implícita no pensamento de Marx, em especial quanto ao aprendizado nos trabalhos parciais.

Também a mecanização tem papel fundamental na concorrência e no desenvolvimento. A competição acelera a divisão do trabalho e a aplicação da maquinaria. A indústria de transformação, que é a base da mecanização, tem papel central. O progresso tecnológico é incorporado em novos bens de capital, implicando que a indústria de transformação sobressai no avanço tecnológico. Nesse contexto, a importação de bens de capital pode diminuir os benefícios associados à difusão e ao desenvolvimento de tecnologia.

\footnotetext{
102 Tregenna (2013) menciona que Marx "builds on Smith's exposition of the progressive role of the division of labour". No entanto, deve-se lembrar a crítica de Marx à análise restrita da divisão do trabalho da economia política de sua época, a qual apenas destaca a geração de valores de uso e a diferenciação de produtos, sem levar em conta a criação de valor no processo de trabalho. Também deve ser lembrada a crítica à especialização (ver Tauile, 2001, e Braverman, 1974), que, como foi apresentado anteriormente, não é a principal característica vinculada à divisão do trabalho e permite delimitar os conceitos na concepção de Marx.
} 
A industrialização tem papel central para Marx, mas apresenta relações complexas. Tregenna (2013) identifica em Marx caráter progressista da indústria de transformação, assim como papel histórico da grande indústria no desvelamento das contradições do capitalismo. Já com relação ao papel no desenvolvimento das forças produtivas e na consolidação do capitalismo, é correto entender que a indústria representa elemento histórico essencial, no entanto, os aspectos mencionados de alienação desqualificação do trabalho devem suscitar avaliação crítica dessa forma de produção social segundo a abordagem e a discussão feita por Marx.

Também a desindustrialização pode ser pesquisada com outro enfoque. Tregenna (2014) empreende classificação setorial com base nos conceitos de Marx com o intuito de avaliar a desindustrialização sob outro prisma. Os setores, de acordo com a abordagem de Marx, podem ser definidos de acordo com a geração de mais-valor, o que está associado à realização de trabalho produtivo ou improdutivo, e podem ser enquadrados nos três setores presentes nas contas nacionais, agricultura, indústria e serviços. Uma vez que o trabalho improdutivo está presente em todas as atividades, a principal classificação refere-se aos setores geradores de mais-valor.

As atividades que geram mais-valor e apresentam trabalho produtivo compreendem, segundo a autora, a produção da indústria de transformação, da indústria extrativa, da agricultura, de serviços mercantis e de transporte e armazenamento. Os ramos que geram mais-valor abarcam atividades capitalistas, enquanto as atividades não produtoras de mais-valor podem ser capitalistas ou não capitalistas. Entre as não produtoras de mais-valor, apenas os serviços relacionados à circulação, como os financeiros, são capitalistas, ao passo que existem atividades não capitalistas nos setores de transformação, agricultura e extrativo e de serviços.

Com relação aos serviços, Tregenna (2009) evidencia que Marx se mostra contrário à noção física de trabalho produtivo, compartilhada pela economia clássica, segundo a qual apenas bens materiais seriam resultado dessa forma de trabalho. Marx (1864) acreditava serem as atividades de serviços menos relevantes em comparação à produção de bens, à época em que escrevia. Os serviços na economia capitalista apresentam grande heterogeneidade quanto ao valor e ao trabalho, não devendo ser tratados de maneira unitária. Os serviços produtores de mercadorias estão associados ao trabalho produtivo e à geração de mais-valor. Cabe notar que atividades ou profissões iguais de serviços podem ser enquadradas de maneira diferenciada, como o jardineiro ou o professor, dependendo de serem realizadas de maneira produtiva, no processo de 
autovalorização do capital, ou de serem trocadas por renda (ou ainda nem serem realizadas de maneira capitalista). Já serviços circulatórios, que não transformam produtos nem adicionam valor ${ }^{103}$, representam custos de circulação financiados pelo mais-valor gerado em outras atividades, embora constituam forma de trabalho improdutivo que pode facilitar a realização do capital industrial ou aumentar a velocidade da circulação desse capital. Marx distingue, entre os custos de circulação, as atividades produtivas de transporte e armazenamento, as quais têm trabalho produtivo por, respectivamente, gerarem valor ou o preservarem.

Apesar da contribuição relevante, a classificação de Tregenna (2014) não considera, pelo menos expressamente, o setor da construção civil ${ }^{104}$, que compõe a indústria nas contas nacionais. Essa ausência pode ser significativa para a consideração do investimento na economia, em particular pelo papel fundamental desempenhado pela construção, mas também pelo destaque do capital fixo para a infraestrutura econômica e o desenvolvimento dos meios de produção. No caso do investimento, lembrando o modelo de Marx no Livro II de O Capital (1885), observa-se que a construção civil está presente no departamento produtor de meios de produção, junto com a produção de máquinas e equipamentos.

\subsection{Comentários finais}

Alguns fundamentos da firma e do investimento em Marx e Keynes são importantes para construir interpretação alternativa à visão dominante. O objetivo do lucro e a necessidade de acumulação ou investimento são características precípuas das firmas, que são constituídas por competências específicas para esse objetivo em meio a uma realidade não ergódica e à concorrência no processo de acumulação. Uma dinâmica setorial associada intrinsecamente à indústria quanto ao crescimento e o investimento pode ser verificada em Marx e Keynes.

\footnotetext{
${ }^{103}$ Tregenna (2009) comenta que os serviços circulatórios parecem transformar as mercadorias ou seu valor de uso, conquanto, na verdade, apenas mudem a propriedade dessas mercadorias. As atividades de serviços na esfera da circulação (como seria o caso de marketing) podem aumentar o preço de determinada mercadoria acima de seu valor subjacente, simulando a criação de valor, mas sem gerá-lo.

104 Também os serviços industriais de utilidade pública, relativos à infraestrutura (energia elétrica, água, etc.), não estão considerados explicitamente.
} 
Podem ser complementares para o entendimento de aspectos do comportamento das firmas e do investimento e das perspectivas setoriais na economia as abordagens de Marx e Keynes e contribuições posteriores com base nos dois autores. Enquanto os animal spirits dos trabalhadores são despertados pela cooperação que se torna mais ampla na indústria, explica Marx, os animal spirits dos empresários são imprescindíveis para a tomada de ação quanto ao investimento na economia, evidencia Keynes. Essas considerações permitem compreender como são relevantes para o desenvolvimento econômico políticas para incentivar essas características fundamentais que fornecem base para o crescimento.

A ação estratégica das firmas e o papel do investimento são importantes para Marx e Keynes. Em Marx, a depreciação moral do capital pode ser decisiva para desvalorizar o capital fixo frente a outros mais avançados tecnologicamente e, dessa forma, pode tornar-se elemento de incerteza excessiva na decisão dos capitalistas para ampliar produção e diminuir custos. Também a necessidade, para Keynes, de abrir mão do dinheiro, a dificuldade e a volatilidade na previsão da eficiência marginal do capital de cada projeto de investimento e a consideração da liquidez nas escolhas de alocação da riqueza são elementos fundamentais na decisão de investimento. Desse modo, o investimento em bens de capital tem caráter complexo no nível da firma, ao estar associado à incerteza sobre o valor ou o rendimento futuro desses bens, bem como ao caráter geralmente ilíquido dos bens de capital.

Os elementos teóricos definidos por Marx e Keynes das economias capitalistas destacam a importância do objetivo do lucro, da complexidade e da instabilidade. A noção de concorrência fundamental prevista por Marx pode auxiliar a perspectiva póskeynesiana quanto ao papel da dinâmica na análise econômica. A ênfase dos póskeynesianos no grau de monopólio e nas estruturas de mercados oligopolistas também se torna fundamental para o capitalismo contemporâneo. A concorrência e o capitalismo de laissez-faire podem ser criticados e podem suscitar intervenções estatais para diminuir os custos associados à dinâmica capitalista, embora as limitações da atuação governamental sejam importantes também no capitalismo.

As perspectivas avançadas por Marx e Keynes são úteis ao entendimento das limitações ao desenvolvimento econômico no capitalismo e para avaliar a pertinência de políticas econômicas conducentes ao crescimento ou que mitiguem os efeitos da instabilidade e da desigualdade inerentes ao sistema. 
Tanto para Marx quanto para Keynes a interação entre produção e o sistema financeiro são fundamentais para a economia capitalista. $\mathrm{O}$ sistema financeiro não é mero alocar de recursos excedentes, mas pode atuar, de acordo com o comportamento dos bancos, para reunir maiores somas de recursos para o processo de acumulação de capital, auxiliando a concentração e centralização dos capitais, ou para elevar a produção e o investimento, por meio da facilitação do financiamento.

A indústria de transformação pode ser vista como importante em perspectivas originadas nos dois autores. A indústria apresenta características relacionadas com o aprendizado e a disseminação do progresso técnico que a tornam importante para o crescimento de toda a economia, como se nota na tradição kaldoriana, mas também em Marx, para quem a geração de valor pode ter aspectos setoriais significativos.

Os diversos aspectos teóricos mencionados podem servir de base teórica para o estudo do desenvolvimento produtivo. A análise da economia capitalista realizada por Marx e Keynes é relevante para auxiliar na compreensão da realidade complexa das firmas, do investimento ou acumulação de capital e da dinâmica setorial.

A fundamentação macroeconômica associada a Marx e a Keynes define limites à atuação dos agentes. Os elementos teóricos avaliados no presente capítulo constituem base para entender outros aspectos da realidade econômica. $\mathrm{O}$ debate atual sobre políticas industriais ou de diversificação produtiva pode beneficiar-se de formulações teóricas presentes em Marx e Keynes, em combinação com diversas perspectivas heterodoxas. 


\section{Capítulo 3. Perspectivas sobre políticas de desenvolvimento produtivo e desenvolvimentismo}

\subsection{Introdução}

Neste capítulo, são discutidas questões importantes do desenvolvimento e das políticas industriais em diversas perspectivas, da ortodoxia à heterodoxia. Com especial interesse nas possibilidades de atuação estatal, outras formulações teóricas e históricas heterodoxas fornecem elementos mais concretos para a análise de aspectos presentes nas economias menos desenvolvidas, no que diz respeito à superação dos desafios associados ao processo de desenvolvimento econômico e social, e, desse modo, são importantes para a discussão do desenvolvimento brasileiro.

Podem ser verificadas diversas abordagens sobre políticas de desenvolvimento produtivo ou industriais. Embora tenha havido interesse recente por parte da ortodoxia no estudo da diversificação produtiva e da recomendação de políticas industriais, podem ser notadas algumas limitações quanto a aspectos teóricos e práticos nessa visão. Já as correntes heterodoxas têm tradicionalmente apresentado discussão sobre a necessidade de mudança estrutural para o desenvolvimento por meio de outros pressupostos e políticas mais abrangentes.

As contribuições teóricas associadas ao contexto da periferia do capitalismo merecem destaque. Aspectos do debate sobre desenvolvimento no Brasil e na América Latina na perspectiva estruturalista são fundamentais para entender diferentes escolas e perspectivas sobre esse processo em economias menos desenvolvidas ou periféricas. Os problemas associados ao posicionamento da periferia na divisão internacional do trabalho e à formação das economias nacionais são importantes para a estrutura econômica e as políticas para a superação do subdesenvolvimento. É relevante a preocupação com a estrutura subjacente a essas economias.

Já as perspectivas quanto à política industrial e à diversificação produtiva têm importância decisiva nas perspectivas heterodoxas, estruturalistas e desenvolvimentistas, em que se destaca o papel do Estado para superar entraves e fomentar atividades e inovações que não seriam desenvolvidas naturalmente pelo mercado. $\mathrm{O}$ debate brasileiro está associado à discussão estruturalista e desenvolvimentista, para a qual podem ser 
trazidas algumas dimensões teóricas discutidas com base em Marx e Keynes. As noções associadas à contribuição teórica desses últimos autores, ainda que em diferentes concepções, podem auxiliar no debate brasileiro e no destaque ao desenvolvimentismo social.

Além dessa introdução, o capítulo está organizado em mais cinco seções. São apresentados elementos da discussão na ortodoxia sobre diversificação produtiva na seção 3.2. Na seção 3.3, aspectos do estruturalismo latino-americano e de política industrial na visão desses autores são apresentados. A seção 3.4 utiliza elementos teóricos de Marx e Keynes para discutir a atuação do Estado e políticas industriais. A seção 3.5 trata do debate desenvolvimentista sobre desenvolvimento produtivo e política industrial no Brasil, incluindo considerações sobre os autores pesquisados. Em seguida, são apresentados comentários finais.

\subsection{Políticas industriais e diversificação produtiva na ortodoxia}

O debate recente sobre política industrial, mesmo no campo ortodoxo, parece ressurgir e convergir para a necessidade de buscar políticas de diversificação da atividade produtiva e de desenvolvimento da capacidade inovadora. No entanto, há limitações sobre a escolha das atividades a serem incentivadas e sobre os instrumentos a serem usados, de acordo com posições teóricas inerentes à visão mainstream. A fundamentação teórica está associada a políticas que impliquem, em geral, a diminuição de falhas de mercado, como informação imperfeita e externalidades. A escolha setorial pode ser conduzida de maneira diferenciada e seguir os mecanismos de mercado ou condições de oferta. A ação estatal, mesmo que se conceda essa possibilidade, não é vista sem receio, em virtude da possibilidade de falhas de governo.

O histórico recente de indicação de políticas tem mostrado certas mudanças nas recomendações com base em imperfeições de mercado. $\mathrm{O}$ fundamentalismo de mercado pode não ser justificado teoricamente mesmo pela economia neoclássica recente, além de fornecer orientações piores de política econômica. Stiglitz (2008) reconhece que, desde a década de 1970, a teoria econômica mostra que falhas de mercado, como externalidades, imperfeições na informação, bens públicos, limitações na concorrência e mercados 
incompletos, são pervasivas na economia e no processo de desenvolvimento e implicam, nessas situações, que os mercados não são eficientes. Greenwald e Stiglitz (1986), por exemplo, mostram como, na presença de diversas externalidades relativas a informação, adicionalmente a diversas outras conhecidas na literatura, existe a possibilidade de intervenção estatal no sentido de uma melhoria de Pareto, para restabelecer a eficiência da economia competitiva. Esses avanços na teoria econômica neoclássica teriam removido o apoio teórico ao fundamentalismo de mercado mesmo antes de o Consenso de Washington ser disseminado no mundo em desenvolvimento ${ }^{105}$.

Apesar dessas noções teóricas, a atividade estatal recente, voltada principalmente a diversas formas de liberalização e diminuição da participação governamental, desconsiderou aspectos relativos a incentivos em face de imperfeições e questões distributivas, que são importantes até mesmo para a eficiência, destaca Stiglitz (2008). Igualmente, essa aplicação parece ter sido determinante no desempenho diferenciado na economia mundial. Na América Latina, como resultado dessas políticas, a expansão do início dos anos 1990 foi seguida por anos de estagnação e recessão até o início da década de 2000, o que representou a metade do crescimento durante os anos de substituição de importações das décadas de 1950 a 1970 (que teriam sido ineficientes) ${ }^{106}$. Já os países do Leste da Ásia tiveram maior desenvolvimento e seguiram conjunto distinto de políticas exitosas ao promoverem atividades específicas, por meio da ação estatal, ao mesmo tempo em que a estabilidade macroeconômica foi seguida, houve demora na liberalização comercial e empresas estatais asiáticas se tornaram líderes globais.

Assim, autores como Stiglitz et al. (2013) têm reconhecido a necessidade de políticas industriais e o rejuvenescimento do pensamento sobre essa forma de atuação após a crise em 2008-2009. O argumento tradicional era de que os mercados seriam eficientes a ponto de não necessitarem de intervenção na alocação setorial de recursos ou na escolha de técnicas, assim como a intervenção não seria eficiente. Contemporaneamente, existiria novo ímpeto e aceitação, até mesmo por economistas mainstream, para essas políticas, as quais são praticadas em economias desenvolvidas, como EUA, Reino Unido e UE, e emergentes, como China, Rússia, Brasil, Índia e

\footnotetext{
105 Stiglitz (2008, p. 43) escreve que "there is no theoretical underpinning to believe that in early stages of development, markets by themselves will lead to efficient outcomes".

${ }^{106}$ Mesmo em países que aplicaram o Consenso de Washington e parecem ter obtido melhor desempenho no crescimento, não ocorreu redução significativa na pobreza.
} 
Indonésia ${ }^{107}$. Uma das principais questões seria incorporar a importância da aquisição do conhecimento ou aprendizagem, uma vez que os mercados falhavam ao maximizar essa aquisição ${ }^{108}$.

O conhecimento torna-se mais importante em alguns setores. Stiglitz e Greenwald (2014) defendem que os incentivos setoriais são justificados pelo ganho com conhecimento nos ramos mais promissores em termos de aprendizado, como a indústria. A avaliação da inovação implica a importância da história, em razão de que a tecnologia desenvolvida hoje é remunerada no futuro. Existem spillovers de conhecimento que serão imperfeitamente internalizados na economia de mercado. Presentes essas imperfeições e outras, os preços dos fatores, em especial nos países em desenvolvimento, vão diferir dos preços sombra (os verdadeiros custos sociais marginais), por causa de diversas falhas de mercado $^{109}$. Essa divergência gera perda de eficiência alocativa e pode ser corrigida pelo governo (por meio, por exemplo, de subsídios), com ganhos dinâmicos ${ }^{110}$. Nessa intervenção, existem custos ao governo e a possibilidade de distorção nos mercados (pela necessidade de instituir impostos), os quais, entretanto, podem ser compensados com a inovação e o bem-estar gerado. Os objetivos da política industrial estariam associados ao alinhamento dos incentivos do mercado aos objetivos públicos.

A possibilidade e as necessidades de política industrial podem ser bastante variadas na ortodoxia, sem que deixem de ser feitas críticas frequentes às falhas de governo e dessas políticas. Lin e Monga (2013) reiteram a presença de externalidades como a principal justificativa teórica para a instituição de políticas ativas, sejam setoriais ou horizontais. A teoria neoclássica admite a necessidade de intervenção governamental apenas em situações de falhas de mercado, situação em que os mecanismos de mercado não alocam recursos eficientemente ${ }^{111}$. É o caso de externalidades positivas, como P\&D

107 Stiglitz et al. (2013, p. 1) chegam a afirmar que "Today, the relevance and pertinence of industrial policies are acknowledged by mainstream economists and political leaders from all sides of the ideological spectrum."

${ }^{108}$ Os economistas do desenvolvimento, surpreendemente, teriam "typically not focused on this issue, nor on the implications for the desirability of government intervention", segundo Stiglitz et al. (2013).

${ }^{109}$ As proposições teóricas podem ser notadas por meio de ferramental próximo do presente na economia do setor público, com modelos de equilíbrio geral com consumidores idênticos, otimização e crescimento da produtividade diferenciado entre setores, mostram Stiglitz e Greenwald (2014). Se o governo conseguir induzir pequeno aumento no consumo do setor com maior aprendizado (em detrimento dos outros), haverá perda de bem-estar no presente, mas crescimento da curva de possibilidades de produção no futuro e maior bem-estar.

${ }^{110}$ A internalização desses custos pode ocorrer por meio, por exemplo, de monopólios. No entanto, a produção nesse mercado é mais baixa e requer intervenção governamental.

${ }^{111}$ Lin e Monga (2013) citam também, fora da escola neoclássica, abordagem evolucionária, que prevê a acumulação de capacidades de maneira sistêmica na economia. 
e aprendizado; de externalidades marshallianas, relativas a setores ou atividades, como economias de aglomeração; falhas de coordenação, em razão dos custos de transação e das características de bem público da infraestrutura física e intangível ${ }^{112}$ (instituições); e assimetrias de informação e mercados incompletos, que implicam seleção adversa e risco moral. Ainda assim, as falhas de política industrial são assinaladas e associadas com fraquezas das estratégias defendidas ideologicamente por estruturalistas antigos ${ }^{113}$. A obsessão com falhas de mercado teria levado a políticas setoriais voltadas para dentro. $\mathrm{Na}$ tentativa de buscar maior intensidade de capital, a literatura neoclássica atenta para políticas de investimento ineficientes e distorções de preços; existência de empresas públicas com monopólios; alto índice de captura e rent-seeking; e repressão financeira. Para Lin e Monga, particularmente, as políticas industriais muitas vezes falharam por conta da definição de objetivos inconsistentes com a estrutura de dotações, gerando firmas inviáveis frente à concorrência internacional, por causa da proteção e do desvio frente às vantagens comparativas das economias.

Nesse sentido, uma perspectiva influente na ortodoxia dirigida aos países em desenvolvimento é a da nova economia estrutural (new structural economics), como proposta por Lin $(2012)^{114}$. A diferença para a velha economia estrutural estaria no papel relevante do Estado na promoção da diversificação e do aprimoramento industrial como facilitador do setor privado ${ }^{115}$, nas áreas em que a economia tem vantagem comparativa corrente ou latente. Nesse caso, a estrutura industrial ótima que fará a economia mais competitiva interna e externamente em determinado momento é considerada endógena com relação às vantagens comparativas, que são definidas pela estrutura de dotações dadas na economia no determinado momento.

Para a economia crescer sem distorções, nessa perspectiva, é necessário sistema de preços relativos que reflita a escassez dos fatores de produção na estrutura de dotações. Esse sistema de preços relativos existe apenas em um sistema de mercado competitivo. Como falta esse sistema nos países em desenvolvimento, seria necessária ação

\footnotetext{
${ }^{112}$ Lin (2012) denomina as infraestruturas hard e soft.

${ }^{113}$ De acordo com Lin e Monga (2013), "Ideological motivations were reinforced by the early structuralist approach to economic development, which centered on the elimination of market failures and argued that industrialization and growth could not take place spontaneously in developing countries because of structural rigidities and coordination problems."

114 Essa maneira de adaptar prescrições de política industrial aos países menos desenvolvidos foi amplamente divulgada recentemente pelo Banco Mundial, do qual Lin foi economista-chefe.

115 São também destacados por Lin (2012) o fornecimento de informação sobre novas atividades, a coordenação dos investimentos entre firmas e setores, a internalização de externalidades relativas a informação e a preparação de novas atividades por meio do apoio a investimentos estrangeiros diretos
} 
governamental para melhorar as instituições de mercado e os mercados de fatores e produtos, principalmente pela informação suficiente para que os agentes compreendam a escassez e, portanto, os preços relativos ${ }^{116}$. A ação estatal que desafia as vantagens comparativas vai direcionar recursos excessivos para proteção e subsídios a firmas que não vão tornar-se competitivas internacionalmente de maneira rápida ${ }^{117}$. Assim, esses fluxos de recursos serão desviados de fatores de produção necessários para a estrutura produtiva avançada no médio prazo, ocasionando igualmente a distorção de sinais de mercado e encorajando as atividades rent-seeking ${ }^{118}$ ao invés do empreendedorismo produtivo.

A crítica excessiva às falhas de governo, cujas distorções seriam maiores do que a ineficiência da alocação de mercado e a divergência entre preços sombra e de mercado, pode ser considerada exagerada, pois não haveria nem razões teóricas nem evidências empíricas para sustentar essa opinião, advertem Greenwald e Stiglitz (2013) ${ }^{119}$.

De todo modo, na nova economia estrutural, a acumulação de capital provém da acumulação de dotações, cujos preços relativos devem ser descobertos. O modelo subjacente às vantagens comparativas é o Hecksher-Ohlin-Samuelson. Esse modelo está associado à eficiência alocativa e tem como hipótese a livre mobilidade de fatores e a mesma tecnologia de produção entre países. As políticas devem ser direcionadas para as vantagens comparativas dos países. Se os incentivos diferirem dessas vantagens, haverá também custos de transação derivados de infraestrutura insuficiente para aqueles fatores. A possibilidade de desvio das poupanças na economia, para gerar o investimento requerido, parece central nessa abordagem.

Anda que as falhas de mercado estejam na origem do pensamento ortodoxo sobre política industrial, cabe notar que as vantagens comparativas são questionáveis para diversos autores nessa tradição. Há discordâncias quanto a essa conformação às vantagens

\footnotetext{
116 Nas palavras de Lin e Monga (2013), “comparative advantage can be seen as the silver bullet for industrial policy".

${ }^{117}$ Para Lin, em Lin e Chang (2009), o protecionismo via tarifas de importação presente no argumento da indústria nascente também não seria adequado, por causa da possibilidade de incorporar custos relativos ao desenvolvimento tecnológico à análise, como realizado por Baldwin (1969).

118 A capacidade dos agentes políticos de realizar intervenções é limitada pelo comportamento autointeressado desses agentes, por um lado, ao mesmo tempo em que os governantes, por outro lado, estão sujeitos a captura por firmas ou grupos empresariais que revelam atitude rent-seeking, como destacado por Krueger (1974).

${ }^{119}$ Escrevem Greenwald e Stiglitz (2013) que "A persistent criticism of industrial policies is that, even if market allocations are inefficient, even if market prices differ from shadow prices, government attempts to correct these failures will simply make matters worse. There is neither theory nor evidence in support of this conclusion".
} 
comparativas dentro do campo neoclássico. Greenwald e Stiglitz (2013) reconhecem que é sabedoria convencional enfatizar que são mais importantes as vantagens comparativas dinâmicas e admitem mesmo que é difícil definir a vantagem comparativa de economias específicas, por falta de mobilidade do capital e conhecimento. Países como a Coreia do Sul teriam continuado pobres se tivessem seguido as vantagens comparativas estáticas em arroz na época em que começaram a produzir chips de computadores. A dotação que seria relevante é a capacidade de aprender da sociedade. Ainda assim, definir a vantagem comparativa dinâmica de determinada economia é árduo e envolve julgamentos estratégicos entre os países ${ }^{120}$. De todo modo, em razão dos custos de aprendizado e dos riscos de falhar, Greenwald e Stiglitz (ibid., p. 62) defendem avanços moderados ou graduais na tecnologia, em direção a produtos que não estão sendo feitos por outros.

O campo de estudos associado ao aprendizado e o descobrimento de custos tem sido significativo na literatura mainstream. A especialização das economias vincular-seia menos a vantagens comparativas e dotações de fatores do que às externalidades de coordenação e informação, de acordo com algumas pesquisas. Rodrik (2010) assinala que o que cada país produz importa para o desenvolvimento econômico. São importantes nesse sentido estudos como de Hausmann et al. (2007), de que a especialização em determinadas exportações está associada com o aumento do PIB per capita, e de Imbs e Warcziag (2003), que mostram tendência dos países a aumentarem a diversificação da produção junto com o crescimento do PIB per capita até nível depois do qual passam a especializar-se. Rodrik (2010) reconhece que países com a mesma dotação e vantagens comparativas têm padrões de especialização distintos, ao contrário do que previsto usualmente. Assim, nem todos os países em desenvolvimento concentram suas exportações em produtos intensivos em recursos naturais ou em mão de obra barata. Os países que também exportam alguns produtos próprios de países desenvolvidos tendem a crescer mais rapidamente, com aparente independência de seu capital humano e sua qualidade institucional. Esse fenômeno é idiossincrático e parece estar ligado às facilidades para empreender a produção e exportação de produtos novos.

Para Rodrik (2010), existe ampla margem para que as políticas exerçam uma influência determinante na criação da cesta de bens que um país produz e que facilita o

${ }^{120}$ Greenwald e Stiglitz (2013) concedem que "guidance about its comparative advantage defined in this way (dynamic learning capacities) is much more difficult, partially because it depends on judgments made by other countries about their dynamic comparative advantage and their willingness to invest resources to enhance those advantages". 
crescimento. Apesar de admitir a impossibilidade de receitas universais, o autor indica algumas características desejáveis das políticas industriais. Deve haver concessão de incentivos e subsídios somente a atividades novas, com o estabelecimento de pontos de referência e critérios claros de êxito e fracasso dos projetos subsidiados. Deve também existir a compreensão de que, no contexto de políticas industriais ótimas, às vezes são escolhidos projetos perdedores. É importante o apoio a atividades de fomento capazes de evoluir para que o ciclo de descobrimento seja constante.

Não obstante certo posicionamento dentro da economia tradicional que se consolidou na prescrição de políticas industriais ou de desenvolvimento produtivo, algumas limitações podem ser observadas. A possibilidade de políticas que incluem estímulos setoriais parece presente no pensamento ortodoxo recente em associação à identificação de falhas de mercado variadas. A consideração da base teórica de indivíduos otimizadores em face de externalidades mostra como a verificação empírica de desvios do mercado competitivo na perspectiva neoclássica é tratada como anomalia, ainda que muito comum, ubíqua e particularmente importante para os países em desenvolvimento.

Mesmo em análises que contêm elementos significativos de evolução e acumulação de conhecimento, como Stiglitz e Greenwald (2014), o referencial teórico é de que o aprendizado envolve externalidades frente a um mercado perfeito, que pode ser apreendido pelo governo. A intensidade da intervenção tem como base a avaliação da diferença entre os preços sombra e os preços de mercado. A narrativa está direcionada às imperfeições, contudo, parte-se de mercado perfeito na teoria para formular táticas que dependem de uma ou mais falhas de mercado, mesmo que sejam second-best ${ }^{121}$, para chegar-se a intervenção compensada na medida da distinção frente ao mercado perfeito. A noção de história e de ganhos dinâmicos na ortodoxia está associada à otimização intertemporal do crescimento dos fatores ou das possibilidades de produção e menos aos fatores institucionais e diferenças nas estruturas econômicas das economias.

Mais fundamentalmente, com base em perspectiva heterodoxa, as noções convencionais podem ser criticadas pelo caráter não determinístico da realidade em que as decisões de Estados e firmas são feitas. Na falta informações perfeitas sobre preços relativos e dotações, bem como o estado da natureza presente, não há fonte para a definição de vantagens comparativas para o governo ou os agentes. Também as rendas

${ }^{121}$ As falhas de mercado podem verificar-se simultaneamente, como a existência de poder de mercado e falhas na informação. Essa situação requer que o governo, ao corrigir uma, não exacerbe outras, como ressaltado por Stiglitz e Greenwald (2014). 
futuras do conhecimento e os custos de aprendizado no tempo, uma vez tomadas decisões, dependem de ambiente complexo em mutação constante. A realidade presente e futura teria de ser objeto de previsão. Não precisa haver suposição de indivíduos otimizadores independentes e atomizados.

Como discutido no capítulo 1, a articulação e o comportamento dos agentes são delimitados pelo ambiente social e macroeconômico, que tem influência da atuação estatal. Menos do tomar como dados os preços ou valores, existe evolução dinâmica nas economias capitalistas. As capacidades tecnológicas e produtivas, como visto no capítulo 2, estão relacionadas com a acumulação de capacidades no nível das firmas e de atividades ou setores, especialmente na indústria, em situação de incerteza e transformações na economia capitalista.

Chang, em Lin e Chang (2009), desconfia especificamente da noção de vantagem comparativa utilizada na perspectiva da nova economia estrutural. A acumulação de capacidades tecnológicas decorre de experiências concretas na produção, em forma de conhecimento coletivo incorporado em rotinas organizacionais e memórias institucionais. Embora as vantagens comparativas forneçam algum guia para avaliar o sacrifício da proteção, é muito difícil prever a duração e o custo das capacidades tecnológicas adequadas. A análise de custo-benefício tradicional sofre com os mesmos problemas da tomada de decisão empresarial em um mundo com racionalidade limitada e incerteza fundamental ${ }^{122}$. A fundamentação individualista e de escolha racional da economia neoclássica limita a capacidade dessa teoria para analisar a natureza incerta e coletiva do processo tecnológico que está no centro do desenvolvimento econômico.

O argumento das vantagens comparativas, além de ter evidências empíricas contestáveis, apresenta construção teórica que é discutível quando considerada a ação no tempo para reduzir as falhas de mercado. Para seguir as vantagens comparativas é preciso observar os preços relativos, os quais, no entanto, só estarão disponíveis depois do aprendizado e da intervenção estatal. A inviabilidade das firmas, quando há desvios frente à vantagem comparativa, é questionável em razão da teoria e da experiência histórica.

Também a concepção teórica da ortodoxia parece manter a noção do mercado de fundos de empréstimos, o que implica a necessidade de fomentar a poupança para o crescimento, como notado por Fonseca e Mollo (2013) e Mollo e Amado (2015). Na

${ }^{122}$ Como escreve Chang, em Lin e Chang (2009), "unless you actually enter the industry and develop it, it is impossible to know how long it will take for the country to acquire the necessary technological capabilities to become internationally competitive". 
tradição ortodoxa, para investir de forma a aumentar a capacidade produtiva, sem aceleração inflacionária, é preciso que haja poupança e que se abra mão de parte do consumo $^{123}$. Nesse sentido, uma política fiscal expansionista diminui a poupança pública, aumenta a taxa de juros e desloca o investimento privado, caracterizando o crowding-out. Como foi comentado no capítulo 1, essa visão ortodoxa pressupõe a noção de moeda neutra e o aspecto inflacionário da política fiscal. Fonseca e Mollo (2013) e Mollo e Amado (2015) ressaltam a crítica heterodoxa a essas noções e a possibilidade de atuação estatal no estímulo ao investimento.

Menos do que procurar imperfeições específicas e olhar o desenvolvimento pelo lado da oferta, outros paradigmas permitem passar do caráter falho à compreensão da natureza inerentemente desequilibrada, desigual e incerta do sistema econômico e da atuação estatal. Apesar de certa flexibilidade das aplicações da teoria neoclássica na formulação de políticas industriais, ainda há restrição a noções estreitas de eficiência. Os pressupostos da economia ortodoxa podem ser substituídos, em graus diferenciados, pelas tradições estruturalista, marxista e pós-keynesiana. Ainda que o estruturalismo tenha elementos ortodoxos, essa perspectiva se torna relevante por estar na origem das diversas correntes desenvolvimentistas e no pensamento sobre política industrial no Brasil.

\subsection{Estruturalismo latino-americano e experiências em política industrial}

O debate sobre desenvolvimentismo e política industrial no Brasil está associado, em suas raízes, ao pensamento estruturalista latino-americano. Para Mollo e Amado (2015), a análise estruturalista está na origem de várias perspectivas do chamado desenvolvimentismo no Brasil. Embora tenha elementos monetários ortodoxos, destacam as autoras, como a visão sobre necessidade de poupança prévia, o estruturalismo cepalino é heterodoxo quanto ao método, histórico-estrutural, utilizado na formulação teórica sobre os países periféricos para identificar os limites estruturais ao desenvolvimento, associados a progresso técnico, diversificação econômica e criação de mercado interno

${ }^{123}$ A preferência pelo consumo futuro pode diminuir o consumo presente, liberar recursos para financiar o investimento e, em consequência, garantir a produção futura desejada. 
dinâmico. Além dos elementos monetários ortodoxos, podem ser notadas concepções marginalistas em Prebisch (1951).

Nesta seção, são apresentados alguns aspectos considerados essenciais das formulações teóricas do estruturalismo latino-americano, no que diz respeito às proposições sobre mudança estrutural e industrialização. São evidenciados traços fundamentais do pensamento original dos autores clássicos e os elementos de continuidade nas proposições estruturalistas de política econômica.

\subsubsection{Proposições iniciais sobre política industrial}

As formulações teóricas clássicas da perspectiva estruturalista latino-americana encontram-se sintetizadas e documentadas em diversos estudos, entre os quais podem ser destacados os de Rodríguez (1981, 2009), Bielschowsky (1988, 2000), Blankenburg et al. (2008) e Palma (2008). A abrangente contribuição teórica e de política econômica produzida pelo estruturalismo tem diversas vertentes. Alguns aspectos podem ser salientados no que diz respeito às recomendações de política industrial dessa corrente.

Bielschowsky (2000) propõe periodização que permite o entendimento das principais mensagens veiculadas pela formulação estruturalista ao longo tempo, atentando-se para o caráter de corpo teórico unificado da perspectiva. No período 19481960, foram desenvolvidos os conceitos fundamentais e o método de análise históricoestrutural, apontando para a condução deliberada da industrialização na periferia. $\mathrm{Na}$ década de 1960, foram pesquisadas reformas destinadas a eliminar os obstáculos à industrialização. Nos anos 1970, foi procurada reorientação dos estilos de desenvolvimento em direção à homogeneização social e à industrialização próexportações. $O$ decênio seguinte foi marcado pela tentativa de superação do endividamento externo, por meio de ajuste com crescimento. A década de 1990 viu a formação de uma agenda de transformação produtiva com equidade, marcando também o início do neoestruturalismo na Cepal.

Os trabalhos iniciais do final da década de 1940 e da década de 1950 constituem marco precípuo da teorização posterior e conformam a base do pensamento estruturalista até os dias atuais, conforme argumentam Bielschowsky (1988, 2000) e Rodríguez (1981, 2009). As contribuições iniciais de Prebisch (1949, 1951a, 1951b) representam a base do

método estrutural, ao qual se soma a abordagem histórica das questões do 
desenvolvimento econômico. A concepção não é reducionista, ao analisar os fenômenos econômicos no marco mais amplo da realidade dos fenômenos sociais e políticos. $\mathrm{O}$ subdesenvolvimento na periferia não constituiria anomalia, mas sim um padrão de funcionamento dessas economias, o que requer elaboração teórica específica.

O método cepalino e estruturalista, ou seu sistema analítico, configura-se como método "histórico-estrutural". O método histórico-estrutural é central para a análise das condições da periferia ${ }^{124}$. Com efeito, esse método, segundo Bielschowsky (1988), teria sido epitomizado por Furtado em sua obra Formação econômica do Brasil (1959). Na concepção de Furtado (1961), a busca por níveis mais altos de abstração deveria ser acompanhada da definição da validade das relações inferidas em função de realidades históricas. A duplicidade fundamental da ciência econômica, seu caráter abstrato e histórico, aparece, assim, com toda a plenitude na teoria do desenvolvimento econômico. O subdesenvolvimento é um processo próprio que tende a perpetuar-se, na ausência decisiva de intervenção política, e não uma simples etapa de desenvolvimento pela qual passam todos os países.

De acordo com Bielschowsky (1988, 2000), a industrialização na periferia, no início das formulações de Prebisch e Furtado, assim como do pensamento estruturalista, era vista como um padrão de desenvolvimento singular e problemático. No centro, os padrões de demanda desenvolveram-se conjuntamente com as descobertas tecnológicas e com o aumento de renda, gerando maior homogeneidade setorial. Na periferia, o padrão seria independente do sistema produtivo, com os bens modernos sendo importados de acordo com a capacidade exportadora, e não permitiria acomodar processo acelerado de transformação. A perspectiva apontada por Prebisch imprimia caráter de desenvolvimento mais profundo das sociedades latino-americanas, ao propor a industrialização como meio para difundir o progresso técnico e o aumento da renda nos países periféricos. Seria a maneira de manter internamente os frutos do progresso técnico dos países periféricos.

Dessa maneira, a periferia herda uma base econômica especializada e com grande heterogeneidade estrutural. A economia é especializada em poucos produtos de exportação e apresenta complementaridade inter-setorial e integração vertical baixas. Igualmente, existe baixa produtividade em todos os setores, exceto o de exportação, fazendo com que a produtividade média per capita reduza a taxa de poupança, situação

${ }^{124}$ Boianovsky (2010) também destaca o papel fundamental de Furtado no debate sobre desenvolvimento econômico nos anos 1950. 
que se agrava com o consumo suntuoso das classes ricas. Essas características da periferia implicariam quatro tendências: desemprego, deterioração dos termos de troca, desequilíbrio externo e inflação.

Segundo Rodríguez (2009, p. 119), as recomendações de política econômica do estruturalismo são consistentes com seus fundamentos teóricos, mas não constituem apenas corolário dessa formulação, pois exigem ainda análises complexas, como a alocação de recursos, e uso de técnicas especiais, como o planejamento, o qual é destacado em Cepal (1955) ${ }^{125}$. Essas propostas surgem no contexto do intenso desenvolvimento industrial que se vinha produzindo em diversos países da América Latina desde a grande depressão e, especialmente, durante a Segunda Guerra Mundial e o imediato pós-guerra. Essa industrialização espontânea gerava desequilíbrios (desajustes inter-setoriais da produção e tendências à deterioração, ao déficit externo e ao subemprego), que seriam evitados por meio da condução deliberada da industrialização.

Para conduzir a industrialização, são propostos critérios de alocação de recursos que levam em consideração a distribuição do investimento entre o setor exportador, a manufatura e as demais atividades. Esses critérios abarcam os padrões de eficiência das diversas atividades produtivas, como a economicidade em relação às atividades correspondentes do centro, o que, segundo Rodríguez (2009), mostra como não era propugnada expansão excessiva e indiscriminada da indústria por um desejo de autossuficiência $^{126}$.

No campo das relações econômicas internacionais, as diversas recomendações de política defendem a cooperação internacional, adaptada aos países periféricos. Essa cooperação abrange a proteção ao mercado interno, a integração regional, o financiamento externo, a política anticíclica e de atenuação das flutuações de preços internacionais e a assistência técnica. A proteção seria necessária à industrialização da periferia e favoreceria também a expansão do produto e do comércio internacionais, diferentemente do que ocorreria no centro. Essa proteção viria associada a critérios de alocação eficiente de recursos e a uma perspectiva de retirada gradual. Já as vantagens da integração latino-americana eram consideradas fundamentais para a possibilidade de

\footnotetext{
125 Bielschowsky (2000) salienta que este texto foi escrito por Furtado, embora esteja apresentado, na coletânea, como sendo de autoria coletiva da CEPAL.

126 Rodríguez (2001) afirma que os documentos da CEPAL, sobretudo os relativos à técnica de planejamento, reconhecem a relevância do papel do mercado e admitem graus e tipos de intervenção distintos segundo casos diferenciados.
} 
exportar manufaturas para o resto do mundo, associando-se maior eficiência industrial e diversificação produtiva com a integração ${ }^{127}$.

O planejamento é considerado imprescindível para o objetivo de desenvolvimento no longo prazo, ao ser utilizado para articular as diversas medidas parciais e enfrentar os problemas estruturais. De acordo com Rodríguez (2009, p. 121), as técnicas de “planejamento modificam e estendem os critérios de alocação de recursos com o fim de racionalizar o esforço de investimento com o passar do tempo, adequando-o às grandes metas da política de desenvolvimento". O eixo central é a industrialização, conduzida para aumentar a produtividade e o emprego, evitar o desequilíbrio externo e minimizar as perdas devidas à deterioração dos termos de troca.

Nesse sentido, o planejamento deve atuar para melhorar o funcionamento da economia de mercado na periferia. Rodríguez $(2009$, p. 122) destaca que:

A necessidade da ação estatal, de contar com uma política de desenvolvimento deliberada e coerente e de implementá-la por meio do planejamento são três ideias-força do pensamento estruturalista estreitamente conectadas entre si. O planejamento não é considerado (...) um substituto da economia de mercado, mas um meio para dar maior eficiência ao seu funcionamento.

\subsubsection{Permanência e mudança no pensamento estruturalista recente}

O neoestrutralismo cepalino surge entre as décadas de 1980 e 1990, sob a influência dos trabalhos de Fajnzylber $(1983,1990)$, e se torna dominante a partir de 1990, com a perspectiva delineada no trabalho da Cepal (1990), conforme ressaltam Bielschowsky (2000, 2010) e Rodriguez (2009). Esta configuração teórica, argumenta Bielschowsky (2010), surge com a adaptação advinda das mudanças externas e internas, com a instabilidade macroeconômica derivada do fim do padrão de Bretton Woods na década de 1970 e com a reorientação das economias da região à globalização a partir do final dos anos 1980. Passar-se-ia a avaliar as oportunidades e desafios para o desenvolvimento em economias abertas e com estados menos intervencionistas.

\footnotetext{
$127 \mathrm{O}$ caso da integração pode ser notado, concretamente, nas proposições de acordos preferenciais de comércio entre países periféricos, as quais foram importantes para o surgimento da Associação LatinoAmericana de Livre Comércio (ALALC, criada em 1960) e a Associação Latino-Americana de Integração (ALADI, criada em 1980 e até hoje em vigor). Nesse contexto, e de maneira também associada ao trabalho e às concepções de Prebisch (ver, por exemplo, Palma, 2008), também surgem os sistemas gerais de preferências e a UNCTAD (Conferência das Nações Unidas para o Comércio e o Desenvolvimento, de 1964), a qual foi presidida, em seu início, pelo economista argentino.
} 
Igualmente, a ênfase no progresso técnico baseado na acumulação de conhecimento constituiria nova referência analítica na Cepal.

Fajnzylber (1983) contrasta a evolução do setor industrial entre países desenvolvidos, quatro tigres asiáticos e os países da América Latina. Diferentemente da perspectiva neoliberal, o autor mostra que os dois primeiros grupos mantiveram coordenação entre a intervenção do Estado e a operação das empresas privadas. Dessa forma, ao invés de identificar como problema a intervenção ou a opção pela industrialização, o autor destaca ações concretas como a falta de protecionismo direcionado ao aprendizado e a modalidade de industrialização realizada, que constituiria versão setorial e tecnologicamente inacabada ${ }^{128}$ daquela presente na matriz dos países desenvolvidos. Está ausente, nos países periféricos, a constituição de um núcleo endógeno de dinamização tecnológica, que é condição necessária para entrar e manter-se no mercado internacional. Assim, seria necessária inserção internacional baseada em competitividade sistêmica, com o fortalecimento das cadeias produtivas locais e a disseminação do progresso técnico, ao invés da competitividade chamada espúria, formada por desvalorizações cambiais, baixos salários e a destruição do meio ambiente. Além do progresso técnico, a diminuição da desigualdade de renda conformaria outra condição necessária ao desenvolvimento, conforme mostra Fajnzylber (1990) em outro estudo comparativo.

Já a perspectiva inaugurada pela Cepal (1990) recomendava maior abertura do comércio, de forma gradual, seletiva e sendo protegida por taxa de câmbio real elevada e estável. Dessa forma, pretendia-se o estímulo à competitividade sistêmica, com inovação, catching-up e fortalecimento da capacidade produtiva. Ao mesmo tempo, a equidade era considerada condição para melhorar a competitividade.

Bielschowsky (2010) relata que, ao invés de reagir negativamente às novas condições derivadas do contexto econômico e ideológico internacional, associado a reformas inspiradas no Consenso de Washington, o neoestruturalismo construiu agenda positiva para adaptação a essa nova realidade, com a revisão seletiva das reformas liberalizantes, mostrando alternativa ao neoliberalismo. Assim, Bielschowsky (ibid., p. 30) menciona a revisão da abertura financeira; o fortalecimento e a renovação das

\footnotetext{
${ }^{128}$ Nesse contexto, o autor reconhece o atraso no setor de bens de capital, que é fundamental para a geração do progresso técnico, assim como a falta de disposição ao risco e ao progresso técnico do setor empresarial, a falta de inovação nas filiais das empresas multinacionais, a ineficiente diferenciação de produtos e a limitada integração entre agricultura e indústria.
} 
políticas industriais, tecnológicas e de comércio exterior; a reorientação das reformas dos sistemas de seguridade social e dos desenhos de políticas sociais em diferentes áreas; o novo pacto fiscal, conciliando demandas sociais e higidez das contas públicas; e a sustentabilidade ambiental.

Os pontos de continuidade entre estruturalismo e o neoestruturalismo foram considerados numerosos por Bielschowsky $(2010)^{129}$. Permanece o diagnóstico central de que existe, na América Latina, especialização inadequada, com insuficiente diversificação na produção e nas exportações, o que implicaria escassez de divisas e vulnerabilidade externa. Esses fatores perpetuariam a heterogeneidade estrutural e, consequentemente, limitariam o aumento da produtividade e o crescimento. A proximidade entre as duas correntes é mais intensa no que tange ao desenvolvimento produtivo e à inserção internacional pelo comércio, assim como na análise do emprego, da pobreza e da distribuição de renda.

Uma inovação analítica que parece fundamental no pensamento neoestruturalista é a fusão entre as abordagens estruturalista e schumpeteriana ${ }^{130}$, salienta Bielschowsky $(2010)^{131}$. Essa fusão teve origem nos estudos Fajnzylber citados e foi aperfeiçoada por autores como Ocampo e Cimoli. Ganha força a avaliação de que o crescimento da renda per capita está associado à mudança na composição do PIB e nas modalidades de inserção no comércio mundial, ponto que já estava presente na perspectiva estruturalista clássica. Cabe destacar também que o argumento acerca dessa convergência de ideias está amparado pela inclinação das duas correntes à análise histórica da atividade produtiva, situação em que os conceitos de dependência da trajetória (path-dependence), aprendizagem e paradigmas tecnoeconômicos enriquecem a compreensão das

\footnotetext{
${ }^{129}$ Ainda assim, Rodríguez (2009) nota certa aproximação, na década de 1990, com argumentos extraídos da economia convencional, como falhas de mercado e determinadas carências institucionais nos problemas de desenvolvimento. Haveria dupla tendência nesse período, ao serem verificadas a vertente do industrialismo original e da versão de Fajnzylber, mas também (ibid., p. 37) "certa aproximação com pontos de vista neoclássicos aflora nos documentos mencionados, na medida em que eles incluem e enfatizam recomendações atinentes ao fomento da livre concorrência e relativizam a necessidade da intervenção estatal, admitindo a conveniência de se acentuar a desregulação dos mercados em diversos âmbitos." Ainda assim, a partir do final dos anos 1990 retomam força certas tradições do estruturalismo.

130 Bielschowsky menciona o termo schumpeteriano, no entanto, é possível utilizar os termos neoschumpeteriano ou evolucionário para caracterizar essa abordagem, derivada dos programas de pesquisa associados aos estudos presentes em Dosi et al. (1988).

131 Outros estudos também salientam pontos de convergência entre o pensamento estruturalista e a abordagem neoschumpeteriana, como Albuquerque (2007), que argumenta como o diálogo entre o conceito de inadequação da tecnologia de Celso Furtado e o de sistemas nacionais de inovação pode enriquecer o entendimento dos problemas relacionados ao desenvolvimento de sistemas de inovação na periferia, e Amado e Resende (2007), que destacam as contribuições Fajnzylber e as diferenças entre os sistemas nacionais de inovação da periferia e do centro.
} 
transformações das estruturas produtivas subdesenvolvidas e com heterogeneidade estrutural.

Esse enfoque enfatiza a importância do comércio exterior na determinação do potencial de crescimento sustentável a médio e longo prazos, como se nota em Cepal (2007). A convergência teria como restrição fundamental o comportamento das elasticidades de exportações e importações, que definem o crescimento potencial que não restringe o balanço de pagamentos ${ }^{132}$. Essas elasticidades seriam definidas pelo crescimento relativo da produtividade dos países em desenvolvimento com respeito aos desenvolvidos. Já esse aumento seria avaliado pelo hiato tecnológico das estruturas produtivas e por características tecnológicas que influenciam a competitividade (financiamento, instituições, tarifas, etc.). De modo geral, a convergência está limitada pelo ritmo com que se introduz e dissemina o progresso técnico na estrutura produtiva, em relação aos países avançados, processo que depende de mudanças na composição setorial do produto e da intensidade do processo inovador setorial.

Considerando a ação estatal, nota-se que, segundo Bielschowsky (2010, p. 52), "la CEPAL en la actualidad recomienda que el Estado preserve un papel relevante en la vida económica; no necesariamente menor, sólo diferente." Quanto à estrutura produtiva, nota-se que a proposta de industrialização para combater os problemas associados ao subdesenvolvimento (inserção internacional inadequada, estrangulamentos externos, crescimento escasso e instável, desemprego e pobreza, divergência internacional) encontra proximidade com a reflexão atual. O neoestruturalismo defende estratégia de mudança estrutural que se articula conceitualmente com as ideias de diversificação produtiva e exportadora. Essa estratégia seria incentivada pela agregação de valor por meio da inovação e estimulada pela ampliação e pelo fortalecimento do tecido produtivo. Embora a perspectiva atual admita exageros nas políticas protecionistas antes adotadas e observe pontos positivos nos processos de abertura ocorridos ${ }^{133}$, a análise neoestruturalista reconhece a necessidade de que o Estado deva utilizar-se de políticas produtivas, tecnológicas e comerciais que melhorem a qualidade da inserção internacional dos países em desenvolvimento.

\footnotetext{
${ }^{132}$ Esse estudo apresenta clara influência das pesquisas vinculadas ao modelo de crescimento com restrição no balanço de pagamentos com referência em Thirlwall (1979).

${ }^{133}$ Notem-se as ressalvas anteriores, de que os processos, idealmente, deveriam ser competitivos e graduais.
} 
A possibilidade de convergência das correntes estruturalista e schumpeteriana pode ser ressaltada em seus aspectos heterodoxos e evolucionários mais importantes no que diz respeito às políticas industriais.

Peres e Primi (2009) defendem que há significativas possibilidades de síntese ou convergência entre diversas correntes que constituem alternativa à posição neoliberal, a qual confia nos mecanismos de ajustamento do mercado. Os autores identificam a ocorrência de síntese entre as visões schumpeteriana, evolucionária e estruturalista (cepalina), segundo a qual existiria espaço para a intervenção privada e pública no desenvolvimento industrial ${ }^{134}$.

A explicação para a política industrial está no mecanismo ex ante de coordenação que, em função da incerteza quanto ao futuro e do caráter não determinístico do progresso técnico, a eficácia, o atingimento de objetivos públicos estratégicos nacionais, seria mais importante do que a eficiência, calculada conforme balanço de custos e benefícios. A preocupação com a economia verificada na realidade e reconhecimento da falta de mecanismos de ajuste automáticos, como é importante na perspectiva evolucionária, não requer a noção de falhas de mercado para a atuação estatal. A base na realidade das características do sistema econômico, sujeito a incertezas associadas ao processo de inovação e disseminação tecnológica, compõe a principal característica dessa síntese, o que se afasta do neoliberalismo e também da base teórica neoclássica.

Peres e Primi (2009) listam diversas áreas potenciais de intervenção governamental com base na visão evolucionária. As capacidades do sistema produtivo e tecnológico podem ser estimuladas, como infraestrutura física e institucional, bem como recursos humanos, ambiente de negócios, criação de oportunidades científicas e técnicas e de capacidades tecnológicas dos agentes. $\mathrm{Na}$ infraestrutura institucional e na organização e estrutura de mercado, podem ser notadas políticas como os bancos de desenvolvimento e políticas de competitividade, nacionalização de firmas e desenvolvimento de campeões nacionais. A perspectiva evolucionária, em síntese com o estruturalismo, entende como possíveis as políticas que amiúde são consideradas como distorção exagerada no mecanismo de mercado, mas pertencem ao escopo da criação de capacidades por causa da coordenação para os objetivos nacionais.

\footnotetext{
134 Peres e Primi (2009) incluem na síntese autores como Stiglitz. Talvez no nível da prática haja concordância quanto à necessidade de políticas e a abertura para utilização de diversos instrumentos por esse autor, no entanto, como observado, existem diferenças da abordagem neoclássica de Stiglitz e dos autores estruturalistas e schumpeterianos, ainda que haja importantes trabalhos em conjunto, como Cimoli et al. (2009), em que prevalece a visão evolucionária.
} 
O Estado pode incentivar o desenvolvimento e, conforme determinado contexto, envolver-se diretamente na produção, financiando-a por meio de desonerações e subsídios, ao mesmo tempo em que pode atuar como articulador de políticas formuladas para promover ligações entre agentes. Na política industrial (ibid., p. 14),

the State might play different roles. There are four main types of State interventions in support of industrial development: (i) As regulator, e.g., by setting tariffs and production levels for certain activities, or by creating fiscal incentives or subsidies to support industrial sectors. (ii) As producer, participating directly in economic activity, as in the case of State-owned enterprises. (iii) As consumer, ensuring a market for strategic industries and economic activities through public procurement programs. (iv) Finally, as a financial agent and investor, influencing the credit market and promoting the allocation of public and private financial resources to industrial projects considered strategic because of their impact on productivity, or because of their capacity to absorb labor."

O conceito de sistema nacional de inovação é importante para entender a criação de capacidades e o desenvolvimento. Esse sistema constitui "the network of institutions in the public and private sectors whose activities and interactions initiate, import, modify and diffuse new technologies", de acordo com Freeman (1987). As contribuições ao estudo do desenvolvimento econômico, como mostram Fagerberg et al. (2010), têm cada vez mais ressaltado o papel da atividade inovadora e da aquisição de capacidades no crescimento e na diversificação produtiva. Com efeito, conforme pesquisou Albuquerque (1999), sistemas de inovação menos desenvolvidos estão associados a países com menor desenvolvimento econômico. Fagerberg et al. (2007), por exemplo, estimam que as divergências de renda são derivadas, principalmente, de aspectos como tecnologia e capacidade de utilizar tecnologias existentes.

\subsubsection{Estado como empreendedor e políticas industriais na história}

Adicionalmente às noções teóricas, tem-se desenvolvido abordagem histórica e de estudos de caso que mostram como a atividade governamental se encontra sempre presente no desenvolvimento econômico, mesmo em países de extração liberal. Parece importante entender a atuação do Estado também como empreendedor no desenvolvimento produtivo das economias.

O caso dos países em desenvolvimento, que contraria dotações iniciais e preços de mercado, tem diversos pesquisas bem conhecidas. Wade (1990), por exemplo, avalia que os estados desenvolvimentistas exitosos do Leste Asiático como Taiwan, Coreia do 
Sul e Japão tentaram governar o mercado e frequentemente lideraram, ao invés de seguir, o mercado e as preferências dos agentes econômicos, gerando novas capacidades, em especial em setores intensivos em capital. Wade (1990, p. 342) nota que:

the central economic mechanism of the capitalist developmental state is the use of state power to raise the economy's investible surplus; insure that a high portion is invested in productive capacity within the national territory; guide investment into industries that are important for the economy's ability to sustain higher wages in the future; and expose the investment projects to international competitive pressure whether directly or indirectly.

No caso dos países latino-americanos, diversas medidas possibilitaram a industrialização. Peres e Primi (2009) notam que a industrialização por substituição de importações priorizou a criação de novos setores, para promover a diversificação da estrutura produtiva e mudar o padrão de especialização. Também houve tentativa de endogeneizar os efeitos do crescimento da demanda interna para investimentos, bem como evitar crescimento das importações e mitigar o déficit da balança comercial. A crise da dívida na década de 1980 e a mudança de perspectiva desenvolvimentista na década de 1990 reduziram a importância das políticas industriais. No entanto, Peres e Primi notam retomada dessas políticas na década de 2000 .

A partir do estudo das experiências históricas dos países hoje mais desenvolvidos, podem ser questionadas recomendações de política recente de menor intervenção estatal. Chang (2002), por exemplo, empreende pesquisa que reconstitui estratégias de desenvolvimento em perspectiva histórica e desmistifica a visão convencional sobre a ausência de políticas industriais em países supostamente liberais. Quase todos os países exitosos utilizaram-se de proteção à indústria nascente e outras políticas industriais, comerciais e tecnológicas enquanto realizavam o catching-up. Países como o Reino Unido não teriam sido economia de livre comércio e laissez-faire, ao mesmo tempo em que os EUA podem ser considerados o bastião e a origem do protecionismo moderno.

Chang (2002) chama a atenção para uso mais diversificado de instrumentos, além das tarifas, como subsídios às exportações, créditos tributários na exportação, direitos de monopólio, formação de carteis, créditos direcionados, planejamento de investimentos e das necessidades de força de trabalho, apoio a P\&D e a promoção de instituições que permitem cooperação público-privada ${ }^{135}$. No entanto, diversos desses instrumentos estão

${ }^{135}$ Chang (2002, p. 65) atesta que "Tariffs were not, and are not, the only policy tool available to a state intent on developing new industries or upgrading old ones. In some countries, such as Germany up to the 
proibidos pelas regras do regime de comércio internacional contemporâneo, associado à OMC.

Também os países desenvolvidos parecem estar adotando políticas de reindustrialização na história recente, após décadas de outsourcing e fragmentação produtiva das firmas associadas a esses países. Os EUA podem constituir exemplo de economia cuja prática está associada ao desenvolvimentismo, apesar de discurso liberal arraigado.

Block (2008) argumenta que os EUA constituem um "hidden developmental state", com influência significativa sobre a economia. Há atuação dentro das normas da OMC no apoio ao desenvolvimento de $\mathrm{P} \& \mathrm{D}$ para firmas iniciantes que produziriam primeiramente para o mercado interno e depois para o externo. As start-ups poderiam ser empresas parcialmente estatais que receberiam recursos de fundos de venture capital públicos e privados e bancos internacionais de desenvolvimento. $\mathrm{O}$ autor reconhece que existe profunda desvinculação entre o que o os EUA fazem internamente, sem muita visibilidade $^{136}$, e as políticas econômicas que pretende impor ao resto do mundo, por meio do Consenso de Washington e do fundamentalismo de mercado. Nos EUA, há diferenciação entre firmas estrangeiras e nacionais, com apoio a setores nacionais, por meio de diversas redes. Dessa forma, observa-se um "highly decentralized Developmental Network State".

Um exemplo de participação disfarçada do Estado no desenvolvimento pode ser encontrado contemporaneamente no exemplo dos EUA. Wade (2014) argumenta que os EUA constituem um Estado desenvolvimentista disfarçado, apesar da paradoxal defesa do governo americano e da visão arraigada de que o país seria símbolo de não intervencionismo. Mesmo a partir da virada neoliberal com Reagan, o discurso de laissezfaire, na prática, foi acompanhado de políticas industriais ativas. Desde o final dos anos 1990, diversas agências governamentais americanas estabeleceram fundos de venture capital, destinados não a lucro, mas a alavancagem financeira para induzir o

late nineteenth century or Japan before the restoration of its tariff autonomy in 1911, tariff protection was not even the most important tool for infant industry promotion".

${ }^{136}$ Essa menor visibilidade não implica ausência de relações conflituosas quanto à necessidade de dispender recursos para manter atividades de fomento em meio a ideológicas sobre a intervenção governamental. Para Negoita (2011), a atuação do Advanced Technology Program (ATP), vinculado ao Department of Commerce dos EUA, revela como o governo desse país pratica políticas de fomento a empresas e tecnologias escondidas por trás do discurso do fundamentalismo de mercado. Para o autor (2011, p. 77), "as a result of the dominant neoliberal bias against government intervention, much of the energy institutions like the ATP could be using to increase efficiency and forge institutional connections is spent instead to deflect attacks and survive." 
desenvolvimento e a adaptação de tecnologias comercialmente viáveis segundo a necessidade da agência. A evidência atual é de que os EUA praticaram políticas industriais em escala significativa, mas não de maneira coordenada, nem proveniente de planos nacionais. Essa forma descentralizada de política industrial constituiria uma vantagem, atuando também para promover o êxito de redes de produção e inovação.

Nos EUA, mais recentemente, o discurso State of the Union de 2013 enfatizou a recuperação da indústria de transformação nos empregos, desenvolvimento tecnológico e exportações que mostram inclinação recente para a reindustrialização da economia. São propostas diversas medidas, como: a criação de institutos de inovação na indústria, em parceria com empresas, universidades e comunidades, para construir "manufacturing technologies and capabilities"; o fim de isenções fiscais e oneração para empregos criados no exterior pelo offshoring; parcerias com entes subnacionais, como no programa SelectUSA, para atrair indústrias e cadeias de fornecedores; confirmação da liderança em energias limpas e setor automotivo avançado, assim como aumentar o P\&D federal para innovative, advanced manufacturing technologies ${ }^{137}$.

$\mathrm{Na}$ história recente, a prática de políticas de desenvolvimento produtivo parece disseminada entre os países mais desenvolvidos sob a denominação de políticas de inovação. Em estudo da OCDE (2011), são notadas diversas ações entre países europeus no que diz respeito a chamadas políticas de inovação pelo lado da demanda, relacionadas a ações direcionadas em compras públicas, regulação, padrões e políticas para o consumidor, além iniciativas lideradas pelos usuários e para mercados líderes. Dessa forma, as políticas "address market and system failures in areas in which social needs are pressing”. A OCDE (ibid., p. 9) identifica que a prática disseminada dessas medidas em países desenvolvidos e economias emergentes, como Brasil e China, resulta de maior reconhecimento das interações entre oferta e demanda no processo de inovação, de evolução para abordagem mais ampla do ciclo de inovação (para além do modelo linear) e de percepção geral de que "traditional supply-side policies - despite refinements in their design over recent decades - have not been able to bring innovation performance and productivity to desired levels", bem como de melhoria da produtividade do gasto público em políticas inovadoras e associadas a demandas sociais.

${ }^{137}$ Entre esses investimentos em P\&D estão: processos inovadores que reduzem o uso de energia aumentam o uso de platform technologies, como nano-manufacturing, bio-manufacturing, robotics (pelo National Robotics Initiative), advanced materials (pelo Materials Genome Initiative) tecnologias na área de defesa, para reduzir também o tempo de desenho até a produção. 
Dessa forma, parecem existir diversos elementos para entender o caráter empreendedor do Estado no capitalismo. Mazzucato (2013) organizou argumentos históricos e teóricos sobre o papel do Estado como empreendedor, não apenas na estabilização macroeconômica e nas políticas microeconômicas voltadas para diminuir falhas de mercados. Compreende-se que o Estado pode ser um criador de mercados e atuar diretamente na inovação e no estímulo a atividades consideradas importantes e que fomentam outras inovações no setor privado e na economia. A perspectiva de Mazzucato, que incorpora as noções de sistemas de inovação, defende visão sistêmica sobre a atuação estatal para agir quando a iniciativa privada não tiver interesse ou houver custo e incertezas muito elevadas. O setor privado (ibid., p. 69) "is in many ways less entrepreneurial than the public sector: it shies away from radically new products and processes, leaving the most uncertain investments to be first taken on by the State".

No desenvolvimento, é importante a atuação para projetos de grande capacidade mobilizadora. Mazzucato (2015) expõe que a coordenação público-privada para novas redes e processos técnicos e econômicos que criam novos mercados está associada ao papel dos investimentos orientados para determinado objetivo (mission-oriented investments). Pode-se excluir a justificativa de falhas de mercado, que descreve estado estacionário no qual a política pública deveria consertar trajetórias existentes dos mercados. Essa justificativa torna-se pouco útil quando a política é necessária para criar e modelar dinamicamente novos mercados e não permite explicar os investimentos transformadores, catalizadores e mission-oriented que no passado criaram novas tecnologias e setores. Assim, o Estado pode determinar a direção da mudança técnica ao vislumbrar e escolher estrategicamente trajetórias inovadoras.

No caso dos investimentos em inovação, como Mazzucato (2013) aponta, seguindo Keynes, o investimento empresarial é função mais dos "animal spirits". Esse investimento é menos impactado por reduções de impostos do que pelo sistema de inovação, crédito ou qualidade da educação. Nos EUA, cortes de impostos não produziram mais investimento em inovação, afetando apenas a distribuição de renda. Assim, regiões com incentivos fiscais e menor regulação não são regiões de inovação, mas sim aquelas localidades em que o Estado está gastando para criar confiança sobre as possibilidades de crescimento futuro, como parques científicos.

A relação entre os riscos e os benefícios da capacidade estatal deve ser ponderada para que haja retorno significativo para a sociedade. Exemplos de incentivos realizados 
pelos EUA ${ }^{138}$ revelam que o Estado pode atuar na socialização do risco, ao intervir para criar mercados que não surgiriam espontaneamente por causa da incerteza. Mazzucato (p. 20-21) apresenta argumento em favor de um:

targeted, proactive, entrepreneurial State, one able to take risks and create a highly networked system of actors that harness the best of the private sector for the national good over a medium - to long-term time horizon. It is the State acting as lead investor and catalyst which sparks the network to act and spread knowledge. The State can and does act as creator, not just facilitator of the knowledge economy.

No entanto, também é central para a autora a noção de que os incentivos concedidos devem retornar à sociedade, para que se produza massa de recursos para financiamento contínuo da inovação e o empreendedorismo governamental e para que não se tenha privatização dos benefícios como resultado da ação estatal.

\subsection{Perspectivas marxistas e keynesianas no desenvolvimento produtivo}

Além do pensamento estruturalista e evolucionário, podem ser notadas algumas noções sobre a prática de políticas industriais e de desenvolvimento produtivo em perspectivas baseadas nos elementos teóricos em Marx e Keynes. Embora com aspectos diferenciados para cada tradição teórica, as contribuições associadas a esses últimos autores podem ser relevantes para o debate desenvolvimentista.

\subsubsection{Perspectivas marxistas sobre o Estado}

Para Marx, o desenvolvimento produtivo está associado à expansão da relação de capital sobre outras formas de organização social e ao crescimento das forças produtivas em virtude do imperativo da acumulação. Esse processo tende a ser desequilibrado, sujeito a diversas formas de interrupções e crises e concentrador de renda e riqueza.

\footnotetext{
${ }^{138}$ As instituições que atuam com capital paciente e comprometido com o longo prazo. Nos EUA, como Defense Advanced Research Projects Agency (Darpa), National Institutes of Health (NIH), National Science Foundation (NSF), National Aeronautics and Space Administration (NASA), os programas de Small Business Innovation Research (SBIR), a iniciativa nacional de nanotecnologia, entre outras.
} 
Também devem existir diferenças significativas no espaço e na estrutura da economia mundial e das economias nacionais. A atuação estatal se torna essencial ao sistema, mas demonstra importante complexidade.

O desenvolvimento das forças produtivas, que gera maior capacidade aumentada de produção de bens e serviços para satisfazer as necessidades humanas, pode ser limitado frente às relações de produção que implicam desigualdade e concentração. A expansão do modo de produção de capitalista pela economia mundial não implica desenvolvimento igual entre os países ou dentro de suas fronteiras. Os benefícios do desenvolvimento podem ser relativizados em razão do caráter concentrador, da alienação e da possibilidade de piora na relação capital-trabalho.

O Estado parece precipuamente associado à economia. Ações e a regulação do Estado sobre o todos os elementos dos circuitos ou ciclos do capital adquirem maior ou menor relevância. Em especial, é comum notar também participação estatal na infraestrutura econômica e social, influenciando os custos do capital constante e do capital variável. Menos do que considerar um cálculo para incorporar custos ou benefícios a mercados que de outra forma seriam perfeitos e atuar para corrigir esses defeitos, podese compreender da teoria em Marx que o Estado exerce influência na manutenção do sistema como um todo, de seus grupos hegemônicos e do processo de acumulação. A ação direta também pode ser exercida por meio de empresas estatais ou outras formas de composição patrimonial em firmas com interesse e condução governamental.

As funções econômicas aparentemente heterogêneas do Estado, segundo Poulantzas (1978), devem ser compreendidas em sua articulação orgânica. O Estado atua na sustentação do lucro das economias. Existe ação para desvalorização de parcela do capital constante, para elevar a taxa média de lucro e alta da taxa de exploração de maisvalia, principalmente pelo aumento da mais-valia relativa e, portanto, da produtividade do trabalho Para Poulantzas, a principal ação seria mesmo na reprodução ampliada da força de trabalho, via qualificação, pesquisa científica, inovações tecnológicas, seguridade, moradia, entre outras. É condição para a existência do Estado a garantia de núcleo sólido das relações de produção capitalistas, assegurando a exploração, ou seja, a exclusão dos reais poderes destes sobre os meios de produção.

O Estado tem influência histórica determinante sobre a formação do mercado de trabalho, do mercado monetário e diversas outras formas de regulação da atividade econômica. De acordo com Brunhoff (1985), são muito significativas as formas de intervenção estatal sobre duas mercadorias no circuito do capital, a moeda e a força de 
trabalho. A política monetária afeta o dinheiro, o qual precisa de uma ação externa e de intermediação do Estado que seja superior aos interesses privados e não se confunda com eles. A gestão da força de trabalho almeja a responsabilidade sobre a parte do valor da mão de obra que os capitalistas não remuneram diretamente, que corresponde às formas de assistência social e aos desempregados e de previdência ${ }^{139}$. A atuação sobre a força de trabalho associa-se à regulação do mercado de trabalho, sem suprimir a insegurança da força de trabalho.

No caso da ação estatal, Mollo (2001) argumenta que a necessidade do Estado, e de sua separação da sociedade, pode ser derivada das relações sociais do modo de produção capitalista, quanto à moeda e às relações de exploração. O dinheiro é validador social dos trabalhos privados e precisa de agente que seja distinto e não se confunda com interesses particulares, para o funcionamento do sistema capitalista. A relação de capital também constitui relação social em que deve ser garantida a venda de força de trabalho, cuja regulação deve ser realizada pelo Estado, que aparece como neutro nesse vínculo de exploração. Assim, o Estado atua de maneira externa, mas imanente, expõe Mollo.

A atuação do Estado no sistema capitalista, para os marxistas, é limitada. A ação estatal não pode acabar com as crises. Para Poulantzas (1978), o Estado não pode absterse de controlar o núcleo central da economia, mas também não consegue dominar os efeitos da sua própria ação na economia, ao fazer intervenções produtoras de crise e insuficientes, pois não atinge as causas profundas da crise.

As intervenções sobre a força de trabalho e a moeda mudam ao longo do tempo, nota Mollo (2001). Essas ações estatais atendem a diferentes necessidades históricas. Em períodos como os do pós-guerra, ocorreu intervenção maciça em investimentos e crédito. Já o neoliberalismo, embora não negue a necessidade da ação estatal, está associado à retirada do Estado da economia em razão da estratégia de acumulação ${ }^{140}$.

Ainda que tenha influência decisiva, o Estado não atua de maneira automática sobre o desenvolvimento do capitalismo. Como mencionado no capítulo 1, não é simples braço da burguesia. Pode-se entender também que não é simples defensor da burguesia de maneira abstrata, se bem que mantenha seu caráter de classe. O Estado pode responder

\footnotetext{
${ }^{139}$ Essa remuneração associa-se à regulação do mercado de trabalho, sem suprimir a insegurança da força de trabalho.

${ }^{140}$ Para Poulantzas (1978), a participação do Estado na acumulação e reprodução do capital é característica do capitalismo e perpassa regimes ou formas específicas. Essa característica não é própria apenas capitalismo monopolista sobre o qual escrevia à época, uma vez que o capitalismo liberal também tinha papel econômico. O Estado não tem papel econômico como resultado apenas de acumulação unilinear de diversas funções econômicas.
} 
a disputas hegemônicas entre frações do capital e os trabalhadores. De acordo com Poulantzas (1978), a figura do bloco no poder, o grupo ou fração de classe no controle do aparelho de Estado, está inserida em relação de poder cambiável no tempo e de acordo com as forças relativas dos grupos em disputa.

O Estado, para Poulantzas (ibid.), tem papel principal de organização em relação às classes dominantes, ao representar o bloco no poder, composto por uma ou mais frações de classe burguesas. Essa coesão pode ser caracterizada por conflito e equilíbrio instável entre seus componentes, que buscam hegemonia (como os capitais comercial, industrial, financeiro ${ }^{141}$. O Estado constitui unidade política das classes dominantes apenas se detiver autonomia relativa frente às frações de classes e interesses particulares. Essa autonomia existe pela separação relativa do Estado frente às relações de produção.

Dessa forma, apesar das diferentes perspectivas sobre o Estado e o desenvolvimento entre os marxistas, como no debate entre Poulantzas e Miliband, é possível depreender abordagem que destaca a ideia de autonomia relativa do Estado com relação às classes sociais. Essa consideração permite, do ponto de vista teórico, a compreensão de que o Estado pode agir em algumas estruturas na economia e na melhoria das condições dos trabalhadores ou de sua posição na relação capital-trabalho. Essa perspectiva sobre o papel do Estado justifica a defesa do desenvolvimentismo por alguns marxistas, como apontam Mollo e Amado (2015). Na disputa de política econômica com o liberalismo, para Mollo (2001), é possível buscar, em razão da autonomia relativa do Estado, formas de aumentar a regulamentação da economia. A redução de salários pela concorrência e a liberalização pode ser contestada pelos trabalhadores em função dessa autonomia relativa ${ }^{142}$, sem que seja eliminada a exploração e a atuação estatal na manutenção desse traço do sistema.

Com efeito, segundo Mollo (2001), a justificativa da luta contra o liberalismo direciona-se para reduzir o custo social sobre os trabalhadores do receituário liberal e do processo de acumulação capitalista em geral e para organizar e desenvolver a luta de classes, não apenas resistindo ao capitalismo, mas buscando organizar-se de forma participativa e solidária. A construção de processos sociais e coletivos, em contraposição

\footnotetext{
${ }^{141}$ No caso contemporâneo, Chesnais (2010) aponta como fração dominante do capital o capital financeiro. ${ }^{142}$ Embora seja comum a contradição entre acumulação e aumento de salários em modelos marxistas, foi discutido no capítulo 2 que pode haver aumento dos salários no processo de acumulação. Essa possibilidade de aumento do salário real e crescimento da acumulação pode ser notada na perspectiva de Marx, de acordo com Rosdolsky (2001).
} 
às ações individualistas, conforma também meio de aumentar a capacidade de organização dos trabalhadores.

A perspectiva marxista desenvolvida permite entender o caráter complexo da atuação estatal e a possibilidade de intervenção sobre a realidade para melhorar as relações capital-trabalho. É possível compreender também que os trabalhadores podem atuar na definição de políticas que aumentem o nível de emprego e renda da economia. As políticas keynesianas e desenvolvimentistas podem, quanto a esse aspecto, ser apoiadas pelos marxistas. Determinadas coalizões políticas, em especial com o capital produtivo ou industrial, podem ser buscadas para o crescimento e o emprego.

\subsubsection{Políticas keynesianas}

Alguns elementos da perspectiva Keynes e dos pós-keynesianos podem auxiliar a compreensão sobre políticas de desenvolvimento produtivo e a discussão brasileira. Políticas específicas podem ser inferidas das proposições vinculadas a essa perspectiva. São conhecidas as falhas graves identificadas por Keynes (1936, capítulo 24) na sociedade econômica, relacionadas à sustentação do pleno emprego e à distribuição de riqueza e renda.

$\mathrm{Na}$ perspectiva de Keynes, questões distributivas são significativas no comportamento social. Diferentes propensões a consumir associadas a parcela de renda muito concentrada nos mais ricos pode ter efeito de redução no nível de consumo na economia, dessa maneira com resultados deletérios sobre a demanda agregada e a formação de capital. Também a herança de riqueza, como não é resultado de nenhum esforço ou capacidade individual, mas somente da propriedade, gera desigualdades que deveriam ser corrigidas, ao passo que as diferenças derivadas de habilidades e ações individuais no exercício da atividade empreendedora seriam saudáveis ${ }^{143}$. Carvalho (1992) argumenta que Keynes sempre defendeu que deveriam ser estabelecidos impostos sobre heranças e direitos de propriedade de ativos ${ }^{144}$.

\footnotetext{
${ }^{143}$ Implícita nessa noção está a valorização da atividade empreendedora, como notado no capítulo 2. Como resume Minsky (1975, p. 149), "Keynes viewed the inequality of income that results from enterprise (mainly capital gains) as desirable, but the inequality of income that results from the "pure" ownership of wealth (the income of rentiers) as undesirable".

${ }^{144}$ Em determinadas circunstâncias, ativos poderiam também ser redistribuídos em favor de grupos de menor renda. Carvalho (1992) exemplifica essas medidas redistributivas nos casos da discussão de Keynes sobre o Plano Beveridge e do empréstimo compulsório no início da Segunda Guerra Mundial, que envolviam redistribuição de ativos em benefício de grupos de menor renda, por meio de taxação de capitais.
} 
No caso do nível de emprego na economia, Keynes identificou a necessidade de o Estado intervir para sustentar o nível de investimento. A economia não apresenta mecanismos automáticos para levar ao pleno emprego. As firmas, reproduzindo posturas defensivas, podem demandar nível de investimento insuficiente em razão de incerteza excessiva quanto ao dispêndio de recursos em ativos ilíquidos cujos rendimentos esperados podem não realizar-se. A preferência por formas mais líquidas de riqueza pelos agentes pode influenciar negativamente a demanda efetiva e a acumulação na economia.

Com efeito, Keynes, na Teoria Geral (1936, p. 378), procura avançar a noção de que o investimento deve ser socializado na economia assim como. Outras políticas podem não ser suficientes ${ }^{145}$. O espaço existente para satisfazer a demanda efetiva que utiliza os recursos ociosos na economia pode ser preenchido pelo investimento público, sem que outras formas de cooperação público-privada sejam excluídas. Assim, Keynes advoga que:

a somewhat comprehensive socialisation of investment will prove the only means of securing an approximation to full employment; though this need not exclude all manner of compromises and of devices by which public authority will co-operate with private initiative. (...) If the State is able to determine the aggregate amount of resources devoted to augmenting the instruments and the basic rate of reward to those who own them, it will have accomplished all that is necessary.

Na concepção de Keynes, o aumento do volume agregado do investimento e do produto, menos do que a alocação ou direcionamento do investimento, seria o objetivo do governo $^{146}$.

A socialização do investimento asseguraria aproximação ao pleno emprego, por meio da definição do montante de recursos agregados e para incrementar os meios de produção e sua remuneração básica para quem os detêm. Assim, "The central controls necessary to ensure full employment will, of course, involve a large extension of the traditional functions of government" (ibid., p. 379) ${ }^{147}$. A visão prospectiva do Estado

\footnotetext{
${ }^{145}$ Keynes (1936, p. 378) refere-se especificamente à necessidade de uma guiding influence do governo sobre a propensão a consumir, por meio da política tributária e da fixação da taxa de juros. Também a política monetária quanto à taxa de juros pode não conduzir a taxa de investimento suficiente.

${ }^{146}$ A familiar noção de Keynes (1936, p. 378-79) sobre a validade da teoria (neo)clássica no nível de pleno emprego justificaria o fim de intervenções a partir desse ponto: "if our central controls succeed in establishing an aggregate volume of output corresponding to full employment as nearly as is practicable, the classical theory comes into its own again from this point onwards". Igualmente, "apart from the necessity of central controls to bring about an adjustment between the propensity to consume and the inducement to invest, there is no more reason to socialise economic life than there was before".

${ }^{147}$ Esse processo deveria ocorrer de maneira gradual, sem representar quebra nas tradições da sociedade.
} 
sobre a eficiência marginal do capital é significativa para a atuação na organização do investimento ${ }^{148}$ :

I expect to see the State, which is in a position to calculate the marginal efficiency of capital-goods on long views and on the basis of the general social advantage, taking an ever greater responsibility for directly organising investment.

A defesa da atuação estatal empreendida por Keynes seria necessária para impedir a destruição da economia de mercado e garantir a iniciativa individual, ainda que possam aparentar investida contra a liberdade individual. $\mathrm{O}$ autor (ibid., p. 380-81) exprime que:

Whilst, therefore, the enlargement of the functions of government, involved in the task of adjusting to one another the propensity to consume and the inducement to invest, would seem to a nineteenth-century publicist or to a contemporary American financier to be a terrific encroachment on individualism, I defend it, on the contrary, both as the only practicable means of avoiding the destruction of existing economic forms in their entirety and as the condition of the successful functioning of individual initiative. (...) For if effective demand is deficient, not only is the public scandal of wasted resources intolerable, but the individual enterpriser who seeks to bring these resources into action is operating with the odds loaded against him. (...) But if effective demand is adequate, average skill and average good fortune will be enough.

A perspectiva avançada na Teoria Geral revela preocupação com o volume de emprego, enquanto a alocação de recursos e a direção do investimento deveriam ficar a cargo do setor privado. Keynes entende que o sistema descentralizado do capitalismo seria eficiente para alocar o volume existente de emprego, bem como gerar inovações na economia, mas não teria mecanismos automáticos para gerar o nível de demanda agregada para o pleno emprego. O pensamento presente nessa formulação configura base para diversas proposições pós-keynesianas, que entendem a necessidade de ação externa do Estado para não haver recursos desperdiçados na economia em razão da incerteza ${ }^{149}$.

A partir dessas considerações fundamentais de Keynes, mas de pouca indicação prática na Teoria Geral, as políticas pós-keynesianas muitas vezes relacionam amplas possibilidades de ações governamentais. Ainda assim, a utilização de políticas industriais,

\footnotetext{
${ }^{148}$ As flutuações na eficiência marginal do capital podem contrabalançar os efeitos de eventuais mudanças na taxa de juros. Como aventou Keynes (1936, p. 164), "it seems likely that the fluctuations in the market estimation of the marginal efficiency of different types of capital (...) will be too great to be offset by any practicable changes in the rate of interest".

${ }^{149}$ Conforme Carvalho (1997, p. 38), a contradição entre a ação individual, de busca por liquidez diante da incerteza, e a racionalidade social cria a necessidade de intervenção, uma vez que "If uncertainties cannot be eliminated and must be borne by individuals, one cannot expect that solutions emerge spontaneously. Something must be done from the outside of the economy."
} 
principalmente quanto à atuação do capital estatal e estímulos setoriais específicos, parece menos difundida, em especial por receio de mudanças para além do nível dos investimentos, impactando sua alocação. A perspectiva pode ser enriquecida pela consideração das necessidades de alocação mais conducentes ao crescimento, discutidas, por exemplo, pelos estruturalistas. O papel das políticas e dos estímulos devem ser pensados em seu caráter social, especialmente nas políticas fiscais e no planejamento.

\subsubsection{Políticas pós-keynesianas}

O futuro imprevisível não implica que o governo saberá mais do que os agentes privados, no entanto, o governo pode ter visão mais ampla (sem ser voltada ao lucro) sobre as necessidades da comunidade ${ }^{150}$, enquanto agentes privados são motivados por oportunidade de lucro rápido, ressalta Davidson (1991). Dessa forma, o papel do governo é importante na determinação da escala das operações de investimento de longo prazo com benefícios sociais acima das perspectivas de lucro privado. Com efeito, as políticas defendidas em geral pelos pós-keynesianos estão associadas à sustentação da demanda efetiva atual e futura (inclusive para máquinas e equipamentos e aumento da produtividade) por intermédio da política fiscal e da atuação sobre a psicologia empresarial, além da política monetária, da regulação do setor bancário e do provimento de liquide $z^{151}$.

A atuação dos governantes deve ser engenhosa para alcançar os objetivos da sociedade, uma vez que, para a ação efetiva, como afirma Davidson (1991, p. 76), “it is not enough for politicians to be 'right', they must also be 'clever". A identificação dos princípios apropriados para guiar as condutas governamentais não é suficiente, pois o desenho da política "must be cleverly packaged so that it conforms as much as possible with the existing culture, habits and institutional history of the community and hence enlists community support". Nesse contexto, para que a subutilização de recursos

\footnotetext{
${ }^{150}$ Davidson (1991) também identifica a necessidade de o governo limitar ou impedir o que denomina comportamento econômico antissocial. São necessários: a criação de ativos líquidos para aplacar situações de preferência pela liquidez exagerada do setor privado; incentivos financeiros aos empreendedores para investir em projetos socialmente desejáveis, quando se encontram reduzidos os animal spirits; a limitação ao enriquecimento excessivo de indivíduos derivado o poder de mercado quando há desestabilização da distribuição de renda e da inflação; e a geração de ambiente que reprima condutas consideradas, por meio do processo democrático, incivilizadas e ilegais pela comunidade.

${ }^{151} \mathrm{Na}$ opinião de Davidson (1991), o governo tem a possiblidade de eliminar crises sistemáticas de liquidez e corrigir comportamentos econômicos quando a comunidade achar necessário. $\mathrm{O}$ governo pode realizar essas atividades porque não é cerceado pelas restrições contábeis das empresas.
} 
produtivos pelas empresas seja evitada e o bem-estar econômico dos cidadãos seja melhorado, apenas o governo tem a capacidade de estimular demanda efetiva adicional. $\mathrm{O}$ aumento do déficit e da dívida pública deve ser ajustado à escala necessária para as circunstâncias recessivas, assim como a política monetária, considerando que a moeda não é neutra e que essas ações afetam o nível de produto da economia ${ }^{152}$.

A atuação sobre o ambiente institucional também pode ser objeto de intervenção estatal para os pós-keynesianos. Carvalho (1992) destaca que, além de estabelecer sinais claros aos agentes privados para estimulá-los a agir, elevando a segurança e a confiança no futuro, podem ser feitas reformas nas estruturas existentes, como criar redes de proteção social e transformar o ambiente para melhorar a transparência sobre as restrições estruturais que existem sobre a economia e as relações entre os agentes. Nesse sentido, três linhas de intervenção estatal podem ser seguidas, por meio de reformas institucionais para melhorar a eficiência de canais de coordenação entre agentes; alguma forma de planejamento econômico para operação contínua dos mecanismos de coordenação; e uma política integrada para diariamente avaliar e corrigir caminhos quando necessário, em razão de resultados inesperados. O Estado pode tornar explícito aos agentes como o ambiente deve evoluir no futuro relevante. A formulação das políticas deve ser empreendida de maneira sistêmica, com instrumentos de política fiscal e monetária coesos, e deve permitir instituições de coordenação eficientes e estratégias coerentes dos agentes.

Entre os instrumentos de política econômica, Carvalho (1992) destaca políticas fiscais, monetárias e de rendas. A política fiscal deve assegurar a estabilidade do emprego; a política de rendas deve manter a estabilidade dos preços; e a política monetária deve acomodar a demanda por moeda e regular o estado de liquidez. A política fiscal deve regular a demanda agregada, promover redistribuição de renda e organizar as atividades estatais. Para essa política, é reconhecida pelos pós-keynesianos a proposição de Keynes de dois orçamentos para o governo, ressalta Carvalho (1992). O orçamento corrente, relacionado a gastos de custeio e rotineiros, deveria estar sempre balanceado, ao passo

\footnotetext{
152 Davidson (1991, p. 78) entende que o tamanho do déficit necessário para sustentar o pleno emprego tem importância secundária e salienta que: "In this Post Keynesian view, it is of no value for a civilized community to have government maintain a balanced budget while its citizens are impoverished because of a lack of opportunities to earn income. It is if great value to a civilized society to have a government that goes as deeply into debt as necessary to provide the full employment and prosperity of all of its citizens". Cabe notar a distinção frente aos neoclássicos, para quem, pela Lei de Say, a oferta de bens cria sua própria demanda no longo prazo, então o déficit governamental (ou o aumento da oferta monetária) vai implicar demanda adicional acima pleno emprego de longo prazo, gerando inflação.
} 
que o orçamento de capital, dirigido a despesas discricionárias, poderia ser deficitário ou superavitário dependendo do ciclo econômico. Não é o gasto por meio de orçamento deficitário que define uma política keynesiana, mas sim o gasto público e sua capacidade mobilizar o volume de investimento e, principalmente, demonstrar aos agentes que o governo é capaz de intervir para sustentar a demanda.

A falha sistêmica nas economias monetárias, salientada por Carvalho (1997) com base nos trabalhos de Keynes da década de 1930, está relacionada aos problemas nos preços relativos dos ativos ${ }^{153}$ e gera a necessidade da intervenção governamental para mobilizar recursos e influenciar a demanda agregada com visão de longo prazo. Não obstante, Carvalho considera que a responsabilidade direta do Estado por decisões de investimento seria descartada, ao suprimir a iniciativa privada, e tampouco representaria o conteúdo da socialização do investimento. O governo poderia favorecer o investimento privado em determinadas áreas, influenciando a alocação de recursos, inclusive sem descartar experimentos limitados com políticas industriais, mas significando principalmente o fomento da demanda agregada para reduzir incerteza sobre o futuro da economia como um todo. Igualmente, o investimento privado deveria ser estimulado, de modo que os agentes realizariam escolhas mais arriscadas que os distanciariam de ativos mais líquidos, levando ao pleno emprego.

Dessa forma, algumas perspectivas pós-keynesianas atribuem menos importância à necessidade de políticas setoriais. Carvalho (1992) admite mesmo que políticas que influenciam alocação de recursos deveriam, em princípio, ser evitadas, assim como políticas comerciais e industriais direcionadas a mudar a estrutura produtiva não seriam consensuais entre os pós-keynesianos, nem adviriam da teoria propriamente ${ }^{154}$. Embora possa haver essa percepção, as noções de Keynes sobre o investimento podem sugerir diversas formas de intervenção.

\subsubsection{Perspectiva pós-keynesiana no investimento público e nas políticas industriais}

A forma de intervenção estatal, para Keynes, tem relação mais profunda com transformações sociais. Minsky (1975) argumenta que Keynes preocupava-se com a tríade eficiência econômica, justiça social e liberdade individual. O sistema de mercado

${ }^{153}$ Como analisado no capítulo 2, a iliquidez de ativos de capital pode diminuir o ritmo de investimento. 154 As políticas comerciais e industriais, sustenta Carvalho (1992, p. 216), "are, from a theoretical point of view, ad hoc policies to achieve definite goals that are not identified in any particular detail by Post Keynesian foundations." 
descentralizado seria adequado para determinar o que é produzido e de que forma. A justiça social estaria associada a programas que garantem nível de emprego adequado e melhor distribuição de renda e riqueza. A eficiência e a justiça social implicam que a socialização do investimento deve ser combinada com a eliminação da escassez do capital, para garantir distribuição adequada de renda ${ }^{155}$.

Minsky desenvolve interpretação alternativa de Keynes. Existe (ibid., p. 155) uma aparente inconsistência entre a noção de socializar o investimento para o pleno emprego e a visão de que o mercado consegue alocar recursos de maneira que a propriedade e o controle privados podem ser mantidos. Essa inconsistência poderia ser resolvida em parte pela adoção, como era o contexto na década de 1930, de sistemas na prática mistos, com participação do investimento estatal ${ }^{156}$. A interpretação feita do pleno emprego em Keynes no pós-Guerra foi de uma economia com alto lucro e alto investimento conservadora, na qual a política de pleno emprego vinculada a impostos e transferências foi realizada com base no impacto apenas sobre os investimentos privados, induzindo maiores lucros, ao invés de sobre o consumo, a justiça na distribuição de renda ou a utilidade social dos investimentos. O sistema de taxação para induzir o investimento criava viés em favor de setores poupadores e seria, de acordo com Minsky (1975), espécie de "socialism for the rich". A tributação para induzir o investimento pode redistribuir a renda para setores mais poupadores, o que leva a cada vez maiores estímulos na forma de lucros e subsídios ao investimento para garantir o pleno emprego ${ }^{157}$.

Com efeito, algumas interpretações pretendem resgatar elementos das contribuições de Keynes para desenvolver análises alternativas à noção de que as propostas do autor se circunscreveriam ao gasto via orçamento deficitário e a qualquer

\footnotetext{
${ }^{155}$ Como escreve Minsky (1975, p. 146), "Efficiency and justice require that the socialization of investment necessary to assure full employment be combined with the elimination of the scarcity of capital, so as to achieve a marked reduction in income from capital, and direct (income and inheritance) taxation to achieve a proper income distribution".

156 Setores importantes da economia seriam socializados enquanto o resto da economia permaneceria privado. Nas palavras de Minsky (1975, p. 155-56), "Such market or towering-heights socialisms are in principle consistent with Keynes's perspective. These mixed-system resolutions of the problem of economic organization would presumably be consistent with success in achieving the twin goals of approximate full employment and the elimination or radical reduction of private incomes from the ownership of wealth".

${ }^{157}$ Se o investimento não for suficiente para atingir o pleno emprego, então não é adequado induzir maior ritmo de investimento por meio de estímulos ao investimento privado, conforme também pensava Kalecki (1943). Para Minsky (1975, p. 158), “When conservatives are Keynesians, then tax and spending policies may well be used to give life to rentiers rather than to abet their euthanasia". A ideia de trickle-down economics é combatida. Com relação a essa perspectiva alternativa de Minsky, ver também Bellofiore (2014).
} 
forma de estímulo ao setor privado. Conforme Brown-Collier e Collier (1996, p. 344), que analisam diversas contribuições de Keynes a partir da Teoria Geral,

Keynes viewed deficits as the result of a decrease in revenues due to a decrease in economic activity. As such, the best way to avoid deficits was to offset fluctuations in private investment with designed changes in public investment. It was the countercyclical change in public investment that should reduce the size of or the necessity for deficits.

Keynes acreditava que a renda real agregada continuaria a crescer se mais capital fosse acumulado. Esse aumento implica elevação na poupança agregada e crescimento na propensão média a poupar, o que gera vazamento de renda. Esse vazamento requer montante crescente de injeções de renda na forma de investimento para manter nível razoavelmente pleno de emprego e renda. Se não houver investimento, verificar-se-ão desemprego e baixo crescimento. Para atingir níveis crescentes de investimento em capital, é difícil contar apenas com a motivação para o lucro e rendimentos da propriedade do capital, uma vez esses rendimentos devem cair com a menor escassez do capital, além de acentuar as flutuações do investimento privado.

Para Keynes, a solução para essa baixa no investimento seria um programa planejado de investimentos sociais para ser conduzido com base em serviços públicos necessários cuja escala dependeria (sem descartar demanda sociais urgentes) do nível de investimento privado esperado em relação ao nível de pleno emprego das poupanças. $\mathrm{O}$ investimento público poderia preencher o espaço deixado por investimento privado insuficiente e ser direcionado também para compensar as flutuações no investimento privado. Empréstimos para financiar o investimento público seriam justificados na medida em que o capital adquirido provesse retorno real no tempo.

Assim, Brown-Collier e Collier (1996) também entendem que os governos no pósGuerra não utilizaram políticas fiscais de acordo com as concepções de Keynes. Se bem que os governos buscassem maior estabilidade econômica, o objetivo foi a garantia de transferências de renda e o estímulo dos retornos do financiamento e da propriedade do capital privado. A necessidade cada vez maior de investimento privado levou a mais instabilidade econômica e financeira. Assim, a garantia de estabilidade da renda foi cada vez mais difícil de atingir com flutuações acentuadas no investimento privado. Nos EUA, houve a necessidade crescente de transferências de renda e de isenções fiscais e subsídios para sustentar o retorno da propriedade do capital, o que gerou déficits cada vez maiores. 
Os déficits no orçamento corrente ou comum, que não serviriam para amenizar o desemprego, seriam sintoma de investimento privado e público insuficiente.

Considerando o papel do investimento estatal e o caráter social da atuação pública, é possível notar outras proposições de política na obra de Keynes que podem conferir consistência a diversas políticas. As implicações de política econômica de longo prazo na Teoria Geral foram veiculadas com caráter "moderately conservative", possivelmente para que o autor não fosse confundido com um defensor do State Socialism, o qual diminuiria as liberdades individuais e a eficiência e capacidade de inovação da livre iniciativa.

Crotty (1999) observa que, nos anos 1920, Keynes chegou a propor formas radicais de regulação econômica estatal no nível tanto macro quanto microeconômico ${ }^{158}$. Formara-se, na opinião de Keynes, embasamento para investimento público de larga escala como peça central da política de administração de demanda, em consonância com o que chamaria de socialização do investimento na Teoria Geral. A perspectiva de Keynes estava associada também à adoção de políticas industriais para regular empresas e comportamentos setoriais. Para Crotty, não haveria razões para identificar mudanças no pensamento de Keynes para o que foi expresso na Teoria Geral, apenas a forma de introdução dos temas mais radicais teria sido atenuada para a audiência conservadora dos economistas da época.

Crotty (1999) também argumenta que em documentos dos quais Keynes participou em 1928 havia o apoio a conselhos tripartites (governo, empresários e trabalhadores), além de um National Industrial Council, para a concertação de investimentos, a colaboração entre empresas e a sustentação de salários melhores. Ao defender a organização social por meio da representação de grupos nas instâncias decisórias e nas escolhas econômicas de produção, investimento e emprego, gerar-se-ia diminuição dos efeitos negativos da concorrência entre as firmas. A consideração da coordenação entre os agentes e o papel fundamental do Estado seria embrião, para Crotty, da ideia de socialização do investimento.

Keynes (1926) formulou que deveria haver distanciamento dos princípios do Laissez-Faire ao definir "what the State ought to take upon itself to direct by the public wisdom", esboçando espécie de agenda pública. Nem a formação do interesse público nem as ações individuais ilustradas decorrem logicamente do comportamento individual

158 Para Crotty (1999), as características de Keynes identificadas constituiriam atitude corporativista do autor. 
autointeressado. Os interesses privados e sociais não necessariamente coincidem, enquanto não haveria por que acreditar que os indivíduos seriam menos perspicazes atuando em grupos. As ideias "have been directed towards possible improvements in the technique of modern Capitalism by the agency of collective action". Conforme o autor (ibid., p. ):

It is not true that individuals possess a prescriptive "natural liberty" in their economic activities. There is no "compact" conferring perpetual rights on those who Have or on those who Acquire. The world is not so governed from above that private and social interest always coincide. It is not so managed here below that in practice they coincide. It is not a correct deduction from the Principles of Economics that enlightened selfinterest always operates in the public interest. Nor is it true that self-interest generally is enlightened; more often individuals acting separately to promote their own ends are too ignorant or too weak to attain even these. Experience does not show that individuals, when they make up a social unit, are always less clear-sighted than when they act separately.

Algumas formas institucionais são privilegiadas por Keynes, ao serem mais sociais em sua natureza, ainda que não totalmente controladas pelo Estado. Entre elas estão entidades semiautônomas dentro do Estado para atuar de acordo com o interesse público e controles democráticos ${ }^{159}$. Também Keynes considerava as sociedades por ações, que seriam mais interessantes e se aproximariam mais das corporações públicas do que das empresas privadas, pelo fato de a separação entre controle a administração ser quase total e os administradores estarem mais preocupados com estabilidade e reputação do que lucro máximo para os acionistas. A grande empresa tenderia a socializar-se mais, ao conferir menos direitos além do dividendo convencional (ou menos rendas de propriedade do ativo). No entanto, em razão do desenvolvimento do capitalismo contemporâneo, essa forma institucional parece menos propensa a reduzir o rentismo na economia, como visto no capítulo 2 .

Com relação a essas formas institucionais, grandes empreendimentos poderiam ser "semi-socialised", havendo necessidade de flexibilidade e de avaliação das oportunidades da época. Keynes (ibid.)

\footnotetext{
${ }^{159}$ Segundo Keynes (1926): "progress lies in the growth and the recognition of semi-autonomous bodies within the State-bodies whose criterion of action within their own field is solely the public good as they understand it, and from whose deliberations motives of private advantage are excluded, though some place it may still be necessary to leave, until the ambit of men's altruism grows wider, to the separate advantage of particular groups, classes, or faculties-bodies which in the ordinary course of affairs are mainly autonomous within their prescribed limitations, but are subject in the last resort to the sovereignty of the democracy expressed through Parliament".
} 
It is true that many big undertakings, particularly Public Utility enterprises and other business requiring a large fixed capital, still need to be semi-socialised. But we must keep our minds flexible regarding the forms of this semi-socialism. We must take full advantage of the natural tendencies of the day, and we must probably prefer semi-autonomous corporations to organs of the Central Government for which Ministers of State are directly responsible.

A forma institucional semiautônoma, que contrasta com os órgãos do governo central para Keynes, não parece muito distinta da administração indireta ou de empresas com algum controle pelo Estado.

Outro critério da agenda de política pública de Keynes foi a separação de serviços tecnicamente sociais daqueles tecnicamente individuais. As atividades mais importantes da agenda compreenderiam as funções não desempenhadas pelos indivíduos, sendo necessária a atuação do Estado ${ }^{160}$. Entre as políticas práticas encontram-se medidas como o controle da moeda e do crédito por uma instituição central e o recolhimento e disseminação, em grande escala, de informações sobre a situação dos negócios, para lidar com a incerteza e diminuir desigualdades de riqueza e desemprego ${ }^{161}$. Também a preocupação com o volume de poupança na economia (e direcionado ao exterior) e o mercado interno de investimentos na alocação dessas poupanças requereria some "coordinated act of intelligent judgement".

Outros textos de Keynes permitem a identificação de problemas no capitalismo desregulado e a necessidade atuação estatal. A palestra coligida como "Liberalism and Industry", mostra a concepção de Keynes (1927) mais especificamente sobre a política industrial. A livre concorrência mostra custos elevados. Deve ocorrer uma "regulated competition". O governo (1927, p. 643) deve preparar-se para

experiment with all kinds of new sorts of partnership between the state and private enterprise. The solution lies neither with nationalisation nor with unregulated private competition; it lies in a variety of experiments, of attempts to get the best of both worlds.

\footnotetext{
160 Para Keynes (1926), "The important thing for Government is not to do things which individuals are doing already, and to do them a little better or a little worse; but to do those things which at present are not done at all'".

${ }^{161}$ Keynes (1926) admite que "Many of the greatest economic evils of our time are the fruits of risk, uncertainty, and ignorance. It is because particular individuals, fortunate in situation or in abilities, are able to take advantage of uncertainty and ignorance, and also because for the same reason big business is often a lottery, that great inequalities of wealth come about; and these same factors are also the cause of the Unemployment of Labour, or the disappointment of reasonable business expectations, and of the impairment of efficiency and production. Yet the cure lies outside the operations of individuals; it may even be to the interest of individuals to aggravate the disease". As medidas de política para reduzir a incerteza implicariam que a sociedade exerceria "directive intelligence through some appropriate organ of action over many of the inner intricacies of private business, yet it would leave private initiative and enterprise unhindered".
} 
Deve ser reconhecida a existência de oligopólios e de seu encorajamento, por causa das vantagens das firmas maiores, mas também regulação. Também a regulação no mercado de trabalho, como em salários melhores para aumentar a renda nacional, é recomendada.

O caráter estratégico do investimento requer planejamento constante para manter o nível de atividade. Em How to avoid a slump, Keynes (1937b) salienta investimentos em construção, transporte e serviços de utilidade pública, que podem utilizar grandes quantidades de capital. Esses investimentos estão no meio do caminho entre o controle privado e público e precisam de estímulos públicos e baixa taxa de juros. Com essa intenção, necessita-se de um "board of public investment" destinado a preparar projetos viáveis de investimento junto a grandes empresas (públicas e privadas) ${ }^{162}$. As taxas de juros de longo prazo na economia devem ser ajustadas para viabilizar esses investimentos quando necessário. A imaginação construtiva deve ser empreendida para que projetos grandes e úteis possam ser lançados em pouco tempo.

Embora Keynes, na Teoria Geral, entendesse que "It is not the ownership of the instruments of production which it is important for the State to assume", não parece incorreto inferir que, no incentivo ao investimento, formas de ação estatal, sobretudo em mercados monopolistas, na infraestrutura, em insumos básicos e atividades intensivas em capital ou ciência e tecnologia, entre outras, além de instituições financeiras e de pesquisa, podem ser realizadas por meio de empresas públicas ou controladas pelo Estado, como tem sido verificado ao longo da história.

A noção setorial desenvolvida no capítulo 2 também torna relevante a composição da estrutura econômica. Ainda que Keynes (1936, p .379) vislumbrasse "no reason to suppose that the existing system seriously misemploys the factors of production which are in use", pode ser reconsiderada a alocação de recursos em níveis como atividade e setores. Também se pode supor que o direcionamento do emprego de recursos na economia, e não apenas a sustentação do volume do investimento, não seria inconsistente com a posição teórica de Keynes, antes de atingido o nível teórico de pleno emprego ${ }^{163}$.

Nesse contexto, para Pressman (2011), o objetivo principal da política microeconômica dos pós-keynesianos deve ser contribuir com a macroeconomia,

\footnotetext{
${ }^{162}$ De acordo com Keynes (1937b, p. 394), "sound schemes against the time that they are needed. If we wait until the crisis is upon us we shall, of course, be too late. We ought to set up immediately an authority whose business it is not to launch anything at present, but to make sure that detailed plans are prepared". ${ }^{163}$ Cabe considerar também que a determinação do nível de pleno emprego pode não ser definida com exatidão ou ainda talvez seja de difícil medição.
} 
assegurando pleno emprego, distribuição de renda mais igualitária e investimento governamental na ausência do investimento privado. A produtividade, entende Pressman, vai crescer com o aumento da produção, por causa de efeitos de escala.

Os elementos teóricos discutidos com base na perspectiva pós-keynesiana permitem algumas implicações de políticas em economias monetárias de produção. $\mathrm{O}$ investimento privado pode não ser capaz de trazer o pleno emprego na economia, por causa de incerteza e de piora nas expectativas dos empresários.

\subsubsection{Contribuições com base em Marx e Keynes}

Algumas noções essenciais das perspectivas de Marx e Keynes sobre política econômica, em especial no desenvolvimento produtivo, podem ser úteis no debate brasileiro e no entendimento de políticas recentes.

A atuação do Estado na economia é exterior, mas imanente, pois existe separação entre Estado e economia, para os marxistas, embora a intervenção estatal seja necessária sobre a regulação das relações sociais por trás da economia. Essa noção permite entender como existe autonomia relativa do Estado na sociedade. Mesmo que seja factível que o governo mitigue quedas no nível de atividade e no emprego na economia, a capacidade estatal de intervir na economia é limitada para os marxistas.

Formas de pressão sobre a regulação em diversos mercados, entre os quais o de trabalho, podem ser perseguidas pelos trabalhadores de acordo com sua capacidade de articulação. Essa possibilidade é entendida por alguns marxistas com base na noção de autonomia relativa do Estado e permite disputas por melhorias na relação capital-trabalho e para a regulamentação da economia de forma mais justa. Podem ser buscadas coalizões para aumentar o nível de crescimento econômico e de emprego e renda.

A perspectiva de Keynes, a partir de diversos trabalhos, reflete preocupação com o investimento, a distribuição de renda e a coordenação na economia. A ideia de socialização do investimento constitui política de longo prazo fundamental. Keynes, junto com os pós-keynesianos, entende como necessária intervenção estatal para sustentar o pleno emprego. Embora seja comum atribuir a Keynes qualquer política de administração ou sustentação da demanda, o investimento público se torna central quando as expectativas dos empresários não são suficientes para gerar investimento privado, mesmo diante de incentivos continuados. Políticas de demanda com gastos públicos correntes 
poderiam até mitigar os efeitos do desemprego, mas não seriam razoáveis no longo $\operatorname{prazo}^{164}$.

A crítica de Keynes ao laissez-faire, que gera ineficiências quanto a recursos e nível de emprego na economia, implica que diversas formas de coordenação entre setor público e privado podem ser executadas na economia, além de diferentes possibilidades de atuação governamental também na alocação de investimentos. $\mathrm{O}$ investimento e a distribuição de renda tornam-se fundamentais para melhorar a condição econômica nas economias monetárias de produção. Também as formas de intervenção pública podem ser variadas, inclusive na alocação de recursos e institucionalmente.

O debate sobre desenvolvimentismo, realizada na sequência, pode beneficiar-se de diversas contribuições teóricas com base em Marx e Keynes, de maneira complementar à discussão efetuada por Mollo e Amado (2015).

\subsection{Desenvolvimentismo, heterodoxia e políticas industriais no debate brasileiro}

Nesta seção, são comentados posicionamentos diferentes sobre políticas industriais no debate desenvolvimentista no Brasil, que tem vertentes que se utilizam de traços heterodoxos variados. Ao mesmo tempo em que o desenvolvimentismo social pode ser mais adequado à realidade brasileira, os conceitos associados a Marx, Keynes e os estruturalistas latino-americanos identificados por Mollo e Amado (2015) nessa corrente podem ser desenvolvidos quanto à discussão de políticas industriais em perspectiva heterodoxa. São apresentadas quanto às proposições de política industrial as correntes desenvolvimentistas identificadas pelas autoras, principalmente a novodesenvolvimentista de Bresser-Pereira e a social desenvolvimentista, e comentadas contribuições de Marx e Keynes que podem ser utilizadas na perspectiva do social desenvolvimentismo.

\footnotetext{
${ }^{164}$ Keynes (1936, p. 220) lembra que "To dig holes in the ground," paid for out of savings, will increase, not only employment, but the real national dividend of useful goods and services. It is not reasonable, however, that a sensible community should be content to remain dependent on such fortuitous and often wasteful mitigations when once we understand the influences upon which effective demand depends".
} 
Uma avaliação recente de correntes desenvolvimentistas no debate brasileiro abre caminho para entender o quadro teórico das políticas industriais no Brasil. Mollo e Amado (2015) identificam ${ }^{165}$ três correntes de pensamento no debate sobre desenvolvimentismo recente no Brasil, além de observar nessas contribuições influências do estruturalismo cepalino. As autoras identificam o novo desenvolvimentismo precursor, vinculado aos trabalhos de Bresser-Pereira, o novo desenvolvimentismo pós-keynesiano, associado a essa interpretação mais fundamental de Keynes, e o desenvolvimentismo social, este último associado a elementos estruturalistas, pós-keynesianos e marxistas. É possível notar a justificativa desta última corrente com base em elementos teóricos mais adequados à realidade brasileira, ao serem trazidos conceitos de Marx e Keynes e preocupações dos estruturalistas latino-americanos para o desenvolvimento.

Mollo e Amado (2015) destacam retomada no Brasil da discussão do desenvolvimento como estratégia deliberada e não levada a cabo apenas pelas forças do mercado. Enquanto o mainstream entende o crescimento como decorrência de fatores ligados à oferta, como a dotação, alocação e produtividade dos fatores de produção, o desenvolvimentismo apresenta-se como heterodoxia, ao contemplar papel deliberado do Estado para garantir crescimento e transformação da sociedade e apreender os fatores do lado da demanda como os motores do crescimento ${ }^{166}$.

Também a heterodoxia econômica nega em diferentes graus o raciocínio do mercado do fundo de empréstimos e a noção de que é necessária poupança prévia para o investimento, como exposto no capítulo 1. Essa necessidade está vinculada à noção de neutralidade da moeda. O desenvolvimento na ortodoxia está associado a fatores do lado da oferta, acumulados por meio da geração de poupança. A não aceitação dessa perspectiva teórica torna o papel do Estado importante tanto do ponto de vista fiscal como monetário, com diferenças entre as escolas desenvolvimentistas no Brasil.

O estruturalismo cepalino e o novo desenvolvimentismo precursor, notam Mollo e Amado (2015), contêm traços ortodoxos quanto a aspectos monetários, com a consideração implícita da necessidade de poupança prévia para o investimento, ao passo que os desenvolvimentistas sociais e pós-keynesianos não apresentam esses elementos de ortodoxia. Como observado anteriormente, era preocupação do estruturalismo a escassez de poupança nos países periféricos.

\footnotetext{
${ }^{165}$ Ver também Mollo e Amado (2015b).

${ }^{166}$ Sem que sejam desconsiderados fatores do lado da oferta, como inovação e infraestrutura.
} 
O denominado novo desenvolvimentismo precursor tem sido influente no debate brasileiro e se apresenta com traços keynesianos e estruturalistas ${ }^{167}$. Associada aos trabalhos de Bresser-Pereira $(2011,2015)$ e Bresser-Pereira e Gala (2010), essa corrente enfatiza a taxa de câmbio e a poupança interna para o desenvolvimento, contendo significativa preocupação com a poupança do governo. Ao se contraporem a estratégia de crescimento com poupança externa atribuída aos estruturalistas, os novos desenvolvimentistas defendem estratégia de crescimento com poupança interna com base em poupança pública. O maior nível de poupança está associado a crescimento via demanda externa, com o controle sobre câmbio para neutralizar a doença holandesa e a sobreapreciação da moeda, que deve ser mantida em nível chamado de equilíbrio industrial, para estimular os empresários a exportar e investir. A taxa de câmbio é a variável central para a corrente.

Bresser-Pereira e Gala (2010) argumentam que a teoria estruturalista latinoamericana necessitaria de atualização teórica, por causa da industrialização e de nível renda médio que alguns países latino-americanos alcançaram. A proposta central da corrente é a manutenção de alguns elementos estruturalistas clássicos, adaptados ao contexto histórico atual, em combinação com novas teses sobre o desenvolvimento e com a perspectiva keynesiana, esta segundo a qual os principais estrangulamentos ao desenvolvimento se encontram do lado da demanda. A contribuição teórica desses autores poderia ser resumida em oito ideias: (1) a tendência à deterioração dos termos de troca; (2) papel central do Estado no desenvolvimento; (3) caráter estrutural do desenvolvimento; (4) subdesenvolvimento não como um estágio atrasado de desenvolvimento; (5) existência de oferta ilimitada de mão de obra; (6) tese da indústria infante; (7) tese da inflação estrutural; e (8) crescimento com poupança externa.

A essas oito teses Bresser-Pereira e Gala (ibid.) adicionam cinco novas proposições, que formam o corpo teórico da Macroeconomia estruturalista do desenvolvimento: (9) manutenção de taxa de câmbio competitiva; (10) tendência à sobrevalorização cíclica da taxa de câmbio; (11) existência de doença holandesa; (12) crítica ao déficit em conta corrente; (13) manutenção de equilíbrio fiscal. As proposições (10), (11) e (12) relacionam-se, na opinião dos autores, principalmente, ao câmbio, seja

${ }^{167}$ Para Bresser-Pereira (2011), haveria indicações do surgimento no Brasil de nova escola de pensamento econômico, uma Escola Keynesiano-estruturalista do Desenvolvimento, que tem como fundamento teórico uma Macroeconomia Estruturalista do Desenvolvimento e como proposta de política econômica ou, mais amplamente, como estratégia nacional de desenvolvimento, o Novo Desenvolvimentismo. 
pela política cambial, por tendências cíclicas, pelo impacto de externalidades ou pela sensibilidade da economia a esta variável. Entre as cinco teses adicionais, apenas a tese 13 não está relacionada diretamente com a taxa de câmbio. No caso dos países que alcançaram patamar de renda médio, as proposições (6), (7) e (8) podem ser abandonadas, ao passo que aquela de número (2) deve ser modificada. O caso da indústria infante está diretamente relacionado à perspectiva de política industrial para substituição de importações. Os autores avaliam que, em países de renda média, o argumento não se sustenta, sendo necessária política industrial estratégica para apoiar empresas que mostrem condições de serem competitivas, mas que precisariam de apoio momentâneo do Estado. Já a proposição acerca do Estado deveria ser modificada, para que o conteúdo apresentasse mudança de atuação, buscando-se caráter estratégico ao Estado, como indutor do desenvolvimento econômico.

$\mathrm{Na}$ estratégia do novo-desenvolvimento, a ideia de industrialização orientada pelo Estado e baseada na substituição de importações seria permutada pela industrialização orientada para as exportações ${ }^{168}$, sem protecionismo. A política industrial, ao invés de central na atuação do governo, seria considerada de maneira subsidiária, mas tendo caráter estratégico. Bresser-Pereira e Gala (2010) admitem que um critério de eficiência, no caso da estratégia exportadora, seria beneficiar pela política industrial apenas as empresas eficientes o suficiente para exportar. No caso da mudança estrutural, a nova corrente entende esse processo como de inovação nos setores já explorados e de transferência de mão de obra para setores com valor adicionado per capita e salários médios cada vez mais elevados.

Apesar da menção à política industrial, os novos-desenvolvimentistas estão mais preocupados com a relação macroeconômica da taxa de câmbio. Falta a essa corrente o tratamento das mudanças estruturais defendidas pelos estruturalistas originários, que permitiriam sair da heterogeneidade estrutural e da dependência tecnológica, além da preocupação com a distribuição de renda. As medidas de controle da taxa de câmbio, que deveria atingir nível de "equilíbrio industrial", poderiam aprofundar os dois problemas estruturais, já que o estímulo do câmbio sobre a rentabilidade das firmas deve beneficiar também setores mais básicos.

168 Os argumentos de Bresser e Gala (2010), no que diz respeito à política industrial, são dirigidos principalmente à perspectiva de substituição de importações da CEPAL, que estaria superada, enquanto a industrialização orientada para as exportações seria mais desejável para os países de renda média. Assim, o novo-desenvolvimentismo não seria protecionista. 
Conforme Mollo e Amado (2015), não existe qualquer garantia de que determinado nível do câmbio será suficiente para reverter ou realinhar a estrutura do comércio exterior da periferia a uma estrutura funcional ao crescimento, ou seja, com uma estrutura de elasticidades de exportação e importação que permita a superação dos entraves impostos pelo comércio exterior ao crescimento. Os salários, na visão novodesenvolvimentista, devem aumentar apenas em linha com a produtividade e devem ser contidos para elevar a competitividade internacional das empresas brasileiras ${ }^{169}$. Os limites impostos pelas exportações são consequência dos problemas estruturais característicos do subdesenvolvimento, como a heterogeneidade estrutural e a dependência tecnológica. Na proposta novo-desenvolvimentista, nenhum desses dois problemas é abordado. O foco no setor exportador pode aprofundar os dois problemas, uma vez que não existe nenhuma garantia de que o tipo de medida adotada será suficiente para reverter ou realinhar a estrutura do comércio exterior da periferia a uma estrutura funcional ao crescimento, com estrutura de elasticidades de exportação e importação que permitam a superação dos entraves impostos pelo comércio exterior ao crescimento.

Já os desenvolvimentistas pós-keynesianos encontram-se próximos do novodesenvolvimentismo quanto ao foco no mercado externo, no entanto, não estão associados a elementos teóricos ortodoxos, destacam Mollo e Amado (2015). Não há preocupação com poupança prévia, ainda que seja fundamental ter mecanismos institucionais que garantam a consolidação financeira, ou seja, o direcionamento da poupança para o financiamento de longo prazo. A preferência pela liquidez dos poupadores vai ser elemento importante, porque pode inibir a demanda efetiva ao reduzir o investimento. A taxa de juros será a variável chave, enquanto preveem a necessidade de intervenção do Estado para quebrar círculos viciosos reais e monetários que limitam o desenvolvimento de economias periféricas.

Os social-desenvolvimentistas ressaltam o crescimento baseado no mercado interno e as políticas de distribuição de renda, tendo como variável chave o consumo de massas. Essa corrente, de acordo com Mollo e Amado (2015), está próxima da abordagem marxista, pela possibilidade de melhoria na inserção dos trabalhadores na relação capital-

\footnotetext{
${ }^{169}$ Uma formulação recente do novo-desenvolvimentismo se encontra em Bresser-Pereira (2015), em que são comentadas críticas, como a do modelo exportador e a questão social. Há maior exportação com o crescimento da taxa de câmbio, depois deve ocorrer estabilidade do coeficiente de exportação na economia. A desigualdade deve ser combatida, pela política tributária, de juros e do aumento do gasto com serviços públicos. Ainda assim, é possível notar que a desvalorização do câmbio vai implicar queda nos salários reais.
} 
trabalho. Nesse sentido, Bielschowsky (2012) apresenta estratégia de desenvolvimento que se apoia em três motores de crescimento $^{170}$ : amplo mercado interno, demanda nacional e mundial por recursos naturais e demanda estatal e privada por investimentos em infraestrutura econômica e social. Essas fontes de demanda podem ser potencializadas por inovações tecnológicas e pela recuperação de encadeamentos produtivos fragilizados, permitindo transformação estrutural, aumento de escala e desenvolvimento a longo prazo da economia brasileira. A expansão do consumo aumenta investimentos, que permitem elevação da produtividade e aumento de salários, o que agrega, com melhora na distribuição de renda, mais rendimentos em consumo popular. Para os socialdesenvolvimentistas, requer-se cautela com taxas de câmbio desvalorizadas, por causa dos efeitos de redução nos salários.

Ao invés da oposição entre modelos wage-led e profit-led, entre os desenvolvimentistas, Mollo e Amado (2015) notam, com base em Dos Santos (2013), que o ciclo de reprodução do capital em Marx pode ser pensado na oposição entre regimes investment-led e consumption-led. Como salários e lucros são determinados em momentos distintos do ciclo, a distribuição de renda é definida dependendo dos adiantamentos de capital feitos no início do ciclo. Se houver maior gasto dos capitalistas com a ampliação do capital e venda correspondente, será despendido maior montante de dinheiro em capital variável. Dessa forma, o investimento maior representará mais emprego e pagamento de salários.

Podem ser verificadas diversas vantagens do regime de crescimento associado ao social-desenvolvimentismo. A discussão de Mollo e Amado (2015) revela o impacto do investimento e da indústria. A estratégia é melhor do ponto de vista da justiça social. Utiliza-se a demanda interna, com preocupação com a indústria, encadeamentos produtivos e efeitos sobre setores de alta tecnologia e tradicionais. Pelo ciclo de reprodução do capital, o aumento dos investimentos pode elevar endogenamente a massa de salários. Melhorias no salário via transferências governamentais podem gerar crescimento (exógeno) nos salários. A retomada dos investimentos deve priorizar o setor industrial, que pode beneficiar-se com a elevação da demanda interna.

Além dos elementos teóricos discutidos por Mollo e Amado (2015), podem ser trazidas noções de Marx e Keynes que complementam a classificação das autoras e

\footnotetext{
${ }^{170}$ A demanda externa é propositalmente excluída, pois, de acordo com Bielschowsky (2002), as decisões de investir nas empresas industriais sediadas nos países acontecem essencialmente em função do mercado interno e só de forma complementar objetivam o mercado internacional.
} 
permitem notar outros pontos de convergência entre os desenvolvimentistas. A relação complexa do papel do Estado na economia e na política, como se nota na tradição marxista, torna necessário entender a possibilidade de organização coletiva dos trabalhadores para pressionar pelo desenvolvimento econômico e social. A possibilidade de políticas de desenvolvimento produtivo ou industriais na tradição pós-keynesiana em conjunto com a preocupação com a distribuição de renda e o consumo, discutida na seção 3.4.2, pode estabelecer ponto de contato maior entre os autores brasileiros póskeynesianos e os desenvolvimentistas sociais.

Também a noção de que podem ser tentadas coalizões políticas para o desenvolvimento econômico e social pode ser importante para a organização prática frente ao Estado. Bresser-Pereira (2015), por exemplo, defende coalização desenvolvimentista frente ao liberalismo rentista atual. Alguns pontos de convergência para uma pauta desenvolvimentista comum podem estar no desenvolvimento por meio da expansão industrial e da demanda interna, com inclusão social.

\subsection{Comentários finais}

Ainda que exista preocupação maior da economia mainstream na diversificação produtiva e na mudança estrutural, as contribuições teóricas ainda estão fundadas em hipóteses restritivas do comportamento econômico e partem teoricamente da intervenção estatal como uma exceção ao mecanismo de mercado. A identificação de falhas de mercado frente a mercado perfeito justifica a atuação governamental, por mais pervasivas que sejam essas falhas e ainda que sejam entendidas como políticas second best.

Medidas de eficiência ou atuação com base em correção de falhas de mercados ou externalidades, associadas à perspectiva mainstream, podem não conduzir a melhores resultados para a sociedade. Apesar do discurso atual em que são propostas ações denominadas de políticas industriais, coordenação de investimentos ou redução na incerteza, a visão recente da ortodoxia, como no rejuvenescimento da política industrial ou na nova economia estrutural, não parece fugir aos fundamentos estabelecidos na teoria neoclássica padrão e seus corolários. 
As preocupações com o processo de geração de valor, no mercado interno ou nas relações com outras economias, as estratégias diante da incerteza e do cálculo do investimento e o reconhecimento da evolução histórica da estrutura produtiva devem ser determinantes para a formulação de políticas. A aceitação de outros fundamentos para a formulação teórica permite entender a atuação governamental como agente fundamental sobre a estrutura econômica, sem que haja o suposto de que haverá ineficiência inerente às ações estatais.

A evolução das ideias cepalinas ou do estruturalismo latino-americano indica as dificuldades associadas à desigualdade na economia mundial e à estrutura produtiva heterogênea das economias periféricas, assim como a necessidade de os governos agirem para quebrar ciclo de subdesenvolvimento econômico e social de acordo com objetivos sociais. Existe convergência entre neoestrutralismo e a escola schumpeteriana ou evolucionária que traz noções importantes para a atuação governamental na mudança estrutural, em especial quanto ao papel da inovação.

A preocupação com o desenvolvimento econômico em bases diferenciadas e em perspectiva histórica pode mostrar-se mais adequada para entender desafios ao desenvolvimento produtivo brasileiro. As perspectivas que parecem destacar-se recentemente admitem a necessidade da atuação empreendedora do Estado, para além de políticas de administração de demanda e políticas de incentivo na inovação, são importantes. O Estado pode atuar como um criador de mercados e modificador de estruturas econômicas.

O papel do Estado adquire relevo na discussão realizada. Conquanto tenha limitações definidas pela instabilidade e a propensão a crises no capitalismo, existem formas de atuação governamental que podem intervir no desenvolvimento econômico e social, em aspectos variados como a diversificação produtiva e o nível de emprego, salários e investimento. As contribuições de Marx e Keynes podem somar-se à literatura existente sobre políticas de desenvolvimento produtivo e servir de base para o debate brasileiro.

A intervenção estatal decorrente da visão de Marx está associada à complexidade do capitalismo e à autonomia relativa do Estado. O Estado tem campo de atuação significativo na economia, embora não possa afastar a possibilidade de crises ou suplantar o mercado privado. Existe autonomia relativa que permite a possibilidade de pressões por melhorias na relação capital-trabalho e na regulamentação econômica. 
As políticas keynesianas como têm sido apresentadas em geral podem ser representantes restritas da visão de Keynes sobre a atuação estatal. A distribuição de renda e a forma de intervenção, que implica estímulos ao setor privado até o momento em que houver aumento do investimento das empresas, podem ser interpretadas como centrais na perspectiva de Keynes de políticas de longo prazo, como a socialização do investimento. Diversas políticas podem ser derivadas da concepção de Keynes, entre as quais a necessidade do investimento público em formas variadas, como no direcionamento dos recursos na economia.

Os problemas da economia capitalista podem ser entendidos de maneira mais aprofundada pelas considerações de Marx e Keynes. A crítica ao caráter instável da economia e à desigualdade provocada pelo mecanismo de mercado são pontos que trazem justificativa para disputas sobre o papel do Estado. Ao invés de construir a justificativa por meio da pesquisa de determinadas falhas de mercado na economia, parte-se de sistema inerentemente defectível. Os supostos são mais próximos à realidade e permitem entender as diversas formas históricas de atuação estatal, que não se conformam a mitigar as chamadas imperfeições, mas sim a exercer ação empreendedora e geral sobre a sustentação do sistema. Ainda assim, cabe notar que existem limites à ação estatal, em especial nas crises, mas também no estímulo ao investimento privado.

A discussão sobre as correntes de desenvolvimentismo no Brasil tem considerações teóricas e de política econômica importantes, a partir de classificação feita entre as correntes heterodoxas. São discutidos o novo-desenvolvimentismo, o novodesenvolvimentismo pós-keynesiano e o social desenvolvimentismo, que mostra perspectivas mais apropriadas ao desenvolvimento no Brasil. Outras noções de Marx e Keynes podem ser trazidas ao debate.

As perspectivas heterodoxas possibilitam justificativa teórica ampla para a ação governamental. Se houver preocupação com o pleno emprego e condições melhores no processo de trabalho, o investimento e a acumulação parecem constituir objetivo de política de desenvolvimento produtivo mais apropriado ao desenvolvimento econômico e social para a caso brasileiro. A relevância outorgada à indústria e setores líderes na acumulação de capital e de competências na economia parece vinculada a esta perspectiva, que está próxima ao social-desenvolvimentismo. 


\section{Capítulo 4. Economia brasileira recente e políticas de desenvolvimento produtivo}

\subsection{Introdução}

O debate heterodoxo sobre desenvolvimento está relacionado com o desempenho e as condições da estrutura produtiva brasileira. A forma de inserção das economias na produção mundial é determinante para o desenvolvimento econômico, assim como se torna fundamental entender aspectos da estrutura interna e da atuação das firmas na economia.

No contexto da inserção internacional da economia brasileira, alguns indicadores podem sinalizar o desempenho brasileiro diferenciado em anos recentes. $\mathrm{O}$ valor gerado na indústria mundial indica elementos da participação na economia mundial. A posição brasileira parece mostrar piora relativa na geração de valor na indústria mundial, ao mesmo tempo em que apresenta indicadores menos favoráveis comparativamente quanto à composição interna de manufaturados de média e alta tecnologia e da pauta de exportações. A evolução recente do comércio exterior brasileiro revela desempenho que pode ser prejudicial quanto à vulnerabilidade externa e quanto ao dinamismo produtivo da economia.

O desenvolvimento recente da economia brasileira está associado a certas mudanças estruturais. As mudanças na estrutura produtiva recente, com menor parcela no valor adicionado da indústria, podem implicar problemas no desenvolvimento interno na economia brasileira. A indústria de transformação tem apresentado dificuldades para gerar valor e parece substituir produção interna por importada.

Além desta introdução, o presente capítulo está dividido em mais quatro seções. São discutidos elementos da inserção internacional da economia brasileira e da estrutura produtiva interna, respectivamente, nas seções 4.1 e 4.2, em seguida às quais, na seção 4.3, são discutidos alguns elementos para as políticas industriais no Brasil. 


\subsection{Aspectos da inserção da economia brasileira na economia mundial}

\subsubsection{Introdução}

$\mathrm{Na}$ presente seção, almeja-se apresentar aspectos significativos da inserção da economia brasileira na economia mundial com respeito ao desenvolvimento produtivo recente. Algumas informações relativas à indústria, ao saldo do comércio exterior e à composição da balança comercial são discutidas.

A participação brasileira na indústria mundial mostra piora no desempenho recente. Aspectos comparativos quanto à composição da estrutura interna e das exportações permitem qualificar elementos da inserção brasileira na indústria de transformação.

O desempenho da balança comercial pode ser considerado preocupante, em razão do aumento da vulnerabilidade externa associada a essa evolução. Igualmente, a composição setorial da pauta comercial pode ser determinante para o desempenho produtivo no longo prazo, inclusive quanto ao conteúdo tecnológico.

\subsubsection{Aspectos da indústria na economia mundial recente}

O estudo da indústria mundial deve permitir avaliação da importância relativa da indústria brasileira e de alguns desafios relacionados ao setor comparativamente. De acordo com a UNIDO (2013), os países mais desenvolvidos têm perdido participação para os menos desenvolvidos desde 1992, no entanto, a expansão dos países menos desenvolvidos tem sido muito concentrada.

Observa-se, de acordo a UNIDO (ibid., p. 170), tendência recente de aumento da participação do valor adicionado da indústria de transformação no PIB mundial em conjunto com mudança gradual da produção dos países industrializados em direção a países em processo de industrialização.

Since the start of this century industrializing economies have accounted for a growing share of the world's manufacturing value added (MVA). This trend is as much the result of a gradual shift of production from industrialized to industrializing countries to benefit from cheaper labour, largely improved infrastructure and lower social costs, as it is a 
reflection of the growth of industrializing countries' domestic markets for industrial goods due to higher incomes and a fast-rising middle class.

Não obstante essa trajetória, a expansão dos países menos desenvolvidos tem sido muito concentrada, com destaque positivo para a China e certa perda para Brasil e México.

Com base nas séries de valor adicionado na manufatura desenvolvidas pela UNIDO (2015), pode ser evidenciada a evolução das economias comparativamente no período 1990-2013, considerando um total de 205 economias (sendo 187 para estimativas dos anos 2012 e 2013). O valor mundial quase dobrou, passando de US\$4.872 bilhões para US\$ 8.980 bilhões entre 1990 e 2013, em dólares constantes de 2005, ainda que tenha ocorrido queda em 2008 (-0,5\%) e 2009 (-8,1\%). A trajetória da participação dos grupos de países no total mundial do valor adicionado na manufatura mostrou ganhos para os países em desenvolvimento e economias emergentes em industrialização (industrializing emerging economies), os quais partiram de $17,5 \%$ para $35,5 \%$ do total mundial, em detrimento dos países industrializados (e de maior renda), que caíram de $82,5 \%$ para $64,5 \%$ desse total.

A ascensão das economias em desenvolvimento foi acelerada a partir da década de 2000, período no qual houve expansão média de 8,2\%, de 2001 a 2013, ao passo que havia sido registrada elevação média de 5,1\% de 1990 a 2000. Apesar da expansão dos países em desenvolvimento desde 1990, esse crescimento adveio quase que totalmente da China, que ganhou 14,9 pontos percentuais de participação mundial (atingindo 17,6\% do total), como observado no gráfico 1. Entre as economias em desenvolvimento, houve ainda alguns ganhos no Sul (1,6\%) e no Sudeste da Ásia (1,4\%), mas perdas na América Latina (-0,9\%) e estabilidade na África.

Gráfico 1. Participação de grupos de economias e da China no total mundial do valor adicionado na manufatura, 1990-2013. 


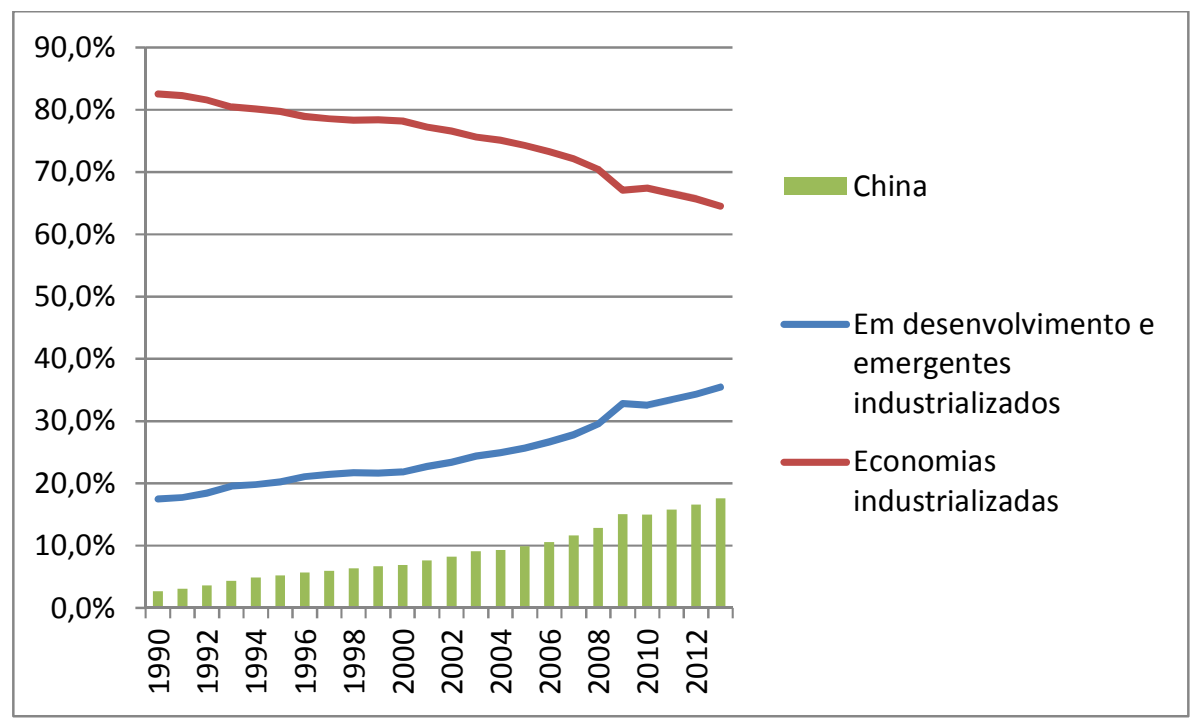

Fonte: UNIDO (2015). Elaboração própria.

Considerando economias individuais, as participações ao longo do tempo evidenciam desempenhos diferenciados, ainda que a ordem e o posicionamento individuais não tenham sido fundamentalmente alterados, exceto pelo caso da China ${ }^{171}$. No caso do Brasil, a participação da economia no valor adicionado na manufatura passou de $2,2 \%$ para $1,7 \%$ do total mundial, em trajetória de queda gradual, mesmo que o posicionamento relativo do país não tenha variado muito, de $11^{\circ}$ para $12^{\circ}$.

O contexto brasileiro parece ser de certa estagnação ou piora na participação no valor adicionado na manufatura mundial, enquanto economias relativamente próximas como Coreia do Sul, Índia e Taiwan tiveram desempenho melhor. Embora a geração de valor, em dólares constantes de 2005, tenha aumento no Brasil, a comparação internacional mostra situação menos favorável desde 1990, conforme se observa nos gráficos 2 e 3 abaixo.

Gráfico 2. Valor adicionado na manufatura e participação no valor adicionado na manufatura mundial, países selecionados, 1990-2013.

${ }^{171}$ Nota-se elevada correlação entre todos os países da série ou entre as 25 maiores economias. 


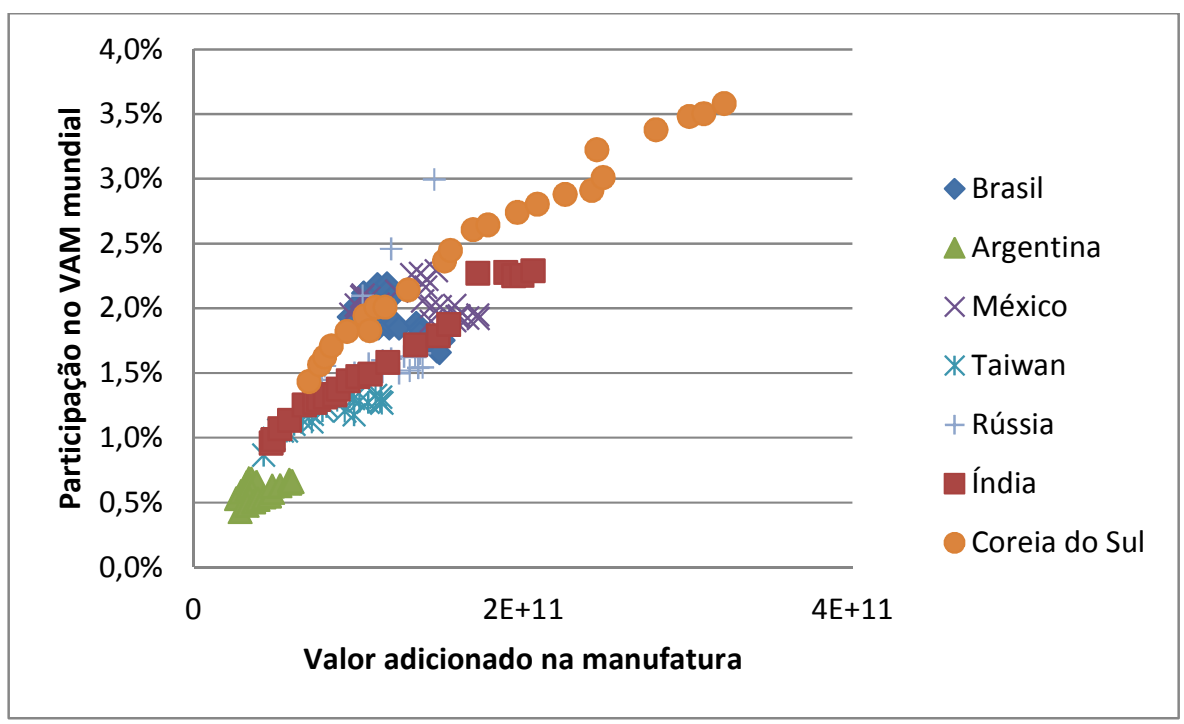

Fonte: UNIDO (2015). Elaboração própria.

Gráfico 3. Valor adicionado na manufatura e participação no valor adicionado na manufatura, economia brasileira, 1990-2013.

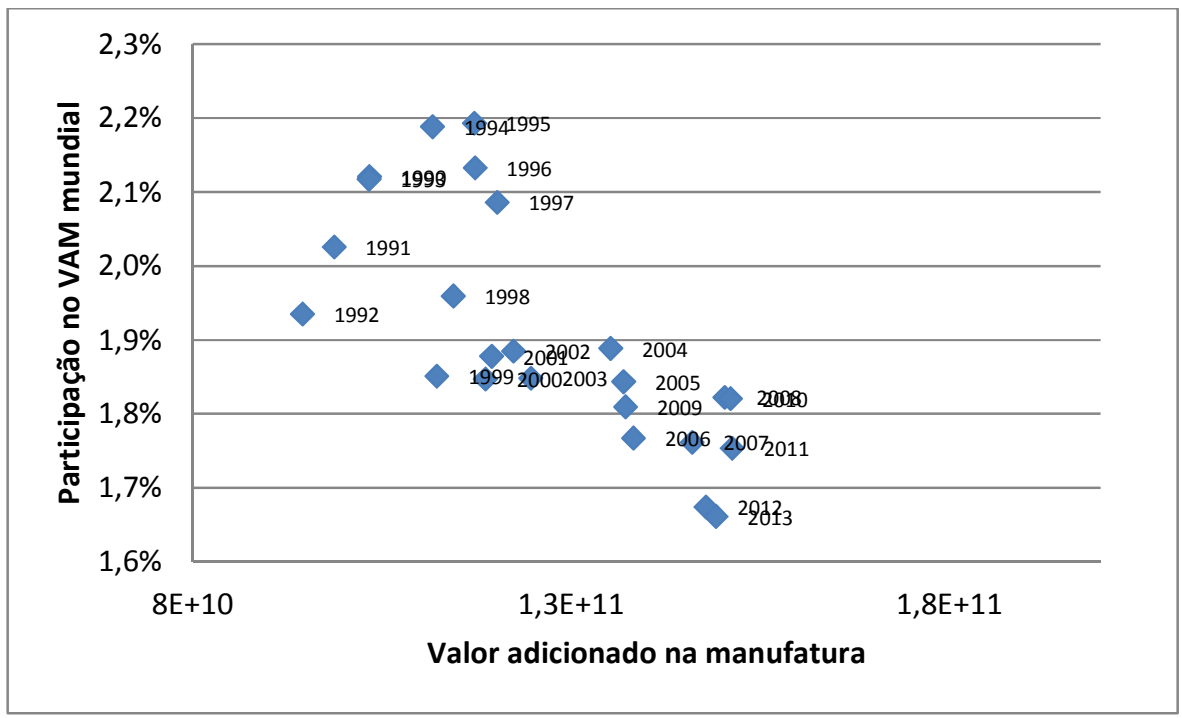

Fonte: UNIDO (2015). Elaboração própria.

A composição da indústria de transformação segundo o perfil tecnológico é bastante diferenciada. Pelos dados da UNIDO (2015), enquanto economias como China, México e Coreia do Sul melhoraram a participação das exportações de manufaturados no total e dos manufaturados de média e alta tecnologia nas exportações manufatureiras, bem como a composição dos segmentos de média e alta tecnologia na produção interna, o Brasil apresentou piora ou certa estabilidade nesses indicadores entre 1990 e 2012, como 
se nota na tabela 1 abaixo. A economia brasileira apresentava participação significativa dos segmentos de média e alta tecnologia na produção manufatureira em 1990 (49,4\%), mas sofreu forte queda ao longo da década de 1990 (atingindo 34,7\% em 2002). Houve certa recuperação na década de 2000, para nível (37,2\%) abaixo do registrado em 1990.

Tabela 1. Participação de segmentos de média e alta tecnologia no PIB industrial e nas exportações industriais e das exportações industriais nas exportações totais, 1990,

2002 e 2012.

\begin{tabular}{|c|c|c|c|c|c|c|c|c|c|}
\hline & \multicolumn{3}{|c|}{$\begin{array}{l}\text { Participação dos } \\
\text { segmentos de média e } \\
\text { alta tecnologia na } \\
\text { produção manufatureira }\end{array}$} & \multicolumn{3}{|c|}{$\begin{array}{l}\text { Participação das } \\
\text { exportações de média e } \\
\text { alta tecnologia nas } \\
\text { exportações } \\
\text { manufatureiras totais }\end{array}$} & \multicolumn{3}{|c|}{$\begin{array}{l}\text { Participação das } \\
\text { exportações } \\
\text { manufatureiras nas } \\
\text { exportações totais }\end{array}$} \\
\hline & 1990 & 2002 & 2012 & 1990 & 2002 & 2012 & 1990 & 2002 & 2012 \\
\hline Argentina & $24,9 \%$ & $25,8 \%$ & $26,8 \%$ & $23,6 \%$ & $31,7 \%$ & $47,2 \%$ & $49,0 \%$ & $53,2 \%$ & $50,2 \%$ \\
\hline Brazil & $49,4 \%$ & $34,7 \%$ & $37,2 \%$ & $37,9 \%$ & $46,1 \%$ & $38,5 \%$ & $74,4 \%$ & $71,5 \%$ & $62,2 \%$ \\
\hline Chile & $15,1 \%$ & $16,2 \%$ & $16,2 \%$ & $10,8 \%$ & $14,7 \%$ & $12,1 \%$ & $31,7 \%$ & $46,7 \%$ & $49,5 \%$ \\
\hline China & $37,8 \%$ & $43,9 \%$ & $41,4 \%$ & $28,4 \%$ & $50,0 \%$ & $58,4 \%$ & $84,0 \%$ & $93,0 \%$ & $96,6 \%$ \\
\hline Colombia & $24,3 \%$ & $21,9 \%$ & $20,9 \%$ & $24,2 \%$ & $38,8 \%$ & $34,2 \%$ & $38,0 \%$ & $48,4 \%$ & $27,5 \%$ \\
\hline France & $51,7 \%$ & $44,8 \%$ & $47,1 \%$ & $59,4 \%$ & $67,4 \%$ & $65,0 \%$ & $86,0 \%$ & $89,2 \%$ & $87,7 \%$ \\
\hline Germany & $48,0 \%$ & $55,1 \%$ & $60,1 \%$ & $68,9 \%$ & $73,0 \%$ & $72,5 \%$ & $91,1 \%$ & $91,3 \%$ & $87,6 \%$ \\
\hline India & $40,0 \%$ & $39,3 \%$ & $38,7 \%$ & $18,1 \%$ & $21,5 \%$ & $28,0 \%$ & $78,3 \%$ & $83,4 \%$ & $84,1 \%$ \\
\hline Indonesia & $20,8 \%$ & $27,3 \%$ & $37,9 \%$ & $12,2 \%$ & $33,8 \%$ & $30,7 \%$ & $47,6 \%$ & $68,7 \%$ & $57,8 \%$ \\
\hline Mexico & $42,1 \%$ & $42,6 \%$ & $37,0 \%$ & $61,2 \%$ & $75,8 \%$ & $78,6 \%$ & $51,2 \%$ & $87,3 \%$ & $78,3 \%$ \\
\hline Philippines & $24,5 \%$ & $41,1 \%$ & $41,7 \%$ & $38,5 \%$ & $82,6 \%$ & $73,1 \%$ & $86,9 \%$ & $95,9 \%$ & $91,0 \%$ \\
\hline Republic of Korea & $41,6 \%$ & $53,4 \%$ & $60,1 \%$ & $51,1 \%$ & $73,3 \%$ & $70,6 \%$ & $95,8 \%$ & $97,1 \%$ & $96,8 \%$ \\
\hline Russian Federation & $14,5 \%$ & $23,0 \%$ & $28,1 \%$ & $37,6 \%$ & $36,7 \%$ & $23,7 \%$ & $39,6 \%$ & $38,4 \%$ & $40,3 \%$ \\
\hline Thailand & $20,9 \%$ & $42,0 \%$ & $46,3 \%$ & $42,3 \%$ & $70,3 \%$ & $71,3 \%$ & $75,0 \%$ & $84,7 \%$ & $85,9 \%$ \\
\hline United Kingdom & $44,8 \%$ & $41,3 \%$ & $46,9 \%$ & $65,9 \%$ & $70,0 \%$ & $63,0 \%$ & $84,1 \%$ & $82,2 \%$ & $76,4 \%$ \\
\hline United States of America & $48,7 \%$ & $49,1 \%$ & $50,6 \%$ & $72,5 \%$ & $75,0 \%$ & $62,5 \%$ & $81,6 \%$ & $86,5 \%$ & $75,7 \%$ \\
\hline Venezuela & $14,5 \%$ & $34,3 \%$ & $34,3 \%$ & $32,4 \%$ & $39,6 \%$ & $4,3 \%$ & $13,1 \%$ & $17,8 \%$ & $32,8 \%$ \\
\hline
\end{tabular}

Fonte: UNIDO (2015). Elaboração própria.

As formas de inserção na produção mundial contemporânea podem ser variadas e estão associadas às cadeias de valor de determinados produtos ou atividades ${ }^{172}$. Para a UNIDO (2013b), a decomposição das atividades produtivas tem sido marcante, ao realinhar geográfica e organizacionalmente as operações da indústria pela estratégia e

\footnotetext{
172 A discussão sobre cadeias globais de valor ou de mercadorias tem sido crescente. Uma significativa exposição pioneira sobre o tema tinha como referência autores associados à perspectiva de sistemas-mundo (ver Gereffi e Korzeniewicz, 1993). Recentemente, diversos estudos apresentam como base analítica cadeias globais, como, por exemplo, Sturgeon e Memedovic (2011).
} 
P\&D, recorrendo-se a outsourcing e offshoring. São desenvolvidas cadeias de fornecedores nas quais determinados elos são mais centrais e geram mais valor ou rendimentos. Torna-se necessário desenvolver localmente competências para se ter inserção qualificada nessas cadeias ${ }^{173}$.

Laplane (2015) entende que a estrutura industrial sofreu mudança desde a década de 1990, em razão de mudanças nos regimes nacionais de política econômica e dos regimes internacionais de comércio e investimento. O neoliberalismo implicou estrutura globalizada (por causa da segmentação da produção e montagem), concentrada (resultante da consolidação por fusões e aquisições, criando até monopólios e duopólios que comandam diversas cadeias globais de valor) e fortemente desequilibrada quanto à localização da produção e do consumo no mundo. A concorrência entre empresas e países foi acirrada e esteve associada a novos produtos inovadores, automação de processos, segmentação de mercado por diferenciação, encurtamento do ciclo de vida dos produtos, redução de salários reais e direitos trabalhistas, diminuição do custo de insumos e de logística pela subcontratação, maior flexibilidade regulatória e de incentivos fiscais de governos locais e nacionais.

Novos modelos de desenvolvimento industrial após a crise de 2008-2009 podem estar associados a novas bases tecnológicas e científicas e às estratégias de governos e firmas. Como notado no capítulo 3, existe movimento de reindustrialização nos países mais ricos. As economias asiáticas, que ganharam participação na indústria global, não devem deixar de intervir para alcançar maior competitividade e novos mercados, como destacado por Laplane (2015).

De acordo com a consultoria Mckinsey (2013), deve ser rentável a exploração de tecnologias disruptivas como internet móvel e internet das coisas (internet of things), tecnologia em nuvem (cloud technology) automação do conhecimento, robótica avançada

\footnotetext{
${ }^{173}$ Os fluxos de valor adicionado indicariam a fonte de criação de empregos e dos benefícios do comércio para as economias envolvidas na cadeia de valor, o que serviria também para explicar competitividade e interdependência entre as nações. A fragmentação da produção que é verificada na economia mundial, em que bens e serviços fazem parte de cadeias de valor globais, significa que a compilação estatística tradicional do comércio internacional bruto pode ser reconsiderada. $\mathrm{O}$ conteúdo de valor adicionado tem caído com o tempo. A OMC e a OCDE (2012) propõem que os componentes dos fluxos de comércio podem ser decompostos naqueles de valor adicionado interno e nos de importações. A economia brasileira encontra-se entre as maiores geradoras de valor adicionado nas exportações, sendo a $3^{\mathrm{a}} \mathrm{em} 2009$, embora tenha diferenças setoriais significativas. A principal razão para esse posicionamento é a forte geração de valor em produtos básicos, que não utilizam muitos insumos importados. A situação brasileira seria benéfica para o desenvolvimento, no entanto, esse posicionamento deve ser qualificado a partir da consideração das tendências recentes na composição da pauta comercial brasileira e da estrutura econômica interna.
} 
(para automação de tarefas ou auxílio a humanos), veículos autônomos, genômica de nova geração (next-generation genomics), manufatura aditiva (impressoras 3D), armazenamento de energia, materiais avançados (como nanomateriais), exploração avançada de petróleo e gás e energias renováveis (como eólica, solar, biomassa, oceânica, geotérmica). De acordo com Laplane (2015), o processo de reorganização da indústria advirá da concorrência entre firmas e governos para auferir benefícios e vantagens econômicas e políticas de novas oportunidades de negócios e para restaurar o crescimento e o dinamismo econômicos.

As estratégias para combinar novas formas de inserção são distintas e devem ser acompanhadas, como ressalta Laplane (2015), de mudanças na organização da economia e da sociedade, entre as quais a regulação de conflitos entre o interesse público e privado e entre o capital e o trabalho. Cabe notar que as diversas inovações que estão sendo buscadas podem criar novos mercados sem contrapartida significativa nos empregos. A substituição de mão de obra pela inovação em meio à concorrência pode ter efeitos negativos sobre os trabalhadores ou mesmo o consumo. Também a liberalização de mercados para a integração a cadeias globais e incorporação de componentes importados não é neutra nos efeitos sobre a base produtiva das economias e pode gerar piora nas capacidades acumuladas internamente e diminuir o adensamento industrial interno.

\subsubsection{Vulnerabilidade e balança comercial da economia brasileira}

O desempenho da balança comercial nos últimos anos tem piorado a posição brasileira quanto à restrição externa ao crescimento e à vulnerabilidade. Esse desempenho, que ficou velado em razão dos preços de determinados bens básicos exportados pela economia brasileira, tem-se deteriorado. Como se verá na próxima seção, as diferenças setoriais e em termos tecnológicos são centrais para essa piora. As relações entre o desempenho comercial e a indústria podem definir inserção internacional deletéria para a economia.

A vulnerabilidade das economias em desenvolvimento apresenta traços estruturais. A exposição ao ciclo econômico mundial é diferenciada pelo grau de desenvolvimento. Diversos autores explicam o ciclo financeiro mundial com referência à perspectiva delineada por Minsky inicialmente para economias fechadas. Os países seriam classificados com hedge, especulativo ou ponzi de acordo com a maioria das suas 
unidades econômicas. As economias classificadas na categoria especulativa ou ponzi pelos mercados financeiros mundiais seriam aquelas com menor capacidade relativa em gerar o ingresso líquido de divisas externas necessário (seja pela balança comercial, de serviços e rendas ou pela conta financeira) para honrar seus compromissos financeiros internacionais. No contexto da inserção internacional é significativa a existência de ciclos reflexos no desenvolvimento brasileiro, em razão da vulnerabilidade externa e da fragilidade financeira da economia brasileira, destacam Amado e Resende (2007) e Santiago et al. (2009) e Amado e Caruso (2011) ${ }^{174}$.

A evolução recente do balanço de pagamentos brasileiro pode indicar elementos da vulnerabilidade externa. Enquanto em meados da década de 1990 houve déficit em transações correntes em razão da abertura econômica e câmbio valorizado, piorado pela balança comercial negativa, foi verificada melhora com o retorno do superávit comercial, até que se observaram superávits nas transações correntes de 2003 a 2007. Com o crescimento econômico, a elasticidade-renda mais alta das importações em relação às exportações e as estratégias de remessas de lucros das empresas, houve piora nas contas de serviços e rendas, ao mesmo tempo em que a balança comercial passou a ter resultados positivo menores e déficit em 2014. Dessa forma, as transações correntes pressionaram, quase que crescentemente, a necessidade de financiamento externo a partir de 2007.

Gráfico 4. Balanço de Pagamentos brasileiro: contas das transações correntes, $1995-$ 2014, US\$ milhões.

174 De acordo com Resende e Amado (2007), a relação do sistema financeiro internacional com as economias periféricas apresenta natureza distinta daquela observada com as economias centrais, com efeitos sobre o processo de desenvolvimento econômico desigual. As primeiras são classificadas na categoria especulativa/ponzi nos mercados financeiros mundiais, ao passo que as segundas seriam classificas na categoria hedge. O ciclo financeiro internacional apresenta reflexos significativos sobre as economias da periferia. A fase ascendente do ciclo permite expansão do crédito para a periferia, mitigando a incerteza, o que afasta a restrição externa. Na fase descendente, no entanto, o otimismo esvai-se e ocorre racionamento de crédito de maneira assimétrica para a periferia, em razão da incerteza sobre a capacidade de pagamento desses países. Essa situação gera dificuldades e faz com que as economias periféricas se comportem de forma reflexa aos ciclos da liquidez internacional. São razões principais para essa realidade: i) o estilo de desenvolvimento de economias periféricas, associado a uma restrição de divisas externas, conforme analisado pela CEPAL para a América Latina; ii) a necessidade de atração de capitais externos para suprir a economia periférica de financiamento de longo prazo, uma vez que seu sistema financeiro, por ser ainda subdesenvolvido, não cumpre esse papel ; e iii) o comportamento tipicamente minskyano do sistema financeiro internacional. 


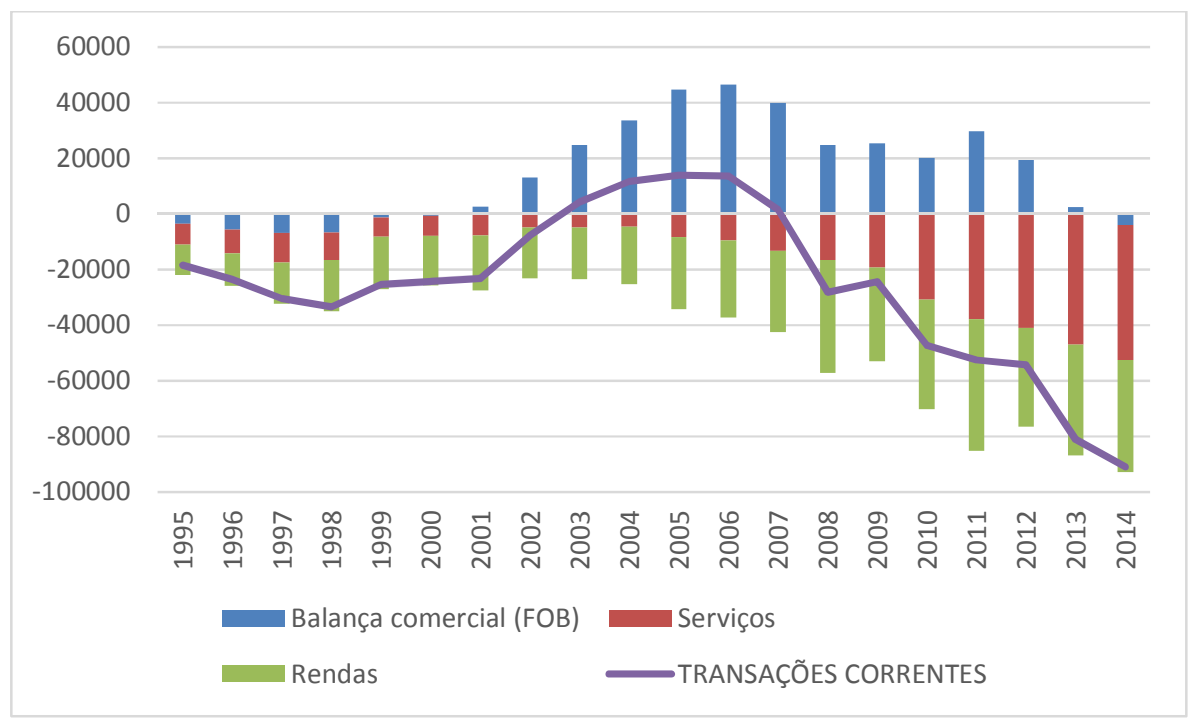

Fonte: BCB. Elaboração própria.

A conta capital e financeira permitiu o financiamento das transações correntes, sem que as dificuldades sejam resolvidas. Embora a entrada de IED e investimentos em carteira tenha permitido sustentar a saída de divisas, esse contexto gera crescimento do passivo externo líquido, com o aumento posterior de envio de lucros e juros pela conta de rendas.

Gráfico 5. Balanço de Pagamentos brasileiro: transações correntes e conta capital e financeira, 1995-2014, US\$ milhões.

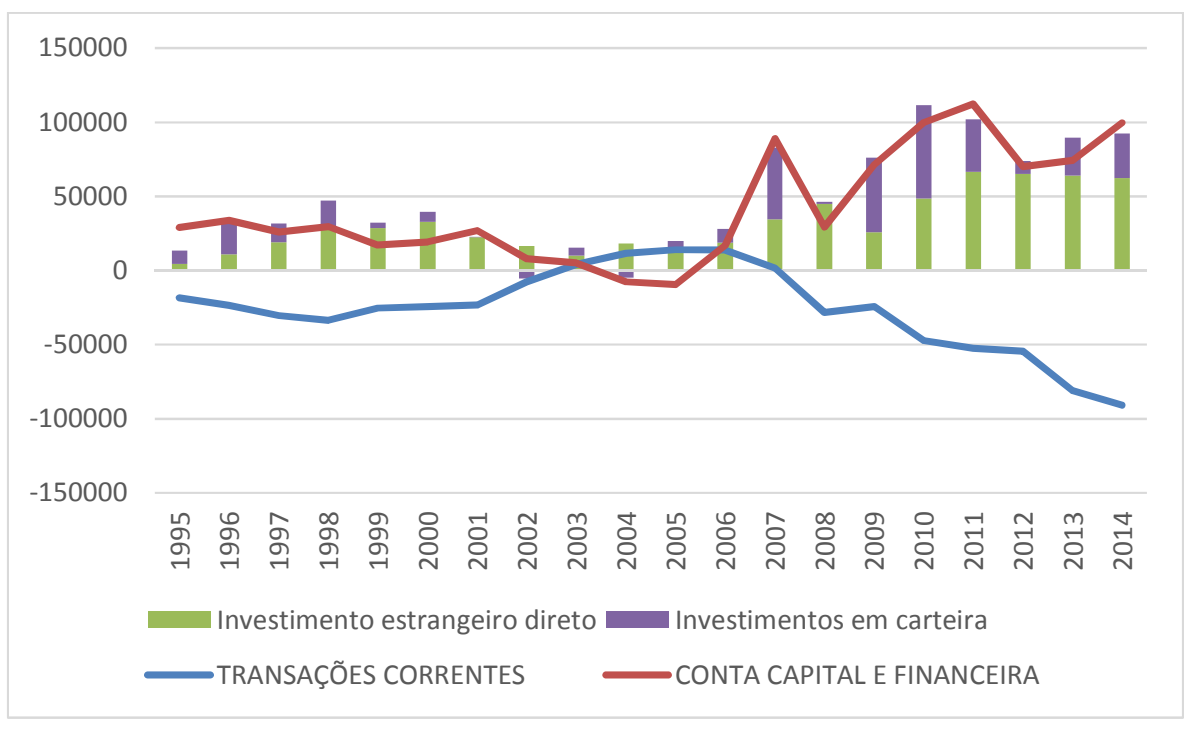

Fonte: BCB. Elaboração própria. 
Os fluxos de investimentos em carteira e dos diretos, apesar da metodologia de apuração que revela interesse mais duradouro destes na comparação com aqueles, podem observar comportamentos próximos, dependendo da regulação brasileira a que estão sujeitos. Corrêa e Almeida Filho (2014) mostram que os fluxos de investimentos diretos se elevaram de patamar quando ocorreu alta no Imposto sobre Operações Financeiras (IOF) para os investimentos em carteira (o que correspondia, à época, a uma forma de quarentena) em dezembro de 2010, quando a pressão desses últimos sobre o câmbio foi considerada excessiva pelos formuladores de política.

O contexto de piora nas contas externas está associado ao desempenho do comércio de bens brasileiro. Como mostrado anteriormente, o déficit na conta de serviços representa significativa restrição externa e tem seguido, de maneira geral, o crescimento econômico interno. A conta de rendas segue o fluxo acumulado de IED, investimentos de portfólio e dívidas, além das necessidades de recursos das matrizes das empresas transnacionais. A balança comercial tem servido para realizar certo ajuste nas contas externas, possibilitando, em determinados momentos, redução ou mesmo eliminação do déficit em transações correntes.

Apesar de historicamente ter sido verificado superávit comercial de bens, a composição setorial das exportações e importações pode revelar limites ao desempenho sustentado dessa balança comercial e efeitos deletérios sobre a produção interna.

A evolução recente do comércio exterior brasileiro parece ter sido marcada por especialização regressiva na última década, com queda na participação das exportações da indústria e de setores com maior conteúdo tecnológico, bem como certa recomposição das importações em direção a setores com maior conteúdo tecnológico. Autores como Squeff (2012) e Gonçalves (2013) observam essa mudança na estrutura da balança comercial. Alguns indicadores permitem distinguir tendências recentes do desempenho brasileiro no comércio de bens e serviços, mas também nas cadeias de valor globais e na interação entre os valores adicionados que são transacionados no comércio mundial.

\subsubsection{Mudança estrutural recente no comércio exterior brasileiro}

\subsubsection{Comércio exterior, inovação e tecnologia}

O desempenho do comércio exterior está associado à base tecnológica da economia. Nesse sentido, a inovação tecnológica, o aprendizado e a interação com o 
padrão de especialização contribuem para definir o crescimento relativo na economia internacional, como destacam Dosi et al. (1990), Fagerberg (1994), Fagerberg e Srholec (2004) e Cimoli et al. (2011). A partir dessa perspectiva schumpeteriana, sobretudo com base em Dosi et al. (1990), é possível notar que a composição da pauta exportadora pode ter influência no desempenho econômico.

Dosi et al. (1990) discutem a dinâmica do comércio com base, principalmente, nas diferenças tecnológicas dos países e na demanda externa. Os autores descrevem como eficiência ricardiana um aspecto comum na literatura de comércio internacional, a alocação estática segundo vantagens comparativas. Considerando retornos nãodecrescentes, falta de externalidades e dado nível de atividade macroeconômica, os padrões de alocação advindos do comércio serão em geral eficientes nesse sentido. Ainda assim, a improvável satisfação dessas condições e a ocorrência de diferenças, entre países, em preços, produtividades e tecnologia relativos não permite concluir que haverá ganhos para todos os parceiros no comércio, seja no curto ou no longo prazos.

Os efeitos dos padrões de especialização, destacam Dosi et al. (1990), podem ser definidos com relação ao dinamismo tecnológico e ao nível de atividade macroeconômica de acordo com os conceitos de eficiência schumpeteriana, ou dinamismo inovador, e de eficiência keynesiana, relativa ao dinamismo da demanda externa. A eficiência na demanda é derivada da taxa de crescimento consistente com o equilíbrio no balanço de pagamentos, formulada por Thirlwall (1979). A eficiência ricardiana estática não implicaria a obtenção dos outros critérios de eficiência. Os autores salientam que tradeoffs entre efeitos estáticos e dinâmicos são induzidos por fatores como: o caráter cumulativo, de difícil apropriação e local dos avanços tecnológicos; a existência de economias de escala estáticas e dinâmicas; a influência que diferenças tecnológicas entre firmas e países têm sobre os incentivos econômicos aos agentes.

O tradeoff entre eficiência schumpeteriana e alocativa pode ser observado no caso em que o país estiver especializado em setores mais distantes da fronteira tecnológica, o que dificultaria a obtenção de benefícios relativos às melhores oportunidades tecnológicas. Já o tradeoff entre eficiência keynesiana e alocativa pode ser constatado quando houver especialização na exportação de produtos de mais baixa elasticidade, sobretudo em comparação com altas elasticidades de importação.

O sistema econômico apresenta oportunidades tecnológicas diferentes entre produtos e entre setores, notam Dosi et al. (1990). As capacidades tecnológicas de cada firma e cada setor estão associadas com o processo de produção e inovação presente no 
setor, como discute Malerba (2005). Os mecanismos de especialização internacional terão efeito dinâmico, ao selecionar as áreas e setores em que habilidades técnicas vão ser acumuladas mais intensamente e em que a inovação e economias de escala serão desenvolvidas mais intensamente. Ademais, Dosi et al. (1990) salientam que a sinalização das rentabilidades relativas aos agentes econômicos não necessariamente segue as eficiências keynesiana ou schumpeteriana. O mercado pode sinalizar para as firmas projetos mais rentáveis no curto prazo e ineficientes dinamicamente.

Dosi et al. (1990) argumentam que líderes tecnológicos tendem a encontrar padrão de especialização em que a sinalização da lucratividade intersetorial está direcionada para atividades que levam a maior eficiência keynesiana e schumpeteriana. Já os países mais distantes da fronteira tecnológica podem acabar sendo penalizados dinamicamente, por causa do seu padrão atual de eficiência alocativa intersetorial.

De acordo com Fagerberg e Srholec (2004), a capacidade para mudar o padrão de especialização no sentido de setores mais tecnologicamente avançados constitui fator importante para o desempenho econômico. No entanto, padrões de especialização existentes, em razão de caráter cumulativo do progresso tecnológico, tenderão a ser reforçados com o tempo. Dessa forma, a mudança do padrão pode ser difícil e deve requerer a aplicação de diferentes políticas.

O trabalho menos qualificado tem influência também sobre as capacidades das firmas e das economias. Ho (2015) destaca que, para Marx, a especialização em determinados elos ou fases menos qualificados na rede global de operações da produção industrial ou na divisão internacional do trabalho pode significar uma especialização com ausência de desenvolvimento.

\subsubsection{Sofisticação, complexidade e estrutura no comércio}

No caso da atuação no comércio exterior, a forma de especialização pode engendrar padrão regressivo de inserção internacional, o que pode ser observado na literatura estruturalista, mas também em autores recentes discutidos na seção de diversificação produtiva, sendo importante, principalmente, o caráter dinâmico e do perfil tecnológico das exportações.

Tem havido crescente interesse no estudo da diversificação da pauta exportadora como fator associado ao desenvolvimento econômico. Diversos autores têm apresentado 
medidas de sofisticação das exportações, como Lall et al. (2006), ou de complexidade dos bens, como Hausmann et al. (2007) e Hausmann et al. (2011).

Lall et al. (2006) empreenderam criação de índice de sofisticação com base no nível de renda das economias exportadoras e, em geral, encontraram que os produtos mais sofisticados apresentam nível tecnológico mais elevado. Hausmann et al. (2007) desenvolvem índice de nível de renda associado às exportações, parecido com o de Lall (2006), e mostram que há alta correlação entre o crescimento do PIB per capita e a especialização em produtos de maior renda.

Hausmann et al. (2011) formulam abordagem em que explicam o desenvolvimento econômico como processo de aprendizado e acumulação de capacidades para produzir e exportar bens mais complexos. Usando métodos da teoria de redes, eles definem como mais complexos os produtos com maior número de associações no espaço de produtos comercializados no mundo.

É possível notar que, em nível mais agregado e considerando o aspecto tecnológico e inovativo dos produtos, as classificações de bens mais complexos ou que representem maior produtividade ou renda associada devem estar relacionadas com maior conteúdo tecnológico. Uma rápida associação dos produtos mais complexos definidos por Hausmann et al. (2011) mostra que os 200 mais complexos apresentam nível de conteúdo tecnológico alto ou médio-alto segundo a classificação da OCDE.

Dessa forma, o grau de complexidade ou de desenvolvimento relacionado aos produtos sinaliza também o nível de conteúdo tecnológico. Diversos trabalhos que buscam pesquisar o dinamismo no comércio internacional, como Lall (2000), Mayer et al. (2003), Gouvêa e Lima (2010) e Cimoli et al. (2011), têm apresentado evidências dessa relação entre tecnologia e desempenho.

Lall (2000) usa classificação por nível tecnológico para mostrar padrões de exportação de países em desenvolvimento, no período 1985-1998. As estruturas de exportação, por serem path-dependent e menos sujeitas a mudanças, têm implicações para o crescimento e o desenvolvimento. Produtos de baixa tecnologia tendem a crescer menos, enquanto os de alta tecnologia são os que crescem mais rápido no comércio mundial. Mayer et al. (2003) estudaram os produtos mais dinâmicos no comércio mundial no período 1980-2000 e concluíram que os grupos de melhor desempenho foram os de alta e média tecnologia, assim como observaram elevação tecnológica nas exportações dos países em desenvolvimento. 
Gouvêa e Lima (2010) encontram evidência de que a elasticidade-renda das exportações varia diretamente com o nível de conteúdo tecnológico das exportações. Utilizando como marco teórico o modelo de Thirlwall multissetorial de Araujo e Lima (2007) e a classificação construída por Lall (2000), os autores encontraram evidência empírica, para oito países emergentes, de que aumenta a elasticidade-renda conforme se caminha no sentido de maior nível tecnológico nos setores pesquisados: produtos primários, manufaturas baseadas em recursos naturais, manufaturas de baixa tecnologia, manufaturas de média tecnologia e manufaturas de alta tecnologia.

Cimoli et al. (2011), em discussão sobre mudança estrutural, testam a estrutura do comércio e o desenvolvimento econômico para um conjunto de países no período 19902000. Os autores observaram evidência de relação positiva entre crescimento do PIB per capita e participação das exportações de alta tecnologia no total da pauta. Determinados tipos de mudança estrutural, na direção de setores mais tecnologicamente intensivos, favorecem o crescimento.

Desse modo, o conteúdo tecnológico das exportações pode lançar luz sobre aspectos fundamentais desenvolvimento da economia brasileira, que serão discutidos na seção seguinte.

\subsubsection{Evolução do saldo comercial}

A série de exportações por setor CNAE 2.0 da Funcex permite olhar sobre a dinâmica recente que se traduziu em mudanças estruturais na pauta comercial brasileira. Foram considerados 29 setores, dos 30 divulgados pela Funcex ${ }^{175}$, no período 1996-2013. Assim, foram observados 29 setores, entre os quais três da agropecuária, três da indústria extrativa e 23 da indústria de transformação. Os valores em US\$ foram deflacionados pelo índice de preços setorial, com 2006=100, o que faculta observação do valor transacionado a preços constantes em base fixa para a análise da estrutura das exportações e importações.

Cabe entender o papel dos termos de troca, medidos pelo índice de preços de exportação em relação ao índice de preços de importação. As variações de preços de exportação são muitas vezes acompanhadas pelas variações dos preços de importação.

\footnotetext{
${ }^{175}$ Apenas a Extração de carvão mineral não apresentava índice de preços, além de ter reduzida participação no valor total. Assim, foi o único setor retirado da análise.
} 
Dessa forma, os preços parecem ter exercido maior influência sobre os resultados dos setores primários, que são principalmente exportadores.

No período 1996-2014, a balança comercial mostrou resultado negativo em 19962000, em momento de câmbio valorizado (que se desvalorizaria a partir de 1999) e abertura comercial, e passou a registrar sinal positivo a partir de 2001 (crescente e depois decrescente) até o déficit em 2014.

Retirando-se o efeito da variação nos preços, verifica-se que o desempenho geral das exportações e importações implicou mudança no sinal da balança comercial já a partir de 2010. A tendência, retirado o efeito dos preços, parece ser de aprofundamento dos déficits comerciais.

Gráfico 6. Exportações e importações brasileiras totais, preços correntes e constantes de 2006, 1996-2014.

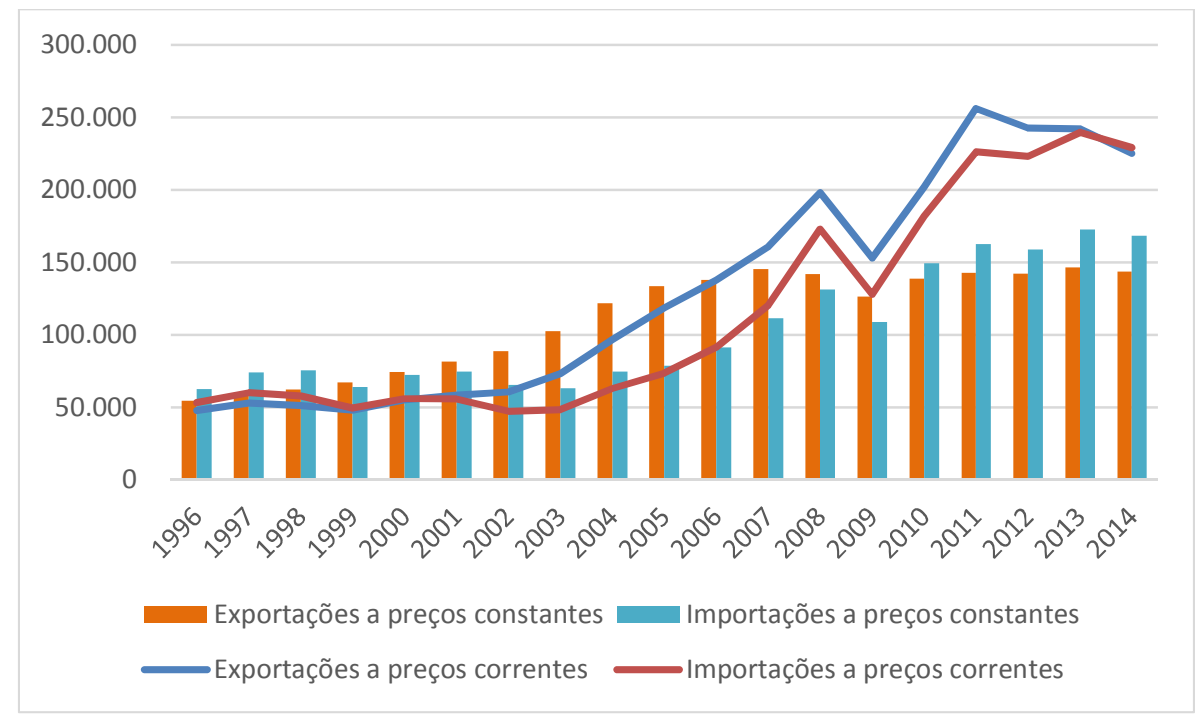

Fonte: Funcex. Elaboração própria.

Gráfico 7. Balança comercial, preços correntes e constantes de 2006, 1996-2014. 


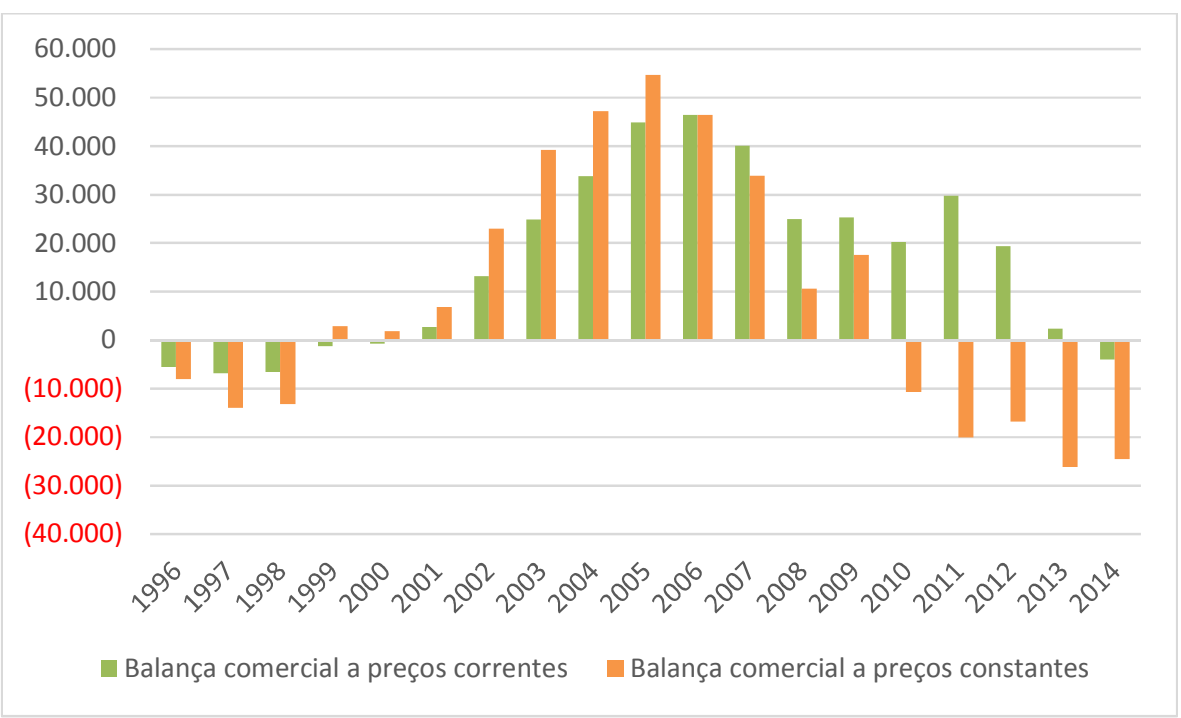

Fonte: Funcex. Elaboração própria.

Em nível setorial, conforme os dados da Funcex, observa-se mudança na estrutura das exportações e importações que pode estar associada a efeitos dinâmicos deletérios para a economia. Normalizando os dados da balança comercial por setor pela corrente de comércio total, obtém-se quadro relativo, mostrado na tabela abaixo, em que setores industriais importantes para o saldo desde 2000 tiveram queda no desempenho e passaram a contribuir para a piora na situação da balança comercial como um todo, como é o caso de metalurgia e veículos automotores. A melhora em bens agropecuários e minerais não tem sido suficiente para sustentar o resultado geral, que tem sido agravado por setores como equipamentos de informática, eletrônicos e ópticos; máquinas, aparelhos e materiais elétricos; produtos químicos; e máquinas e equipamentos.

Tabela 2. Balança comercial setorial normalizada, percentuais por setor CNAE 2.0 a preços constantes de 2006, anos selecionados.

\begin{tabular}{|c|c|c|c|c|c|c|c|c|}
\hline Setores da CNAE & 2000 & 2002 & 2004 & 2006 & 2008 & 2010 & 2012 & 2014 \\
\hline Agricultura e pecuária & $1,6 \%$ & $3,3 \%$ & $3,6 \%$ & $3,6 \%$ & $3,2 \%$ & $3,7 \%$ & $4,1 \%$ & $5,3 \%$ \\
\hline Produção florestal & $0,0 \%$ & $0,0 \%$ & $0,0 \%$ & $0,0 \%$ & $0,0 \%$ & $0,0 \%$ & $0,0 \%$ & $0,0 \%$ \\
\hline Pesca e aqüicultura & $0,0 \%$ & $0,0 \%$ & $0,0 \%$ & $0,0 \%$ & $0,0 \%$ & $0,0 \%$ & $-0,1 \%$ & $-0,1 \%$ \\
\hline $\begin{array}{l}\text { Extração de petróleo e gás } \\
\text { natural }\end{array}$ & $-5,3 \%$ & $-3,5 \%$ & $-4,4 \%$ & $-1,5 \%$ & $-1,4 \%$ & $0,5 \%$ & $0,1 \%$ & $-1,0 \%$ \\
\hline $\begin{array}{l}\text { Extração de minerais } \\
\text { metálicos }\end{array}$ & $3,6 \%$ & $3,4 \%$ & $3,7 \%$ & $3,7 \%$ & $3,8 \%$ & $4,0 \%$ & $4,2 \%$ & $4,2 \%$ \\
\hline
\end{tabular}




\begin{tabular}{|c|c|c|c|c|c|c|c|c|}
\hline $\begin{array}{l}\text { Extração de minerais não- } \\
\text { metálicos }\end{array}$ & $0,1 \%$ & $0,1 \%$ & $0,2 \%$ & $0,2 \%$ & $0,0 \%$ & $0,1 \%$ & $0,1 \%$ & $0,1 \%$ \\
\hline Produtos alimentícios & $5,5 \%$ & $9,1 \%$ & $10,0 \%$ & $9,1 \%$ & $7,9 \%$ & $7,7 \%$ & $6,9 \%$ & $6,7 \%$ \\
\hline Bebidas & $-0,1 \%$ & $-0,1 \%$ & $-0,1 \%$ & $-0,1 \%$ & $-0,1 \%$ & $-0,2 \%$ & $-0,2 \%$ & $-0,2 \%$ \\
\hline Produtos do fumo & $0,7 \%$ & $0,9 \%$ & $0,9 \%$ & $0,7 \%$ & $0,8 \%$ & $0,5 \%$ & $0,6 \%$ & $0,5 \%$ \\
\hline Produtos têxteis & $-0,1 \%$ & $0,2 \%$ & $0,4 \%$ & $0,2 \%$ & $-0,1 \%$ & $-0,4 \%$ & $-0,2 \%$ & $-0,4 \%$ \\
\hline $\begin{array}{l}\text { Confecção de artigos do } \\
\text { vestuário e acessórios }\end{array}$ & $0,2 \%$ & $0,2 \%$ & $0,2 \%$ & $0,0 \%$ & $-0,1 \%$ & $-0,2 \%$ & $-0,4 \%$ & $-0,5 \%$ \\
\hline $\begin{array}{l}\text { Couros, artefatos de couro, } \\
\text { artigos para viagem e calçados }\end{array}$ & $2,0 \%$ & $2,0 \%$ & $1,9 \%$ & $1,6 \%$ & $0,9 \%$ & $0,7 \%$ & $0,6 \%$ & $0,6 \%$ \\
\hline Produtos de madeira & $1,3 \%$ & $1,6 \%$ & $1,8 \%$ & $1,4 \%$ & $0,8 \%$ & $0,5 \%$ & $0,4 \%$ & $0,5 \%$ \\
\hline $\begin{array}{l}\text { Celulose, papel e produtos de } \\
\text { papel }\end{array}$ & $0,8 \%$ & $1,1 \%$ & $1,2 \%$ & $1,3 \%$ & $1,1 \%$ & $1,2 \%$ & $1,1 \%$ & $1,4 \%$ \\
\hline $\begin{array}{l}\text { Impressão e reprodução de } \\
\text { gravações }\end{array}$ & $-0,2 \%$ & $-0,2 \%$ & $0,0 \%$ & $0,0 \%$ & $-0,1 \%$ & $-0,1 \%$ & $-0,1 \%$ & $-0,1 \%$ \\
\hline $\begin{array}{l}\text { Derivados do petróleo } \\
\text { biocombustíveis e coque }\end{array}$ & $-5,4 \%$ & $-2,6 \%$ & $-0,1 \%$ & $0,0 \%$ & $-0,7 \%$ & $-2,6 \%$ & $-2,1 \%$ & $-3,1 \%$ \\
\hline Produtos químicos & $-3,8 \%$ & $-3,5 \%$ & $-4,1 \%$ & $-3,0 \%$ & $-4,4 \%$ & $-4,0 \%$ & $-4,6 \%$ & $-5,7 \%$ \\
\hline $\begin{array}{l}\text { Produtos farmoquímicos } \\
\text { farmacêuticos }\end{array}$ & $-1,6 \%$ & $-1,6 \%$ & $-1,3 \%$ & $-1,2 \%$ & $-1,3 \%$ & $-1,5 \%$ & $-1,4 \%$ & $-1,6 \%$ \\
\hline $\begin{array}{l}\text { Produtos de borracha e de } \\
\text { material plástico }\end{array}$ & $-0,1 \%$ & $-0,1 \%$ & $0,0 \%$ & $-0,1 \%$ & $-0,4 \%$ & $-0,7 \%$ & $-0,9 \%$ & $-1,0 \%$ \\
\hline $\begin{array}{l}\text { Produtos de minerais não- } \\
\text { metálicos }\end{array}$ & $0,4 \%$ & $0,5 \%$ & $0,7 \%$ & $0,7 \%$ & $0,3 \%$ & $0,0 \%$ & $-0,2 \%$ & $-0,1 \%$ \\
\hline Metalurgia & $5,3 \%$ & $6,0 \%$ & $5,6 \%$ & $4,9 \%$ & $2,6 \%$ & $1,2 \%$ & $1,9 \%$ & $2,0 \%$ \\
\hline $\begin{array}{l}\text { Produtos de metal, exceto } \\
\text { máquinas e equipamentos }\end{array}$ & $-0,1 \%$ & $0,0 \%$ & $0,2 \%$ & $-0,1 \%$ & $-0,2 \%$ & $-0,7 \%$ & $-0,8 \%$ & $-1,0 \%$ \\
\hline $\begin{array}{l}\text { Equipamentos de informática, } \\
\text { produtos eletrônicos e ópticos }\end{array}$ & $-4,9 \%$ & $-3,1 \%$ & $-3,5 \%$ & $-4,6 \%$ & $-6,8 \%$ & $-7,1 \%$ & $-6,7 \%$ & $-6,2 \%$ \\
\hline $\begin{array}{l}\text { Máquinas, aparelhos e } \\
\text { materiais elétricos }\end{array}$ & $-0,8 \%$ & $-0,9 \%$ & $0,0 \%$ & $-0,2 \%$ & $-0,7 \%$ & $-1,5 \%$ & $-1,7 \%$ & $-1,9 \%$ \\
\hline Máquinas e equipamentos & $-2,1 \%$ & $-2,0 \%$ & $0,2 \%$ & $-0,6 \%$ & $-2,8 \%$ & $-4,3 \%$ & $-5,2 \%$ & $-4,7 \%$ \\
\hline $\begin{array}{l}\text { Veículos automotores, } \\
\text { reboques e carrocerias }\end{array}$ & $0,9 \%$ & $1,9 \%$ & $3,9 \%$ & $3,6 \%$ & $0,3 \%$ & $-1,8 \%$ & $-2,5 \%$ & $-2,9 \%$ \\
\hline $\begin{array}{l}\text { Outros equip. de transporte, } \\
\text { exceto veículos automotores }\end{array}$ & $0,9 \%$ & $0,8 \%$ & $1,6 \%$ & $0,6 \%$ & $0,8 \%$ & $-0,1 \%$ & $0,3 \%$ & $0,4 \%$ \\
\hline Móveis & $0,3 \%$ & $0,4 \%$ & $0,5 \%$ & $0,4 \%$ & $0,2 \%$ & $0,1 \%$ & $0,0 \%$ & $0,0 \%$ \\
\hline Indústrias diversas & $-0,1 \%$ & $0,0 \%$ & $0,0 \%$ & $-0,1 \%$ & $-0,2 \%$ & $-0,4 \%$ & $-0,6 \%$ & $-0,7 \%$ \\
\hline Balança Total & $-1,0 \%$ & $13,9 \%$ & $23,1 \%$ & $20,2 \%$ & $3,4 \%$ & $-5,4 \%$ & $-7,5 \%$ & $-9,4 \%$ \\
\hline
\end{tabular}

Fonte: Funcex. Elaboração própria. 
Obs.: a balança total é calculada pela soma dos setores.

Uma medida utilizada na avaliação do desempenho setorial no comércio exterior é a contribuição à balança comercial. Autores como Lafay (1989) e Bekerman e Dulcich (2013) justificam de maneira teórica e aplicada essa medida pela forma como indica o padrão de especialização setorial. É definido índice que contrasta o resultado da balança do setor com valor hipotético de distribuição setorial equilibrada segundo a balança geral (ou de grupos de setores). Valores positivos denotam vantagem comparativa revelada baseada no padrão de especialização da economia, ao passo que valores negativos representam desvantagem comparativa. A notação da OCDE (2009) pode utilizada para esse indicador:

$$
\left(X_{i}-M_{i}\right)-(X-M)\left[\frac{\left(X_{i}+M_{i}\right)}{(X+M)}\right]
$$

Sendo exportações (X) e importações (M). O subscrito i representa o setor, enquanto os totais não têm subscrito.

A evolução de setores selecionados evidencia desempenhos variados, como notado nos gráficos 9, 10 e 11 abaixo. Percebe-se em que medida as contribuições ao saldo comercial evoluíram desde meados da década de 1990 até meados da década de 2010, pelos dados a preços constantes de 2006. Houve melhor desempenho comparativo em bens primários e extrativos, conquanto tenha ocorrido piora expressiva em bens com maior conteúdo tecnológico e associados a bens intermediários e de capital essenciais para a estrutura produtiva brasileira, como produtos químicos; produtos farmoquímicos e farmacêuticos; equip. de informática, eletrônicos e ópticos; máquinas, aparelhos e materiais elétricos; e máquinas e equipamentos. O setor de veículos automotores, responsável por bens de consumo duráveis e bens de capital relevantes, também vem piorando o desempenho.

Gráfico 8. Contribuição ao saldo comercial, setores selecionados com melhora no desempenho, 1996-2014. 


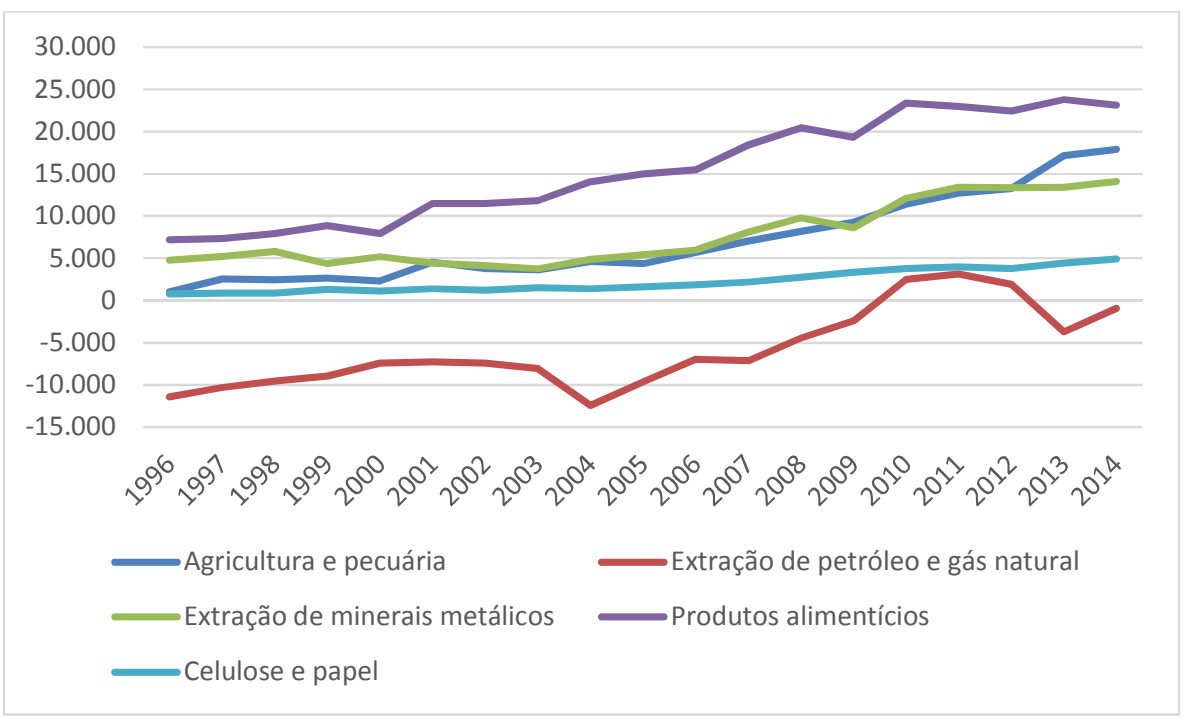

Fonte: Funcex. Elaboração própria.

Gráfico 9. Contribuição ao saldo comercial, setores selecionados com piora no desempenho, 1996-2014.

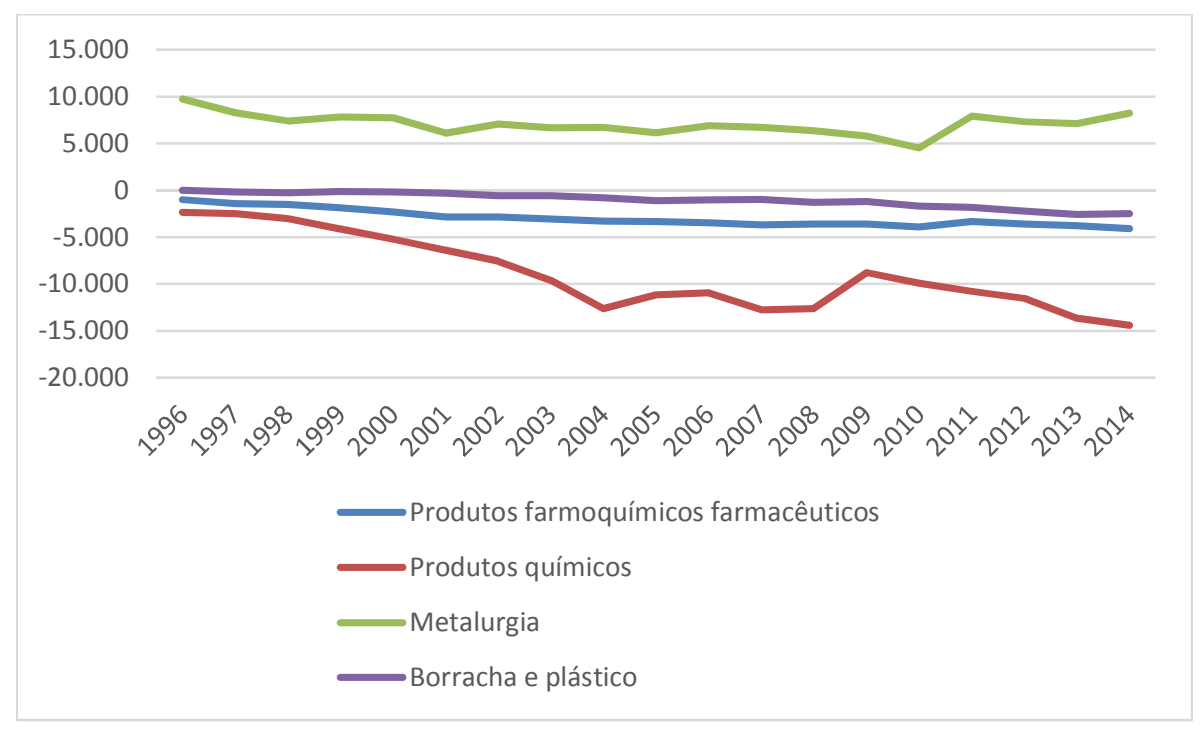

Fonte: Funcex. Elaboração própria.

Gráfico 10. Contribuição ao saldo comercial, setores selecionados com piora no desempenho, 1996-2014. 


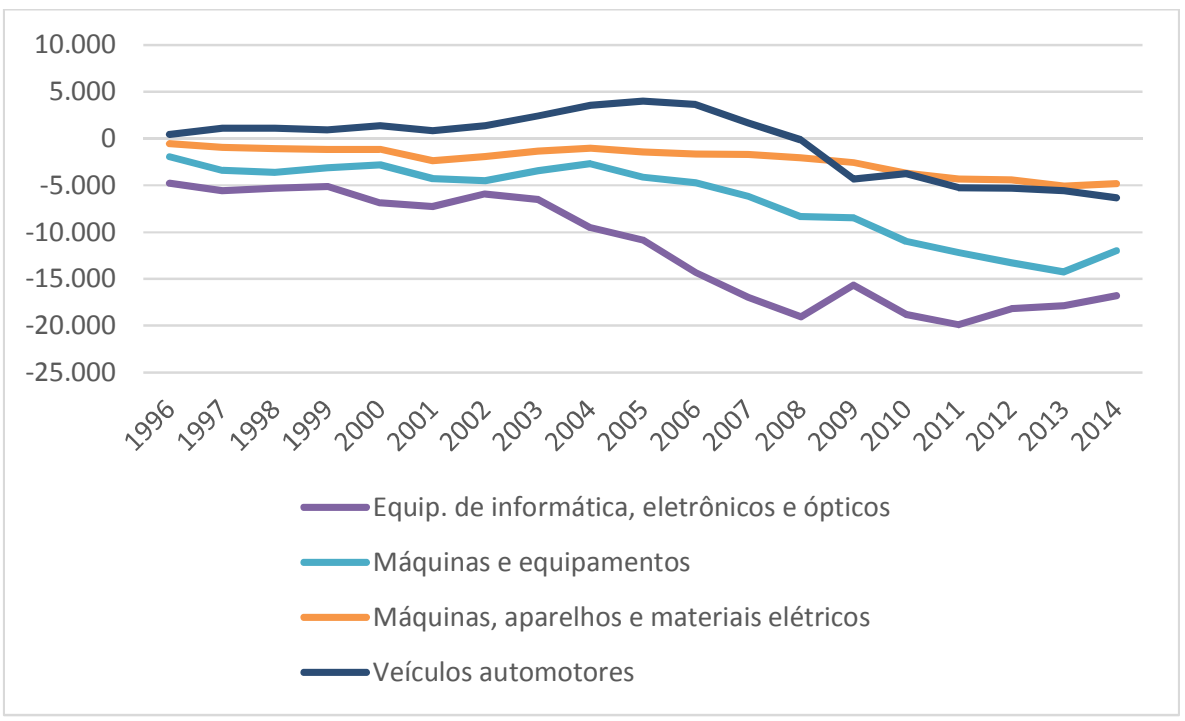

Fonte: Funcex. Elaboração própria.

\subsubsection{Mudança estrutural nas exportações e importações}

A modificação no resultado comercial tem sido acompanhada de alterações na estrutura das exportações e importações. Memedovic e Iapadre (2010) utilizam indicador, o índice de dissimilaridade de Finger-Kreinin, para medir a mudança estrutural em determinada distribuição ${ }^{176}$, o qual pode ser utilizado para notar diferenças na composição de exportações e importações. $\mathrm{O}$ índice, que varia de 0 a 1 , mensura como determinada distribuição de i setores em um período, a, se distingue de outro, b, e pode ser definido por D:

$$
D=1 / 2 \sum_{i=1}^{n}\left|a_{i}-b_{i}\right|
$$

Nota-se que um índice d pode ainda denotar a influência de cada setor i para a mudança estrutural, como na definição:

$$
d_{i}=\frac{1}{2}\left|a_{i}-b_{i}\right|
$$

\footnotetext{
${ }^{176}$ Outra aplicação recente, para a estrutura interna da economia brasileira no período 1995-2009, foi feita por Amitrano et al. (2014), que denominam o indicador de índice de mudança estrutura de Amsden.
} 
O índice foi calculado para os períodos de 1996-2002, 2002-2008, 2008-2014 e 1996-2014, tanto para exportações quanto para importações, e revela algumas diferenças entre os setores. No período 1996-2014, houve mudança em 22,3\% na distribuição das exportações e $24,8 \%$ na distribuição das importações. Nos subperíodos, nota-se que as importações sofreram maior mudança em 2002-2008, enquanto que as exportações se modificaram mais em 1996-2002 e em 2008-2014. Em 1996-2014, as mudanças nas exportações foram maiores em Agricultura e pecuária; Extração de petróleo e gás natural; Produtos alimentícios; Couros, artefatos de couro, artigos para viagem e calçados; Produtos químicos; Metalurgia; Veículos automotores, reboques e carrocerias; e Outros equipamentos de transporte, exceto veículos automotores. Merecem destaque também, por causa da mudança nas importações, os setores de Extração de petróleo e gás natural; Derivados do petróleo biocombustíveis e coque; Produtos químicos; Equipamentos de informática, produtos eletrônicos e ópticos; Máquinas e equipamentos; Veículos automotores, reboques e carrocerias; e Outros equipamentos de transporte, exceto veículos automotores.

Tabela 3. Índice de Mudança Estrutural, periodos selecionados, setores CNAE 2.0.

\begin{tabular}{|c|c|c|c|c|c|c|c|c|}
\hline & \multicolumn{2}{|c|}{ 1996-2002 } & \multicolumn{2}{|c|}{$2002-2008$} & \multicolumn{2}{|c|}{$2008-2014$} & \multicolumn{2}{|c|}{ 1996-2014 } \\
\hline & Exp. & Imp. & Exp. & Imp. & Exp. & Imp. & Exp. & Imp. \\
\hline $\begin{array}{l}\text { Índice de Mudança } \\
\text { Estrutural }\end{array}$ & $14,4 \%$ & $12,8 \%$ & $10,3 \%$ & $17,8 \%$ & $12,7 \%$ & $11,1 \%$ & $22,3 \%$ & $24,8 \%$ \\
\hline Agricultura e pecuária & $1,6 \%$ & $0,0 \%$ & $0,3 \%$ & $0,8 \%$ & $2,8 \%$ & $0,1 \%$ & $4,2 \%$ & $0,9 \%$ \\
\hline Produção florestal & $0,0 \%$ & $0,0 \%$ & $0,0 \%$ & $0,0 \%$ & $0,0 \%$ & $0,0 \%$ & $0,1 \%$ & $0,0 \%$ \\
\hline Pesca e aqüicultura & $0,0 \%$ & $0,0 \%$ & $0,0 \%$ & $0,0 \%$ & $0,0 \%$ & $0,0 \%$ & $0,0 \%$ & $0,1 \%$ \\
\hline $\begin{array}{l}\text { Extração de petróleo e } \\
\text { gás natural }\end{array}$ & $2,4 \%$ & $2,3 \%$ & $0,4 \%$ & $2,8 \%$ & $0,3 \%$ & $1,9 \%$ & $3,5 \%$ & $5,8 \%$ \\
\hline $\begin{array}{l}\text { Extração de minerais } \\
\text { metálicos }\end{array}$ & $1,2 \%$ & $0,1 \%$ & $0,5 \%$ & $0,4 \%$ & $0,8 \%$ & $0,3 \%$ & $0,1 \%$ & $0,5 \%$ \\
\hline $\begin{array}{l}\text { Extração de minerais } \\
\text { não-metálicos }\end{array}$ & $0,0 \%$ & $0,0 \%$ & $0,0 \%$ & $0,1 \%$ & $0,0 \%$ & $0,0 \%$ & $0,0 \%$ & $0,0 \%$ \\
\hline Produtos alimentícios & $1,1 \%$ & $0,5 \%$ & $0,6 \%$ & $0,6 \%$ & $0,3 \%$ & $0,1 \%$ & $0,8 \%$ & $0,8 \%$ \\
\hline Bebidas & $0,0 \%$ & $0,1 \%$ & $0,0 \%$ & $0,1 \%$ & $0,0 \%$ & $0,0 \%$ & $0,0 \%$ & $0,1 \%$ \\
\hline Produtos do fumo & $0,5 \%$ & $0,0 \%$ & $0,1 \%$ & $0,0 \%$ & $0,1 \%$ & $0,0 \%$ & $0,7 \%$ & $0,0 \%$ \\
\hline Produtos têxteis & $0,1 \%$ & $0,5 \%$ & $0,1 \%$ & $0,3 \%$ & $0,2 \%$ & $0,0 \%$ & $0,2 \%$ & $0,1 \%$ \\
\hline $\begin{array}{l}\text { Confecção de artigos do } \\
\text { vestuário e acessórios }\end{array}$ & $0,0 \%$ & $0,2 \%$ & $0,1 \%$ & $0,1 \%$ & $0,1 \%$ & $0,3 \%$ & $0,2 \%$ & $0,2 \%$ \\
\hline $\begin{array}{l}\text { Couros, artefatos de } \\
\text { couro, artigos para } \\
\text { viagem e calçados }\end{array}$ & $0,6 \%$ & $0,1 \%$ & $0,8 \%$ & $0,1 \%$ & $0,4 \%$ & $0,0 \%$ & $1,5 \%$ & $0,1 \%$ \\
\hline Produtos de madeira & $0,3 \%$ & $0,0 \%$ & $0,6 \%$ & $0,0 \%$ & $0,6 \%$ & $0,0 \%$ & $0,6 \%$ & $0,1 \%$ \\
\hline $\begin{array}{l}\text { Celulose, papel } \\
\text { produtos de papel }\end{array}$ & $0,3 \%$ & $0,4 \%$ & $0,2 \%$ & $0,0 \%$ & $0,5 \%$ & $0,1 \%$ & $0,5 \%$ & $0,5 \%$ \\
\hline $\begin{array}{l}\text { Impressão e reprodução } \\
\text { de gravações }\end{array}$ & $0,0 \%$ & $0,1 \%$ & $0,0 \%$ & $0,2 \%$ & $0,0 \%$ & $0,0 \%$ & $0,0 \%$ & $0,3 \%$ \\
\hline
\end{tabular}




\begin{tabular}{|c|c|c|c|c|c|c|c|c|}
\hline $\begin{array}{l}\text { Derivados do petróleo } \\
\text { biocombustíveis e coque }\end{array}$ & $0,7 \%$ & $1,6 \%$ & $0,1 \%$ & $2,6 \%$ & $0,4 \%$ & $0,7 \%$ & $0,1 \%$ & $3,1 \%$ \\
\hline Produtos químicos & $0,6 \%$ & $2,4 \%$ & $0,4 \%$ & $0,7 \%$ & $0,2 \%$ & $0,9 \%$ & $0,9 \%$ & $1,9 \%$ \\
\hline $\begin{array}{l}\text { Produtos farmoquímicos } \\
\text { farmacêuticos }\end{array}$ & $0,1 \%$ & $1,0 \%$ & $0,1 \%$ & $0,4 \%$ & $0,3 \%$ & $0,0 \%$ & $0,3 \%$ & $0,8 \%$ \\
\hline $\begin{array}{l}\text { Produtos de borracha e } \\
\text { de material plástico }\end{array}$ & $0,1 \%$ & $0,3 \%$ & $0,1 \%$ & $0,2 \%$ & $0,2 \%$ & $0,3 \%$ & $0,1 \%$ & $0,7 \%$ \\
\hline $\begin{array}{l}\text { Produtos de minerais } \\
\text { não-metálicos }\end{array}$ & $0,1 \%$ & $0,0 \%$ & $0,1 \%$ & $0,1 \%$ & $0,2 \%$ & $0,2 \%$ & $0,0 \%$ & $0,3 \%$ \\
\hline Metalurgia & $2,9 \%$ & $0,7 \%$ & $2,1 \%$ & $0,2 \%$ & $0,6 \%$ & $0,2 \%$ & $4,7 \%$ & $0,8 \%$ \\
\hline $\begin{array}{l}\text { Produtos de metal, exceto } \\
\text { máquinas } \\
\text { equipamentos }\end{array}$ & $0,1 \%$ & $0,0 \%$ & $0,1 \%$ & $0,2 \%$ & $0,0 \%$ & $0,4 \%$ & $0,1 \%$ & $0,6 \%$ \\
\hline $\begin{array}{l}\text { Equipamentos } r \text { de } \\
\text { informática, produtos } \\
\text { eletrônicos e ópticos }\end{array}$ & $0,3 \%$ & $0,2 \%$ & $0,2 \%$ & $3,4 \%$ & $0,6 \%$ & $1,8 \%$ & $0,1 \%$ & $1,4 \%$ \\
\hline $\begin{array}{l}\text { Máquinas, aparelhos e } \\
\text { materiais elétricos }\end{array}$ & $0,2 \%$ & $0,6 \%$ & $0,3 \%$ & $0,2 \%$ & $0,3 \%$ & $0,6 \%$ & $0,2 \%$ & $0,9 \%$ \\
\hline $\begin{array}{l}\text { Máquinas } \\
\text { equipamentos }\end{array}$ & $0,7 \%$ & $0,7 \%$ & $0,9 \%$ & $1,0 \%$ & $0,7 \%$ & $1,4 \%$ & $0,5 \%$ & $1,8 \%$ \\
\hline $\begin{array}{l}\text { Veículos automotores, } \\
\text { reboques e carrocerias }\end{array}$ & $0,1 \%$ & $0,4 \%$ & $0,9 \%$ & $1,8 \%$ & $1,1 \%$ & $1,4 \%$ & $0,9 \%$ & $1,5 \%$ \\
\hline $\begin{array}{l}\text { Outros equipamentos de } \\
\text { transporte, exceto } \\
\text { veículos automotores }\end{array}$ & $0,5 \%$ & $0,3 \%$ & $1,3 \%$ & $1,1 \%$ & $1,9 \%$ & $0,2 \%$ & $1,6 \%$ & $1,0 \%$ \\
\hline Móveis & $0,1 \%$ & $0,0 \%$ & $0,1 \%$ & $0,0 \%$ & $0,1 \%$ & $0,1 \%$ & $0,1 \%$ & $0,1 \%$ \\
\hline Indústrias diversas & $0,0 \%$ & $0,1 \%$ & $0,0 \%$ & $0,2 \%$ & $0,1 \%$ & $0,1 \%$ & $0,1 \%$ & $0,3 \%$ \\
\hline
\end{tabular}

Fonte: Funcex. Elaboração própria.

Obs: foram utilizados dados a preços constantes de 2006.

\subsubsection{Exportações por intensidade tecnológica}

A série de exportações por intensidade tecnológica produzida pela Secex/MDIC, para o período 1996-2014, em dólares correntes, permite a observação de mudança no desempenho e na composição da pauta comercial em anos recentes.

A normalização dos dados de saldo pela corrente de comércio permite evidenciar movimentos setoriais diferenciados sobre a balança total. As exportações brasileiras de alta e média-alta tecnologia têm apresentado desempenho desfavorável em termos de saldo, o que tem suscitado déficits crescentes nos bens industriais. A indústria de médiabaixa tecnologia passou a representar déficit, a partir de 2010. Apenas a indústria de baixa tecnologia sustentou resultados positivos desde 1996.

Gráfico 11. Balança comercial por intensidade tecnológica, valores normalizados, 1996-2014. 


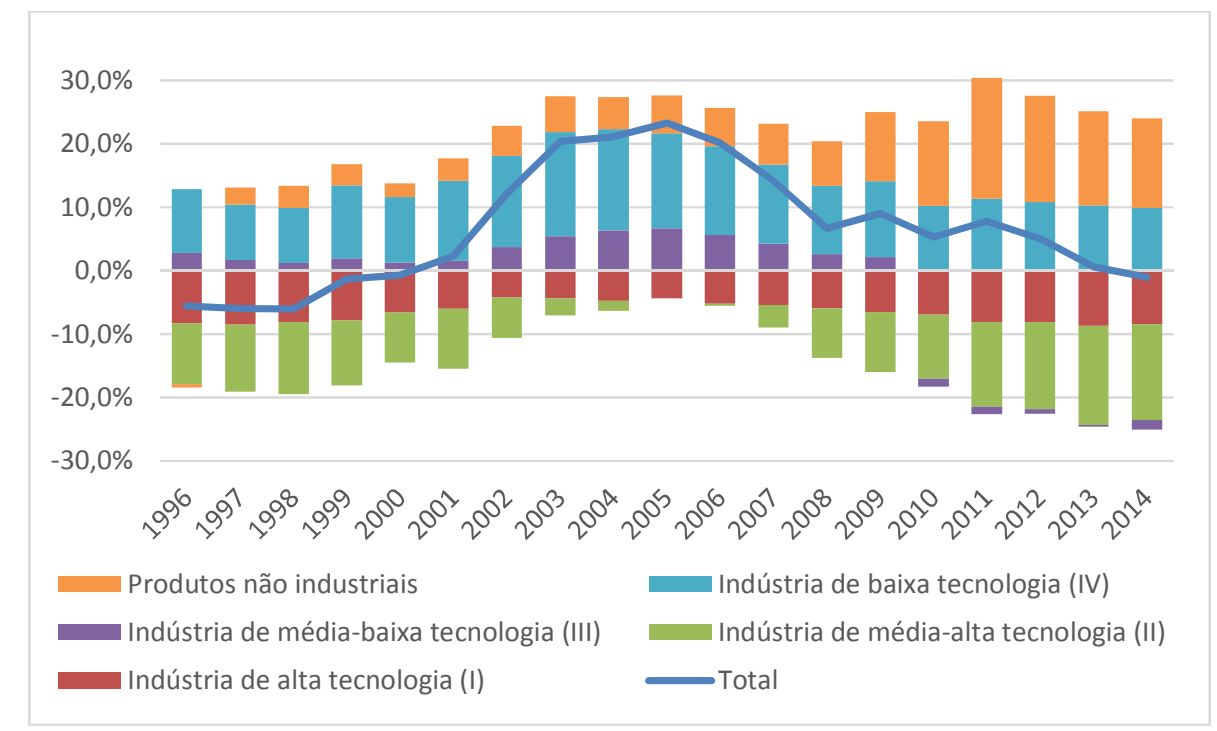

Fonte: Secex/MDIC. Elaboração própria.

O crescimento da importância dos bens não industriais e modificações dentro da própria indústria, como observado em nível de divisão CNAE 2.0, tem efeitos sobre a distribuição da pauta exportadora por intensidade tecnológica. De 1996 a 2005, a parcela da indústria de alta e média-alta tecnologia era, em média, sem grandes variações, em torno de 31\%. Nos gráficos abaixo, verifica-se, entre 2005 e 2014, significativa redução da participação da indústria de alta e média-alta tecnologia no total (de 32\% para 20,5\%), ao mesmo tempo em que ganham espaço os produtos não industriais (de $21 \%$ para $40 \%$ ). Nota-se também que a indústria de alta tecnologia caiu quase pela metade.

Gráfico 12. Participação das exportações por intensidade tecnológica no total, 2005 e 2014. 


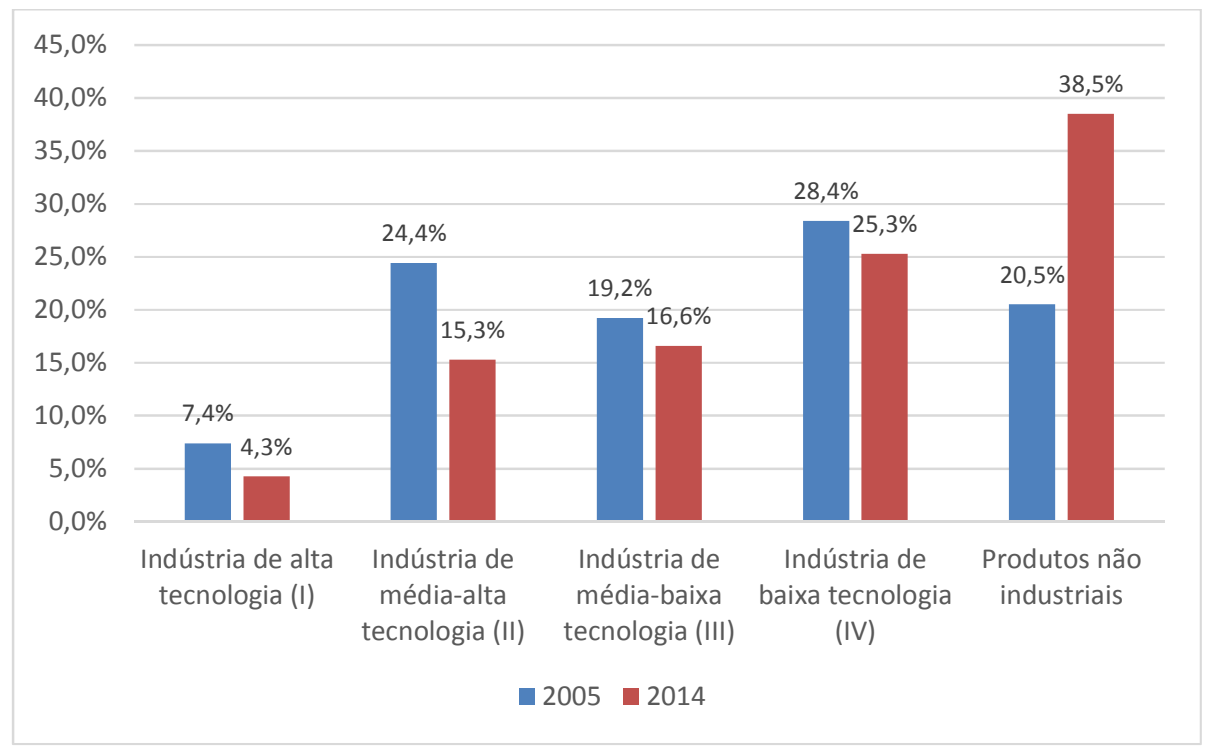

Fonte: Secex/MDIC. Elaboração própria.

Já a pauta importadora tem apresentado modificações na estrutura, menos expressivas do que nas exportações, que indicam maior utilização de bens intermediários, na indústria de média-baixa e baixa tecnologia, mas também equipamentos para transporte no setor de média-alta tecnologia. Os bens não industriais têm perdido participação nas importações.

Gráfico 13. Participação das importações por intensidade tecnológica no total, 2005 e 2014.

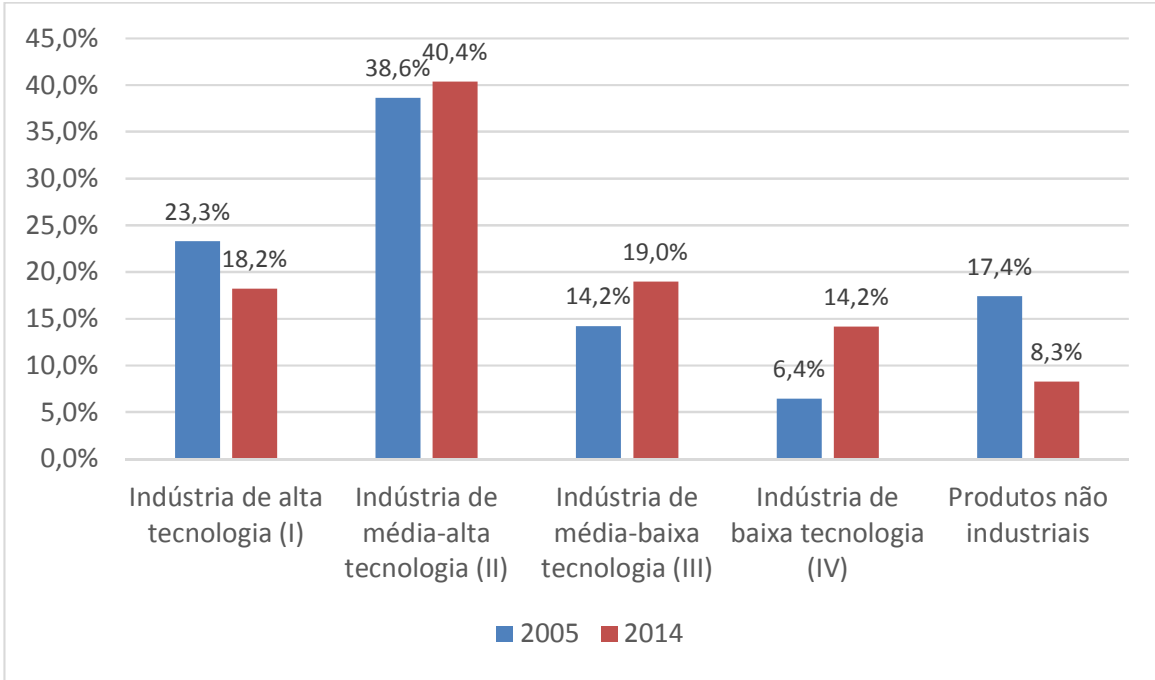

Fonte: Secex/MDIC. Elaboração própria. 


\subsubsection{Comentários Finais}

A participação da economia brasileira na indústria mundial não tem apresentado bom desempenho. Esse quadro e a piora nas transações correntes da economia revelam problemas na estrutura produtiva e na vulnerabilidade externa. A relação entre vulnerabilidade externa e desempenho produtivo e tecnológico pode ser observada por meio da evolução e da estrutura do comércio exterior de bens. A observação dos valores a preços constantes possibilita melhor compreensão da dinâmica e composição das exportações, importações e o saldo comercial. A análise da estrutura por intensidade tecnológica revela mais elementos sobre a natureza da inserção externa recente.

A demanda por produtos brasileiros parece ter sido significativamente influenciada pelos preços de bens não industriais no período recente. O saldo comercial foi muito influenciado por efeito dos preços. Setores associados a bens intermediários e de capital significativos para o desenvolvimento têm mostrado desempenho que resulta em aumento do déficit comercial na indústria e pode substituir produção interna.

O aumento da participação das exportações de bens não industriais em detrimento das exportações de alta tecnologia pode constituir limitação ao desempenho econômico brasileiro, principalmente em virtude da diminuição da eficiência em termos dinâmicos (ou schumpeteriana). Os efeitos dinâmicos sobre a produção interna podem ser deletérios no longo prazo. Igualmente, a dependência externa frente aos mercados compradores de commodities é motivo de preocupação.

\subsection{Mudanças no desenvolvimento produtivo e na indústria}

\subsubsection{Introdução}

A inserção brasileira na economia mundial traz desafios ao desenvolvimento produtivo interno, por causa da piora da participação nas cadeias de mercadorias globais e do aumento da vulnerabilidade da economia brasileira. Esse contexto deve ser determinante para a dinâmica recente do desenvolvimento produtivo brasileiro e das políticas econômicas internas. A partir das contribuições teóricas avaliadas anteriormente 
e do contexto de inserção internacional apresentado, pretende-se discutir, quanto a aspectos essenciais do desenvolvimento produtivo, a política econômica recente e o crescimento.

São discutidas noções gerais sobre política econômica brasileira recente no próximo item. Mudanças na estrutura econômica e na dinâmica industrial são em seguida apresentadas. Por fim, comentários finais acerca das políticas de desenvolvimento são feitos.

\subsubsection{Elementos das políticas econômicas recentes e o desenvolvimento produtivo} no Brasil

O desenvolvimento produtivo brasileiro recente tem como herança o contexto de industrialização e das políticas adotadas, de acordo com perspectivas heterodoxas. Segundo Laplane (2015) e Laplane e Sarti (2006), a economia brasileira havia construído estrutura industrial diversificada na segunda metade do século XX até a década de 1980. No início desta década, como decorrência dos investimentos associados ao II PND, havia sido praticamente completada a substituição de importações, com a internalização da produção industrial de filiais de empresas transnacionais líderes em bens intensivos em tecnologia e a participação de empresas públicas e de capital privado nacional em insumos industriais de uso difundido. Ao longo da década de 1980, houve tentativas de estimular grandes grupos nacionais em direção a setores de informática, biotecnologia e química fina, assim como existiram nesses grupos alguns movimentos de diversificação e internacionalização.

Ainda assim, a instabilidade macroeconômica e a desconfiança quanto aos programas de estabilização da década de 1980 foram determinantes para o rompimento da convenção sobre a expectativa de crescimento de longo prazo, para Belluzzo e Almeida (2002). Consequentemente, a falta de horizonte mais duradouro e o crescimento stop and go impuseram comportamento empresarial predominantemente defensivo em relação às margens de lucro e às decisões de investimento e de endividamento, em meio à estatização e crise da dívida externa ${ }^{177}$.

177 O contexto de níveis baixos de investimento das empresas estrangeiras e públicas e privadas nacionais foi desfavorável a estratégias mais ambiciosas de desenvolvimento industrial, notam Laplane e Sarti (2006). 
A orientação neoliberal que surgiu nesse contexto a partir da década de 1990 implicou abertura comercial, eliminação de subsídios, flexibilização para entrada de capital estrangeiro e privatização do setor produtivo e da infraestrutura estatal. A não adoção de políticas industriais foi seguida explicitamente ${ }^{178}$, destaca por exemplo Laplane (2015). A visão era de que abertura e privatização levariam a uma reorganização benéfica da indústria. No entanto, a privatização desarticulou o setor produtivo estatal e levou a estrutura patrimonial fragmentada e desnacionalização. A resposta das firmas à abertura em contexto de câmbio valorizado e baixo crescimento na demanda interna foi defensiva, com racionalização, especialização e transferência de propriedade para estrangeiros. Ocorreu miniciclo de investimentos entre 1996 e 1998, segundo Bielschowsky et al. (2000), ao mesmo tempo em que foi possível modernização tecnológica via importações de máquinas e equipamentos, em meio a queda no nível de emprego na indústria e piora no desempenho comercial de bens industriais, gerando maior eficiência entre as firmas sobreviventes, mas piora no desempenho industrial em geral (Laplane e Sarti, 2006).

Nesse contexto, Laplane (2015) ressalta que as condições macroeconômicas desfavoráveis ao investimento e à produção somadas à falta de visão pública e privada implicaram uma primeira onda de desindustrialização e perdas de oportunidades que foram aproveitadas por países asiáticos. A estrutura industrial brasileira perdeu o mecanismo de coordenação dos investimentos do setor produtivo estatal e deixou de fortalecer grupos nacionais. Já os países asiáticos ocuparam novos espaços no mercado mundial e em elos importantes de cadeias globais de valor.

Podem ser notadas diferenças nas políticas econômicas a partir de meados da década de 2000 que parecem associadas a nova visão sobre o desenvolvimento nacional. Apesar de mais apoiado na ortodoxia neoliberal, o primeiro governo Lula (2003-2006) revelou, de acordo com Barbosa e Souza (2010), inflexão quanto à visão predominante em 2006, o que levou a novo modelo de desenvolvimento, principalmente durante o segundo governo Lula (2007-2010). Diniz e Boschi (2007) reconheceram novo arcabouço institucional para o desenvolvimento que se mostrava na segunda metade do primeiro

\footnotetext{
178 Salientam Laplane e Sarti (2006) que podem ser notadas exceções como a instalação de Câmaras Setoriais entre empresários, trabalhadores e governo, regimes de proteção ao setor automotivo, além de tentativas de promover fóruns de competitividade no segundo governo Fernando Henrique Cardoso.
} 
governo Lula ${ }^{179}$. Foram obtidos resultados macroeconômicos positivos em termos do crescimento do PIB, fortalecimento de grandes empresas nacionais (estatais e privadas), distribuição de renda e redução da pobreza. Ainda assim, segundo Morais e Saad Filho (2011), propostas conhecidas como novo-desenvolvimentistas foram institucionalizadas apenas parcialmente, assumindo um caráter complementar, uma vez que as políticas macroeconômicas (monetária, cambial e fiscal) neoliberais da década anterior foram mantidas durante o período recente.

Inovações institucionais recentes na política macroeconômica, muitas das quais criadas em contexto de crise e políticas anticíclicas, têm sido associadas ao novo padrão de desenvolvimento. Ainda que seja menos explícita a mudança da perspectiva ortodoxa sobre a condução macroeconômica, diversos elementos indicam mudanças na concepção do papel do Estado na economia. Essas mudanças não parecem ter trajetória linear de incremento da participação governamental ou mesmo evolução consolidada, uma vez que parecem variar conforme o predomínio ou a pressão de interesses de grupos ou classes na disputa pela política econômica.

São dignos de nota, entre as inovações estabelecidas a partir do governo Lula, arranjos institucionais para coordenação e expansão de investimentos e obras de infraestrutura econômica e social (como o Projeto Piloto de Investimentos, Programa de Aceleração do Crescimento, Minha Casa Minha Vida, Programa de Investimentos em Logística), novos marcos regulatórios para compras públicas (Regime Diferenciado de Contratações, Lei de compras governamentais) e políticas de transferência de renda (valorização do salário mínimo, programas de transferência de renda e erradicação da miséria).

É reconhecido também que os trabalhadores foram beneficiados com o desenvolvimento recente, ao haver aumento do salário mínimo e da formalização na economia, como mostra Pochmann $(2014)^{180}$, sem que se verificasse piora no desempenho econômico. A evolução recente possibilitou inclusão social e aumento do mercado de consumo.

O contexto dos últimos anos foi de expansão quase ininterrupta das remunerações dos empregados no PIB de 2004 a 2011, em contraste com a piora na distribuição

179 Houve, por exemplo, mudança no papel do BNDES, que passou a financiar o desenvolvimento produtivo, diferentemente da atuação como agência para executar as privatizações no governo Fernando Henrique Cardoso.

${ }^{180}$ Ver também Sader (2013). 
funcional da renda de 1995 a 2003, conforme os dados das Contas Nacionais, divulgados pelo IBGE. Conforme a Conta de Geração de Renda, a participação da remuneração dos empregados observou trajetória em que passou de 42,6\% do PIB em 1995 para 38,2\% em 2004, a partir de então atingindo 43,6\%. Cabe notar que a remuneração dos empregados não constitui apenas salários, embora seja frequentemente mostrada dessa maneira. Compreendem essa remuneração ordenados e salários e contribuições sociais dos empregadores (efetivas e imputadas). Ao mesmo tempo em que houve melhora na distribuição funcional, ocorreu melhora na distribuição pessoal da renda, como notado pelo coeficiente de Gini. Em particular, foi verificado crescimento no rendimento domiciliar per capita real a partir de 2004, depois de quedas desde 1998.

Gráfico 14. Participação da remuneração dos empregados no PIB, 1995-2011.

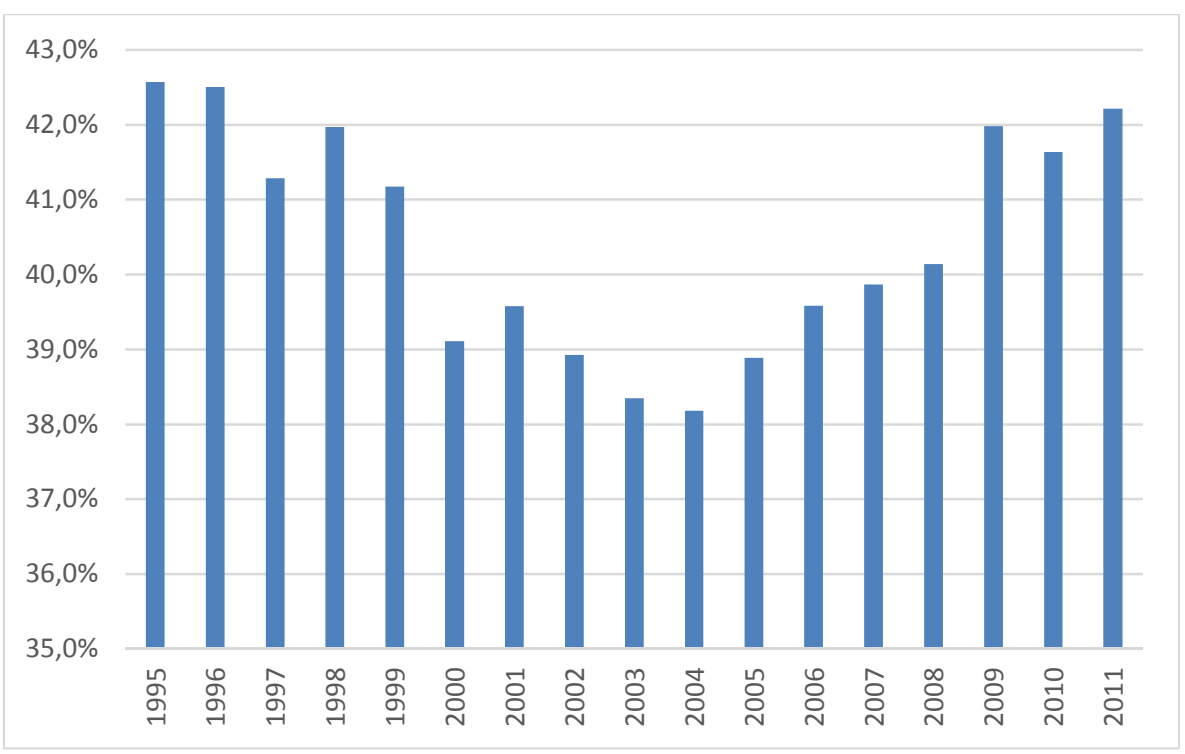

Fonte: SCN/IBGE, referências 2000 (1995-1999) e 2010 (2000-2011). Elaboração própria.

Gráfico 15. Renda domiciliar média per capita ( $R \$$ de outubro de 2013) e coeficiente de Gini, 1995-2013. 


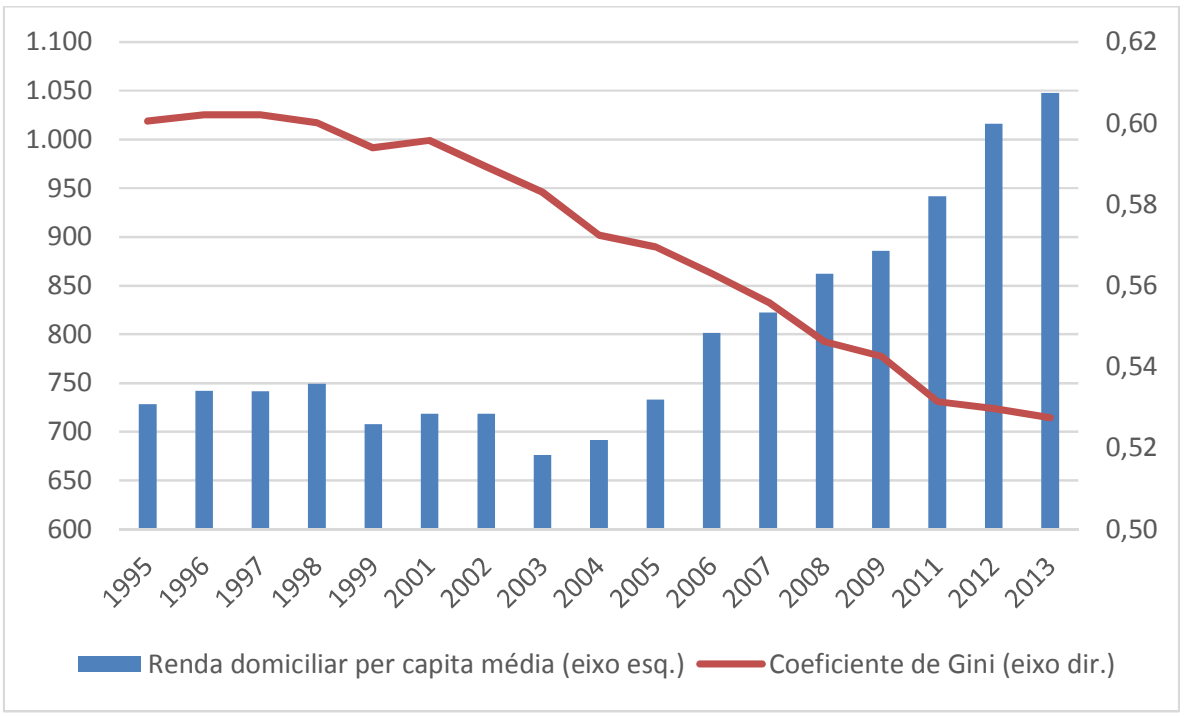

Fonte: IPEAData e PNAD/IBGE. Elaboração própria.

A melhoria na distribuição de renda pode beneficiar o crescimento, como visto no capítulo 3. Existem evidências empíricas que mostram que o aumento da desigualdade tem implicado piora no crescimento, entre estudos recentes associados ao FMI, como Dabla-Norris et al. (2015) e Jaumotte e Osorio-Buitron (2015). De 1990 a 2012, tem crescido substancialmente a desigualdade de renda dentro dos países. As economias desenvolvidas têm verificado alta da desigualdade de renda interna para níveis elevados historicamente. Em média, as economias emergentes e os países menos desenvolvidos, ainda que mostrem nível mais alto do que os países desenvolvidos, têm-se mantido estáveis nessa medida, com piora da desigualdade na Ásia e na Europa do Leste e melhora na América Latina (esta sendo a região mais desigual do mundo). Uma melhora na renda dos $20 \%$ mais ricos piora a expansão do PIB, enquanto a melhora na renda dos $20 \%$ mais pobres eleva o crescimento. A desregulamentação do mercado de trabalho está associada a maior desigualdade, assim como o enfraquecimento dos sindicatos está associado a maior parcela da renda dos 10\% mais ricos. Regras mais flexíveis para contratação, demissão, menores salários mínimos relativos ao salário mediano e negociações salariais coletivas e sindicatos menos predominantes estão associados com maior desigualdade.

A maior desigualdade tem impactos sobre o crescimento pelo aumento relativo do consumo dos mais ricos, cuja propensão a poupar é maior. As bases do trickle-down economics, em que a expansão da renda dos mais ricos seria disseminada em momento seguinte para o restante da economia, parecem contestáveis empiricamente com base na experiência internacional. 


\subsubsection{Retomada de políticas industriais}

Uma das principais mudanças relacionadas com o desenvolvimento produtivo foi a retomada das políticas industriais, em especial com corte explicitamente setorial, após duas décadas de ênfase em políticas macroeconômicas de controle da inflação e de liberalização e diminuição da atividade estatal. Parece presente nas políticas industriais recentes, conforme Laplane (2015), a recuperação da visão estratégica para nortear e coordenar as decisões públicas e privadas de investimento, assim como a aproximação frente às tendências dominantes na indústria globalizada. Foram promovidos 0 fortalecimento e a internacionalização de grandes empresas nacionais para melhorar inserção em cadeias globais, bem como a mobilização de competências para o suporte à inovação, o poder de compra do Estado (em áreas como saúde e defesa). No entanto, as políticas industriais ainda parecem subordinadas à política macroeconômica. Foram três os programas recentes: Política industrial, Tecnológica e de Comércio Exterior (PITCE), para 2004-2007; a Política de Desenvolvimento Produtivo (PDP), para 2008-2010; e o Plano Brasil Maior (PBM), para 2011-2014.

A Política industrial, Tecnológica e de Comércio Exterior (PITCE) foi lançada em 2004 e serviu de contexto e primeiro movimento de retomada, embora em meio a políticas macroeconômicas muito restritivas ${ }^{181}$. Esse programa foi associado à Lei de Inovação promulgada no mesmo ano e à criação do Conselho Nacional de Desenvolvimento Industrial (CNDI) e da Agência Brasileira de Desenvolvimento Industrial (ABDI). Houve foco maior em setores intensivos em tecnologia, como bens de capital, semicondutores, software e fármacos, para gerar ganhos de produtividade e oportunidade de desenvolver sistemas tecnológicos e científicos em áreas como energia, saúde e agricultura. Também ações horizontais e em atividades portadoras de futuro (biotecnologia, nanotecnologia e energias renováveis) foram indicadas.

Em continuidade à PITCE, a Política de Desenvolvimento Produtivo (PDP) foi instituída em 2008, com o objetivo de fortalecer a economia, sustentar o crescimento e

\footnotetext{
181 As relações complexas entre Estado, política macroeconômica e grupos econômicos no Brasil dos últimos 20 anos definiu o contexto da retomada recente de políticas setoriais e de estímulo à indústria. Segundo Laplane e Sarti (2006, p. 314), o governo Lula deixou de lado os preconceitos relativos à política industrial, partindo de uma visão um pouco mais realista sobre a capacidade de promover crescimento e desenvolvimento exclusivamente via políticas macroeconômicas "responsáveis". Parte dessa responsabilidade ficou para a PITCE, contudo as metas fiscais restringiram severamente o tipo de instrumentos e o alcance dos programas governamentais.
} 
incentivar a exportação, tendo como princípios o diálogo com o setor privado e o estabelecimento de metas. A preocupação com o aumento da formação bruta de capital fixo (FBCF) e o ciclo de investimentos que se formava à época do lançamento era central.

Os desafios da PDP eram ampliar a capacidade de oferta, preservar a robustez do balanço de pagamentos, elevar a capacidade de inovação e fortalecer as micro e pequenas empresas. Foram definidas como macrometas o aumento da taxa de investimento; a ampliação da participação das exportações brasileiras no comércio mundial; a elevação do dispêndio provado em P\&D; e ampliação do número de MPEs exportadoras. Foram estruturados 34 programas liderados por comitês executivos e classificados em três grupos: programas mobilizadores em áreas estratégicas (com foco em desafios de ciência, tecnologia e inovação, como nanotecnologia, complexos de defesa, saúde e TICs); programas para aumentar a competitividade (para melhorar competividade interna e produção, como automotivo, bens de capital e têxteis); e programas para consolidar e expandir a liderança (setores com projeção internacional, capacidade competitiva, para inovação e internacionalização de empresas, como aeroespacial, mineração, petróleo e gás e celulose). A crise prejudicou o atingimento das quatro macrometas, enquanto a política foi desenvolvida com base principalmente na necessidade de realizar políticas anticíclicas.

Em 2011, o Plano Brasil Maior (PBM) estabeleceu a política industrial, tecnológica, de serviços e de comércio exterior para o período de 2011 a 2014, aprimorando a estrutura de governança dos fóruns de diálogo com o setor privado. $\mathrm{O}$ foco era a inovação tecnológica e o adensamento produtivo, para criar e fortalecer competências críticas da economia nacional, aumentar o adensamento produtivo e tecnológico das cadeias de valor, ampliar mercados interno e externo das empresas brasileiras e garantir crescimento socialmente inclusivo e ambientalmente sustentável. Nesse sentido, parecem ser importantes as dimensões estruturantes de fortalecimento de cadeias produtivas, de ampliação e criação de novas competências tecnológicas e de negócios e a diversificação das exportações (mercados e produtos) e de internacionalização corporativa.

A estrutura de governança do PBM pretendeu ser mais articulada para a definição de estratégias. O Conselho Nacional de Desenvolvimento Industrial, instância máxima de aconselhamento, é formado por ministros e representantes da sociedade. Também estão presentes um Comitê Gestor e um Grupo Executivo, instâncias de gerenciamento e deliberação formadas, respectivamente, por ministros e secretários-executivos. Foram 
criados 19 conselhos setoriais (em blocos divididos por sistema de mecânica, eletrônica e saúde, intensivos em escala, intensivos em trabalho, agronegócio e comércio, logística e serviços) e nove sistêmicos (como investimento, inovação, comércio exterior e relações de trabalho). Foram estabelecidas medidas iniciais e 10 metas para 2014. O PBM foi vinculado e compartilhou metas com outras políticas, como a Estratégia Nacional de Ciência, Tecnologia e Inovação (2012-2015).

Entre as principais mediadas do PBM estavam estímulos ao investimento e inovação (desonerações Tributárias, financiamento, marco legal da inovação); medidas no comércio exterior (desonerações de exportações, defesa comercial, financiamento e garantias); e defesa da indústria e do mercado interno (desoneração da folha de pagamentos, regime especial automotivo - InovarAuto, compras governamentais, harmonização de políticas de financiamento). É possível notar aspectos relacionados a políticas de inovação e diversificação produtiva, com proteção de determinados setores frente à concorrência estrangeira e importações e aos efeitos do câmbio apreciado.

De acordo com Kupfer et al. (2013), a defesa do mercado interno foi característica marcante do PBM, com medidas para reduzir custos (redução de juros para compra de bens de capital, desonerações na folha de pagamentos, investimentos e exportações e redução da tarifa de energia). Igualmente, a política de margens de preferência para compras públicas, assim como a ênfase em regimes setoriais especiais, para incentivar inovação, eficiência energética e fornecedores locais, dentro das regras da OMC, foram determinantes. Para os autores, precisa haver maior fortalecimento de instituições públicas e privadas para a coordenação na política industrial.

A política industrial tem estado subordinada às restrições da política macroeconômica. Ainda que algumas formas de contornar os mecanismos estabelecidos tenham sido procuradas pelos gestores na área monetária e fiscal, as regras existentes impõem diversas restrições ao uso da política econômica no Brasil. A retomada das políticas industriais e a execução dos programas estiveram sujeitas à política macroeconômica, em geral restritiva e implicando preços relativos desfavoráveis à indústria, e parece não ter alcançado capacidade inequívoca de articulação no setor produtivo.

A partir de 2011, nota Laplane (2015), a deterioração das condições internacionais, a reversão das expectativas, o atendimento do consumo principalmente por importações e a desaceleração dos investimentos privados pioraram o crescimento. Apesar de medidas anticíclicas para manutenção de consumo e redução de impostos que 
mantiveram o emprego e a massa salarial, as expectativas, a produção e os investimentos não foram restaurados.

\subsubsection{Atuação do setor público e ciclo de investimentos}

Uma característica da atuação estatal a partir de meados da década de 2000 tem sido o aumento dos investimentos públicos, após décadas de recuo nessa atividade governamental. Orair (2015) nota que, diferentemente do período desenvolvimentista em 1930-1979, as décadas de 1980 e 1990 representaram momento de retração do investimento público, associadas a constrangimentos orçamentários e ao programa de desestatização, no contexto de desarticulação do padrão de financiamento do setor público, crise nas finanças públicas e reorientação da política econômica. Diversas atividades mais rentáveis foram repassadas à iniciativa privada, enquanto houve concentração de investimentos públicos em determinados segmentos, de maneira isolada, como na infraestrutura de transportes com alto risco e baixa rentabilidade, ou em articulação com o setor privado, como nos ramos de petróleo e gás e energia elétrica.

Pelos novos dados das Contas Nacionais pela Referência 2010, a formação bruta de capital fixo chegou a 16,7\% do PIB em 2003, passando para 20,6\% em 2010 e 2011, embora mostre recuo nos anos seguintes (ver o apêndice 1 para breve comparação de dados na referência anterior). De acordo com a nova série, a proporção do investimento entre 2008 e 2014, exceto pelo ano de 2009, foi maior do que 1997 (19,1\%).

Gráfico 16. Participação da formação bruta de capital fixo no PIB, preços correntes, 1996-2014. 


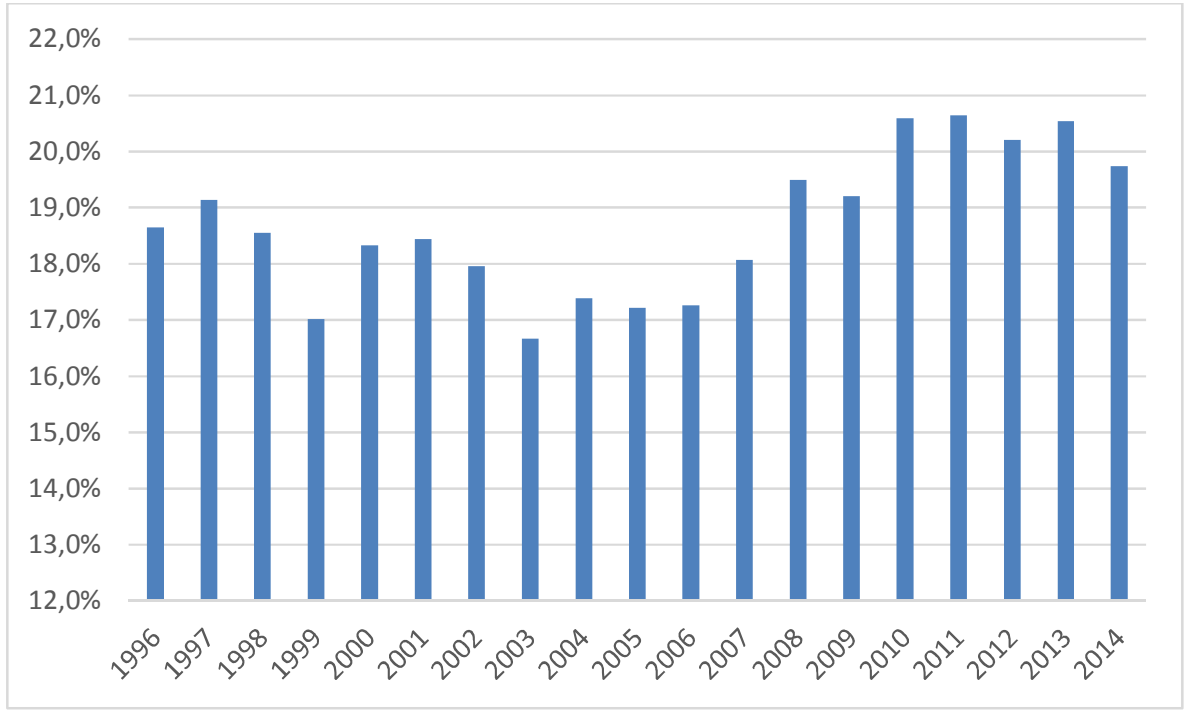

Fonte: SCN/IBGE. Elaboração própria.

Os investimentos públicos tiveram peso importante no crescimento recente da taxa de investimento no PIB. Orair (2015) nota expansão dos investimentos públicos a partir de 2005 até 2010, com oscilação em 2011 e retomada até meados de 2014, de maneira complementar aos investimentos privados, aumentando a taxa de investimento no PIB ${ }^{182}$. Diferentemente do período de 1995 a 2004, no qual o investimento público cresceu abaixo do PIB, o período de 2005 a 2011 observou inversão nessa relação e coincidiu com elevação da taxa de crescimento do PIB. Considerando a administração pública e as empresas públicas federais, os investimentos públicos passaram de 2,5\% para 5,2\% do PIB no período 2004-2010. As empresas públicas federais tiveram maior aceleração a partir de 2007. A retomada dos investimentos adveio principalmente de segmentos de infraestrutura (incluindo petróleo e gás). Cerca de metade dos investimentos públicos das empresas federais é feita pelo grupo Petrobras.

$\mathrm{Na}$ década de 2000, foram retirados entraves fiscais ao investimento de certas empresas estatais. A exclusão da Petrobras e da Eletrobrás da conta do superávit primário, além da possibilidade de exclusão dos gastos no Programa Piloto de Investimentos e no PAC, no segundo governo Lula, constitui medida que possibilita, em tese, maior facilidade para a realização de investimentos. Havia constrangimento significativo dos investimentos das estatais desde a década de 1980 (ver Gobetti e Amado, 2011). Parece

${ }^{182}$ Com efeito, no período 1947-2010, Orair (2015) nota evidência empírica de associação positiva entre investimento público e o crescimento do PIB no Brasil. 
haver mais similaridade com a proposta de orçamento de investimentos de Keynes, para não penalizar o caráter indutor dessa variável sobre o crescimento.

Conforme salientado, a utilização de empresas estatais no desenvolvimento tem sido efetuada de maneira significativa em anos recentes. Parece ter ocorrido certo fortalecimento da atuação estatal indireta e direta por meio de empresas em diversos ramos, como indústria extrativa, serviços públicos, órgãos de pesquisa, atividades estratégicas e instituições financeiras.

Os casos da indústria de petróleo e gás, petroquímica e naval ilustram o desenvolvimento da economia com base no fomento estatal. A definição de um regime próprio, Repetro, e o direcionamento das empresas de capital misto, lideradas pela Petrobras SA, incluindo BR Distribuidora SA e outras, foram essenciais para a reestruturação da acumulação de capital nesses setores, com rebatimento em diversos setores. O capital estatal foi alocado para aumentar a taxa de acumulação do setor de extração e prospecção e gerar encadeamentos na indústria naval ${ }^{183}$ e civil, petroquímica, bens de capital e pesquisa e desenvolvimento. O papel da demanda e poder de compra ampliado da Petrobras e suas afiliadas foi determinante para estabilizar as expectativas de produção e investimento das diversas atividades associadas.

Cabe notar que a inovação praticada pelas empresas estatais é significativa para a economia brasileira. Segundo a Pesquisa de Inovação nas Empresas Estatais Federais 2008, do IBGE (2011), do total de 72 empresas estatais federais dos mais diversos setores de atividade econômica, 49 empresas implementaram produto ou processo novo ou substancialmente aprimorado entre 2006 e 2008. Dessa forma, 68,1\% das empresas estatais federais foram inovadoras, sendo esta taxa de inovação maior que a apresentada pela média dos setores investigados na Pintec 2008 (38,6\%). Além disso, 5 empresas estatais, apesar de não terem inovado, possuíam projetos incompletos em 2008 ou abandonaram algum projeto entre 2006 e 2008. Também se nota que a análise da taxa de inovação segundo o referencial de mercado mostra que $27,8 \%$ das empresas estatais federais realizaram inovação de produto para o mercado nacional e 29,2\% implementaram processo novo para o setor no Brasil. Estes percentuais são bem

\footnotetext{
${ }^{183}$ Campos Neto e Pompermayer (2014) destacam que diversos programas contribuíram para a retomada das indústrias naval e offshore de navipeças, como as políticas: industrial (Plano Brasil Maior), empresariais (Programa de Modernização e Expansão da Frota de Navios Petroleiros - PROMEF da Transpetro/Petrobras), de financiamento (Fundo de Marinha Mercante - FMM) e de capacitação de mão de obra (Programa de Mobilização da Indústria Nacional de Petróleo e Gás Natural - PROMINP). O aumento do conteúdo local exigido aos fornecedores da Petrobras foi essencial para o dinamismo do setor naval.
} 
superiores aos verificados na Pintec 2008 (4,4\% e 2,4\%, respectivamente). O IBGE associa a esse resultado o fato de que grande parte das empresas estatais federais têm a característica de serem as únicas produtoras ou ofertantes de determinados bens ou serviços.

Igualmente, foi verificada maior presença dos bancos públicos na economia. De acordo com dados do saldo de crédito por controle de capital do Banco Central do Brasil, os bancos públicos detinham 38,8\% do estoque de empréstimos em novembro de 2007 (representando queda frente aos 37,8\% de janeiro de 2003) e passaram a 54,5\% em março de 2015, em detrimento principalmente da parcela dos bancos privados nacionais. Políticas de expansão dos empréstimos dos bancos públicos, principalmente a partir de 2011, em conjunto com a diminuição da taxa básica SELIC e o Programa Minha Casa Minha Vida foram determinantes, além da preferência pela liquidez dos bancos privados. A política do BNDES, em atuação coerente para lidar com a deficiência de crédito de longo prazo no Brasil, foi central para promover aumento nas taxas de investimento em setores considerados estratégicos, na inovação, nas exportações, no emprego, na produtividade e na internacionalização de empresas, de acordo com Miterhof et al. (2015).

\subsubsection{Aspectos da dinâmica recente da indústria}

A participação da indústria de transformação no PIB tem diminuído desde 2004, quando chegou a 17,8\%, e atingiu 10,8\% do valor adicionado em 2015 (considerando o acumulado em quatro trimestres até o primeiro trimestre do ano). Esse valor é preocupante $^{184}$, por causa da menor geração de valor, embora a taxa de variação do PIB e a participação do investimento no PIB tenham aumentado em anos recentes. Amitrano et al. (2014), por exemplo, destacam que o período 2004-2008 revelou melhor desempenho em comparação com os anos anteriores a partir de $1995^{185}$. O desempenho do PIB em 2011-2015 (com taxa média de 1,6\%), no entanto, tem sido aquém mesmo do

\footnotetext{
${ }^{184} \mathrm{O}$ debate recente acerca da desindustrialização ou especialização regressiva na economia brasileira tem gerado controvérsia na discussão acadêmica e na formulação de política econômica no Brasil, como se nota em trabalhos como: Oreiro e Feijó (2010), Soares e Teixeira (2011), Squeff (2012) e Bacha e Bolle (2013), Urraca-Ruiz et al. (2013).

${ }^{185}$ Amitrano et al. (2014) utilizaram dados do SCN-Referência 2000, que compreendem o período 1995 2009.
} 
período 1996-2003 (2,0\% de taxa média) e bem abaixo do período 2004-2010 (4,5\% de taxa média), ao mesmo tempo em que ocorre perda mais acentuada na participação da indústria.

Gráfico 17. Participação da indústria de transformação no PIB, preços correntes, 1996-2014.

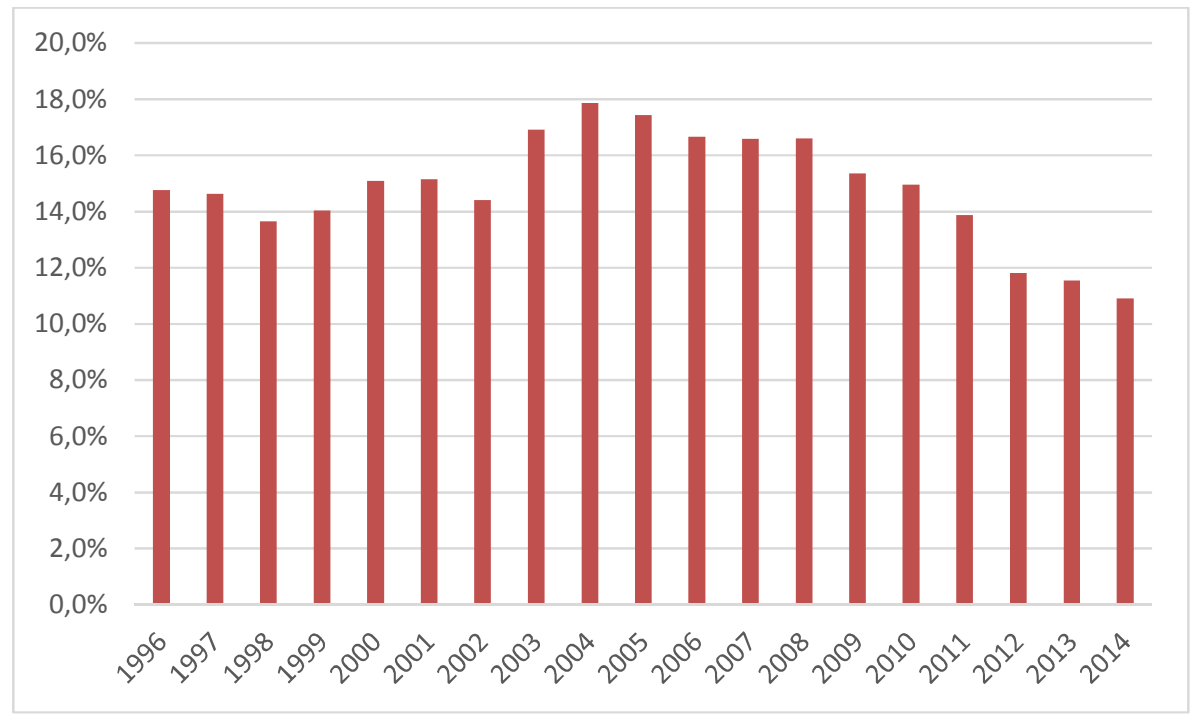

Fonte: SCN/IBGE. Elaboração própria.

Gráfico 18. Taxa de crescimento anual do valor adicionado, série encadeada apreços constantes, 1996-2014.

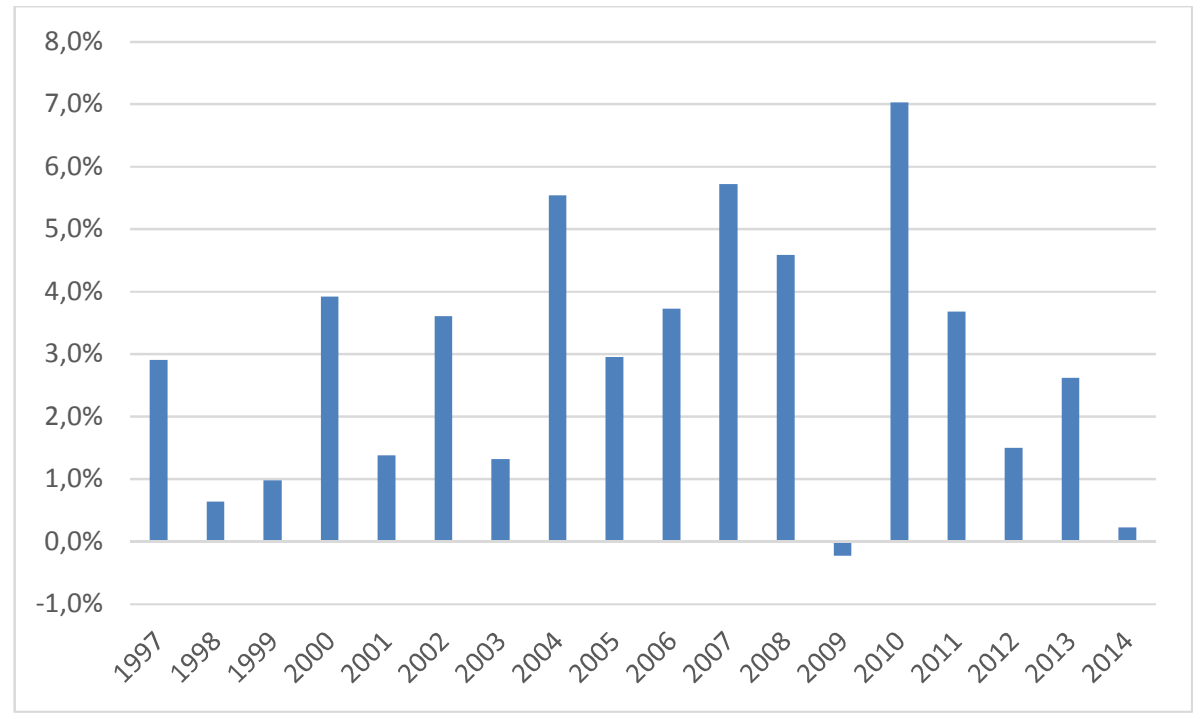

Fonte: SCN/IBGE. Elaboração própria. 
Nesse contexto, alguns dados da Pesquisa Industrial Anual - Empresa (PIAEmpresa), do IBGE, assim como o coeficiente de exportação e de penetração de importações da Funcex, podem auxiliar na compreensão da dinâmica industrial brasileira recente com relação a agregação de valor, rentabilidade, investimentos e gastos com pessoal.

Conforme notado por Sarti e Hiratuka (2010), a indústria de transformação brasileira mostra dificuldades para agregar valor ${ }^{186}$. Essa agregação pode ser medida pela relação entre o valor de transformação industrial e o valor bruto da produção. Enquanto a indústria extrativa revelou nível médio de 64,9\% no indicador, aumentando substantivamente essa relação a partir de 2007 e atingindo quase 76,1\% em 2013, a indústria de transformação manteve-se em patamar próximo de 43,8\% de 1996 a 2013, ainda que apresentasse leve melhora a partir também de 2007, após queda desde 1996.

Gráfico 19. Relação entre valor de transformação industrial e valor bruto da produção, 1996-2013.

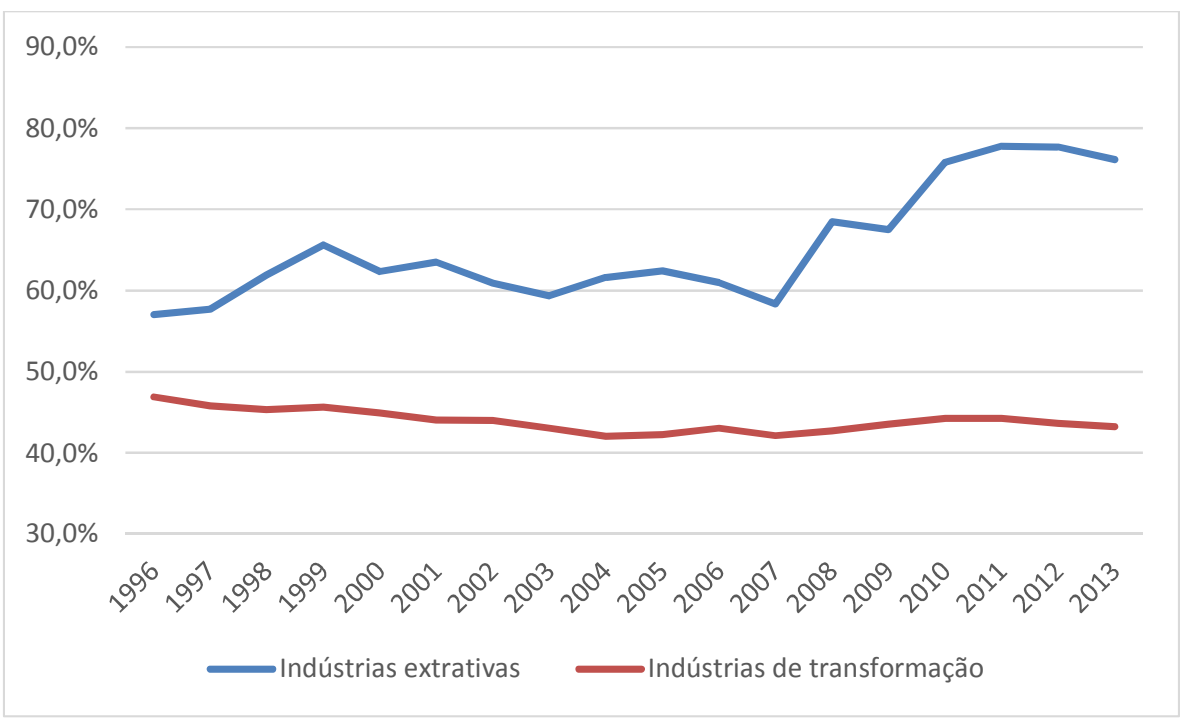

Fonte: PIA-Empresa. Elaboração própria.

Entre os problemas levantados está a perda de adensamento industrial em diversas cadeias, causado por substituição de produção interna por importações, ao mesmo tempo em que a propensão a exportar tem sido insuficiente para dinamizar a indústria como um

\footnotetext{
${ }^{186}$ Ao mesmo tempo são notados diversos estudos sobre a dificuldade no aumento da produtividade recente, como De Negri e Cavalcante (2014), além de piora recente, em 2009-2011, da taxa de inovação no Brasil, após período de crescimento de 1998 a 2008, , de acordo com de dados da Pintec avaliados por De Negri e Cavalcanti (2013).
} 
todo. Como se nota no gráfico abaixo, o coeficiente de penetração de importações, no período 1996-2014, de acordo com dados a preços correntes da Funcex, passou de 14,1\% em 1996 a 20,4\% em 2014, com trajetória que inclui crescimento na década de 1990 até 2001 (18,1\%), valor menos acentuado de 2002 a 2007 e outra forte elevação a partir de então. O coeficiente de exportações, que foi maior em época de câmbio desvalorizado no início da década de 2000 e perdeu força em 2006-2010, voltou a recuperar-se levemente de 2011 a 2014.

Conforme observado com Squeff (2015), com base nas Contas Nacionais, houve significativo aumento das importações no consumo aparente na economia brasileira de 1995 a 2009, o que torna necessárias políticas para mitigar essa situação. Com efeito, Laplane (2015) reconhece que, sem produção industrial local diversificada e competitiva, a elevação do consumo e do investimento poderá ter efeitos negativos sobre as contas externas e restringir o crescimento.

Gráfico 20. Coeficiente de exportação e coeficiente de penetração de importações na indústria de transformação, 1996-2014.

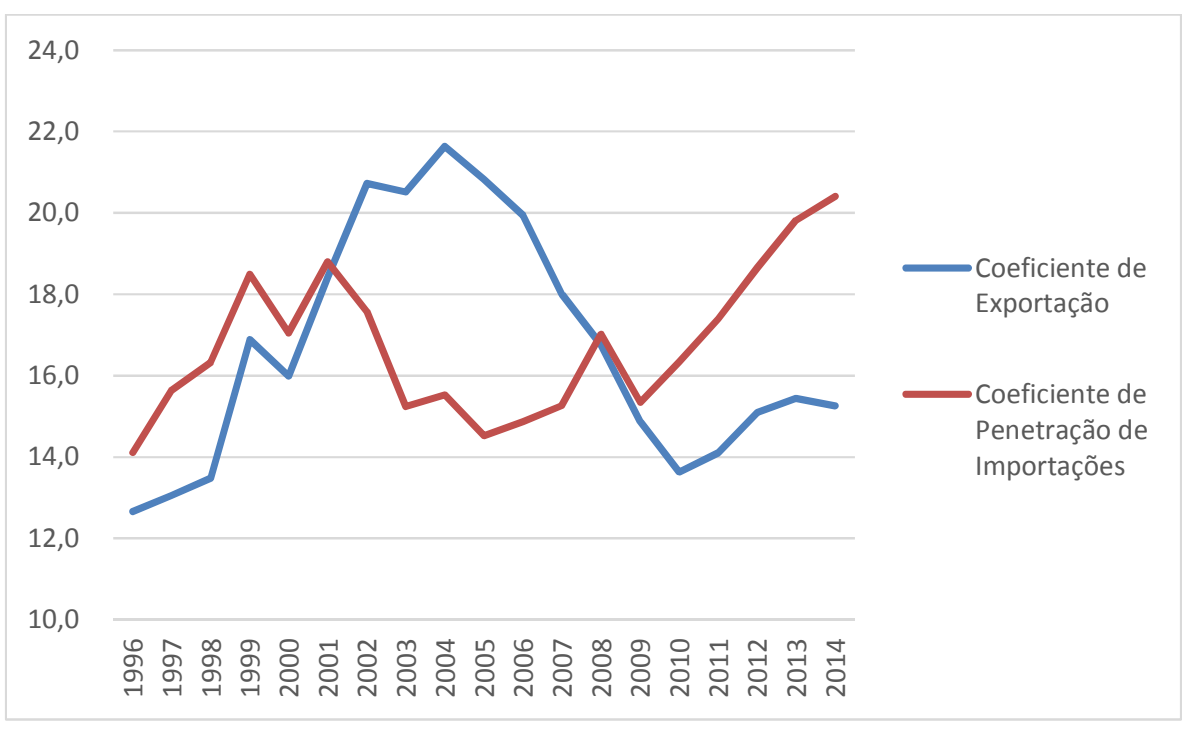

Fonte: Funcex. Elaboração própria.

A evolução da rentabilidade no período recente mostra diferenças entre a indústria de transformação e a extrativa. O lucro foi medido pela diferença entre a receita total e o custo total, e a rentabilidade ou taxa de lucro, pela relação entre lucro e receita total, conforme Sarti e Hiratuka (2010). Nota-se que a taxa de lucro da indústria de 
transformação também é muito reduzida em comparação com a da indústria extrativa, exceto em 2013, quando houve queda acentuada da indústria extrativa. Evidencia-se, com oscilações associadas ao ciclo econômico, trajetória de crescimento do indicador especialmente a partir de 2003, embora haja queda desde 2010. A indústria de transformação elevou o patamar da rentabilidade a partir de 2003, mas mostra queda desde 2009. Essa piora na rentabilidade pode ter efeitos sobre o investimento. A atratividade do setor extrativo e das possibilidades de acumulação nessas atividades foi evidente nos últimos anos.

Gráfico 21. Evolução da rentabilidade das indústrias extrativas e de transformação, 1996-2013.

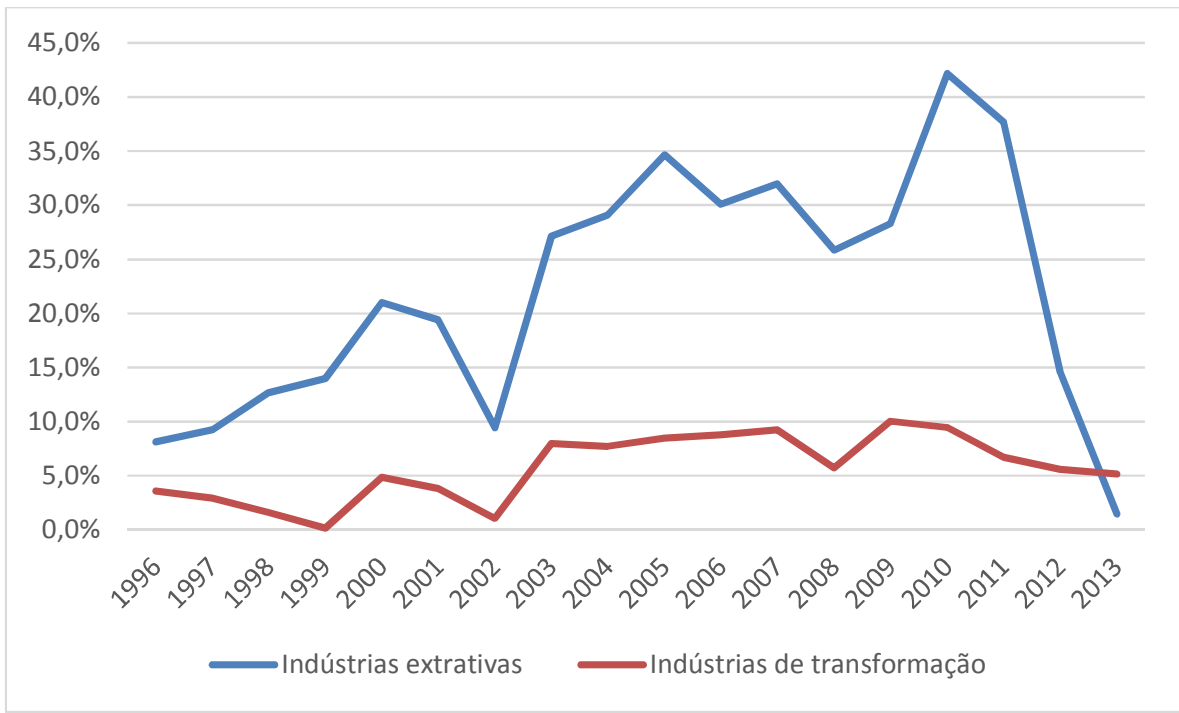

Fonte: PIA-Empresa. Elaboração própria.

Já a evolução da taxa de investimento na indústria de transformação, medida pela relação entre aquisição de ativos imobilizados e valor de transformação industrial, mostra alta a partir de 2007, como havia sido notado por Sarti e Hiratuka (2010), sendo sustentado patamar acima do período 1996-2006. Esse dado parece relacionado com certo aumento do investimento nos últimos anos.

Gráfico 22. Evolução da taxa de investimento na indústria de transformação, 19962013. 


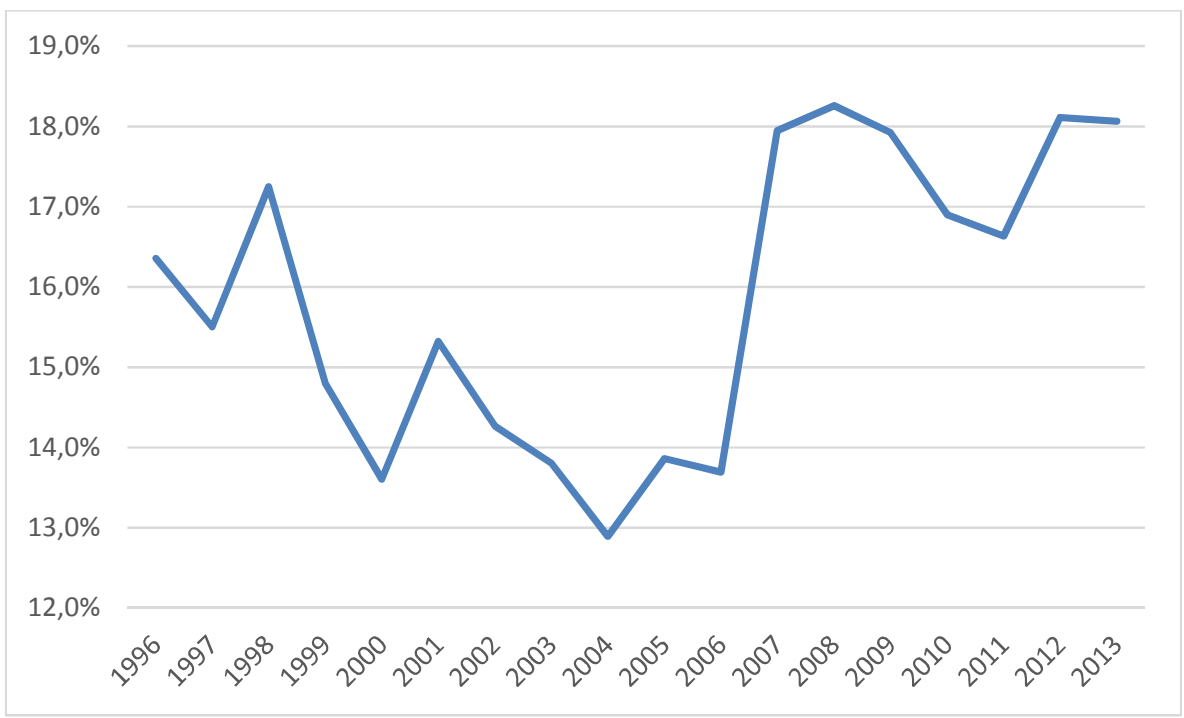

Fonte: PIA-Empresa. Elaboração própria.

A evolução setorial do investimento, medido pela aquisição de ativos imobilizados, revela comportamento importante nas indústrias extrativa e de transformação durante a aceleração dos investimentos em 2007-2013, pelos dados da PIA-Empresa. Nesse período, os maiores ganhos em pontos percentuais foram em fabricação de coque, derivados do petróleo e biocombustíveis (4,8 p.p.), extração de petróleo e gás (4,1 p.p.), extração de minerais metálicos (2,9 p.p.) e fabricação de veículos automotores (1,8 p.p.). Já as maiores perdas foram em metalurgia (-7,6 p.p.), fabricação de produtos alimentícios (-3,1 p.p.) e fabricação de celulose, papel e produtos de papel (1,3 p.p.) e fabricação de produtos químicos (-1,2 p.p.).

Em 2013, apenas a fabricação de coque, de produtos derivados do petróleo e de biocombustíveis correspondeu a 31,0\% do total, sendo seguida de extração de minerais metálicos (10,7\%), fabricação de produtos alimentícios (10,5\%), fabricação de veículos automotores, reboques e carrocerias $(7,8 \%)$ e fabricação de produtos químicos $(4,5 \%)$, extração de petróleo e gás natural e metalurgia (ambos com 4,1\%).

Nota-se que as indústrias extrativas, embora mostrem grande oscilação, em conjunto aumentaram fortemente a participação no total dos investimentos em 20112013, em detrimento da indústria de transformação, após caírem em 2007-2010. Destacaram-se os minerais metálicos e petróleo e gás natural.

Entre os setores cujo desempenho foi mais expressivo no período estão alguns beneficiados pelos preços internacionais, como as commodities minerais. Ainda assim, nota-se que o crescimento em petróleo e gás e coque e derivados está associado ao ciclo 
de investimentos recente, como em virtude da Petrobras e outras empresas. Também o setor automotivo parece associado a políticas recentes, como o regime automotivo. Os setores com perdas estão associados a bens intermediários e podem sinalizar dificuldades quanto à competitividade atual e futura das firmas nessas atividades.

Tabela 4. Participação percentual do investimento nas indústrias de transformação e extrativa, 2007-2013.

\begin{tabular}{|c|c|c|c|c|c|c|c|}
\hline & 2007 & 2008 & 2009 & 2010 & 2011 & 2012 & 2013 \\
\hline Total & 100,0 & 100,0 & 100,0 & 100,0 & 100,0 & 100,0 & 100,0 \\
\hline & $\%$ & $\%$ & $\%$ & $\%$ & $\%$ & $\%$ & $\%$ \\
\hline B Indústrias extrativas & $8,4 \%$ & $5,8 \%$ & $6,2 \%$ & $6,7 \%$ & $11,5 \%$ & $17,2 \%$ & $15,8 \%$ \\
\hline 05 Extração de carvão mineral & $0,1 \%$ & $0,0 \%$ & $0,0 \%$ & $0,0 \%$ & $0,0 \%$ & $0,0 \%$ & $0,0 \%$ \\
\hline 06 Extração de petróleo e gás natural & $0,1 \%$ & $0,0 \%$ & $0,2 \%$ & $0,1 \%$ & $2,2 \%$ & $7,6 \%$ & $4,1 \%$ \\
\hline 07 Extração de minerais metálicos & $7,8 \%$ & $5,1 \%$ & $5,1 \%$ & $5,4 \%$ & $8,1 \%$ & $8,0 \%$ & $10,7 \%$ \\
\hline 08 Extração de minerais não-metálicos & $0,4 \%$ & $0,5 \%$ & $0,6 \%$ & $0,8 \%$ & $0,9 \%$ & $1,2 \%$ & $0,7 \%$ \\
\hline $\begin{array}{l}09 \text { Atividades de apoio à extração de } \\
\text { minerais }\end{array}$ & $0,1 \%$ & $0,1 \%$ & $0,2 \%$ & $0,4 \%$ & $0,3 \%$ & $0,3 \%$ & $0,3 \%$ \\
\hline C Indústrias de transformação & $91,6 \%$ & $94,2 \%$ & $93,8 \%$ & $93,3 \%$ & $88,5 \%$ & $82,8 \%$ & $84,2 \%$ \\
\hline 10 Fabricação de produtos alimentícios & $13,6 \%$ & $12,4 \%$ & $12,2 \%$ & $12,7 \%$ & $12,4 \%$ & $10,6 \%$ & $10,5 \%$ \\
\hline 11 Fabricação de bebidas & $3,3 \%$ & $2,2 \%$ & $2,0 \%$ & $3,2 \%$ & $3,3 \%$ & $2,3 \%$ & $3,4 \%$ \\
\hline 12 Fabricação de produtos do fumo & $0,2 \%$ & $0,3 \%$ & $0,2 \%$ & $0,1 \%$ & $0,2 \%$ & $0,2 \%$ & $0,1 \%$ \\
\hline 13 Fabricação de produtos têxteis & $1,4 \%$ & $1,3 \%$ & $1,2 \%$ & $1,4 \%$ & $1,3 \%$ & $1,0 \%$ & $0,8 \%$ \\
\hline $\begin{array}{l}14 \text { Confecção de artigos do vestuário e } \\
\text { acessórios }\end{array}$ & $0,4 \%$ & $0,5 \%$ & $0,6 \%$ & $0,6 \%$ & $0,6 \%$ & $0,4 \%$ & $0,9 \%$ \\
\hline $\begin{array}{l}15 \text { Preparação de couros e fabricação de } \\
\text { artefatos de couro, artigos para viagem } \\
\text { e calçados }\end{array}$ & $0,6 \%$ & $0,7 \%$ & $0,6 \%$ & $0,5 \%$ & $0,6 \%$ & $0,5 \%$ & $0,5 \%$ \\
\hline 16 Fabricação de produtos de madeira & $1,2 \%$ & $1,5 \%$ & $0,7 \%$ & $0,9 \%$ & $1,2 \%$ & $1,0 \%$ & $0,6 \%$ \\
\hline $\begin{array}{l}17 \text { Fabricação de celulose, papel e } \\
\text { produtos de papel }\end{array}$ & $5,1 \%$ & $5,9 \%$ & $6,0 \%$ & $3,2 \%$ & $2,9 \%$ & $3,1 \%$ & $3,8 \%$ \\
\hline $\begin{array}{l}18 \text { Impressão e reprodução de } \\
\text { gravações }\end{array}$ & $0,7 \%$ & $0,6 \%$ & $0,7 \%$ & $0,8 \%$ & $0,7 \%$ & $0,4 \%$ & $0,3 \%$ \\
\hline $\begin{array}{l}19 \text { Fabricação de coque, de produtos } \\
\text { derivados do petróleo e de } \\
\text { biocombustíveis }\end{array}$ & $26,3 \%$ & $29,3 \%$ & $37,3 \%$ & $34,6 \%$ & $28,8 \%$ & $27,9 \%$ & $31,0 \%$ \\
\hline 20 Fabricação de produtos químicos & $5,7 \%$ & $5,8 \%$ & $4,3 \%$ & $5,6 \%$ & $5,4 \%$ & $4,1 \%$ & $4,5 \%$ \\
\hline $\begin{array}{l}21 \text { Fabricação de produtos } \\
\text { farmoquímicos e farmacêuticos }\end{array}$ & $1,1 \%$ & $1,3 \%$ & $1,0 \%$ & $0,9 \%$ & $1,0 \%$ & $0,8 \%$ & $0,9 \%$ \\
\hline $\begin{array}{l}22 \text { Fabricação de produtos de borracha } \\
\text { e de material plástico }\end{array}$ & $2,9 \%$ & $4,4 \%$ & $2,6 \%$ & $2,8 \%$ & $3,4 \%$ & $3,3 \%$ & $2,5 \%$ \\
\hline $\begin{array}{l}23 \text { Fabricação de produtos de minerais } \\
\text { não-metálicos }\end{array}$ & $2,2 \%$ & $3,3 \%$ & $3,4 \%$ & $3,4 \%$ & $4,2 \%$ & $4,4 \%$ & $3,8 \%$ \\
\hline 24 Metalurgia & $11,7 \%$ & $8,1 \%$ & $5,6 \%$ & $5,9 \%$ & $6,0 \%$ & $5,3 \%$ & $4,1 \%$ \\
\hline $\begin{array}{l}25 \text { Fabricação de produtos de metal, } \\
\text { exceto máquinas e equipamentos }\end{array}$ & $2,1 \%$ & $2,0 \%$ & $1,9 \%$ & $2,4 \%$ & $2,5 \%$ & $1,7 \%$ & $1,8 \%$ \\
\hline $\begin{array}{l}26 \text { Fabricação de equipamentos de } \\
\text { informática, produtos eletrônicos e } \\
\text { ópticos }\end{array}$ & $1,0 \%$ & $1,4 \%$ & $0,9 \%$ & $1,0 \%$ & $1,2 \%$ & $1,0 \%$ & $0,8 \%$ \\
\hline $\begin{array}{l}27 \text { Fabricação de máquinas, aparelhos e } \\
\text { materiais elétricos }\end{array}$ & $1,6 \%$ & $1,3 \%$ & $1,6 \%$ & $1,4 \%$ & $1,5 \%$ & $1,3 \%$ & $1,2 \%$ \\
\hline
\end{tabular}




\begin{tabular}{|c|c|c|c|c|c|c|c|}
\hline $\begin{array}{l}28 \text { Fabricação de máquinas e } \\
\text { equipamentos }\end{array}$ & $2,2 \%$ & $2,7 \%$ & $2,1 \%$ & $2,7 \%$ & $2,4 \%$ & $2,5 \%$ & $2,4 \%$ \\
\hline $\begin{array}{l}29 \text { Fabricação de veículos automotores, } \\
\text { reboques e carrocerias }\end{array}$ & $6,0 \%$ & $6,4 \%$ & $6,1 \%$ & $4,9 \%$ & $6,6 \%$ & $7,9 \%$ & $7,8 \%$ \\
\hline $\begin{array}{l}30 \text { Fabricação de outros equipamentos } \\
\text { de transporte, exceto veículos } \\
\text { automotores }\end{array}$ & $1,0 \%$ & $1,7 \%$ & $1,3 \%$ & $2,4 \%$ & $0,7 \%$ & $1,5 \%$ & $1,1 \%$ \\
\hline 31 Fabricação de móveis & $0,6 \%$ & $0,5 \%$ & $0,5 \%$ & $0,6 \%$ & $0,7 \%$ & $0,6 \%$ & $0,6 \%$ \\
\hline 32 Fabricação de produtos diversos & $0,5 \%$ & $0,4 \%$ & $0,4 \%$ & $0,6 \%$ & $0,4 \%$ & $0,5 \%$ & $0,4 \%$ \\
\hline $\begin{array}{l}33 \text { Manutenção, reparação e instalação } \\
\text { de máquinas e equipamentos }\end{array}$ & $0,2 \%$ & $0,2 \%$ & $0,3 \%$ & $0,4 \%$ & $0,4 \%$ & $0,3 \%$ & $0,3 \%$ \\
\hline
\end{tabular}

Fonte: PIA-Empresa. Elaboração própria.

Ainda que se verifique aumento dos salários na economia brasileira, os gastos com pessoal descrevem trajetória que não parece pressionar significativamente os custos das firmas. Esses gastos tiveram queda como proporção dos custos totais ao longo do período 1996-2002, passando de 19,3\% para 11,5\%. Esse resultado está associado a estratégias das firmas para redução de custos, racionalização e terceirização, além de redução dos salários reais, como notam, por exemplo, Sarti e Hiratuka (2010). Com aumento do crescimento econômico e dos salários reais, esses custos recuperaram um pouco de participação até 2010 (14,4\%), mantendo esse patamar até 2013 (14,1\%).

Os custos de mão de obra têm sido objeto de debate quanto à competitividade da indústria brasileira, principalmente com relação à medida de custos unitários do trabalho. Ainda que diversos autores argumentem que os aumentos dos custos de mão de obra têm impactado negativamente a competitividade da indústria ${ }^{187}$, esses gastos não têm aumentado significativamente como proporção do custo total até 2013 e ainda estão abaixo do nível de 1996.

Gráfico 23. Gastos de pessoal como proporção dos custos e despesas totais, 1996-2013.

187 Como, por exemplo, salienta Souza (2015). Para Pastore et al. (2013), na base da estagnação da produção industrial a partir de 2010 está a elevação do custo unitário do trabalho. No debate novo desenvolvimentista, o aumento excessivo de salários também é visto como questão essencial na competitividade. 


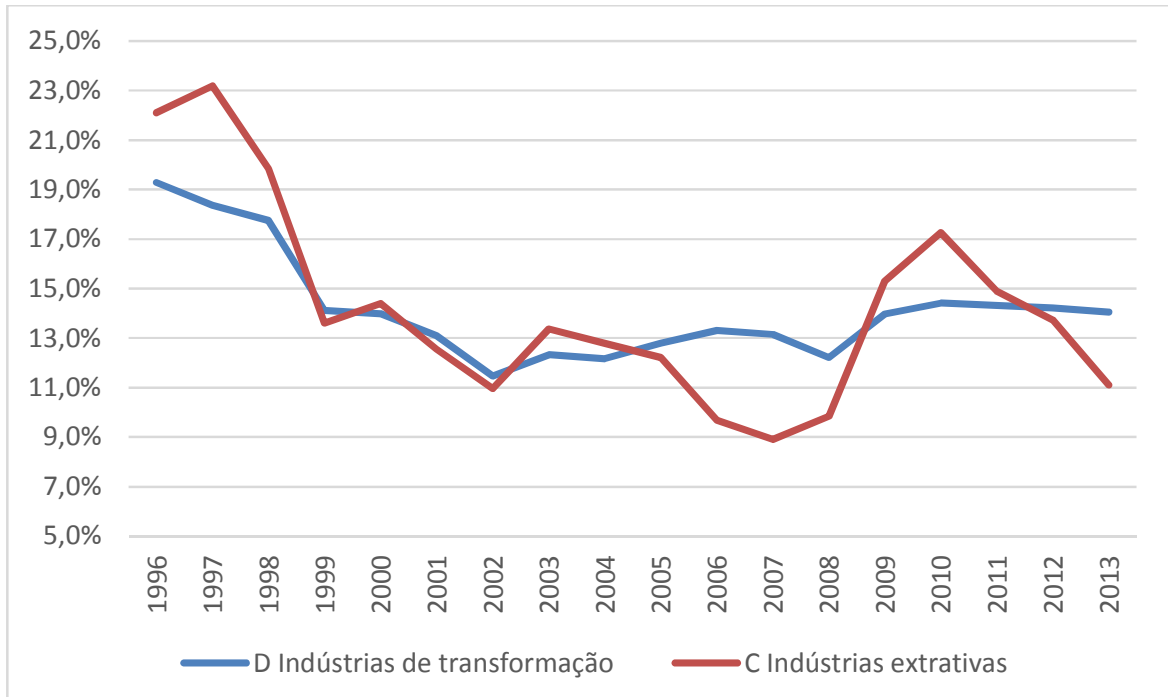

Fonte: PIA-Empresa. Elaboração própria.

Uma comparação internacional permite que se faça observação do contexto dos salários na manufatura brasileira frente a outros países competidores. De acordo com os dados do Conference Board ${ }^{188}$, pode ser notado, no gráfico abaixo, o índice de custos de compensações (salários diretos e indiretos, como previdência social) da mão de obra por hora como percentual dos custos dos EUA em alguns países.

O Brasil, de 1996 a 2002, mostrou redução significativa desses custos com mão de obra, ao cair de 31\% para 11\% do equivalente pago nos EUA. Já entre 2004 e 2011 houve recomposição desses custos no Brasil (até atingir 33\%). Ocorreu redução em 2012 e 2013, fazendo com que, no último ano disponível, o patamar brasileiro se encontrasse próximo ao que foi registrado durante meados da década de 1990. No período 1996-2013, economias como Taiwan mostraram redução (32\% para 26\%), mas México e Coreia do Sul tiveram aumentos (respectivamente, de $14 \%$ para $19 \%$ e de $40 \%$ para $60 \%$ ). Os dados disponíveis para China, embora a Conference Board reconheça falta de comparabilidade para este país, mostram que a economia foi de $2 \%$ para $9 \%$ dos custos dos EUA entre 2002 e 2012.

Gráfico 24. Índice de custos de compensações (salários diretos e indiretos) da mão de obra por hora como percentual dos custos dos EUA, países selecionados, 1996-2013.

${ }^{188}$ Essa instituição passou a atualizar os dados de hourly compensation costs que eram compilados pelo Bureau of Labor Statistics, do governo dos EUA. 


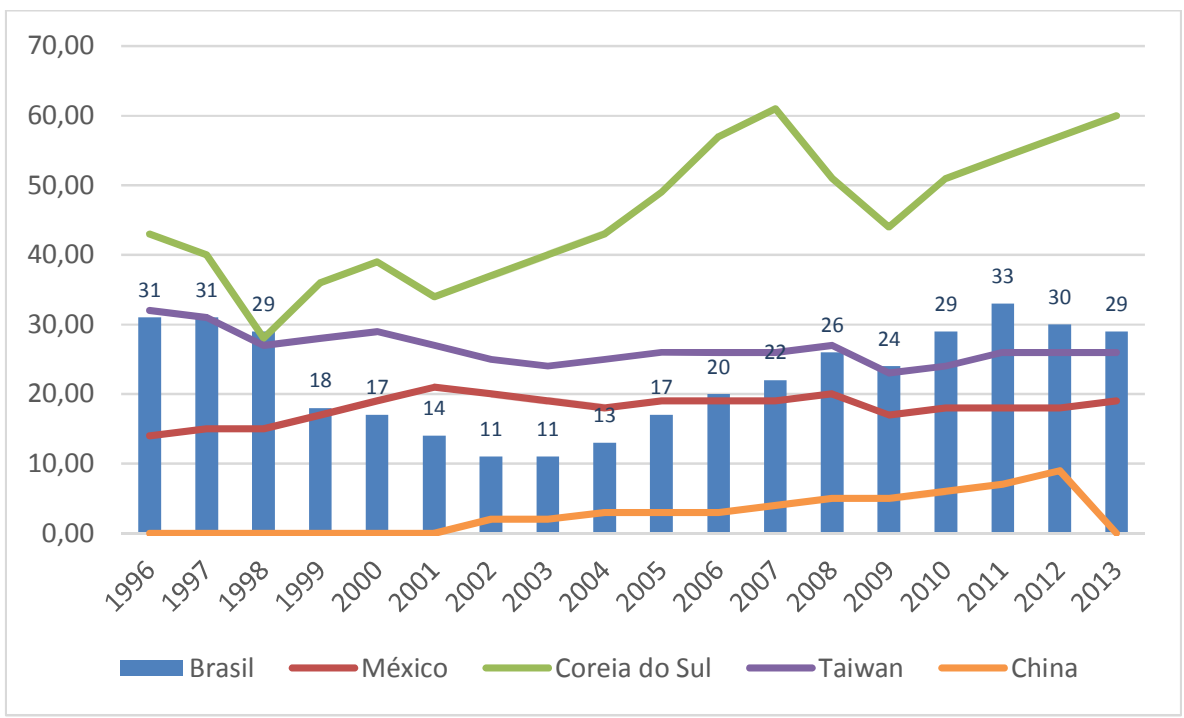

Fonte: The Conference Board. Elaboração própria.

Dessa forma, apesar de aumento no crescimento econômico em 2004-2010 e mesmo de investimentos, alguns problemas da indústria de transformação permanecem, como a baixa agregação de valor e o aumento do consumo aparente de importados, o que pode estar associado a piora no adensamento industrial de diversas cadeias. Também alguns custos relativos a mão de obra podem ser ponderados, uma vez que têm mostrado pressão recente frente ao período de racionalização e enxugamento da década de 1990, sem ultrapassar os níveis anteriores.

\subsection{Políticas de desenvolvimento produtivo para a economia brasileira}

A retomada das políticas industriais, em suas diversas formas de efetivação, constituiu medida importante para o desenvolvimento produtivo e tentativa de retomada da industrialização no Brasil, em conjunto com a expansão do consumo de massas, da produção e do investimento. As preocupações com a formação de competências, as parcerias público-privadas, o estímulo à consolidação de empresas públicas e privadas competitivas internacionalmente, o adensamento produtivo, a agregação de valor, o fortalecimento de elos locais das cadeias de valor e a diversificação produtiva, entre outras, são elementos das políticas contemporâneas relevantes para o desenvolvimento econômico e social. 
As políticas recentes no Brasil podem ter progredido em um sentido mais próximo ao de Keynes, com medidas de aumento do investimento público, principalmente pela coordenação público-privada e estratégias de atuação em determinados setores chaves, e ao dos desenvolvimentistas sociais e marxistas, da expansão do consumo de massas com políticas de transferência de rendas e redução da desigualdade. As formas de governança e o aprendizado institucional a partir das três últimas políticas industriais implementadas constituem avanço recente. O aproveitamento dessas características deve ser importante na formulação de novas políticas para o desenvolvimento produtivo e a inovação.

Mesmo que tenha havido melhora em alguns aspectos do desempenho econômico, a fragilização da indústria brasileira parece requerer mais medidas para aproximar-se do padrão de concorrência internacional e melhorar a inserção da economia brasileira no comércio exterior. A taxa de investimento, se bem que tenha observado elevação em meados da década de 2000, ainda está distante do histórico de desenvolvimento na economia brasileira, salienta Sarti (2015). Assim, são necessários mais investimentos, em especial nos principais vetores para o aumento da demanda da indústria, como a infraestrutura ${ }^{189}$.

A formulação das políticas deve considerar os efeitos obtidos. Os estímulos recentes voltados para redução de custos e tributos para o setor privado podem não ter sido suficientes para sustentar a demanda por investimento e bens produzidos localmente, mesmo que possam ter sido relevantes para os lucros na indústria. Como se nota na perspectiva keynesiana, os estímulos ao investimento privado, em razão das expectativas, podem não desencadear aumento correspondente nesse gasto por parte das firmas. As estratégias de expansão do investimento público e o caráter empreendedor do Estado na criação de mercados e na inovação junto ao setor privado podem ser mais eficazes para o objetivo de melhorar a competitividade e promover mudanças estruturais.

Ademais, a preocupação com posturas defensivas por parte das firmas deve ser constante, para que recursos e instrumentos não sejam desperdiçados e a racionalização de custos não tenha resultados negativos sobre o emprego. Os custos com mão de obra, certamente relevantes para as firmas, podem não ser o maior problema da competitividade. Uma redução do nível de emprego e de salários reais não é desejável na medida em que piora a distribuição de renda e o consumo.

189 Para Sarti (2015), a expansão das exportações é dificultada pela perda de competitividade sistêmica brasileira e o acirramento da concorrência internacional, principalmente dos asiáticos. Nesse contexto, a desvalorização cambial pode ser insuficiente para melhorar a competitividade. 
Apesar de justificativas apropriadas para a formulação e a execução das políticas industriais recentes, as críticas às políticas industriais no Brasil tornaram-se maiores com a piora do desempenho econômico a partir de 2011. Para Laplane (2015), como as medidas anticíclicas, a partir daquele ano, não conseguiram restaurar expectativas de crescimento ou estimular a produção e os investimentos, a capacidade da política industrial de induzir mudanças estruturais ficou fragilizada. Em meio a esse contexto, são recorrentes as críticas a supostos intervencionismos erráticos, escolha de campeões nacionais e protecionismo na condução das políticas.

Entre outras críticas, Almeida (2013), por exemplo, desaprova a política recente pelo fato de não estar próxima à visão atual de política industrial relacionada aos custos de descobrimento ${ }^{190}$, e de tentar reproduzir a política antiga desenvolvida pelos tigres asiáticos. A política brasileira teria sido muito voltada para grandes grupos em setores e atividades já existentes e que já conhecem seus custos e podem pegar empréstimos no exterior, sem a ajuda do BNDES.

Parecem existir pressões para maior abertura, concorrência e autorregulação dos mercados na estratégia de desenvolvimento. Laplane (2015) explica que medidas supostamente de reindustrialização têm utilizado receituário como o da década de 1990, de desregulação e abertura (para aumento da concorrência, produtividade, eficiência e inovação). Essas ações engendrariam forte desindustrialização no Brasi1 ${ }^{191}$, por causa da concentração na indústria global e dos níveis de competitividade externa necessários para enfrentar a concorrência.

Em 2015, parece existir percepção nos ministérios associados ao desenvolvimento industrial de que é necessária maior integração nas cadeias produtivas globais. Essa inserção deve ser acompanhada de maiores exportações e importações, por meio de instrumentos de facilitação do comércio, além de medidas de financiamento e garantias às exportações. Recentemente lançado, o Plano Nacional de Exportações (2015) ${ }^{192}$, fornece diagnóstico de que há baixa integração a cadeias globais de valor e que as exportações brasileiras utilizam poucos insumos importados. Entre as medidas anunciadas, pode ser destacada a redução do tempo médio de liberação de licenças de

\footnotetext{
${ }^{190}$ Vinculada à perspectiva ortodoxa discutida no capítulo 3.

${ }^{191}$ Parece voltar o argumento de laissez-faire na condução da política econômica, com efeitos dinâmicos deletérios para a estrutura produtiva.

${ }^{192} \mathrm{Na}$ concepção da governança são consideradas centrais a Câmara de Comércio Exterior (Camex), do lado do governo, enquanto se busca participação diretiva do setor privado na implementação e acompanhamento, por meio do Conselho Nacional de Desenvolvimento Industrial (CNDI) e o Conselho Consultivo do Setor Privado (Conex).
} 
importação, assim como a criação de instrumentos administrativos e a assinatura de acordos para facilitar exportações e importações.

Já o discurso das entidades empresariais parece associado a demandas voltadas principalmente a políticas de desoneração tributária, incentivos fiscais, flexibilização trabalhista e financiamento. A CNI (2014) apresenta medidas de política industrial que incluem políticas de conteúdo local e utilização de compras públicas, bem como regimes tributários especiais. Está presente a noção de adensamento das cadeias produtivas. Entre os custos, um dos principais apontados é o da mão de obra, para o qual são dirigidas propostas de modernização da legislação trabalhista, como flexibilização de contratações e terceirização.

A Mobilização Empresarial pela Inovação (MEI, 2014), também ligada à CNI, destaca diversas medidas. Estão presentes: atração de centros de P,D\&I, margens de preferência em compras públicas relativas a inovação; desenvolvimento de estratégias de longo prazo para inserção internacional das empresas brasileiras em cadeias globais de valor (com substituição de importações, organizadas a partir de grandes projetos), mas também pretende desonerar importações como as de serviços, além de obter maiores benefícios fiscais, subvenções e financiamento para inovação.

A Associação Brasileira da Indústria de Máquinas e Equipamentos (Abimaq) talvez tenha maior interesse no aumento direto dos investimentos na economia. Significativa representante do setor, embora tenha perdido poder desde a abertura comercial na década de $1990^{193}$, a Abimaq apresenta propostas que situam a produção nacional como prioridade, bem como revelam preocupação com o perfil importador dos regimes especiais criados recentemente ${ }^{194}$.

Talvez precise haver avanço, na formulação de políticas industriais, com relação à definição dos objetivos de longo prazo da sociedade e a articulação entre agentes públicos e privados, no sentido da retomada da industrialização e do investimento. Essa coordenação não é simples por causa dos interesses conflitantes na sociedade e, como aponta Laplane (2015), da heterogeneidade estrutural da indústria.

A articulação entre setor público e privado deve levar a sinergia entre as duas esferas. A capacidade estatal de criar mercados e inovar deve incentivar também posturas

\footnotetext{
193 Principalmente diante do aumento das importações. Dados da Abimaq (2014) sinalizam quadro crítico de aumento do consumo aparente de máquinas e equipamentos importados. Ante uma situação de equilíbrio entre importados e de bens produzidos localmente em 2008, o ano de 2014 fechou com $71 \%$ de consumo de máquinas e equipamentos importados.

${ }^{194}$ Entre os quais o regime aduaneiro especial para petróleo e gás, Repetro.
} 
mais audaciosas e arriscadas dos empresários, em especial no desenvolvimento de projetos específicos de grande porte ${ }^{195}$. A participação dos trabalhadores também pode ser importante para maior coordenação e definição dos objetivos de longo prazo na sociedade.

Também a coordenação no governo é imprescindível, para que não haja conflitos de política econômica. Os pós-keynesianos enfatizam a convergência das políticas econômicas. As políticas industriais, devem ser pensadas de maneira sistêmica e coordenada com a estratégia de desenvolvimentismo social e outras políticas, sem estar subordinada à política macroeconômica. De acordo com Kupfer e Laplane (2010, p. 317):

No âmbito da escolha da estratégia de desenvolvimento industrial como motor do crescimento econômico no Brasil não faz sentido subordinar as políticas estruturantes às políticas macroeconômicas recessivas e equivocadas de juros altos e câmbio valorizado. A coordenação da expansão da demanda (consumo e investimento) com o incremento da eficiência e capacidade produtivas constituem a política mais eficaz e socialmente justa de acumulação de capital, de controle inflacionário, de aumento real de poder aquisitivo e de distribuição de renda.

Entre essas diversas formas de coordenação pode ser desenvolvida certa coalizão desenvolvimentista. Alguns autores, como Bresser-Pereira (2015), defendem uma coalizão desenvolvimentista, em especial na administração de um câmbio desvalorizado. É possível pensar em pontos em comum ou convergentes relacionados a investimentos na indústria e em infraestrutura, para aumento da demanda por bens industriais produzidos internamente, além do desenvolvimento de capacidades, inovação e internacionalização de empresas brasileiras, mantendo a inclusão social e melhorando a distribuição de renda.

\footnotetext{
195 Conforme discutido no capítulo 3, esses projetos têm capacidade de alavancar investimentos. Laplane (2015b) avalia que a identificação de áreas promissoras para o desenvolvimento tecnológico está associada ao desafio de formular políticas adequadas às oportunidades econômicas e tecnológicas. $\mathrm{O}$ financiamento público de projetos de inovação arriscados e caros demanda avaliação cuidadosa do potencial tecnológico, econômico e dos benefícios em bem-estar, assim como equilíbrio entre riscos e benefícios públicos e privados e arranjos institucionais de monitoramento dos projetos.
} 


\section{Comentários finais}

Os temas tratados nesta Tese estão relacionados a diversos aspectos do desenvolvimento produtivo, em especial no desenvolvimento produtivo no Brasil contemporâneo. Diversas contribuições heterodoxas podem auxiliar na compreensão de aspectos importantes dos desafios ao desenvolvimento produtivo recente na economia brasileira.

No capítulo 1, foram discutidos fundamentos macroeconômicos em Marx e Keynes e como esses autores trazem contribuições à heterodoxia e permitem compreensão mais ampla da complexidade existente no capitalismo. Os fundamentos microeconômicos usuais na abordagem ortodoxa podem ser contestados com base em argumentos presentes até na escola neoclássica. Os conceitos e a formulação teórica trazidos por Marx e Keynes elucidam aspectos essenciais do sistema capitalista que tornam necessário o entendimento de fundamentos macroeconômicos para $o$ comportamento microeconômico. Marxistas e pós-keynesianos definem o papel e o comportamento dos agentes econômicos a partir de um contexto macro, respectivamente, quanto à evolução capitalista fundada na lei do valor ou pela incerteza que permeia as decisões econômicas em economias monetárias. As noções avançadas por Marx e Keynes são úteis ao entendimento das limitações ao desenvolvimento econômico no capitalismo e à avaliação das políticas econômicas conducentes ao crescimento ou que mitiguem os efeitos da instabilidade e da desigualdade inerentes ao sistema. As duas correntes heterodoxas reconhecem possibilidades de atuação concreta do Estado no desenvolvimento, em particular para agir sobre o contexto macroeconômico que afeta o comportamento dos agentes.

No capítulo 2, foram discutidos alguns fundamentos da firma e do investimento em Marx e Keynes que são importantes para construir interpretação alternativa à visão dominante da nova economia institucional. O objetivo do lucro e a necessidade de acumulação ou investimento são características precípuas das firmas, que são constituídas por competências específicas em meio a uma realidade não ergódica e à concorrência no processo de acumulação. Uma a dinâmica setorial associada intrinsecamente à indústria quanto ao crescimento e o investimento pode ser verificada em Marx e Keynes. Enquanto os animal spirits dos trabalhadores são despertados pela cooperação que se 
torna mais ampla na indústria, explica Marx, os animal spirits dos empresários são imprescindíveis para a tomada de ação quanto ao investimento na economia, evidencia Keynes.

Podem ser complementares para o entendimento de aspectos do comportamento das firmas e do investimento e das perspectivas setoriais na economia as abordagens de Marx e Keynes e contribuições posteriores com base nos dois autores. A ação estratégica das firmas e o papel do investimento são importantes. O investimento em bens de capital tem caráter complexo no nível da firma, ao estar associado à incerteza sobre o valor ou o rendimento futuro desses bens, bem como ao caráter geralmente ilíquido dos bens de capital. Os elementos teóricos definidos por Marx e Keynes das economias capitalistas destacam a importância da complexidade e da instabilidade.

A concorrência e o capitalismo de laissez-faire podem ser criticados e suscitar intervenções estatais para diminuir os custos associados à dinâmica capitalista, embora as limitações da atuação governamental sejam importantes também no capitalismo. Tanto para Marx quanto para Keynes a interação entre produção e o sistema financeiro são fundamentais para a economia capitalista. Por fim, a indústria de transformação pode ser vista como importante em perspectivas originadas nos dois autores. A indústria apresenta características relacionadas com o aprendizado e a disseminação do progresso técnico que a tornam importante para o crescimento de toda a economia, como se nota na tradição kaldoriana, mas também em Marx, para quem a geração de valor pode ter aspectos setoriais significativos.

No capítulo 3, foram discutidas diferentes perspectivas sobre política industrial, com ênfase nas abordagens heterodoxas. Ainda que exista preocupação maior da economia mainstream na diversificação produtiva e na mudança estrutural, as contribuições teóricas ainda estão fundadas em hipóteses restritivas do comportamento econômico e partem teoricamente da intervenção estatal como uma exceção ao mecanismo de mercado. A identificação de falhas de mercado frente a mercado perfeito justifica a atuação governamental, por mais pervasivas que sejam essas falhas e ainda que sejam entendidas como políticas second best.

Contribuições heterodoxas são consideradas. A evolução das ideias cepalinas ou do estruturalismo latino-americano indica as dificuldades associadas à desigualdade na economia mundial e à estrutura produtiva heterogênea das economias periféricas, assim como a necessidade de os governos agirem para quebrar ciclo de subdesenvolvimento econômico e social de acordo com objetivos sociais. Foi verificada convergência entre 
neoestrutralismo e a escola schumpeteriana ou evolucionária, que traz noções importantes para a atuação governamental na mudança estrutural, em especial quanto ao papel da inovação. Outras contribuições que parecem destacar-se recentemente admitem a necessidade da atuação empreendedora do Estado, na criação de mercados e modificação de estruturas econômicas.

As contribuições de Marx e Keynes podem somar-se à literatura existente sobre políticas de desenvolvimento produtivo e servir de base para o debate brasileiro. A intervenção estatal decorrente da visão de Marx está associada à complexidade do capitalismo e à autonomia relativa do Estado. Existe autonomia relativa que permite a possibilidade de pressões por melhorias na relação capital-trabalho e na regulamentação econômica. As políticas keynesianas como têm sido apresentadas em geral podem ser representantes mais restritas da visão de Keynes sobre a atuação estatal. A distribuição de renda e a forma de intervenção, que implica estímulos ao setor privado até o momento em que houver aumento do investimento das empresas, podem ser interpretadas como centrais na perspectiva de Keynes de políticas de longo prazo, como a socialização do investimento. Diversas políticas podem ser derivadas da concepção de Keynes, entre as quais a necessidade do investimento público em formas variadas, como no direcionamento dos recursos na economia. Para Marx e Keynes, o sistema capitalista é inerentemente defectível. Ainda assim, cabe notar que existem limites à ação estatal, em especial nas crises, mas também no estímulo ao investimento privado.

A discussão sobre as correntes de desenvolvimentismo no Brasil tem considerações teóricas e de política econômica importantes, a partir de classificação feita entre as correntes heterodoxas. São discutidos o novo-desenvolvimentismo, o novodesenvolvimentismo pós-keynesiano e o social desenvolvimentismo, que mostra perspectivas mais apropriadas ao desenvolvimento no Brasil. Outras noções de Marx e Keynes podem ser trazidas ao debate. As perspectivas heterodoxas possibilitam justificativa teórica ampla para a ação governamental. Se houver preocupação com o pleno emprego e condições melhores no processo de trabalho, o investimento e a acumulação parecem constituir objetivo de política de desenvolvimento produtivo mais apropriado ao desenvolvimento econômico e social para a caso brasileiro, com maior relevância para a indústria e setores líderes na acumulação de capital e de competências na economia.

No capítulo 4, foram discutidos elementos da economia brasileira recente e de políticas de políticas de desenvolvimento produtivo. A inserção internacional da 
economia brasileira mostra desafios. $\mathrm{O}$ desempenho brasileiro tem sido ruim na indústria mundial, com reflexos sobre a vulnerabilidade externa. O saldo comercial brasileiro, muito influenciado por preços, tem mostrado piora recente. A composição da pauta comercial indica regressão quanto a setores importantes e setores de mais alto nível tecnológico.

O desenvolvimento produtivo brasileiro recente tem como herança o contexto de industrialização e das políticas adotadas, de acordo com perspectivas heterodoxas estudadas. A industrialização passou a enfrentar problemas nas décadas de 1980 e 1990, por causa de instabilidade macroeconômica e abertura. Nota-se, no entanto, mudança em meados da década de 2000, em direção a políticas com maior participação estatal e desenvolvimento com inclusão social. A atuação do investimento público tem sido fundamental para aumentar o investimento e o crescimento na economia. Alguns aspectos da dinâmica recente da indústria no Brasil foram notados. Apesar de aumento no crescimento econômico em 2004-2010 e mesmo de investimentos, alguns problemas da indústria de transformação permanecem, como a baixa agregação de valor e o aumento do consumo aparente de importados, o que pode estar associado a piora no adensamento industrial de diversas cadeias. Houve certo aumento da rentabilidade na indústria de transformação. Também alguns custos relativos a mão de obra podem ser ponderados, uma vez que têm mostrado pressão recente frente ao período de racionalização e enxugamento da década de 1990, sem ultrapassar níveis anteriores.

Por fim, notou-se que a retomada das políticas industriais, em suas diversas formas de efetivação, constituiu medida importante para o desenvolvimento produtivo e tentativa de reindustrialização no Brasil, em conjunto com a expansão do consumo de massas, da produção e do investimento. As preocupações com a formação de competências, as parcerias público-privadas, o estímulo à consolidação de empresas públicas e privadas competitivas internacionalmente, o adensamento produtivo, a agregação de valor, o fortalecimento de elos locais das cadeias de valor e a diversificação produtiva, entre outras, são elementos das políticas contemporâneas relevantes para o desenvolvimento econômico e social.

As políticas recentes no Brasil podem ter progredido, ainda que timidamente, em um sentido mais próximo ao de Keynes, com medidas de aumento do investimento público, principalmente pela coordenação público-privada e estratégias de atuação em determinados setores chaves, bem como em sentido próximo ao de alguns marxistas e dos desenvolvimentistas sociais, pela expansão do consumo de massas com políticas de 
transferência de rendas e redução da desigualdade. As formas de governança e o aprendizado institucional a partir das três últimas políticas industriais implementadas constituem também avanço recente.

Mesmo que tenha havido melhora em alguns aspectos do desempenho econômico, a fragilização da indústria brasileira parece requerer mais medidas para aproximar-se do padrão de concorrência internacional e melhorar a inserção da economia brasileira no comércio exterior. A piora setorial e tecnológica nas relações comerciais internacionais é motivo também de preocupação quanto aos aspectos dinâmicos do desenvolvimento recente. A taxa de investimento, se bem que tenha observado elevação em meados da década de 2000, ainda está distante do histórico da economia brasileira.

Os estímulos recentes voltados para a redução de custos e tributos para o setor privado podem não ter sido suficientes para sustentar a demanda por investimento e bens produzidos localmente, mesmo que possam ter sido relevantes para os lucros na indústria. Como se nota na perspectiva keynesiana, os estímulos ao investimento privado, em razão das expectativas, podem não desencadear aumento correspondente nesse gasto por parte das firmas. As estratégias de expansão do investimento público e o caráter empreendedor do Estado na criação de mercados e na inovação junto ao setor privado podem ser mais eficazes para o objetivo de melhorar a competitividade e promover mudanças estruturais.

Precisa haver avanço, na formulação de políticas industriais, com relação à definição dos objetivos de longo prazo da sociedade e a articulação entre agentes públicos e privados, no sentido da retomada da industrialização e do investimento. Essa coordenação não é simples por causa dos interesses conflitantes na sociedade e da heterogeneidade estrutural da indústria. A capacidade estatal de criar mercados e inovar deve incentivar também posturas mais audaciosas e arriscadas dos empresários, em especial no desenvolvimento de projetos específicos de grande porte. A participação dos trabalhadores também pode ser importante para maior coordenação e definição dos objetivos de longo prazo na sociedade. Também a coordenação no governo é imprescindível, para que não haja conflitos de política econômica. Os pós-keynesianos enfatizam a convergência das políticas econômicas. As políticas industriais devem ser pensadas de maneira sistêmica e coordenada com a estratégia de desenvolvimentismo social e outras políticas, sem estarem subordinadas à política macroeconômica.

Os conflitos entre interesses individuais e coletivos devem ser tratados para a definição de objetivos sociais no processo de desenvolvimento. A oposição entre Estado e mercado não se justifica em diversas contribuições teóricas e na história, inclusive 
recente, dos processos de industrialização e mudança estrutural. O Estado, ainda que não esteja isento de conflitos em sua atuação, pode ser direcionado, na sua intervenção econômica, para objetivos mais apropriados do ponto de vista social e para a melhoria da capacidade de geração de valor e de inovação na produção interna e nas relações da economia brasileira com a economia mundial. É possível pensar em coalizões desenvolvimentistas com pontos em comum ou convergentes relacionados a investimentos na indústria e em infraestrutura, para aumento da demanda por bens industriais produzidos internamente, além do desenvolvimento de capacidades, inovação e internacionalização de empresas brasileiras, mantendo-se a inclusão social e melhorando a distribuição de renda. 


\section{Apêndice. Mudanças recentes na metodologia das Contas Nacionais no Brasil}

As mudanças entre o SCN-2000 e SCN-2010 são significativas. Segundo o IBGE (2015), entre as distinções estão: modificação da classificação de ativos fixos que compõem a formação bruta de capital fixo, com a inclusão da produção de $\mathrm{P} \& \mathrm{D}$ e da produção de exploração mineral; tratamento diferenciado das sedes de empresas; tratamento das usinas termelétricas na atividade energia elétrica; reclassificação de atividades, com adoção da CNAE 2.0, que é compatível com a classificação internacional ISIC/CIIU Rev. $4^{196}$.

No caso da indústria geral, houve modificações conceituais que geraram queda estimada de 0,7 p.p. na participação no valor adicionado bruto, apesar da inclusão da estimativa de investimento na exploração de reservas e construção de poços de petróleo pelas empresas da atividade Extrativa mineral e da inclusão da produção de P\&D pela indústria. A reconsideração das atividades realizadas pelas unidades-sede implicou transferência para o setor de Outros serviços de unidades administrativas de empresas industriais. A adoção da CNAE 2.0 gerou reclassificação no setor de Edição, impressão e reprodução, cuja produção considerada como industrial foi fortemente reduzida, em benefício também dos serviços.

Tabela 5. Diferenças na composição setorial entre o SCN-2010 e o SCN-2000, por atividades, 2010.

\begin{tabular}{|l|r|r|r|r|r|}
\hline \multirow{2}{*}{\multicolumn{1}{|c|}{ Atividades }} & \multicolumn{5}{|c|}{ Valor adicionado bruto (R\$ bilhões) } \\
\cline { 2 - 7 } & \multicolumn{5}{|c|}{2010} \\
\cline { 2 - 7 } & SCN-2010 & Part.\% & SCN-2000 & Part.\% & Diferença \\
\hline Total & 3304 & $100 \%$ & 3227 & $100 \%$ & $\ldots$ \\
\hline Agropecuária & 160 & $4,90 \%$ & 171 & 5,3 & $-0,40 \%$ \\
\hline Indústria & 904 & $27,40 \%$ & 906 & $28,10 \%$ & $-0,70 \%$ \\
\hline Indústria extrativa & 110 & $3,30 \%$ & 96 & $3,00 \%$ & $0,30 \%$ \\
\hline Indústria de transformação & 494 & $15,00 \%$ & 524 & $16,20 \%$ & $-1,20 \%$ \\
\hline
\end{tabular}

$\overline{196}$ No SCN-2000 era utilizada a CNAE 1.0. Houve ampliação do detalhamento das atividades de serviços, maior ênfase em atividades ligadas ao meio ambiente; e maior detalhamento dos serviços de informação e atividades ligadas à propriedade intelectual. 


\begin{tabular}{|l|r|r|r|r|r|}
\hline $\begin{array}{l}\text { Energia Elétrica, gás, água, esgoto e } \\
\text { limpeza urbana }\end{array}$ & 93 & $2,80 \%$ & 104 & $3,20 \%$ & $-0,40 \%$ \\
\hline Construção Civil & 207 & $6,30 \%$ & 182 & $5,70 \%$ & $0,60 \%$ \\
\hline Serviços & 2240 & $67,80 \%$ & 2150 & $66,60 \%$ & $1,20 \%$ \\
\hline Comércio & 416 & $12,60 \%$ & 404 & $12,50 \%$ & $0,10 \%$ \\
\hline Transporte Armazenagem e Correio & 142 & $4,30 \%$ & 162 & $5,00 \%$ & $-0,70 \%$ \\
\hline Serviços de informação & 127 & $3,80 \%$ & 104 & $3,20 \%$ & $0,60 \%$ \\
\hline $\begin{array}{l}\text { Intermediação financeira, seguros } \\
\text { e previdência complementar }\end{array}$ & 225 & $6,80 \%$ & 242 & $7,50 \%$ & $-0,70 \%$ \\
\hline Atividades imobiliárias & 274 & $8,30 \%$ & 253 & $7,80 \%$ & $0,50 \%$ \\
\hline Outros serviços & 518 & $15,70 \%$ & 462 & $14,30 \%$ & $1,40 \%$ \\
\hline $\begin{array}{l}\text { Administração, saúde e educação } \\
\text { públicas e seguridade social }\end{array}$ & 538 & $16,30 \%$ & 523 & $16,20 \%$ & $0,10 \%$ \\
\hline Fonte: SCCN/IG & & & & & \\
\hline
\end{tabular}

Fonte: SCN/IBGE. Elaboração própria.

A modificação conceitual teve impacto significativo sobre a FBCF, com aumento da participação no PIB. O cotejo das séries do SCN-2000 e 2010 permite a observação de aumento em nível e como proporção do PIB, de maneira monotônica, o que se justifica pela reclassificação de gastos de consumo intermediário agora como investimento na nova série.

Gráfico 25. Participação da Formação Bruta de Capital Fixo no PIB segundo o SCN2000 e o SCN-2010, 2000-2011.

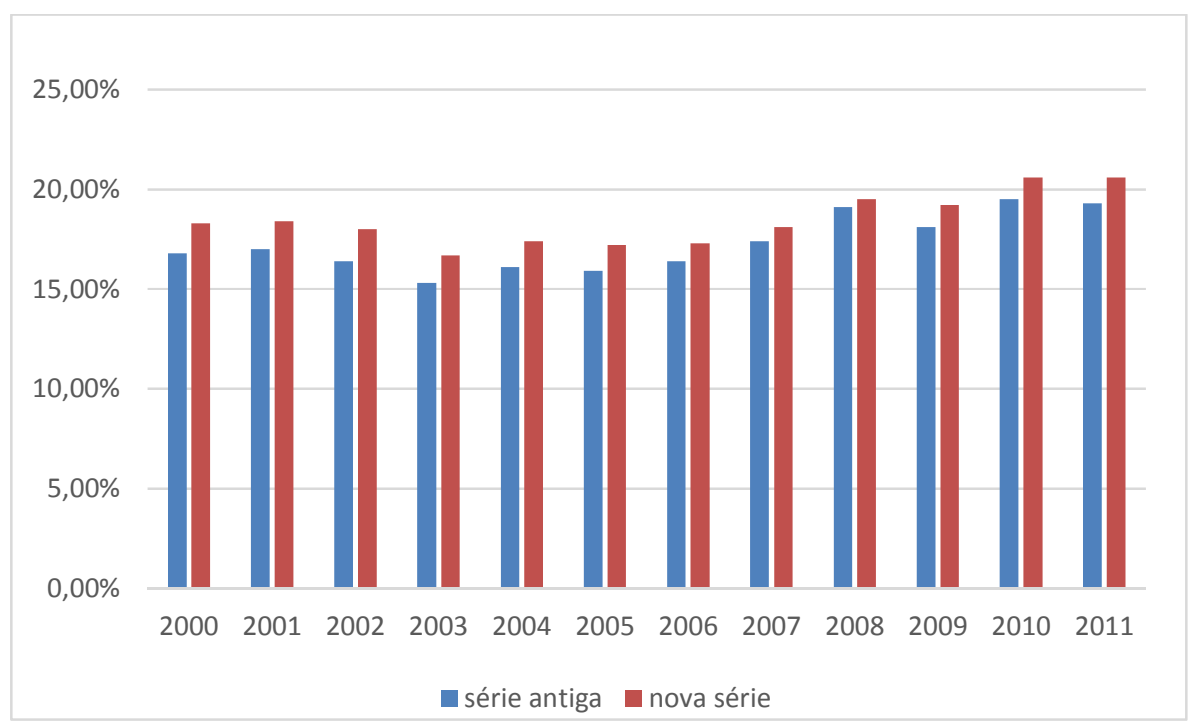

Fonte: SCN/IBGE. Elaboração própria. 


\section{Anexo}

Tabela 6. Classificação setorial por intensidade tecnológica.

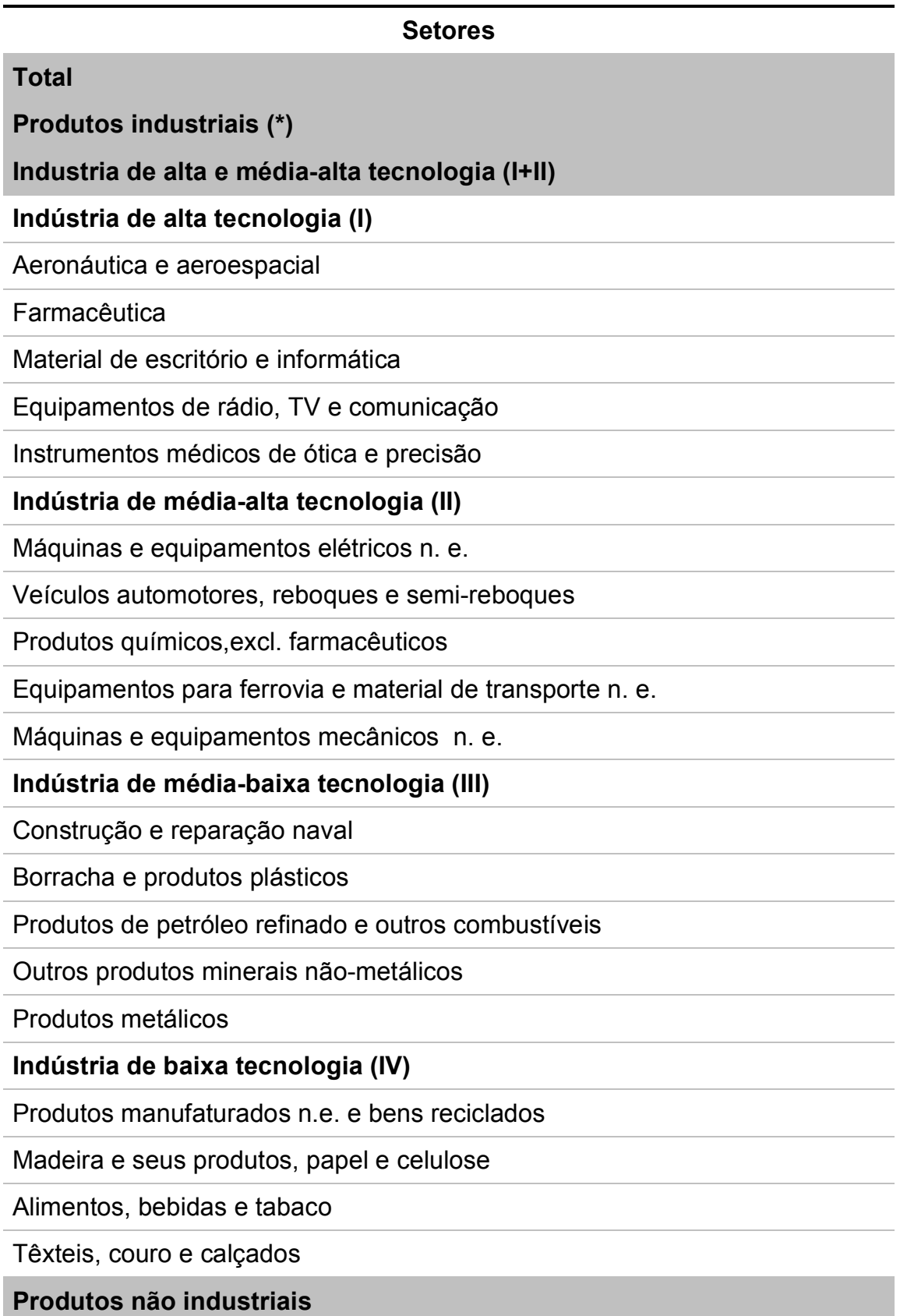

$\left(^{*}\right)$ Classificação extraída de: OECD, Directorate for Science, Technology and Industry, STAN Indicators, 2003.

Obs.: n. e. = não especificados nem compreendidos em outra categoria 


\section{Referências bibliográficas}

ABIMAQ. Associação Brasileira da Indústria de Máquinas e Equipamentos. Indicadores conjunturais. Dezembro, 2014.

ALBUQUERQUE, E. M. National systems of innovation and non-OECD countries: Notes about a rudimentary and tentative typology. Brazilian Journal of Political Economy, v. 19, n. 4 (76), October-december, 1999.

ALBUQUERQUE, E. M. Inadequacy of technology and innovation systems at the periphery. Cambridge Journal of Economics, 31(5): 669-690, 2007.

AMADO, A. M. O Real e o Monetário em Economia: Traços Ortodoxos e Heterodoxos do Pensamento Econômico. In: SILVA, M. L. (Org.). Moeda e produçãa: teorias comparadas. Brasília: Editora Universidade de Brasília, 1992.

AMADO, A. M. Limites monetários ao crescimento: Keynes e a não-neutralidade da moeda. Ensaios FEE, vol. 21, 2000.

AMADO, A. M.; CARUSO, P. Liberalização, vulnerabilidade financeira e instabilidade: algumas considerações sobre a economia brasileira. Economia e Sociedade, Campinas, v. 20, n. 3 (43), p. 475-499, dez. 2011.

AMADO, A. M.; RESENDE, M. F. C. Liquidez internacional e ciclo reflexo: algumas observações para a América Latina. Revista de Economia Política, vol. 27, nº 1 (105), janeiro-março, 2007.

AMItRANO, C. R.; CINTRA, M. A. M.; SQUEFF, G. C.; VASCONCELOS, L. F. Produção, emprego e investimento: crescimento e mudança estrutural no Brasil. In: MONASTERIO, L. M.; NERI, M. C.; SOARES, S. S. D. (org.) Brasil em desenvolvimento 2014: estado, planejamento e políticas públicas. Vol. 1. Brasília: Ipea, 2014.

ARAUJO, R. A.; LIMA, G. T. A Structural Economic Dynamic Approach to Balance of Payments Constrained Growth. Cambridge Journal of Economics, 31(5), 755 - 774, 2007.

BACHA, E.; BOLLE, M. B. (org.) O futuro da indústria no Brasil: desindustrialização em debate. São Paulo: Civilização Brasileira, 2013.

BALDWIN, R. E. The Case Against Infant-Industry Tariff Protection. Journal of Political Economy, 77 (3), p. 295-305, 1969. 
BARBOSA, N.; SOUZA, J. A. P. A Inflexão do Governo Lula: Política Econômica, Crescimento e Distribuição de Renda. In: SADER, E.; GARCIA, M. A. (orgs.) Brasil: entre o Passado e o Futuro. São Paulo: Fundação Perseu Abramo e Editora Boitempo, 2010.

BEKERMAN, M.; DULCICH, F. The international trade position of Argentina. Towards a process of export diversification? Cepal Review, 110, Aug. 2013.

BELLOFIORE, R. Marx and the Macro-monetary Foundation of Microeconomics. In: BELLOFIORE, R.; TAYLOR, N. The constitution of Capital. Gordonsville: Palgrave, 2004.

BELLOFIORE, R. The Socialization of Investment, from Keynes to Minsky and beyond. Levy Economics Institute Working Paper, No. 822, 2014.

BIELSCHOWSKY, R. Pensamento econômico brasileiro: o ciclo ideológico do desenvolvimentismo. Rio de Janeiro: IPEA, 1988.

BIELSCHOWSKY, R. Cinqüenta anos de pensamento na CEPAL - uma resenha. In: BIELSCHOWSKY, R. (Org.) Cinqüenta anos de pensamento na CEPAL. 2 vol. Rio de Janeiro: Record, 2000.

BIELSCHOWSKY, R. (Org.). Sesenta años de la CEPAL: textos seleccionados del decenio 1998-2008. Buenos Aires: Siglo XXI, 2010.

BIELSCHOWSKY, R. Estratégia de desenvolvimento e as três frentes de expansão no Brasil: um desenho conceitual. Economia e Sociedade, Campinas, v. 21, Número Especial, p. 729-747, dez. 2012.

BIELSCHOWSKY, R.; ABICALIL, M. T.; OLIVEIRA, J. C.; SOARES, S.; WOHLERS, M. Formação de capital no ambiente das reformas econômicas brasileiras dos anos 1990: uma abordagem setorial. In: BAUMANN, R. (org.) Brasil: uma década em transição. Rio de Janeiro: Campus, 2000.

BLANKENBURG, S., PALMA, J. G.; TREGENNA, F. Structuralism. In: DURLAUF, S.; BLUME, L. E (Eds.). The New Palgrave Dictionary of Economics. Second Edition. Palgrave Macmillan, 2008. Disponível em: http://www.dictionaryofeconomics.com/article?id=pde2008_S000312.

BLOCK, F.; KELLER, M. R. (eds.) State of innovation: The US Government's role in technology development. Boulder, CO: Paradigm Publishers, 2011.

BOFFO, M. Analytical Marxism. In: FINE, B.; SAAD FILHO, A.; BOFFO, M. The Elgar Companion to Marxist Economics. Cheltenham, UK; Northampton, MA, USA: Edward Elgar, 2012. 
BOIANOVSKY, M. A View from the Tropics: Celso Furtado and the Theory of Economic Development in the 1950s. History of Political Economy, v. 42, p. 221-266, 2010.

BRASIL. Ministério do Desenvolvimento, Indústria e Comércio Exterior. Plano Brasil Maior - Apresentação. 2012. Disponível em: http://www.brasilmaior.mdic.gov.br.

BRAVERMAN, H. Labor and monopoly capital: the degradation of work in the twentieth century. New York: Monthly Review Press, 1974 [1998].

BRESSER-PEREIRA, L. C.; LIMA, G. T. The irreductibility of macro to microeconomics: a methodological approach. Revista de Economia Política, vol. 16, no 2 (62), pp. 16-39, abril-junho, 1996.

BRESSER-PEREIRA, L. C. The Dutch disease and its neutralization: A Ricardian approach. Revista de Economia Política, vol. 28, $\mathrm{n}^{\mathrm{o}} 1$ (109), pp. 47-71, January$\operatorname{March} / 2008$.

BRESSER-PEREIRA， L. C.; GALA， P. Macroeconomia estruturalista do desenvolvimento. Revista de Economia Política, vol. 30, nº 4 (120), pp. 663-686, outubro-dezembro/2010.

BRESSER-PEREIRA, L. C. Uma escola de pensamento keynesiano-estruturalista no Brasil? Revista de Economia Política, vol. 31, nº 2 (122), pp. 305-314, abril-junho/2011. BRESSER-PEREIRA, L. C. For a heterodox mainstream economics: an academic manifesto. Journal of Post-Keynesian Economics, vol. 35 (1), p. 3-20, 2012.

BRESSER-PEREIRA, L. C. A construção política do Brasil: sociedade, economia e Estado desde a Independência. São Paulo: Editora 34, 2015.

BRUNHOFF, S. A moeda em Marx. Rio de Janeiro: Paz e Terra, 1978.

BRUNHOFF, S. Estado e capital: uma análise da política econômica. Rio de janeiro: Forense, 1985.

BRUNHOFF, S.; CHESNAIS, F.; DUMÉNIL, G.; HUSSON, M.; LEVY, D. A finança capitalista. São Paulo: Alameda, 2010.

CABELLO, A. F. The Firm: the Role of Hierarchy and Market in Coasean and Marxist Tradition. In: 18th European Society for the History of Economic Thought Annual Conference, 2014, Lausanne, Suíça. Book of abstracts. Lausanne: ESHET, 2014. v. 1. p. 37-37.

CAMPOS NETO, C. A. S.; POMPERMAYER, F. M. Ressurgimento da Indústria Naval no Brasil (2000-2013). Brasília: Ipea, 2014. 
CARNEIRO, R. Velhos e Novos Desenvolvimentismos, Economia e Sociedade, v. 21, Número especial, p. 749-778, dez. 2012.

CARVAlHO, F. J. C. Mr. Keynes and the Post Keynesians. Aldershot: Edward Elgar, 1992.

CEPAL. Comissão Econômica para a América Latina e o Caribe. Introdução à técnica de planejamento [1955]. In: In: BIELSCHOWSKY, R. (Org.) Cinqüenta anos de pensamento na CEPAL. 2 vol. Rio de Janeiro: Record, 2000.

CEPAL. Comissão Econômica para a América Latina e o Caribe. Transformação produtiva com equidade: a tarefa prioritária do desenvolvimento da América Latina e do Caribe nos anos 1990 [1990]. In: In: BIELSCHOWSKY, R. (Org.) Cinqüenta anos de pensamento na CEPAL. 2 vol. Rio de Janeiro: Record, 2000.

CEPAL. Comissão Econômica para a América Latina e o Caribe. Progreso técnico y cambio estructural en América Latina. Documentos de proyectos, nº 136 (LC/W.136). Santiago de Chile: CEPAL, 2007.

CHANDLER, A. D. What is a firm? A historical perspective. European Economic Review, vol. 36, 1-2, p. 483-492, 1992.

CHANG, H.-J. Chutando a escada: a estratégia do desenvolvimento em perspectiva histórica. São Paulo: Unesp, 2004.

CHANG, H.-J.; LIN, J. Y. Should industrial policy in developing countries conform to comparative advantage or defy it? - A debate between Justin Lin and Ha-Joon Chang. Development Policy Review, vol. 27, no. 5, 2009.

CHESNAIS, F. A proeminência da finança no seio do "capital em geral", o capital fictício e o movimento contemporâneo de mundialização do capital. In: BRUNHOFF, S.; CHESNAIS, F.; DUMÉNIL, G.; HUSSON, M.; LEVY, D. A finança capitalista. São Paulo: Alameda, 2010.

CHICK, V. Macroeconomics after Keynes. MIT Press: Cambridge, 1983.

CHICK, V. Theory, method and mode of thought in Keynes's General Theory. Journal of Economic Methodology, 10 (3):307-327, 2003.

CIMOLI, M.; DOSI, G.; NELSON, R.; STIGLITZ, J. E. Institutions and policies shaping industrial development. In: CIMOLI, M.; DOSI, G.; STIGLITZ, J. E. Industrial Policy and Development: The Political Economy of Capabilities Accumulation. New York: Oxford University Press, 2009. 
CIMOLI, M.; PEREIRA, W.; PORCILE, G.; SCATOLIN, F. Structural change, technology, and economic growth: Brazil and the CIBS in a comparative perspective. Economic Change and Restructuring, 44:25-47, 2011.

CNI. Confederação Nacional da Indústria. Propostas da indústria para as eleições 2014. Brasília: CNI, 2014.

CORIAT, B.; WEINSTEIN, O. Les théories de la firme entre "contrats" et "compétences". Revue d'économie industrielle, 129-130, 1er et 2e trimestres, 2010.

CROTTY, J. Rethinking Marxian investment theory: Keynes-Minsky instability, competitive regime shifts and coerced investment. Review of Radical Political Economics, vol. 25, no. 1, 1-26, 1993.

CROTTY, J. Was Keynes a Corporatist? Keynes's Radical Views on Industrial Policy and Macro Policy in the 1920s. Journal of Economic Issues, Fall, Vol. 33 Issue 3, p. $555,1999$.

CROTTY, J. The neoliberal paradox: The impact of destructive product market competition and 'modern' financial markets on nonfinancial corporation performance in the neoliberal era. In: EPSTEIN, G. A. Financialization and the World Economy. Cheltenham, UK; Northhampton, USA: Edward Elgar, 2005.

DABLA-NORRIS, E.; KOCHHAR, K. RICKA, F.; SUPHAPHIPHAT, N.; TSOUNTA, E. Causes and Consequences of Income Inequality: A Global Perspective. IMF Discussion Note, Jun. 2015.

DAVIDSON, P. Money and the real world. New York: Wiley, 1972.

DAVIDSON, P. The Neoclassical vs. Post Keynesian View of Government. In: DAVIDSON, P. Controversies in Post Keynesian Economics. Aldershot, UK Brookfield, US: Edward Elgar, 1991.

DE NEGRI, F.; CAVALCANTE, L. R. (orgs.) Produtividade no Brasil: desempenho e determinantes. Vol. 1. Brasília: IPEA, 2014.

DE NEGRI, F; CAVAlCANTE, L. R. Análise dos dados da Pintec 2011. Nota Técnica IPEA. Brasília; Rio de Janeiro: IPEA, 2013.

DINIZ, E.; BOSCHI, R. R. A difícil rota do desenvolvimento: empresários e a agenda pós-neoliberal. Belo Horizonte: Editora UFMG; Rio de Janeiro: IUPERJ, 2007.

DOS SANTOS, P. L. Demand, Production, and the Determinants of Distribution: A Caveat on "Wage-Led Growth". Political Economy Research Institute Working Paper (323), 2013. 
DOSI, G.; FREEMAN, C.; NELSON, R.; SILVERBERG, G.; SOETE, L. (eds). Technical change and economic theory. London: Pinter Publishers, 1988.

DOSI, G.; SOETE, L.; PAVITT, K. The economics of technical change and international trade. New York: New York Univ. Press, 1990.

DOW, S. The methodology of macroeconomic thought: A conceptual analysis of schools of thought in economics. 2nd ed. Cheltenham \& Northampton: Edward Elgar, 1996.

DUARTE, P. G.; LIMA, G. T. Privileging micro over macro? A history of conflicting positions. In: DUARTE, P. G.; LIMA, G. T. (Eds.). Microfoundations reconsidered: The relationship of Micro and Macroeconomics in Historical Perspective. Cheltenham: Edward Elgar, 2012.

DUNN, S. P. A Post Keynesian approach to the theory of the firm. In: DOW, S. C.; HILLARD, J. Post Keynesian econometrics, microeconomics and the theory of the firm: Beyond Keynes, Volume One. Cheltenham, UK; Northampton, MA, USA: Edward Elgar, 2002.

EICHNER, A. The Megacorp and Oligopoly, Micro Foundations of Macro Dynamics. New York: Cambridge University Press, 1976.

EPSTEIN, G. A. Introduction: Financialization and the World Economy. In: EPSTEIN, G. A. Financialization and the World Economy. Cheltenham, UK; Northhampton, USA: Edward Elgar, 2005.

FAGERBERG, J. Technology and international differences in growth rates. Journal of Economic Literature, Nashville, v. 32, n. 4, p. 1147-1175, September, 1994.

FAGERBERG, J.; SRHOLEC, M. Structural Changes in International Trade: Cause, Impact and Response. Revue économique, vol. 55, N 6, p. 1071-1098, novembre 2004. FAGERBERG, J.; SRHOLEC, M.; KNELL, M. The competitiveness of nations: Why some countries prosper while others fall behind. World Development, Vol. 35, No. 10, pp. 1595-1620, 2007.

FAGERBERG, J.; SRHOLEC, M.; VERSPAGEN, B. Innovation and Economic Development. In: HALL, B.; ROSENBERG, N. Handbook of the economics of innovation. North Holland, 2010.

FAJNZYLBER, F. La industrialización trunca de América Latina. México, D.F.: Editorial Nueva Imagen, 1983. 
FAJNZYLBER, F. Industrialização na América Latina: da caixa preta ao conjunto vazio [1990]. In: BIELSCHOWSKY, R. (org.). Sesenta años de la CEPAL: textos seleccionados del decenio 1998-2008. Buenos Aires: Siglo XXI, 2010.

FEIJÓ, C. A. Decisões Empresariais numa Economia Monetária de Produção: notas para uma teoria pós-keynesiana da firma. Revista de Economia Política, São Paulo, v. 13, n.jan-mar, p. 82-100, 1993.

FEIJÓ, C. A.; RAMOS, R. L. O. (Orgs.); LIMA, F. C. G. C.; BARBOSA FILHO, N. H.; PALIS, R. Contabilidade social: a nova referência das contas nacionais no Brasil. $4^{\mathrm{a}}$ ed. Rio de Janeiro: Elsevier, 2013.

FREEMAN, C. Technology and Economic Performance: Lessons from Japan. London: Pinter Publishers, 1987.

FUNCEX. Fundação Centro de Estudos do Comércio Exterior. Funcexdata. Funcex, 2015. Disponível em: http://www.funcexdata.com.br.

FURTADO, C. Formação econômica do Brasil. São Paulo: Companhia das Letras, 1959 [2007].

GALBRAITH, J. K. The new industrial state. Harmondsworth: Penguin, 1967 [1974].

GEREFFI, G.; KORZENIEWCZ, M. Commodity Chains and Global Capitalism. Westport: Greenwood Press, 1993.

GOBETTI, S. W.; AMADO, A. M. Ajuste Fiscal no Brasil: algumas considerações pós keynesianas. Revista de Economia Política, v. 31, p. 37-54, 2011.

GOLDSTEIN, J. P. Marxian Microfoundations: Contribution or Detour? Review of Radical Political Economics, 38: 569, 2006.

GONÇALVES, R. Desenvolvimento às avessas. Rio de Janeiro: LTC, 2013.

GOUVÊA, R.; LIMA, G. Structural Change, Balance-of-Payments Constraint and Economic Growth: Evidence from the Multisectoral Thirlwall's Law. Journal of Post Keynesian Economics, Vol. 33, Number 1, p. 169 - 204, Fall 2010.

GREENWALD, B. E.; STIGLITZ, J. E. Externalities in Economies with Imperfect Information and Incomplete Markets. The Quarterly Journal of Economics, Vol. 101, No. 2, pp. 229-264, May, 1986.

GREENWALD, B. E.; STIGLITZ, J. E. Industrial Policies, the Creation of a Learning Society, and Economic Development. In: In: STIGLITZ, J. E.; LIN, J. Y. The Industrial Policy Revolution I: The Role of Government beyond Ideology. London: Palgrave Macmillan, 2013. 
HALL, R. L.; HITCH, C.J. Price Theory and Business Behavior. Oxford Economic Papers, no. 2, 17, May 1939.

HARVEY, D. The limits to capital. Verso: London, New York, 1982 [2006].

HARVEY, D. A companion to Marx's Capital. London, New York: Verso, 2010. HAUSMANN, R.; HIDALGO, C. A.; BUSTOS, S.; COSCIA, M.; CHUNG, S.; JIMENEZ, J.; SIMOES, A.; YILDIRIM, M. A. A. The Atlas of Economic Complexity: Mapping Paths to Prosperity. Harvard: Center for International Development, 2011. HAUSMANN, R.; HWANG, J.; RODRIK, D. What you export matters. Journal of Economic Growth, 12, 1-25, 2007.

HODGSON, G. Evolutionary and competence-based theories of the firm. Journal of Economic Studies, Vol. 25 No. 1, 1998, pp. 25-56.

HOOVER, K. D. Microfoundational Programs. In: DUARTE, P. G.; LIMA, G. T. (Eds.). Microfoundations reconsidered: The relationship of Micro and Macroeconomics in Historical Perspective. Cheltenham: Edward Elgar, 2012.

HOWARD, M. C.; KING, J. E. Where Marx was right: Towards a more secure foundation for heterodox economics. Cambridge Journal of Economics, vol. 25(6), pages 785-807, November, 2001.

IBGE. Instituto Brasileiro de Geografia e Estatística. Pesquisa de Inovação nas Empresas Estatais Federais 2008. Rio de Janeiro: IBGE, 2011.

IBGE. Pesquisa Industrial Anual 2013. Rio de Janeiro: IBGE, 2015. Disponível em: www.ibge.gov.br.

IBGE. Sistema de Contas Nacionais. Rio de Janeiro: IBGE, 2015. Disponível em: Www.ibge.gov.br.

IMBS, J.; WACZIARG, R. Stages of diversification. American Economic Review, Vol. 93, $\mathrm{N}^{\circ} 1,2003$.

ITOH, M.; LAPAVITSAS, C. Political economy of money and finance. London: Macmillan, 1999.

JAUMotTe, F.; BUITRON, C. O. Power from the People. Finance \& Development, 52 (1), p. 29-31, 2015.

JAY, M. Marxism and totality. Berkeley and Los Angeles: University of California Press, 1984.

KALDOR, N. Causes of the Slow Rate of Economic Growth in the United Kingdom. In: KALDOR, N. Further Essays on Economic Theory. New York: Holmes \& Meier, 1966 [1978]. 
KALECKI, M. Political Aspects of Full Employment. The Political Quarterly, Volume 14, Issue 4, pages 322-330, October 1943.

KALECKI, M. The Principle of Increasing Risk. Economica, New Series, Vol. 4, No. 16, pp. 440-447, Nov., 1937.

KATKALO, V. S.; PITELIS, C. N.; TEECE, D. J. Introduction: On the nature and scope of dynamic capabilities. Industrial and Corporate Change, Volume 19, Number 4, pp. 1175-1186, 2010.

KEYNES, J. M. Am I a Liberal [1925]. In: KEYNES, J. M. The Collected Writings of John Maynard Keynes, Vol. IX. Cambridge: Macmillan, 1972.

KEYNES, J. M. The End of Laissez-Faire [1926]. In: KEYNES, J. M. The Collected Writings of John Maynard Keynes, Vol. IX. Cambridge: Macmillan, 1972.

KEYNES, J. M. Liberalism and Industry [1927]. In: KEYNES, J. M. The Collected Writings of JMK, Vol. XIX. Cambridge: Macmillan, 1981.

KEYNES, J. M. The distinction between a co-operative economy and an entrepreneur economy [1933]. In: KEYNES, J. M. The Collected Writings of JMK, Vol. XXIX. Cambridge: Macmillan, 1973.

KEYNES, J. M. The general theory of employment, interest and money. Harcourt: New York, 1964 [1936].

KEYNES, J. M. The General Theory of Employment [1937]. In: KEYNES, J. M. The Collected Writings of JMK, Vol. XIV. Cambridge: Macmillan, 1987.

KING, J. E. Post Keynesian economics. In: The New Palgrave Dictionary of Economics. Second Edition. Eds. Steven N. Durlauf and Lawrence E. Blume. Palgrave Macmillan, 2008.

KIRMAN, A. P. Whom or what does the representative individual represent? Journal of Economic Perspectives, 6: 117-136, 1992.

KREGEL, J. Rational spirits and the post-keynesian macrotheory of macroeconomics. De Economist, 135 (4), 520-32.

KRUEGER, A. O. The Political Economy of the Rent-Seeking Society. American Economic Review, vol. 64, issue 3, pages 291-303, 1974.

KUPFER, D.; LAPLANE, M. F. Perspectivas do investimento no Brasil: síntese final. Mimeo. 2010. Disponível em: http://www.ie.ufrj.br/projetopib/.

KUPFER, D.; FERRAZ, J. C.; MARQUES, F. S. The return of industrial policy in Brazil. In: STIGlitZ, J. E.; LIN, J. Y. The Industrial Policy Revolution I: The Role of Government beyond Ideology. London: Palgrave Macmillan, 2013. 
LAFAY, G. Avantage comparatif et competitivité. Economie prospective internationale, Revue du CEPII, n. 29, 1987.

LALL, S. The technological structure and performance of developing country manufactured exports, 1985-98. Oxford Development Studies, 28, pp. 337-369, 2000.

LALL, S.; WEISS, J.; ZHANG, J. The "Sophistication" of Exports: A New Trade Measure. World Development, Vol. 34, No. 2, pp. 222-237, 2006.

LAPLANE, M. F. Inovação, competitividade e reindustrialização no Brasil pós-crise. In: BARBOSA, N.; MARCONI, N.; PINHEIRO, M. C.; CARVALHO, L. Indústria e desenvolvimento produtivo no Brasil. Rio de Janeiro: Elsevier, FGV, 2015.

LAPLANE, M. F. Six decades of mission-oriented finance for industrialisation, technical change and innovation in Brazil. In: MAZZUCATO, M.; PENNA, C. C. R. Missionoriented finance for innovation: New ideas for investment-led growth. London: Rowman \& Littlefield, 2015b.

LAPLANE, M. F.; SARTI, F. Prometeu Acorrentado: O Brasil na Indústria Mundial no Início do Século XXI. In: CARNEIRO, R. (Org.) A Supremacia dos Mercados e a Política Econômica do Governo Lula. São Paulo: Editora UNESP, 2006.

LAVOIE, M. Post-Keynesian economics: New foundations. Cheltenham: Edward Elgar, 2014.

LAZONICK, W.; O'SULLIVAN, M. Organization, Finance and International Competition. Industrial and Corporate Change, 5 (1), p. 1-49, 1996.

LAZONICK, W.; O'SULLIVAN, M. Maximizing shareholder value: a new ideology for corporate governance. Economy and Society, Volume 29, Issue 1, p. 13-35, 2000.

LEE, F. S. Post Keynesian Price Theory. Cambridge University Press, 1999.

LIN, J. Y. New structural economics: a framework for rethinking development. Washington: The World Bank, 2012.

LIN, J. Y.; MONGA, C. Comparative Advantage: The Silver Bullet of Industrial Policy. In: STIGLiTZ, J. E.; LIN, J. Y. The Industrial Policy Revolution I: The Role of Government beyond Ideology. London: Palgrave Macmillan, 2013.

LUCAS, R. Econometric Policy Evaluation: A Critique. In: K. BRUNNER; MELTZER, A. (eds.). The Phillips Curve and Labor Markets. Carnegie-Rochester Conference Series on Public Policy, Volume 1, pages 19-46, 1976.

LUKÁCS, G. Para uma ontologia do ser social I. São Paulo: Boitempo, 1984 [2012]. 
MALERBA, F. Sectoral systems: How and why innovation differs across sectors. In: FAGERBERG, J.; MOWERY, D.; NELSON, R. The Oxford handbook of innovation. Oxford University Press, 2005.

MARglin, S. A. What Do Bosses Do? Review of Radical Political Economics, 6, 2, p. 60-112, Summer 1974.

MARX, K. Grundrisse. São Paulo: Boitempo, 2011 [1857/58].

MARX, K. Results of the Immediate Process of Production [1864]. In: MARX, K. Capital. Vol. I. Middlesex, England: Penguin Books, 1867 [1976].

MARX, K. O Capital: crítica da economia política. Livro I. São Paulo: Boitempo, 2013 [1867].

MARX, K. O Capital: crítica da economia política. Livro II. São Paulo: Boitempo, 2014 [1885].

MARX, K. O Capital: crítica da economia política. Livro III. Rio de Janeiro: Civilização Brasileira, 1998 [1894].

MAYER, J.; BUTKEVICIUS, A.; KADRI, A.; PIZARRO, J. Dynamic products in world exports. Review of World Economics (Weltwirtschaftliches Archiv), Springer, vol. 139(4), pages 762-795, December, 2003.

MAZZUCATO, M. The Entrepreneurial State: Debunking Public vs. Private Sector Myths. London: Anthem Press, 2013.

MAZZUCATO, M. Beyond market failures: Shaping and creating markets for innovation-led growth. In: MAZZUCATO, M.; PENNA, C. C. R. Mission-oriented finance for innovation: New ideas for investment-led growth. London: Rowman \& Littlefield, 2015.

MEMEDOVIC, O.; IAPADRE, L. Structural change in the world economy: Main features and trends. Working paper, 24/2009. UNIDO, 2010.

MEI. Mobilização Empresarial pela Inovação. O estado da inovação no Brasil: a nova agenda da MEI para ampliar a inovação empresarial. Brasília: MEI, 2014.

MINSKY, H. P. John Maynard Keynes. New York; McGraw-Hill, 1975 [2008].

MINSKY, H. P. Can 'it' happen again? Essays on instability and finance. Armonk: M. E. Sharpe, 1982.

MINSKY, H. P. Stabilizing an Unstable Economy. New York: McGraw-Hill, 1986 [2008].

MITERHOF, M. T.; FERRAZ, J. C. MARQUES, F. S. BNDES: preenchendo lacunas, corrigindo falhas e induzindo externalidades. In: BARBOSA, N.; MARCONI, N.; 
PINHEIRO, M. C.; CARVALHO, L. Indústria e desenvolvimento produtivo no Brasil. Rio de Janeiro: Elsevier, FGV, 2015.

MOLLO, M. L. R. A concepção marxista de Estado: considerações sobre antigos debates com novas perspectivas. Economia, vol. 2, n. 2, jul/dez/2001.

MOLLO, M. L. R. Moeda, taxa de juros e preferência pela liquidez em Marx e Keynes. In: LIMA,G. T.; SICSÚ, J. (orgs.) Macroeconomia do emprego e da renda: Keynes e o keynesianismo. Barueri, SP: Manole, 2003.

MOLLO, M. L. R. Crédito, capital fictício, fragilidade financeira e crises: discussões teóricas, origens e formas de enfrentamento da crise atual. Economia e Sociedade, Campinas, v. 20, n. 3 (43), p. 449-474, dez. 2011.

MOLLO, M. L. R. A Supremacia da Finança e a Crise. Brazilian Keynesian Review, v. 1, n. 1, 2015.

MOLLO, M. L. R.; AMADO, A. M. O debate desenvolvimentista no Brasil: tomando partido. Economia \& Sociedade, v. 24, p. 1-28, 2015.

MOLLO, M. L. R.; AMADO, A. M. The 'developmentalism' debate in Brazil: some economic and political issues. Review of Keynesian Economics, Vol. 3 No. 1, pp. 7789 , Spring $2015 b$.

MOLlO, M. L. R.; FONSECA, P. C. D. Desenvolvimentismo e novodesenvolvimentismo: raízes teóricas e precisões conceituais. Revista de Economia Política, vol. 33, no 2 (131), pp. 222-239, abril-junho/2013.

MOLLO, M. L. R.; TEIXEIRA, J. Macrodynamic capability: concept and monetary and financial conditions. In: LEONCINI, R.; MONTRESOR, S. (Orgs.). Dynamic Capabilities Between Firm Organization and Local Systems of Production. Abingdon/New York: Routledge, 2008.

MORAIS, E.; SAAD FILHO, A. Da economia política à política econômica: o novodesenvolvimentismo e o governo Lula. Revista de Economia Política, vol. 31, no 4 (124), pp. 507-527, outubro-dezembro/2011

NEGOITA, M. To hide or not to hide? The Advanced Techonoly Program and the future of US civilian tecnology policy. In: BLOCK, F.; KELLER, M. R. (eds.) State of innovation: The US Government's role in technology development. Boulder, CO: Paradigm Publishers, 2011.

OCDE. Organização para a Cooperação e Desenvolvimento Econômico. Science, Technology and Industry Scoreboard 2009. Paris: OCDE, 2009. 
OCDE. Organização para a Cooperação e Desenvolvimento Econômico. Demand-side Innovation Policies. Paris: OCDE, 2011.

OMC; OCDE. Organização Mundial do Comércio; Organização para a Cooperação e Desenvolvimento Econômico. Measuring Trade in Value-Added: An OECD-WTO joint initiative. Disponível em: http://www.oecd.org/.

ORAIR, R. O. Notas sobre a trajetória do investimento público no Brasil. In: SQUEFF, G. C. (org.). Dinâmica macrossetorial brasileira. Brasília: Ipea, 2015.

OREIRO, J. L. C.; FEIJÓ, C. A. Desindustrialização: conceituação, causas, efeitos e o caso brasileiro. Revista de Economia Política, vol 30, no 2 (118), pp 219-232, abriljunho/2010.

PASTORE, A. C.; GAZZANO, M.; PINOTTI, M. C. Por que a produção industrial não cresce desde 2010? In: BACHA, E.; BOLLE, M. B. (org.) O futuro da indústria no Brasil: desindustrialização em debate. São Paulo: Civilização Brasileira, 2013.

PENROSE, E. The Theory of the Growth of the Firm. Oxford University Press: New York, 1959 [2009].

PERES, W.; PRIMI, A. Theory and practice of industrial policy. Evidence from the Latin American experience. CEPAL - Serie Desarrollo productivo, No 187, 2009.

POCHMANN, M. O mito da grande classe média: capitalismo e estrutura social. São Paulo: Boitempo Editorial, 2014.

POSSAS, M. L. Dinâmica e concorrência capitalista: uma interpretação a partir de Marx. São Paulo: Hucitec, 1989.

POSTONE, M. Rethinking Capital in light of the Grundrisse. In: MUSTO, M. (ed.) Karl Marx's Grundrisse: Foundations of the critique of political economy 150 years later. Routledge, 2008.

POSTONE, M. Time, labor, and social domination: A reinterpretation of Marx's critical theory. New York: Cambridge University Press, 1993.

POULANTZAS, N. A. O Estado, o poder, o socialismo. 4a Ed. Rio de janeiro: Graal, 2000 [1978].

PREBISCH, R. O desenvolvimento econômico da América Latina e alguns de seus problemas principais [1949]. In: BIELSCHOWSKY, R. (Org.) Cinqüenta anos de pensamento na CEPAL. 2 vol. Rio de Janeiro: Record, 2000.

PREBISCH, R. Estudo econômico da América Latina, 1949 [1951]. In: BIELSCHOWSKY, R. (Org.) Cinqüenta anos de pensamento na CEPAL. 2 vol. Rio de Janeiro: Record, 2000. 
PREBISCH, R. Problemas teóricos e práticos do crescimento econômico [1951b]. In: BIELSCHOWSKY, R. (Org.) Cinqüenta anos de pensamento na CEPAL. 2 vol. Rio de Janeiro: Record, 2000.

PRESSMAN, S. Microeconomics After Keynes: Post Keynesian economics and public policy. American Journal of Economics and Sociology, Vol. 70, No. 2, April, 2011.

RESENDE, M.F.C. O padrão dos ciclos de crescimento da economia brasileira: 19472003. Economia e Sociedade, Campinas, V.14, n.1(24), p. 25-55, Janeiro/Junho, 2005. RODRÍGUEZ, O. Teoria do subdesenvolvimento da CEPAL. Rio de janeiro: Forense Universitária, 1981.

RODRÍGUEZ, O. Prebisch: actualidad de sus ideas básicas. Revista de la CEPAL, 75, diciembre 2001.

RODRÍGUEZ, O. O estruturalismo latino-americano. Rio de Janeiro: Civilização Brasileira, 2009.

RODRIK, D. Políticas de diversificação econômica. Revista da CEPAL, número especial em português, 2010.

ROSDOLSKY, R. Gênese e estrutura de O Capital de Karl Marx. Rio de Janeiro: Eduerj, Contraponto, 2001.

SAAD FILHO, A. The Value of Marx. London and New York: Routledge, 2002.

SADER, E. (org.) 10 anos de governos pós-neoliberais no Brasil: Lula e Dilma. São Paulo: Boitempo; Rio de Janeiro: FLACSO Brasil; 2013.

SANTIAGO, S. Q.; COSTA, D.; AMADO, A. M. Estado e vulnerabilidade externa em países periféricos: algumas considerações sobre a América Latina e Ásia. In: XIV ENCONTRO NACIONAL DE ECONOMIA POLÍTICA, 2009, São Paulo. Anais... São Paulo, 2009.

SARTI, F. Padrão de crescimento e desenvolvimento industrial. In: BARBOSA, N.; MARCONI, N.; PINHEIRO, M. C.; CARVALHO, L. Indústria e desenvolvimento produtivo no Brasil. Rio de Janeiro: Elsevier, FGV, 2015.

SARTI, F.; HIRATUKA, C. Perspectivas do investimento na indústria. Rio de Janeiro: Synergia: UFRJ, Instituto de Economia; Campinas: UNICAMP, Instituto de Economia, 2010.

SCREPANTI, E.; ZAMAGNI, S. An outline of the history of economic thought. 2nd edition. Oxford: Oxford University Press, 2005.

SECEX. Secretaria de Comércio Exterior. Estatísticas de comércio exterior. Secex, 2015. Disponível em: www.mdic.gov.br. 
SHACKLE, G. L. S. Expectation, enterprise and profit: The theory of the firm. London: George Allen \& Unwin, 1970.

SHAPIRO, N. The Function of Firms: Alternative Views. In: ARESTIS, P. (ed.) Microeconomics, macroeconomics and economic policy: essays in honour of Malcolm Sawyer. London: Palgrave Macmillan, 2011.

SIMON, H. A. Models of Man: Social and Rational; Mathematical Essays on Rational Human Behavior in a Social Setting. New York: Wiley, 1957.

SIMON, H. A. Organizations and Markets. Journal of Economic Perspectives. Vol. 5, No. 2, pp. 25-44, Spring, 1991.

SMITH, A. An Inquiry into the Nature and Causes of the Wealth of Nations. Chicago: Encyclopaedia Britannica, 1776 [1994].

SOARES, C.; TEIXEIRA, J. R. 2011. Uma Abordagem Econométrica Do Processo de Desindustrialização No Caso Brasileiro: Elementos Para O Debate. Anais do XXXVIII Encontro Nacional de Economia, ANPEC, 2011.

SOUZA, F. E. P. Por que a indústria parou? In: BARBOSA, N.; MARCONI, N.; PINHEIRO, M. C.; CARVALHO, L. Indústria e desenvolvimento produtivo no Brasil. Rio de Janeiro: Elsevier, FGV, 2015.

SQUEFF, G. C. Desindustrialização: luzes e sombras no debate brasileiro. Texto para discussão IPEA, 1747, junho 2012.

SQUEFF, G. C. Rigidez Produtiva e Importações no Brasil: 1995-2009. In: SQUEFF, G. C. (org.). Dinâmica macrossetorial brasileira. Brasília: Ipea, 2015.

STEINDL, J. Maturity and stagnation in American capitalism. New York: Monthly Review Press, 1952 [1976].

STIGLITZ, J. E. Is there a Post-Washington Consensus Consensus? In: SERRA, N.; STIGLITZ, J. E. The Washington Consensus reconsidered: Towards a new global governance. Oxford: Oxford University Press, 2008.

STIGLITZ, J. E.; GREENWALD, B. E. Creating a learning society. New York: Columbia University Press, 2014.

STIGLITZ, J. E.; LIN, J. Y.; MONGA, C. Introduction: The Rejuvenation of Industrial Policy. In: STIGLITZ, J. E.; LIN, J. Y. The Industrial Policy Revolution I: The Role of Government beyond Ideology. London: Palgrave Macmillan, 2013. 
STURGEON, T. J.; MEMEDOVIC, O. Mapping Global Value Chains: Intermediate Goods Trade and Structural Change in the World Economy. Working Paper, 05/2010. Vienna: UNIDO, 2011.

TAUILE, J. R. Para (re)construir o Brasil contemporâneo: trabalho, tecnologia e acumulação. Rio de Janeiro: Contraponto, 2001.

THIRLWALL, A. P. The balance-of-payments constraint as an explanation of international growth rates differences. Banca Nazionale del Lavoro Quarterly Review, March, 45-53, 1979.

TREGENNA, F. Characterising deindustrialisation: An analysis of changes in manufacturing employment and output internationally. Cambridge Journal of Economics, Vol. 33, pp. 433-66, 2009.

TREGENNA, F. What does the services sector mean in Marxian terms? Review of Political Economy, vol. 23, no. 2, p. 281-98, 2011.

TREGENNA, F. The specificity of manufacturing in Marx's economic thought. The European Journal of the History of Economic Thought, Volume 20, Issue 4, 2013.

TREGENNA, F. A new theoretical analysis of deindustrialisation. Cambridge Journal of Economics, 38, 1373-1390, 2014.

UNIDO. United Nations Industrial Development Organization. Industrial Development Report 2013. Vienna: UNIDO, 2013.

UNIDO. United Nations Industrial Development Organization. 21st century manufacturing. Vienna: UNIDO, 2013b.

UNIDO. United Nations Industrial Development Organization. Statistical databases. Vienna: UNIDO, 2015. Disponível em: http://www.unido.org/.

URRACA-RUIZ, A.; BRITTO, J.; SOUZA, K. S. G. Qualificando o caráter regressivo da especialização industrial do Brasil. Econômica (Niterói), v. 15, p. 120-147, 2013.

WADE. R. H. Governing the market: economic theory and the role of government in East Asian industrialization. Princeton: Princeton University Press, 1990.

WADE. R. H. The paradox of US industrial policy: The developmental state in disguise. In: SALAZAR-XIRINACHS, J. M.; NÜBLER, I.; KOZUL-WRIGHT, R. (eds.). Transforming economies: Making industrial policy work for growth, jobs and development. Geneva: International Labour Office - ILO, 2014.

WEINTRAUB, S. A Macroeconomic Approach to the Theory of Wages. The American Economic Review, Vol. 46, No. 5, Dec. 1956. 
WILliamsON, O. E. The Economic Institutions of Capitalism: Firms, Markets, Relational Contracting, London: Macmillan, 1985.

WILLIAMSON, O. E. The Theory of the Firm as Governance Structure: From Choice to Contract. Journal of Economic Perspectives, 16(3), p. 171-95, 2002. 